Universidade de Brasília - UnB

Instituto de Ciências Sociais

Departamento de Sociologia - SOL Programa de Pós-Graduação em

Sociologia Tese de Doutorado em Sociologia

\title{
O Sul Global e a Difusão das Transferências Diretas de Renda: as mediações de Brasil e Î́ndia.
}

\section{Rogério Gimenes Giugliano}

\author{
Brasília - DF
}

Novembro de 2014 
Universidade de Brasília - UnB

Instituto de Ciências Sociais Departamento de Sociologia - SOL

Programa de Pós-Graduação em Sociologia

Tese de Doutorado em Sociologia

DOUTORADO EM SOCIOLOGIA

O Sul Global e a Difusão das Transferências Diretas de Renda: as mediações de Brasil e Índia.

\section{Rogério Gimenes Giugliano}

Tese apresentada ao Programa de Pós- Graduação em Sociologia, do Departamento de Sociologia, do Instituto de Ciências Sociais, da Universidade de Brasília, como requisito parcial para obtenção do título de Doutor em Sociologia.

Orientador: Prof. Dr. Marcelo Carvalho Rosa 


\section{Tese de Doutorado}

Titulo: O Sul Global e a Difusão das Transferências Diretas de Renda: as mediações de Brasil e Índia

Área de Concentração: Sociedade e Transformação

Linha de Pesquisa: Política, Valores, Religião e Sociedade.

Autor

Rogério Gimenes Giugliano

Orientador

Dr. Marcelo Carvalho Rosa

\section{BANCA EXAMINADORA}

Prof. Dr. Marcelo Carvalho Rosa - Presidente - Orientador (UnB/PPGSol)

Profa. Dr. Marcela Rosales - Membro Externo (CEA/UNC)

Prof. Dr. Marcos Costa Lima - Membro Externo (UFPE)

Prof. Dr. Sérgio Barreira De Faria Tavolaro - (Sol/UnB)

Prof. Dr. Fabrício Monteiro Neves - (Sol/UnB) 


\section{Agradecimentos}

Trabalho de pesquisa apoiado pelo CNPQ e CAPES.

Agradeço o apoio aos muitos amigos, colegas e familiares que colaboram e apoiaram este grande esforço. 


\section{Resumo:}

Esta tese descreve o resultado de pesquisa realizada entre os anos de 2012 e 2013 no Brasil e Índia. Trata-se de uma investigação de caráter sociológico que se debruça sobre o fenômeno contemporâneo do desenvolvimento.

O foco de análise é a difusão das Transferências Diretas de Renda (TDR) como estratégia de proteção social e combate à pobreza, processo iniciado em meados da década de 1990 e ainda em curso até os dias atuais.

Palavras chave: Desenvolvimento, Sul Global, Pobreza, Transferências Diretas de Renda 


\section{Abstract}

This thesis describes the results of research conducted between the years 2012 and 2013 in Brazil and India. This sociological investigation focuses on the contemporary phenomenon of development.

The main point of analysis is the diffusion of Conditional Cash Transfers (DCT) as means of social protection and poverty reduction. Process initiated in the mid -1990 s and continuing to the present day.

Keywords: Development, Global South, Poverty, And Conditional Cash Transfers 


\section{Sumário}

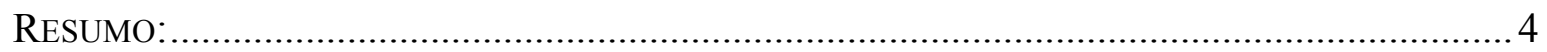

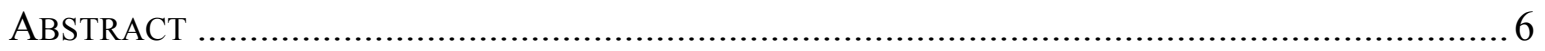

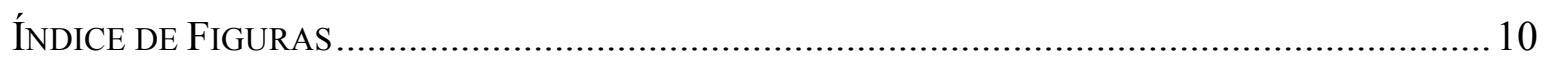

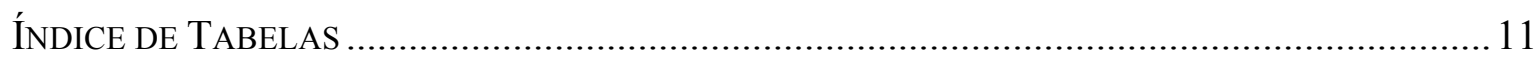

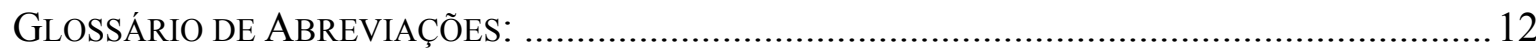

AGRADECIMENTO E ALGUMAS NOTAS PESSOAIS SOBRE A CARTOGRAFIA DESORDENADA DE UM DOUTORADO.

INTRODUÇÃO: Do PROJETO DO DESENVOLVIMENTO AS POLÍTICAS DE TRANSFERÊNCIA DE

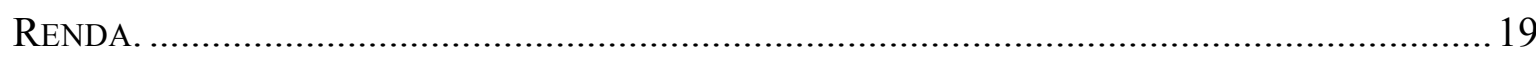

O norte global e as Transferências Diretas de Renda ..................................................... 21

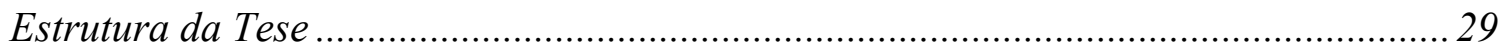

\section{PARTE I - ABORDAGEM AO OBJETO: OPÇÕES METODOLÓGICAS,}

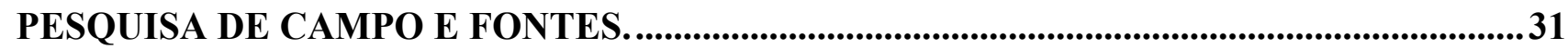

CAPÍTULO 1 - EsCOLHAS METODOLÓGICAS E NOTAS SOBRE O TRABALHO DE CAMPO ............32

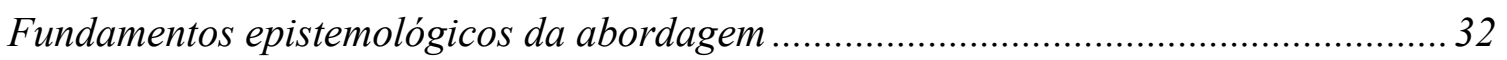

Breve nota técnica sobre as fontes de pesquisa utilizadas........................................... 42

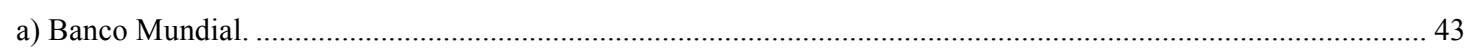

b) O Modelo Latino americano de TDCRs e o Bolsa Família ........................................................................ 44

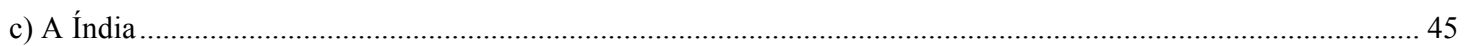

\section{PARTE II - CONTEXTO E PROCESSO HISTÓRICO DO SURGIMENTO E} APERFEIÇOAMENTO DAS TRANSFERÊNCIAS DIRETAS DE RENDA.

CAPÍTULO 2 - AS TRANSFERÊNCIAS DIRETAS DE RENDA....................................................... 47

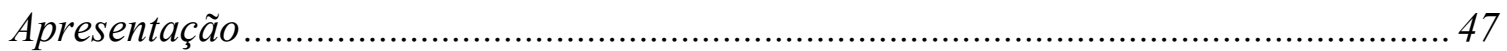

As Garantias de Renda Mínima e a pobreza no Norte ................................................... 50

Pobreza no sul global e as Transferências Diretas de Renda. ...........................................55

CAPítulo 3 - O SURGIMENTO DO MODELO LATINO AMERICANO DE TRANSFERÊNCIAS

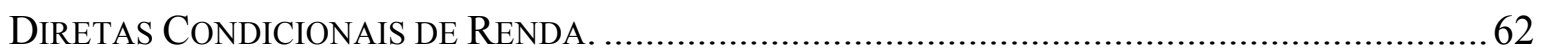

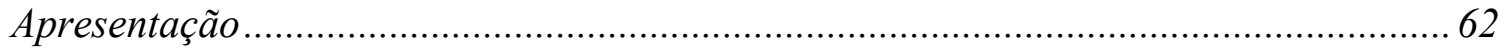

Das primeiras experiências à consolidação do Bolsa Família........................................... 62 
Do Progresa ao Oportunidades: breves notas sobre o caso mexicano. 78

O modelo Latino Americano de Transferências Diretas Condicionais de Renda:

resultados, debates e difusão. 79

Conclusão: 85

CApítulo 4 - Desenvolvimento, Pobreza e o Banco Mundial..................................... 88

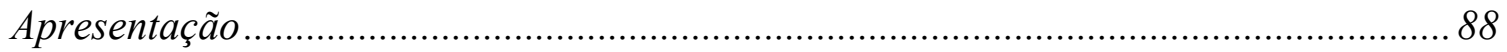

O Banco Mundial Breton Woods: da Reconstrução ao desenvolvimento. ....................... 95

O Banco Mundial e as Politicas de Transferência de Renda ........................................ 118

a) Redes de Segurança como sistema de alívio a situações emergenciais de vulnerabilidade............................ 118

b) A incorporação da ideia de Springboard as Redes de Segurança................................................................... 119

Conclusões: O Banco Mundial e o projeto hegemônico de desenvolvimento. ............... 125

PARTE III - A ÍNDIA E A ÁFRICA DO SUL.

Introdução

Capítulo 5 - As TransferênCias Diretas de Renda Chegam a ÍNDiA ........................ 132

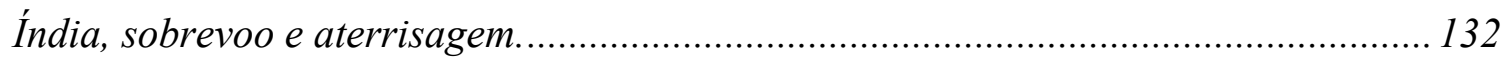

O Estado Nacional Indiano e o desenvolvimento ................................................... 137

As políticas sociais do Governo Nacional Indiano: da segurança alimentar as

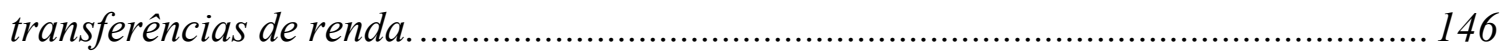

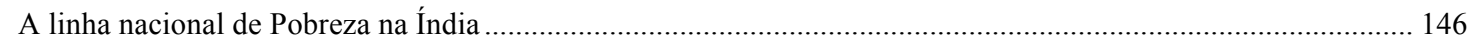

As Transferências Diretas de Renda na Índia, pode-se enxergar uma direção? ................................................... 151

Os programas de transferência de renda na Índia ........................................................ 156

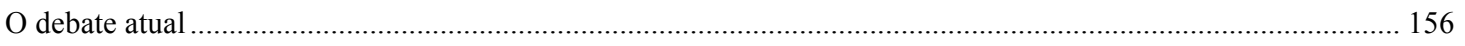

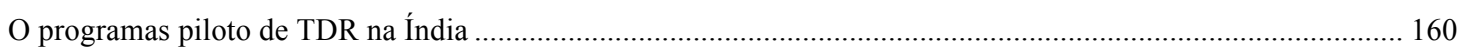

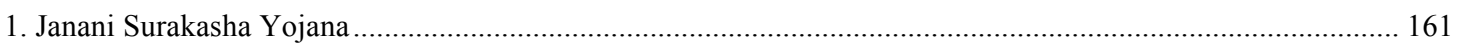

2. Programa de substituição dos subsídios de derivados de petróleo por transferências de renda........................... 163

3. Programa piloto de substituição do PDS por transferências de renda................................................................. 165

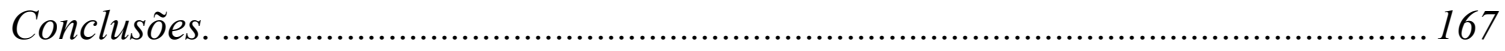

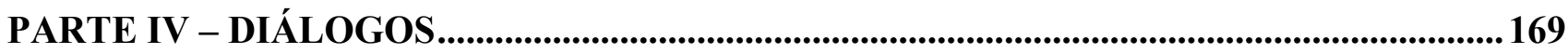

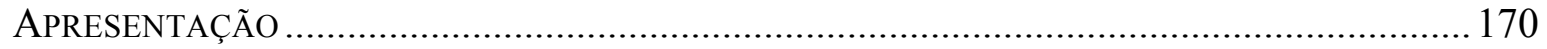

CAPÍtUlo 7 - Modernidade e DesenvolviMento .............................................................. 172

O projeto moderno transborda ao continente europeu................................................ 179

CAPÍTULO 08 - A TEORIA DO DESENVOLVIMENTO E SUA NARRATIVA................................. 189

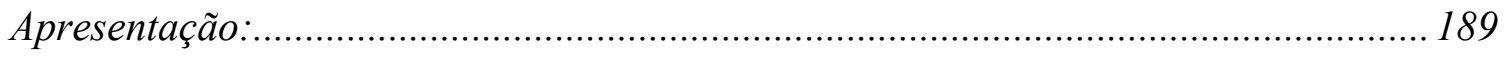


CONCLUSÃO.

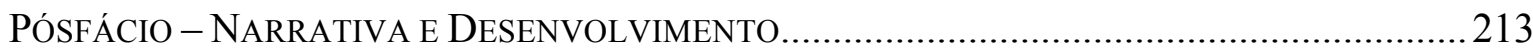

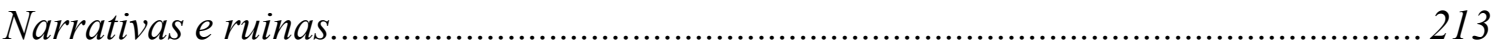

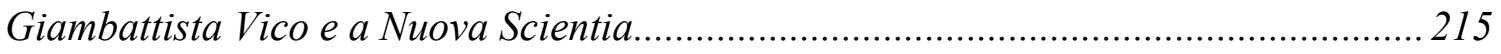

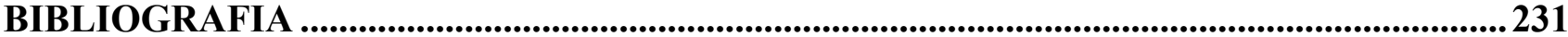




\section{Índice de Figuras}

Figura 1 - Quadro sintético do processo que levou a adoção das redes de segurança como modelo prioritário de proteção social pelo Banco Mundial.

Figura 1 - Ampliação do Escopo dos financiamentos do Banco Mundial - dos anos 1940 até 2000 ...................26

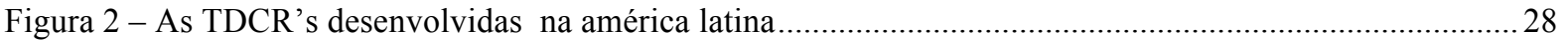

Figura 4 - Expansão das TDCRs apoiadas pelo Banco Mundial........................................................................... 61

Figura 5 - Evolução da taxa de pobreza no Brasil ............................................................................................. 79

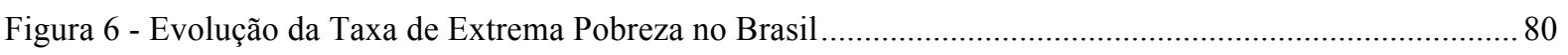

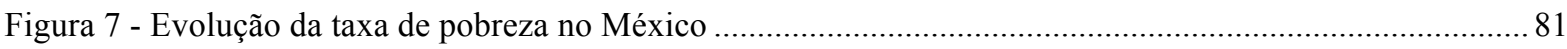

Figura 8 - Mapa do desenvolvimento segundo o Banco Mundial .................................................................... 92

Figura 9 - Emprestimos do Banco Mundial por região em 2013 ..................................................................... 93

Figura 10 - Emprestimos do Banco Mundial por tema em 2013 …………………………............................. 93

Figura 11 - Expansão da agenda do desenvolvimento do Banco Mundial............................................................. 96

Figura 12 - Processo de ampliação da agenda desenvolvimentista do banco mundial ........................................ 110

Figura 13 - Emprestimos do Banco Mundial voltados a políticas de combate a pobreza ..................................... 117

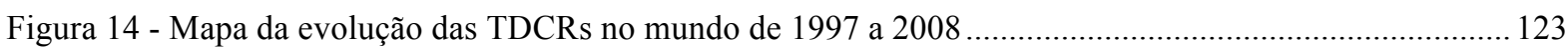




\section{Índice de Tabelas}

Tabela 1 - Tipologia das Transferências Diretas de Renda

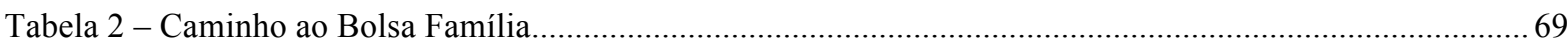

Tabela 3 - Familias beneficiárias e Investimento do Bolsa Família ......................................................... 71

Tabela 4 - Programas de Transferencia Direta de Renda na América Latina ............................................... 85

Tabela 5 - Pobreza e políticas públicas no norte e no sul global............................................................... 86

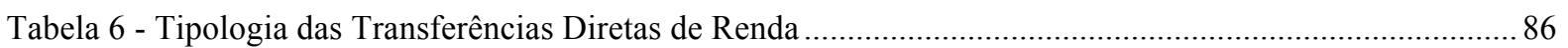

Tabela 7 - Categorias de desenvolvimento segundo o Banco Mundial.......................................................90

Tabela 8 - As etapas do desenvolvimento segundo Rostow .................................................................. 106

Tabela 9 - Histórico de Investimento do Banco Mundial....................................................................... 115

Tabela 10 - Porcentagem da população indiana vivendo baixo da linha da miséria ........................................ 150

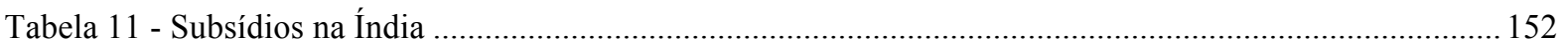




\section{Glossário de Abreviações:}

TDR - Transferências Diretas de Renda.

TDCR - Transferências Diretas Condicionais de Renda.

TDIR - Transferências Diretas Incondicionais de Renda.

GMR - Garantia Mínimas de Renda.

BM - Banco Mundial (neste caso nos referimos apenas a duas das instituições do sistema banco mundial: o Banco Internacional de Reconstrução e Desenvolvimento e a Associação Internacional de Desenvolvimento).

BIRD - Banco Internacional de Reconstrução e Desenvolvimento.

IDA - Associação Internacional de Desenvolvimento.

MDS - Ministério do Desenvolvimento Social e Combate a Fome.

IPC - Comissão Indiana de Planejamento.

PFZ - Programa Fome Zero.

PBF - Programa Bolsa Família.

PT - Partido dos Trabalhadores.

PSDB - Partido da Social Democracia Brasileira.

CCT - Conditional Cash Transfers.

IBAS - Fórum de Diálogo Índia, Brasil e África do Sul.

BRICAS - Brasil, Rússia, Índia, China e África do Sul.

ZHSA - Zero Hunger South África.

OID - Organizações Internacionais de Desenvolvimento. Agrupamos sob esta sigla as instituições ligadas ao projeto hegemônico de desenvolvimento.

AL - América Latina.

EITC - Earned Income Tax Credit

PIB - Produto Interno Bruto

PIBpp - Produto Interno Bruto Percapta 
RNB - Renda Nacional Bruta

RNBpp - Renda Nacional Bruta Percapta 


\title{
Agradecimento e algumas notas pessoais sobre a cartografia desordenada de um doutorado.
}

\begin{abstract}
"Whenever I find myself growing grim about the mouth; whenever it is a damp, drizzly November in my soul; whenever I find myself involuntarily pausing before coffin warehouses, and bringing up the rear of every funeral I meet; and especially whenever my hypos get such an upper hand of me, that it requires a strong moral principle to prevent me from deliberately stepping into the street, and methodically knocking people's hats off-then, I account it high time to get to sea as soon as I can. This is my substitute for pistol and ball. With a philosophical flourish Cato throws himself upon his sword; I quietly take to the ship."
\end{abstract}

Moby Dick, Herman Melville

Dez anos após a conclusão do mestrado, andar novamente pelos corredores tão familiares da UnB parecia estranhamente perigoso. Os outros mares pelo quais velejei antes desta grande odisseia - ensino em instituições privadas, consultorias em ministérios, projetos em organismos internacionais, pesquisas de opinião e posições na gestão de políticas públicas - mal haviam saído de vista e já confirmavam o caráter transitório que sempre desconfiei possuírem em minha vida.

A persistente sensação de estrangeiro que me acompanhava por estas empreitadas, as colocavam um espaço gerúndio que preenchia a espera pela viagem mais esperada de todas. Não foram poucas as vezes que me condenei a não realizar mais a odisseia do 
doutorado e viver de maneira despreocupada pelos caminhos que já se haviam aberto para $\operatorname{mim}$.

No entanto, sendo quem sou, não resisti em ao menos tentar assumir as rédeas e a direção da caminhada. Para me convencer de que a tentativa era real era preciso uma imersão total. E foi isso que fiz, deixei tudo para trás e me lancei ao mar.

As experiências profissionais com as políticas de desenvolvimento social ao longo do governo Lula, possibilitadas por uma vinculação ao partido dos trabalhadores iniciada em 1991, me aproximaram das políticas de desenvolvimento social. As atividades de consultor no programa Bolsa Família do Ministério do Desenvolvimento Social e Combate a Fome e gestor na Secretaria de Juventude da Presidência da República no já extinto PROJOVEM redirecionaram meus interesses acadêmicos. Meu olhar, até então voltado a sociologia da cultura, passam a apontar em direção ao fenômeno do desenvolvimento.

A real dimensão da transição entre governo e a universidade não tardou a assustar. Logo em meu segundo semestre minha perspectiva técnica e utilitarista começou a se desmontar pela pergunta que me foi feita por um dos comentadores do meu projeto inicial: você é um burocrata do governo ou um sociólogo? Os erros e acertos abaixo são o resultada de minha escolha pelo segundo caminho.

Quando ainda investido de um olhar burocrático, herdado das empreitadas anteriores, minha visão ainda se encontrava carregada de um viés elogioso para o Bolsa Família e sustentado sobre os inegáveis resultados positivos sobra a vida de tantos brasileiros. Fatos que eu havia testemunhado de perto. No entanto, a imersão sociológica, não se harmoniza com elogios. Seu olhar é necessariamente impiedoso e exige a exploração dos também de cantos escuros e emaranhados de complexidade.

Também dancei em roda. Isso foi em 1948, os comunistas acabavam de triunfar em meu país, os ministros socialistas e democrata-cristãos tinham se refugiado no estrangeiro, e eu segurava pela mão ou pelos ombros outros estudantes comunistas, nós dávamos dois passos no lugar, um passo para a frente e levantávamos a perna direita de um lado, depois a perna esquerda do outro, e fazíamos isso quase todos os meses, porque tínhamos sempre alguma coisa para celebrar, um aniversário ou um acontecimento qualquer, as velhas injustiças foram reparadas, novas injustiças foram cometidas, as fabricas foram nacionalizadas, milhares de pessoas foram presas, os tratamentos médicos eram gratuitos, os donos de tabacaria tiveram seus negócios confiscados, os velhos operários iam pela primeira vez 
passar as férias nas villas desapropriadas e nós tínhamos no rosto o sorriso da felicidade. Depois, um dia, eu disse alguma coisa que não devia dizer, fui expulso do partido e tive que sair da roda.

Foi então que compreendi o significado mágico do círculo. Quando nos afastamos da fila, ainda podemos voltar a ela. A fila é uma formação aberta. Mas o circulo torna a se fechar e o deixamos sem poder retornar. Não é por acaso que os planetas se movem em círculo e que a pedra que se desprende de um deles afasta-se inexoravelmente, levada pela força centrífuga. Semelhante ao meteorito arrancado de um planeta, saí do círculo e, até hoje, não parei de cair. Há pessoas a quem é dado morrer no turbilhão e há outras que se arrebentam no fim da queda. E esses outros (entre os quais eu estou) guardam sempre consigo uma tímida nostalgia da roda perdida, porque somos todos habitantes de um universo em que todas as coisas giram em círculo.

(Sobre o Riso e o Esquecimento. Milan Kundera)

Se quando figurava nas rodas burocráticas nunca deixei de perceber as sombras que nos rondavam, durante a exploração crítica sociológica procurei não esquecer o que havia visto enquanto de mãos dadas com a gestão daquele projeto social do qual havia participado intensamente.

A escritura de uma tese, apesar de solitária, é uma tarefa que só se realiza com o apoio de muitos. E, portanto, algumas das contribuições que possibilitaram e moldaram esta caminhada não podem deixar de serem mencionadas.

A começar pela influencia sempre positiva aa orientação que recebi do Prof. Marcelo Rosa. A ele devo a aproximação com as leituras decoloniais, a teoria ator-rede e, principalmente, de uma perspectiva sociológica que elevava trabalho de campo ao centro do fazer sociológico que foi capaz de atingir até este irremediável apaixonado pelo prazer intelectual da teoria. A participação no Grupo de Sociologia Não-Exemplar capitaneado por meu orientador foi palco de muitos debates incorporadas nesta tese.

A participação em dois eventos da CLACSO também foram centrais a realização deste trabalho. O curso sobre novas territorialidades conduzidos pelas Professoras Zenaida Garay e Marcela Rosales da Universidade de Córdoba me conectou ao debate sobre espaço e territorialidade que orienta a perspectiva teórica aqui adotada.

Soma-se a esta experiência, minha presença na escola de verão sul-sul realizada Recife em 2012. O contato com estudantes africanos, asiáticos e sul-americanos e as aulas e seminários que assisti, em especial as do prof. Demba Moussa Dembélé do CODESRIA. 
Por este evento acerquei-me do debate sobre a crescente importância das relações sul-sul de forma a tornar inevitável a incorporação desta perspectiva ao trabalho. Deste momento em diante, o Bolsa Família passou a figurar no contexto formado pelas políticas Latino Americanas de Transferência Condicional de Renda, cujo o modelo estava em eminente adoção na Índia e África do Sul. Esta difusão acabou por se configurar em objeto central de análise desta tese.

Por meio de fóruns como o IBAS - Diálogo Índia, Brasil e África do Sul e BRICAS Brasil, Rússia, Índia, China e África do Sul em que experiência como a do Bolsa Família encontrava canais de difusão e despertava uma onda de esperanças contra-hegemônicas aprofundaram ainda mais este interesse.

Comecei a navegar pela difusão do modelo latino americano de transferências de renda e seu modelo de combate a pobreza. De imediato, os ventos me levaram a perceber o papel fundamental do Banco Mundial e o modelo de proteção social baseado em redes de segurança promovidos pela instituição para a compreensão das Transferências Condicionais Diretas de Renda desenvolvidas deste a década de 1990 na América Latina.

Revelou-se nesta parte da investigação aspectos de subalternidade e hegemonização até então ocultos da minha percepção, a visão desconfiada pela qual a critica sociológica lança seu olhar sobre seus objetos começava a se impor. Ao mesmo tempo nesta etapa se tornou evidente o traço Latino Americano sobre as redes de segurança na medida em que eram somadas as ações de mero alívio emergencial a pobreza objetivos mais amplos de quebra dos ciclos geracionais de pobreza.

Segui então para um intenso período de viagens que incluiu 4 meses na África do Sul em contato com a fascinante University of Cape Town e uma temporada de 10 meses em Nova Delhi baseado na não menos fascinante Jawarhalal Nerhu University. Nesta última recebendo a inestimável orientação do Professor Praveen Jha, co-orientador desta tese. Em pouco tempo sua ótica marxista me envolveu e reativou a importância que esta perspectiva tem sobre a minha história intelectual. Não pude mais, desde então, relegar a importância infra estrutural da acumulação capitalista sobre o processo procurava entender e analisar. Ao longo da navegação por estes mares distantes estabeleci contato com pessoas, textos e ideias que certamente seriam de difícil acesso caso tivesse permanecido apenas no Brasil. 
Este período enriqueceu não somente a tese mas - correndo o risco de um exagero sentimental - a minha própria existência.

Os achados por estas andanças não se encaixa completamente em nenhuma das teorias estudadas previamente. De maneira aparentemente contraditória, isso não diminuiu em nada o antigo amor pela teoria. Pelo contrário, reforçou a certeza da sua importância pois fui capaz de melhor posicionar a história do pensamento no fazer sociológico. A teoria não se localizava mais em sua antiga condição totalitária e dominadora a qual de maneira cega procura me subordinar. Agora era parceira de viagem com a qual estabeleci diálogo constante de onde se originaram as principais hipóteses deste trabalho. Assim, sigo incapaz de me cativar pelo vazio histórico e crítico das abordagens meramente descritivas, mas me sinto liberto do absolutismo das teias discursivas nefelibatas, cujo canto tanto já me seduziu.

Emerjo deste período tatuado pelas experiências vividas, ciente da eterna incompletude de um trabalho deste porte, mas renovado pela incrível sensação de completa imersão a uma odisseia pessoal tão temida e desejada. 


\section{Introdução: Do projeto do desenvolvimento as políticas de Transferência de Renda.}

Esta tese descreve o resultado de pesquisa realizada entre os anos de 2012 e 2013 no Brasil, Índia e África do Sul. Trata-se de uma investigação de caráter sociológico que se debruça sobre o fenômeno contemporâneo do desenvolvimento.

O foco de análise é a difusão das Transferências Diretas de Renda (TDR) como estratégia de proteção social e combate à pobreza, processo iniciado em meados da década de $1990 \mathrm{e}$ ainda em curso até os dias atuais. De maneira sintética, este novo formato de política pública voltado ao desenvolvimento social é derivado das crises econômicas causadas pela implementação das medidas de ajuste estrutural por todo o sul global, processo induzido pela ação do Banco Mundial.

$\mathrm{O}$ advento de tais instabilidades financeiras levaram o Banco Mundial a admitir a necessidade de sistemas nacionais de proteção voltados as camadas mais vulneráveis da população ${ }^{1}$. Tal atitude representou um abrandamento da ortodoxia neoliberal hegemônica na instituição por mais de uma década. No entanto, não se tratou de uma guinada radical. O novo modelo de proteção social, apesar das transformações impostas neste período, se manteve fiel aos principais valores elencados no consenso de Washington. Entre os principais indicadores desta relação encontra-se a ação da instituição no desenho e

\footnotetext{
${ }^{1}$ Tal guinada foi anunciada pelo Banco Mundial por meio dos diversos documentos que serão apresentados na parte específica dedicada a este tema
} 
posterior apoio à políticas públicas focalizadas que não desafiam o modelo atual de acumulação capitalista.

No caso específico do combate a pobreza, na conclusão deste processo de transformação vivido pelo Banco Mundial percebe-se o apoio da instituição a implementação de estratégias de desenvolvimento social que não visam a formalização de sistemas de garantias universais mas a constituição de redes de segurança voltadas a parcelas específicas da população. As transferências diretas, condicionais e incondicionais de renda, são o principal modelo de política pública resultante deste movimento.

A escolha deste objeto teve origem no interesse pela intensificação do diálogo e cooperação entre os países em desenvolvimento, característica singular do cenário geopolítico contemporâneo. Dentre os muitos temas que compõem a pauta da cooperação sul-sul, a troca de conhecimento e tecnologias sociais ocupa um espaço de destaque.

No campo específico do combate a pobreza, o programa Bolsa Família do Brasil - PBF figura entre as políticas com maior ressonância nos fóruns internacionais formados pelos países do sul global. O PBF foi apresentado pelo Estado Brasileiro como uma tecnologia nacional de sucesso para o combate a pobreza. Apesar desta retórica, este programa, é apenas um dos muitos formatos de transferências diretas de renda que se espalharam pelo mundo desde a década de 1990. A difusão destas políticas, no entanto, foi desigual pelos diversas regiões do mundo. Foi na América Latina o continente de maior concentração de TDRs e, também, onde se registram os maior e mais bem sucedidos destes programas, o Bolsa Família do Brasil e o Oportunidades do México.

A destaque que estes dois programas assumem no cenário contemporâneo foi impulsionada pela redução da pobreza que pode ser notada desde a implementação desta políticas. O sucesso das transferências diretas de renda, tanto no Brasil como no México, foi ressaltado por políticos e acadêmicos não somente como uma estratégia vitoriosa, mas como um sinal do empoderamento do sul global na esfera mundial do desenvolvimento.

Autores como Joseph Hanlon, Armando Barrientos e David Hulme (Hanlon et Al, 2010) chegam a declarar que se encontrava em curso uma revolução vinda do sul. No entanto, tais análises, como iremos demonstrar adiante, relevam o papel exercido pelas instituições do norte hegemônico neste processo. Assim, procuraremos demonstrar que as TDRs são resultado da mediação entre agentes institucionais do norte e do sul em uma dinâmica 
baseada em relações desiguais e fluxos hegemonizantes e hegemonizados que trafegam tanto de norte a sul, quanto no sentido inverso.

No entanto, no início desta pesquisa tal complexidade ainda não se fazia sentir. Naquele momento a intenção era a de contribuir para a compreensão das características e impactos da promoção e difusão do Bolsa Família pelos canais de cooperação sul-sul. A maior esperança era encontrar possíveis rompimentos ou fissuras no projeto hegemônico do desenvolvimento que, desde sua formalização no período pós-guerra, impôs uma dinâmica vertical de transformações ao sul global.

Em busca de indícios de tal cenário nos voltamos especificamente para a difusão da estratégia de combate a pobreza do Brasil para a Índia e a África do Sul por meio de uma análise do Grupo de Trabalho de Desenvolvimento Social do IBAS, um dos principais fóruns de cooperação sul-sul e, no qual, o Bolsa Família é tema central. O foco principal era identificar as diferenças notáveis entre o diálogo sul-sul e o tradicional norte sul.

O trabalho se iniciou por uma investigação histórica sobre a adoção das transferências de renda na América Latina. O resultado desta etapa, no entanto, produziu impacto de tal dimensão que forçou a pesquisa em nova direção. Isso se deu, pois a leitura dos documentos e artigos sobre o tema expuseram o papel central exercido pelas agencias multilaterais do projeto hegemônico do desenvolvimento, em especial o Banco Mundial, na formulação e difusão do modelo de proteção social baseado em TDRs.

A revolução vinda do sul, em verdade, se mostrou parte de uma transformação mais ampla e complexa ocorrida na matriz global do desenvolvimento e que envolve tanto atores do sul quanto do norte global. Portanto, para compreender o fenômeno da difusão das transferências diretas de renda como forma de combate a pobreza, foi preciso entender o papel de actantes de ambos os espaços de experiência do sistema mundo contemporâneo.

\section{O norte global e as Transferências Diretas de Renda}

Como já indicamos brevemente acima, a origem do novo modelo de proteção social do qual as Transferências diretas de Renda fazem parte e que hoje se difunde pelo mundo pode ser traçada ao contexto de implementação dos chamados ajustes estruturais. O 
condicionamento de empréstimos do Banco Mundial a "adequações" na organização econômica dos países do sul global iniciada ao final dos anos 1970 conduziu a uma piora nos indicadores sociais dos países receptores de fundos da instituição. Foram estes impactos negativos, admitido pelo próprio Banco Mundial no ano de XXXX, que marcaram o enfraquecimento da hegemonia neoliberal na instituição e, ao mesmo tempo, abriram-se as portas para que o desenvolvimento social se elevasse ao centro das preocupações do BIRD..

A reposta das agências multilaterais de desenvolvimento a este cenário de deterioração dos quadros sociais dos países "em ajuste" se deu por meio do apoio a constituição e implementação de sistemas nacionais de proteção social para as populações economicamente mais vulneráveis. Tais sistemas deveriam ser constituídos de programas focalizados e emergenciais com o objetivo de formar uma rede de segurança nacional para as famílias de baixa renda acessível com o intuito de prover de alívio as mesmas em momentos de instabilidade econômica. Defenderemos ao longo desta tese que estímulo a implementação de modelos de proteção proteção social baseados em rede de segurança é marcado por duas características de destaque: a centralidade do tema pobreza e a adoção das TDRs.

De uma perspectiva mais ampla a centralidade que o combate à pobreza assume hoje no Banco Mundial configura-se como o ultimo capítulo do processo de ampliação da agenda do que chamamos aqui de projeto hegemônico do desenvolvimento ${ }^{2}$ no qual o BIRD tem papel de destaque.

A identificação do Banco Mundial com tal projeto não pretende desprezar as complexidades internas da instituição e nem categorizá-la como uma estrutura coerente e sem conflitos. No entanto, seguindo os preceitos da teoria ator-rede compreendemos este actante pelas sua agencia e efeitos sobre sua rede de relações. Assim,

Breton Woods foi o berço deste projeto que atualmente completa 6 décadas ao longo dos quais o termo desenvolvimento foi redefinido e ampliado múltiplas vezes. Durante este processo este conceito passou a abranger desde obras de infraestrutura até modelos de política social.

\footnotetext{
2 Trata-se da ação articulada de instituições dominadas pelo norte global para impor um conjunto de transformações as sociedades do sul. Ao longo da tese este termo será definido de forma mais detalhada.
} 
No momento inicial de constituição das agências internacionais de desenvolvimento, o termo designava apenas a promoção de crescimento do Produto Interno Bruto das excolônias europeias por meio do financiamento de infraestrutura exportadora nestes territórios (Kapur et Al, 1997). As primeiras ampliações da agenda desenvolvimentista de instituições como o Banco Mundial podem ser notadas ao longo dos anos 60 e 70, período no qual as estas passaram a incluir em suas diretrizes a promoção da industrialização dos países do sul global. No momento desta ampliação a teoria da modernização era a linha de pensamento hegemônica na instituição. Autores alinhados com esta perspectiva, como W. W. Rostow, defendiam uma visão linear e universal de progresso na qual a industrialização aparecia como etapa necessária ao desenvolvimento das nações.

$\mathrm{Na}$ segunda metade dos anos 70, a agenda hegemônica do desenvolvimento sofre nova expansão. Além da infraestrutura e industrialização as agências internacionais ampliam seus interesses em direção a modelos de gestão moderna, combate à corrupção e a liberalização da economias das ex-colônias.

O presidente do Banco Mundial deste período, Robert Macnamara, foi também o primeiro a incluir o combate a pobreza na agenda da instituição. (Kapur et Al, 1997) No entanto, esta incorporação ficou limitada ao discurso e produziu poucos efeitos práticos nas diretrizes de empréstimos do BIRD.

A ampliação da agenda hegemônica do desenvolvimento viveu novo capitulo com a chegada dos anos 1980 e a emergência dos valores neoliberais às agências internacionais como nova matriz ideológica em substituição os preceitos da teoria da modernização. Estado mínimo, combate a inflação, diminuição dos gastos sociais passam a compor o conjunto de demandas feitas em nome do desenvolvimento aos países do sul global.

Foi também durante as décadas de 1970 e 1980 que a efetividade das pressões exercidas pelas agências multilaterais sobre os países do sul global ganhou grande impulso. Isso ocorreu devido ao aumento da dependência em relação aos empréstimos oferecidos pelos organismos internacionais, condição precipitada pelas crises econômicas do período.

Aproveitando-se deste cenário de "default" nas contas públicas dos países em desenvolvimento o Banco Mundial - BM passou a exigir das nações clientes contrapartidas a concessão de empréstimos que implementassem uma versão radicalizada 
de capitalismo como caminho para a superação das crises de balanço de pagamentos que se espalhava pelo sul global.

As medidas que compunham o novo ideário do Banco Mundial foram chamadas Consenso de Washington ${ }^{3}$, e demandavam aos países da periferia: a liberalização das economias, a redução do estado, controle da inflação e a responsabilidade fiscal.

A fragilidade dos países do sul global e a consequente dependência de empréstimos internacionais propiciou uma intensa disseminação dos ajustes estruturais ${ }^{4}$. No entanto, como já afirmamos acima, a implementação destas políticas provocou diversas crises econômicas o que levou a piora dos indicadores sociais dos países que as adotaram ${ }^{5}$. Em resposta a este quadro negativo as agencias internacionais foram forçadas a ampliar novamente sua agenda desenvolvimentista. As questões sociais foram então retiradas do plano da retórica e um volume significativo de recursos do portfólio de investimentos do Banco Mundial foram direcionados a promoção de políticas sociais.

Trata-se do que Jonathan Murphy chama de "Poverty Turn" (Murphy, 2008), momento em que o Banco Mundial se volta definitivamente aos temas sociais e, em especial, ao combate à pobreza. Discurso que a instituição sustenta até o momento presente.

Esta virada foi oficializada no ano de $1993^{6}$ quando o Banco Mundial publicou documento reconhecendo a necessidade de implementação de sistemas nacionais de proteção social voltadas à populações economicamente vulneráveis atingidas pelas crises advindas dos ajustes estruturais.

\footnotetext{
3 Termo cunhado por John Williamson (Williamson, 2004)

${ }^{4}$ Segundo Patnaik, (2006) ao menos 78 países clientes dos Banco Mundial adotaram total ou parcialmente as medidas de ajuste.

${ }^{5}$ Sendo as principais a da Rússia, argentina, México e Brasil.

${ }^{6}$ Documento Social Security Reforms and Social Safety Nets
} 
Figura 1 - Quadro sintético do processo que levou a adoção das redes de segurança como modelo prioritário de proteção social pelo Banco Mundial.

- A crise do petroleo dos anos 1970 e o fim do sistema Bretton Woods estão entre as causas do alto endividamento das economias periféricas

- 0 resultado deste cenário é a crescente dependência dos países do sul global de empréstimos das agências multilaterais

- Diante da alta dependência de empréstimos externos por parte dos países do sul global o Banco Mundial impõem condições aos empréstimos feitos aos países clientes

- Estas condicionalidades - chamadas ajustes estrturais ou medidas do consenso de Washington promovem o ideário neoliberal.

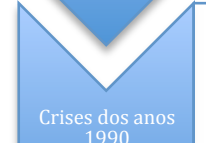

- A adoção das medidas do consenso de washington leva a transformação das economias periféricas gerando um conjunto de crises economicas ao longo dos anos 1990

- Os principais exemplos destas instabilidades ocorreram México em 1994/95, o Brasil em 1997/98, a Argentina em 1999/01 e a Rússia em 1997/98

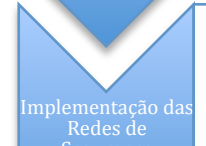

-Diagnósticos demonstram que as populações pobres são as mais atingidas pelas crises causadas pela implementação dos ajustes estrturais.

•Em 1991 o Banco Mundial inicia a promoção das redes de segurança como formato de proteção social as populações economicamente vulneráveis

O Banco passou, desde então, a promover a criação de "safetynets", ou redes de segurança, constituídas por políticas voltadas ao alívio emergencial de situações de vulnerabilidade. As transferências diretas de renda se encaixam neste modelo. No entanto, apesar da continua aproximação do Banco Mundial com a temática da pobreza as transferências diretas de renda foram inicialmente direcionadas a diversos temas sociais, tais como trabalho infantil, segurança alimentar, frequência escolar, entre outros.

O quadro abaixo sintetiza a expansão dos temas tratados e financiados pelo Banco Mundial ao longo de sua história de acordo com Kapur (Kapur et Al, 1997): 


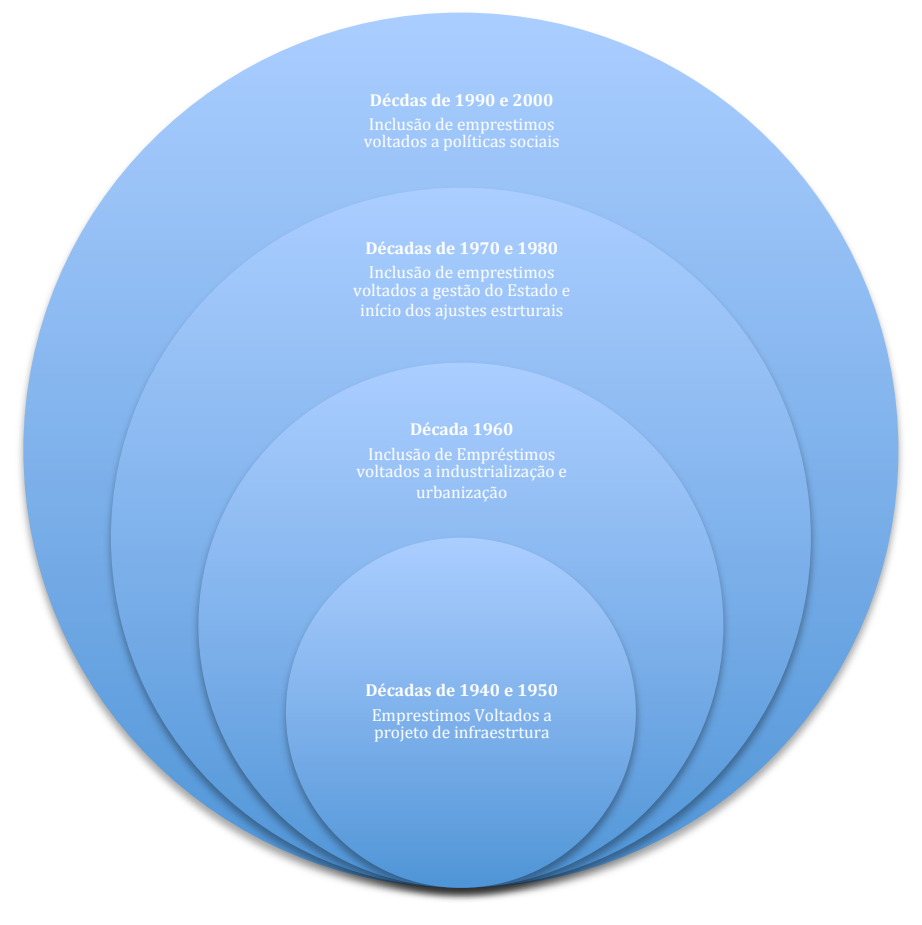

b) A participação do sul global no desenvolvimento das Transferências Diretas de Renda.

A implementação de Transferências Diretas de Renda pelo Sul Global foi marcada por imensa diversidade de formatos. No entanto, dois tipos gerais podem ser identificados: a) as Transferências Incondicionais e b) as Condicionais de Renda.

As Transferências Incondicionais de Renda são políticas não contributivas que representam a materialização estrita do modelo proposto pelo banco mundial. São programas focalizados, cujo objetivo é prover alívio emergencial a populações em condição de vulnerabilidade durante períodos de crise.

Este modelo foi o primeiro a ser promovido pelo Banco Mundial diante dos problemas gerados pelos ajustes estruturais. Se tratam normalmente de políticas transitórias e pontuais. A adoção destas estratégias pelas agências multilaterais de desenvolvimento está em sintonia com os preceitos neoliberais.

Já as Transferências Condicionais de Renda não se configuram como somente uma mera aplicação do ideário prescrito desde o Banco Mundial. Isso, pois além do provimento de 
alivio emergencial a populações em condição de vulnerabilidade, mas procuram gerar mudanças de hábitos entre os beneficiários.

De forma sintética, estes programas exigem contrapartidas aos indivíduos ou famílias que recebem o benefício governamental que procuram induzir coisas, como: aumentar a frequência escolar, impedir o trabalho infantil, aumentar a incidência de partos em instituições formais de saúde ou, até, de desestimular casamentos precoces.

Tal extrapolação da proposta original das redes de segurança sistematizada pelo Banco Mundial representa por um lado que os agentes do sul envolvidos na matriz do desenvolvimento detém poderes, embora limitados, de mediação apesar das relações assimétricas estabelecidas com os actantes do norte.

Por outro lado, ao olhos dos críticos destas políticas, estas representam um aprofundamento ainda maior da tentativa de modelagem societal e comportamental dos povos do sul característico do projeto do desenvolvimento desde o seu início.

Entre os programas de TDCR desenvolvidos no mundo desde a década de 1990, foi na América Latina que um modelo voltado especificamente ao combate a pobreza se constituiu. E, como já citamos anteriormente, os dois programas mais representativos deste modelo são o Oportunidades do México e o Bolsa Família do Brasil.

A principal particularidade destas políticas públicas é a de agregar condicionalidades visando gerar quebras dos ciclos geracionais de pobreza nas famílias de baixa renda. A figura abaixo procura localizar os programas latino americanos no modelo de proteção social baseado em rede de segurança proposto pelo Banco Mundial deste a década de 1990. 


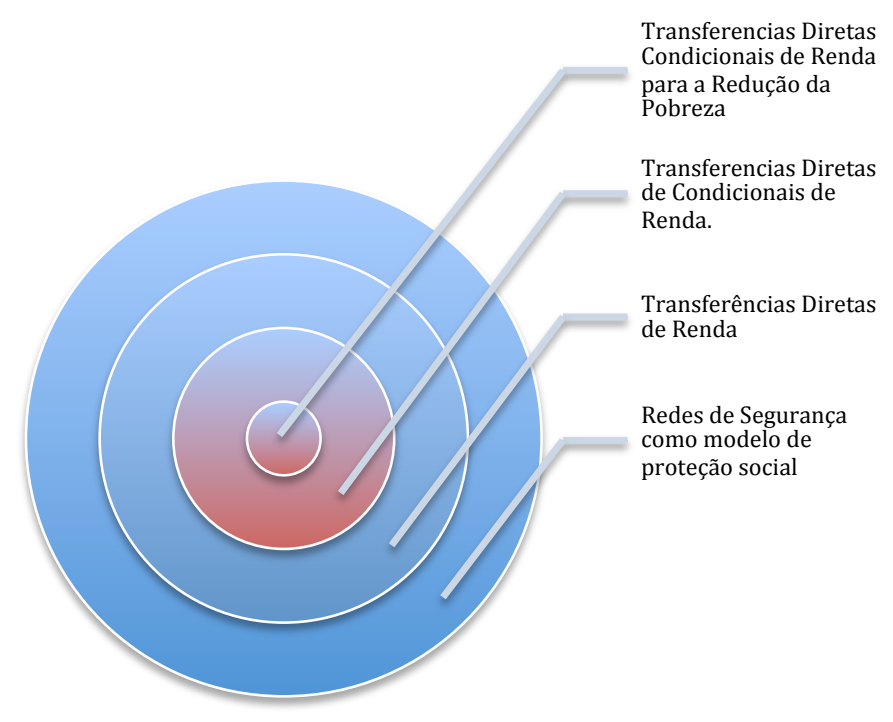

Os resultados positivos alcançados por estes dois programas na redução dos índices de pobreza nos dois países levaram o Banco Mundial a incluir paulatinamente este modelo em sua própria agenda de financiamentos, processo que se iniciou no ano de 2003.

Assim, podemos afirmar que se desenvolveu um modelo Latino Americano de TDCR. Sua constituição, no entanto, não é endógena a região, mas fruto da interação, mesmo que assimétrica, entre agentes do sul e do norte global. Os países em desenvolvimento demonstram neste caso sua capacidade de agencia na matriz global do desenvolvimento, ou seja, são capazes de gerar efeitos significativos sobre o cenário até então hegemonizado pelo norte.

Atualmente tanto as instituições vinculadas aos norte global quanto os estados em desenvolvimento, por meio dos fóruns de cooperação sul-sul, promovem a estratégia de combate à pobreza desenvolvida na América Latina.

Pela ação de todos estes agentes, variações do modelo latino americano de TDCR passaram a ser desenvolvidos ou adaptados em diversos países do sul global. Em 2010, ano em que esta pesquisa se iniciou tanto Índia quanto África do Sul aparentavam casos promissores de estudo de como a difusão das TDCRs para o combate à pobreza estava a ocorrer.

Diante deste quadro, esta tese se propôs a cumprir três objetivos principais de pesquisa. 
a) Apresentar o cenário histórico de surgimento da estratégia latino-americana de combate à pobreza por meio da descrição da agência de alguns dos principais agentes envolvidos neste processo.

b) Apresentar as particularidades das TDCRs, quando relacionadas ao quadro amplo de políticas públicas que se enquadram no modelo de proteção social baseado em redes de segurança.

c) Descrever aspectos do processo recém iniciado de implementação de modelo similares as TDCRs latino americanas na Índia e África do Sul.

\section{Estrutura da Tese}

Para além desta introdução e da apresentação que a precedeu está tese é composta por três partes, uma conclusão e um pósfácio.

$\mathrm{Na}$ parte I, denominada Abordagem ao Objeto e formada pelos capítulos 1 e 2, discutiremos os princípios metodológicos utilizados nesta tese e apresentaremos algumas notas de como foi realizado o trabalho de campo. Em termos epistemológicos, esta tese procura se afastar da centralidade que a categoria tempo exerce na narrativa hegemônica. As agências multilaterais de desenvolvimento são instituições dominadas pelas nações doadoras do norte global e procuram conduzir transformações nas sociedades do sul global de acordo com os próprios padrões societais. Nesta primeira etapa da tese procura-se explicitar os fundamentos metodológicos que sustentam o percurso adotado.

A Parte II é composta de quatro capítulos, cujo primeiro será dedicado vincular as TDCRs a uma perspectiva de pobreza atribuída especificamente ao sul global e fornecer uma descrição tipológica destas politicas. O segundo tem como objetivo descrever o modelo latino-americano de TDCR para o combate à pobreza com ênfase no caso do Bolsa Família brasileiro e a disseminação desta políticas pela região. $O$ terceiro tem como foco a participação do Banco Mundial neste processo e a difusão que tais políticas para além do continente sul americano. Por fim apresentamos os resultados da pesquisa de campo realizada na Índia

A seguir, na terceira parte composta por dois capítulos nos empreendemos uma discussão de cunho histórico conceitual. O primeiro deles procura explorar as conexões entre a 
experiência moderna europeia e o discurso dos agentes do projeto hegemônico do desenvolvimento. O capítulo posterior, tem como principal objetivos realizar um sobrevoo crítico sobre a chamada teoria do desenvolvimento.

A parte III encerra o desenvolvimento da tese e abre caminho para o texto de conclusão onde procura-se agrupar de forma sintética os pontos mais relevantes da mesma.

É de imensa importância para a construção dos argumentos expressos nesta tese uma percepção do desenvolvimento como uma narrativa foi incluído um pósfácio em que tal característica é explorada de forma mais detalhada. 
Parte I - Abordagem ao objeto: opções metodológicas, pesquisa de campo e fontes. 


\section{Capítulo 1 - Escolhas metodológicas e notas sobre o trabalho de campo}

\section{Fundamentos epistemológicos da abordagem}

A abordagem metodológica desta tese foi construída a partir de um diálogo improvável entre três perspectivas que, a princípio, parecem de difícil enlace. Incorporamos aspectos tanto da teoria ator-rede, o modelo de representação centro/periferia e elementos do pensamento decolonial latino americano.

Da teoria ator-rede, adotamos a crítica ao método científico tradicional das ciências sociais. Segundo os autores vinculados a este pensamento, os procedimentos clássicos das ciências sociais resultam em representações estabilizadas do social que, em verdade, é fluído e instável.

As ciências sociais ao estabilizar o social procuram capturar e estabilizar o social. No entanto, ao submeter os objetos de pesquisa ao desejo ordenador da metodologia tradicional perde-se a incerteza e o movimento que também caracteriza o social.

Uma das principais marcas deste procedimento epistêmico dominante são a enunciação de leis e formulas atemporais que silenciam a fluidez, as particularidades e diferenças entre actantes, espaços, relações e histórias. John Law (2004) afirma:

(...) overall, the social is taken to be fairly definite. Such is the framing assumption: that there are definite processes out there that are waiting to be discovered. (Law, 2004:6) 
Nos somamos aqui ao pensamento de Law e procuramos fundamentar a estratégia epistemológica sobre uma percepção de social não pacificado e inconstante. O desafio proposto ao cientista social pela teoria ator-rede é o de reconstruir constantemente o social e com isso dar relevância as relações instáveis e singulares entre actantes sociais em transformação e assim gerar representações que não silenciam o lado fluido e elusivo do social.

Outro dos efeitos negativos da estabilização do social é risco de submete exageradamente o trabalho de campo a um sistema de pressupostos ideológicos. Muitas vezes o resultado é o processo de seleção e distorção do fenômeno investigado para que este se enquadre nos pressupostos teóricos do pesquisador. Procura-se, como exige o método científico tradicional buscar indícios de uma hipótese erguida sobre paradigmas das teorias gerais do campo de estudo.

Procuramos aqui, pelo contrário, atribuir centralidade a descrição dos achados ao longo da pesquisa, a partir dos quais conduziremos um diálogo crítico com a literatura acadêmica.

Entretanto, não assumimos esta perspectiva de maneira acrítica. A visão de Law e Latour está também carregada de utopias. A principal delas é a crença na descrição como caminho para uma análise social desprovida de pressupostos. Claro, não ha pesquisa ou descrição neutra ou alheia a discursos e correntes teóricas.

Se a busca de leis gerais estáveis pode constituir uma armadilha metodológica, por outro lado, voltar-se exclusivamente a descrição leva a investigação social a uma cilada de igual dimensão. O caráter político, cultural e ideológico está presente na pesquisa desde seu princípio. O olhar do pesquisador já se encontra condicionado por aspectos linguísticos e discursivos, as vinculações institucionais e os recortes estabelecidos para a viabilização da investigação, entre outros.

Apesar desta crítica, acreditamos que a opção pelo esforço de reconstrução do social a cada investigação por si só apresenta três vantagens em relação a metodologia tradicional das ciências sociais: a) atribui mais relevância ao trabalho de campo e, portanto, mais espaço a achados inesperados e b) permite uma melhor percepção do caráter fluido e efêmero do social e c) da mais abertura a percepção de aspectos inesperados do fenômeno investigado. 
A prática da estabilização do social não está restrita ao campo acadêmico. As instituições do projeto hegemônico do desenvolvimento também incorrem no mesmo método ao atribuírem caráter linear e universal a narrativa histórica do progresso. Como afirma Heeks (2013):

\begin{abstract}
ANT offers a new perspective on all aspects of development: its concepts, structures and processes. It is a view that disputes linear and objectivist visions of development and which moves beyond the dualities of technology vs. society, macro vs. micro; instead offering a more complex and emergent view that, arguably, adheres more closely to the lived experiences of development projects and processes. (Heeks, 2013:2)
\end{abstract}

Outro aspecto da teoria ator rede foi incorporado a abordagem metodológica adotada. Bruno Latour, em sintonia com o pensamento de Law, define o objetivo das ciências do social como a identificação das associações entre os agentes envolvidos. As relações entre os actantes são constantemente impactadas e transformadas pela agência dos mesmos e causam alterações na complexa teia formada pelos agentes em rede.

Even though most social scientists would prefer to call 'social' a homogeneous thing, it's perfectly acceptable to designate by the same word a trail of associations between heterogeneous elements. Since in both cases the word retains the same origin-from the Latin root socius - it is possible to remain faithful to the original intuitions of the social sciences by redefining sociology not as the 'science of the social', but as the tracing of associations. (Latour, 2005:5)

Assim, além de incorporar o caráter fluido e efêmero do social a teoria ator-rede centralidade as relações entre agentes sociais e as redes formadas e reformadas por estes.

De acordo com Law, o actante não pode ser percebido como uma entidade pura ou isolada. Sua constituição se dá por meio das relações que este estabelece e, portanto, o agente social e suas relações são indissociáveis.

Actors are entities, human or otherwise, that happen to act. They are not given, but they emerge in relations. (Law, 2004:102)

O estudo isolado dos elementos de uma rede, não permite que aspectos importantes do social sejam percebidos. Nesta tese, os efeitos da agencia dos actantes no emaranhado social se constituem como os principais indicadores para a caracterização do mesmos. Desta forma, a complexidade interna dos agentes institucionais do desenvolvimento, 
embora importante para compreensão das origens de suas atuação, não faz parte do recorte que impusemos ao sujeitos aqui abordados. Nos limitamos aqui aos efeitos da agência concreta final dos actantes aqui pesquisados, resultante, entre outras coisas, da complexidade interna de instituições como o Banco Mundial. Tais efeitos só podem ser notados e descritos por meio das consequências geradas nos demais actantes participantes da matriz do desenvolvimento. O caráter generativo das relações implica que estas tem papel central na constituição de realidades particulares, o que está em sintonia com o pensamento de Law, como podemos perceber no trecho:

But together they are a way of pointing to and articulating a sense of the world as an unformed but generative flux of forces and relations that work to produce particular realities. (Law, 2004:6/7)

Estes princípios epistemológicos fundamentam o que Law denomina método assemblage. (Law, 2004) Em última análise, trata-se de direcionar a pesquisa social a identificação e representação de agentes sociais e suas relações como caminho pelo qual podemos melhor nos aproximar de um social instável.

Law afirma que as assemblages são compostas de três tipos de relação: a) as de caráter explícito, b) as que se encontram manifestas, mas não explicitas e c) as que estão escondidas ou reprimidas.

More specifically, it is the crafting, bundling, or gathering of relations in three parts: (a) whatever is in-here or present (for instance a representation or an object); (b) whatever is absent but also manifest (it can be seen, is described, is manifestly relevant to presence); and (c) whatever is absent but is Other because, while necessary to presence, it is also hidden, repressed or uninteresting. (LAW, 2004:84)

De forma sintética, a adoção destes aspectos da teoria-ator rede tem como objetivo perceber o espaço de experiência (Kosseleck, 2004) ${ }^{7}$ do desenvolvimento como instável, móvel e fluido o que significa, em termos práticos, identificar os agentes e relações que constituem a assemblage do desenvolvimento.

Consideramos que a TAR nos direciona para a construção de uma representação espacializada do desenvolvimento. Isso pois, em última análise uma assemblage é um

\footnotetext{
${ }^{7}$ Utilizamos aqui o termo cunhado por Reinhart Kosseleck em seu livro futures past (2004) em que o autor procura definir teritorialidade como um espaço demarcado pela experiência que acumula dispõem o tempo de forma não cronológica.
} 
mapa topográfico da matriz formada por actantes interconectados que constituem uma realidade particular.

O principal interesse desta pesquisa está focado no processo de difusão das TDRs. Para dar conta deste aspecto incorporamos ao trabalho a geografia crítica de Milton Santos.

\begin{abstract}
"considerado como uma todo o espaço é um teatro de fluxos com diferentes níveis, intensidades e orientações. Ha fluxos hegemônicos e hegemonizados, fluxos mais rápidos e eficazes e fluxos mais lentos. O espaço global é formado de todos os objetos e fluxos." (SANTOS, 2008:49)
\end{abstract}

Santos afirma que o espaço global é composto tanto por objetos quanto por fluxos. Se a TAR defende que as ciências sociais tem como principal objetivo identificar uma rede de agentes em relação e a assemblage que estes constituem, o geógrafo brasileiro nos permite incorporar um novo elemento central a caracterização do social.

Fluxos são movimentos difusórios que impactam paulatinamente diversos actantes em assemblage. E é justamente a configuração originada das relação estabelecidas entre os agentes em rede que irá caracterizar o tipo de disseminação que ira ocorrer.

Esta incorporação nos permite lidar com uma das mais recorrentes criticas direcionadas a TAR. Trata-se do que Heeks (2013) denomina acusação moral e onde se denuncia o silencio ou a importância secundária dada por Latour e Law a desigualdade de poder entre os agentes em rede, como podemos notar na citação abaixo:

\begin{abstract}
Morally, the accusation has been that ANT is amoral and apolitical: silent on the unequal distributions of power that enable some translations and then networks to dominate over others. (Heeks, 2013:9)
\end{abstract}

Embora tanto John Law quanto Bruno Latour disputem esta análise, nos filiamos a esta critica feita a TAR. Esta lacuna nos parece reflexo de um desejo extremo de dissociação metodológica em relação ao fazer sociológico tradicional, submisso as grandes narrativas ideológicas. Como veremos no último capítulo da parte IV a própria narrativa histórica como formato de enunciação do mundo evidencia fundamentos ideológicos da epistemologia das ciências sociais e do conhecimento ocidental.

No entanto, a nosso ver, não ha incompatibilidade intrínseca entre TAR e inclusão da caracterização política das conexões establecidas entre os agentes em assemblage. É justamente a identificação deste caráter desigual que permite tipificarmos os fluxos que 
ocorrem no espaço global. Por exemplo, quando fluxo dissemina a partir de agentes dominantes em direção ao subalternos constitui-se um fluxo hegemonizante.

Para representar as relação de dominância e subalternidade incorporamos o modelo centro centro/periferia. Apresentar o desenvolvimento por meio de um mapa concêntrico destaca o tipo de relação estabelecida entre os agentes do desenvolvimento em assemblage e que condicionam os fluxos que se difundem entre eles.

A adoção deste modelo não significa que exista uma cisão ou quebra nas relações estabelecidas entre espaços periféricos e centrais. Pelo contrário, como afirma Borgatti e Everett (1999), trata-se de um todo inquebrantável formado de actantes acoplados, interdependentes e desiguais.

One intuitive view of the core/periphery structure is the idea of a group or network that cannot be subdivided into exclusive cohesive subgroups or factions, although some actors may be much better connected than others. The network, to put it another way, consists of just one group to which all actors belong to a greater or lesser extent. (Borgatti e Everett, 1999:376)

O modelo centro/periferia foi aplicado pela primeira vez ao desenvolvimento por Raul Prebish, sendo posteriormente incorporada tanto pela teoria da dependência quanto do sistema-mundo. Ambas as correntes procuravam erguer suas leituras sobre desenvolvimento a partir de um mapa concêntrico que, em última análise, é composto por agentes nacionais em relação desigual.

a social system, one that has boundaries, structures, member groups, rules of legitimation, and coherence. Its life is made up of the conflicting forces which hold it together by tension and tear it apart as each group seeks eternally to remold it to its advantage. It has the characteristics of an organism, in that it has a life-span over which its characteristics change in some respects and remain stable in others. One can define its structures as being at different times strong or weak in terms of the internal logic of its functioning. (Wallerstein, 2011:347)

A citação acima em que Wallerstein define sucintamente sua ideia de sistema mundo, atribui importância a fatores pouco destacados na TAR, tais como: tensões, estabilidades e forças. No entanto, ambas as correntes e a geografia crítica de Milton Santos comungam na atribuição de centralidade as relações estabelecidas entre agentes que são representadas em um mapa topográfico. 
Tanto a teoria ator rede como a representação centro/periferia atribui protagonismo na leitura do social ao recurso epistêmico da espacialização. Isso significa que o social, embora resultante de um processo histórico, será representado como um espaço em que experiência humana se realiza e, como afirma Kosselleck (2004), o passado, o presente e o futuro estão presentes de maneira não sequencial.

A importância das relações entre agentes nestas teorias pode ser notada pela ideia defendida por eles de que o próprio progresso e avanço tecnológico das nações desenvolvidas e não-desenvolvidas são resultantes das conexões estabelecidas entre estes actantes. Assim como afirmou Law, são as relações estabelecidas entre os agentes que caracteriza, tanto os agentes, como o próprio sistema-mundo.

A teoria do Desenvolvimento e do Sistema-Mundo são correntes que floresceram em período que o desenvolvimento se resumia basicamente a busca pelo crescimento econômico e industrialização nos países periféricos. Este aspecto somado a influencia marxista vinculou profundamente estes termos a relações econômicas e, por consequência, relegou os aspectos simbólicos e ideológicos a um segundo plano.

O decolonialismo latino americano em especial, nas obras de Walter Mignolo, Enrique Dussel e Anibal Quijano tem militado para trazer a relação de subordinação epistêmica dos espaços coloniais para uma posição central na análise da configuração do mundo contemporâneo.

Anibal Quijano, pela oposição entre colonialidade e modernidade, expõe o processo violento de imposição de valores modernos eurocêntricos por meio das relações entre metrópole e colônia, como podemos notar no trecho abaixo sobre a construção da américa latina:

Con la constitución de América (Latina), en el mismo momento y en el mismo movimiento históricos, el emergente poder capitalista se hace mundial, sus centros hegemónicos se localizan en las zonas situadas sobre el Atlántico-que después se identificarán como Europa-y como ejes centrales de su nuevo patrón de dominación se establecen también la colonialidad y la modernidad. En breve, con América (Latina) el capitalismo se hace mundial, eurocentrado y la colonialidad y la modernidad se instalan asociadas como los ejes constitutivos de su específico patrón de poder, hasta hoy. (Quijano, 2007: 93/94) 
Procuramos incorporar este aspecto do pensamento decolonial com o intuito de inclir a dominação epistêmica entre as relações desiguais que o modelo centro e periferia procura representar. Com isso, nos distanciarmos da centralidade que a dimensão econômica imbuída nas ideias de centro e periferia optaremos aqui pela termos sul e norte global. Como afirma Rosa (2014), não se trata de uma localização geográfica e sim um posicionamento geopolítico, histórico e epistemológico cujo uso procura expressar as múltiplas dimensões da dominação e subordinação que caracterizam as relações entre os actantes da assemblage do desenvolvimento.

A adoção de tais termos está em sintonia com a proposta de subversão epistêmica apresentada por Ana Estar Ceceña, que afirma:

De cualquier manera, la construcción de nuevos conceptos y nuevos modos de mirar la vida es ineludible para permitirles salir de viejos encierros. No hay subversión posible si no abarca el pensamiento, si no inventa nuevos nombres y nuevas metodologías, si no transforma el sentido cósmico y el sentido común que, como es evidente, se construyen en la interacción colectiva, haciendo y rehaciendo socialidad. (Cecena, 2006:14)

Assim, de forma sintética aproveitamos aqui a) a proposição da teoria ator-rede de um social móvel, instável e efêmero que direciona a pesquisa para a caracterização dos actantes, suas relações e efeitos no campo do desenvolvimento e b) a partir da imagem de norte e sul global dar protagonismo ao longo da análise as relações desiguais de dominação entre os agentes envolvidos.

Sobre estas escolhas epistemológicas se erguem os esforços para a compreensão da difusão do combate a pobreza por meio de transferências diretas de renda que realizamos nesta tese e nos conduziu a três objetivos:

a) $\mathrm{O}$ mapeamento dos $\operatorname{actantes}^{8}$ centrais ao processo de criação e difusão do modelo de proteção social por meio de redes de segurança.

b) A procura por evidencias da difusão destas políticas e seu impactos nos sistemas estabelecidos de proteção social na Brasil, Índia e África do Sul

c) A identificação e caracterização dos fluxos que compuseram este processo.

\footnotetext{
${ }^{8}$ Utilizamos aqui a ideia de actante pensado de acordo com a obra de latour. Na qual a ideia de agencia só se confirma quando esta causa efeitos na assemblage ator-rede (Latour, 2006)
} 
O Banco Mundial é um dos actantes centrais a difusão das TDRs como política de proteção social contra a pobreza. Trata-se de um dos agentes mais importantes do campo hegemônico do desenvolvimento e cuja a participação no fenômeno estudado é fundamental tanto para a construção quanto para a disseminação destas políticas pelo sul global.

Ao longo da segunda metade da década de 1990 e início dos anos 2000 o BM esteve intrinsecamente envolvido no desenvolvimento dos programas de TDCR na américa latina. Atuou tanto no financiamento ${ }^{9}$, divulgação ${ }^{10}$ e avaliação do Oportunidades e do Bolsa Família.

Atualmente o Banco Mundial age para difundir este modelo de combate a pobreza por meio de publicações e empréstimos a países do sul global como Turquia e Filipinas (Stevensson et ali, 2013) Por se causa desse fluxo que hoje atinge mais de 40 países iremos argumentar que trata-se de uma difusão hegemonizante.

O segundo actante incluído nesta pesquisa foi o Ministério do Desenvolvimento Social e Combate a Fome do governo federal brasileiro. Esta instituição foi palco do embate ideológico cujo resultado foi a adoção do programa nacional de transferência de renda para o combate a pobreza - Bolsa Família - e o abandono do Fome Zero (PFZ).

Trata-se de um processo que representa mais do que a troca de um modelo de política pública, mas um movimento de incorporação de princípios de desenvolvimento social defendidos pelo Banco Mundial e o abandono de uma perspectiva de transformação mais ampla da sociedade pela garantia de direitos amplos - Programa Fome Zero.

A disputa teve curta duração e, antes do fim do primeiro ano de mandato do Presidente Lula, o PFZ assim como seu grupo político, foram relegados a segundo plano. O Brasil, com essa mudança, assumiu definitivamente o caminho defendido pelos agentes hegemônicos do desenvolvimento.

Apesar da adoção pelo Brasil dos princípios defendidos pelas AID, não podem consideralo como um mero intermediário. Pelo contrário, o PBF transforma os princípios

\footnotetext{
9 O Banco Mundial fez dois empréstimos ao programa Bolsa família, o primeiro em e o segundo em. Os valores destinados ao programa são respectivamente 572 milhões e 200 milhões (em dólares americanos)

10 O Banco Mundial não somente publicou diversos estudos e documentos sobre as TDCRs latino americanas mas financiou fóruns e encontros internacionais entre governos para troca de experiências e conhecimento.
} 
estabelecidos pelo Banco Mundial. O sucesso do programa brasileiro levou este modelo a ser adotado oficialmente pelo Banco. A agência do governo brasileiro, notadas a partir dos efeitos que este impôs a matriz global do desenvolvimento, é suficiente - de acordo com a teoria ator-rede - para elevá-lo ao status de mediador.

Assim, notamos que a agencia do Estado Brasileiro impacta de maneira decisiva no processo de construção do modelo contemporâneo de TDR para o combate a pobreza. O Brasil, na terminologia de Latour, assume o caráter de mediador que impacta e transforma as proposições do BM de acordo com seu espaço próprio de experiência.

Iremos argumentar adiante que se trata de um fluxo hegemonizado que trafega desde o actante subalterno em direção a um dominante. Isso pois, o Brasil adota a politica de proteção proposta por um agente institucional do norte capitalista e devolve um formato que, apesar de alterado, não representa um rompimento paradigmático com as propostas do BM.

Em paralelo a este processo o Brasil foi uma dos países envolvidos na intensificação das relações de cooperação sul-sul. As recentes crise financeiras de 2007/2008 e a fragilidade momentânea das economias do norte aceleraram ainda mais esse processo. Um dos resultados mais importantes desta aproximação foi criação de novos fóruns de diálogo a partir das novas alianças que se constituiram. Dois exemplos destes que contam com a participação do Brasil são o $\operatorname{IBAS}^{11}$ e o BRICS $^{12}$.

$\mathrm{Na}$ agenda destes fóruns os múltiplos aspectos do desenvolvimento social figuram em posição de destaque. São nestes espaços que o governo brasileiro promove o PBF como modelo de combate a pobreza, um dos mais importantes é O Grupo de Trabalho sobre desenvolvimento Social do IBAS.

\footnotetext{
${ }^{11}$ O IBAS é o fórum de dialogo entre Brasil, Índia e África do Sul iniciado em 2003 a partir do acordo de Brasília. O grupo atua em três frentes: 1) os fóruns para consulta e convergência em nível político; 2) os 16 Grupos de Trabalho que colaboram em áreas e projetos concretos; 3) e a assistência a outros países em desenvolvimento através do Fundo para Alívio da Fome e da Pobreza.

Entre os grupos de trabalho, o mais significativo para esta tese é o GT de desenvolvimento social. De acordo com as entrevistas realizadas no Ministério das Relações Exteriores do Governo Sul-africano as transferências de renda e o Programa Bolsa Família constituem um pauta chave do grupo.

${ }^{12}$ O BRICAS integra Brasil, Rússia, Índia, China e África do Sul. Apesar do caráter mais político e estratégico deste grupo formado diante da crise econômica dos países desenvolvidos, o Programa Bolsa Família já foi alvo de duas apresentações do Governo Brasileiro nos encontros anuais.
} 
Em busca de entender melhor as características e efeitos deste intercambio nos detivemos Índia e na África do Sul. A pesquisa revelou quadros muito diversos em cada caso.

A chegada do Congresso Nacional Indiano ao poder no ano de 2003 significou o marco inicial do processo de adoção das transferências de renda na Índia. Deste período até os dias atuais mudanças profundas foram introduzidas no sistema de proteção social do pais, entre elas: a alteração do cálculo da pobreza no país e a implementação de diversas experiências piloto de TDR foram com vistas a substituir, ao menos em parte, o sistema de subsídios e distribuição de alimentos.

A África do Sul, membro dos mesmos fóruns que Brasil e Índia, parecia apontar em uma direção diferente. Ao invés de adotar o modelo do Bolsa Família, o governo do país anunciou em 2012 a implementação de um programa de segurança alimentar inspirado no Programa Fome Zero do Brasil.

A escolha surpreendente um modelo derrotado pelo Bolsa Família no Brasil parecia indicar a existência no diálogo sul-sul um convívio de uma maior deiversidade modelos e princípios de proteção social. Poderiam as trocas de conhecimento entre agentes periféricos, ao contrário fluxo hegemonizante Norte-Sul, ser constituído de um troca de conhecimento e tecnologias sociais de caráter mais horizontal .

No Fome Zero as transferências de renda figuram como uma, entre muitas, ferramentas e estratégias de um plano amplo e ambiciosos de combate a pobreza. No entanto, como detalharemos abaixo, o plano foi abandonado e silenciado ao longo da realização desta pesquisa e encontra-se hoje no espaço dos discursos interditos do governo daquele país.

O quadro acima denota a existência de um terceiro fluxo que contribui para a difusão das TDCRs e se da a partir de, e em direção à actantes do sul global. Por sua particularidade não podem ser claramente definidos como hegemonizantes ou hegemonizados e nos dedicaremos a qualificar este fluxo de acordo com as evidências coletadas na conclusão da tese.

\section{Breve nota técnica sobre as fontes de pesquisa utilizadas}




\section{a) Banco Mundial.}

A abordagem ao BM se deu por meio da coleta de evidências e dados de múltiplas origens. No entanto, os documentos e publicações oficiais do Banco constituem a principal fonte de análise. Isto não significa uma submissão a história e ao discurso oficial desta instituição, mas de uma estratégia de busca no discurso do próprio sujeito de pesquisa de indicativos do envolvimento da instituição na adoção e difusão das TDRs como estratégia de proteção social indicada aos países do sul global.

Começaremos o capítulo sobre o Banco Mundial com um breve histórico que procurará mostrar: a) o processo de transformação da instituição em uma agencia de desenvolvimento, b) e o longo processo de ascensão da temática da pobreza na instituição e c) a incorporação das TDRs como estratégia de combate a pobreza.

Como principal referencias do sobrevoo histórico inicial foi utilizada a obra de Devesh Kapur, John Lewis e Richard Webb (Kapur et Al, 1997). Trata-se de publicação referencial que, ao mesmo tempo, é resultado de uma das mais detalhadas pesquisas sobre o a Instituição e, foi trabalho chancelado e financiado pelo próprio Banco Mundial.

Será por meio dos relatório e documentos da instituição que evidenciaremos o processo de adoção das redes de segurança como forma de proteção social, a relação do Banco com as TDRs e a incorporação do modelo latino americano de transferência de renda. Os seguintes documentos se mostraram os mais significativos para os objetivos propostos nesta tese:

1. 1991 World Development Report. Neste documento da instituição foram elaborados os critérios para os estabelecimento da primeira linha de pobreza baseada exclusivamente em renda.

2. 1993 Social Security Reforms and Social Safety Nets.

3. 2001 World Development Report: Attacking Poverty: Opportunity, Empowerment, and Security. Neste ano foram oficializadas pelo Banco Mundial a necessidade de implementação das redes de segurança.

4. 2003. World Bank Social Protection Strategy Paper: From Safety Net to Springboard 
5. 2004 World Development Report: Making Services Work For Poor People. Neste documento o Banco Assume as transferências condicionais de renda como principal modelo de proteção social.

6. 2006 World Development Report: Equity and Development. Banco abandona, influenciado pelos resultados do Bolsa Família a perspectiva restrita de que as redes de segurança deveriam se manter limitadas ao alívio emergencial.

7. 2006 Poverty and social impact analysis of reforms : lessons and examples from implementation. Texto que expõe o custo social da implementação das políticas de Ajuste Estrutural

8. 2007 The Nuts and Bolts of Brazil's Bolsa Família Program. Principal publicação do Banco Sobre o Programa Bolsa Família.

9. 2011. Social Safety Nets: An Evaluation of World Bank Support, 2000-2010. Relatório de avaliação das ações do Banco Mundial referente as redes de segurança.

Além destas publicações, o Banco Mundial disponibiliza em seu sítio virtual diversas bases de dados, tanto sobre os países clientes, como sobre as ações do Banco. Os dados utilizados nessa pesquisa são provenientes desta fonte, assim como dos relatórios anuais da instituição.

\section{b) O Modelo Latino americano de TDCRs e o Bolsa Família}

A análise do desenvolvimento das TDCRs na américa latina e do Bolsa Família, assim como a parte sobre o Banco Mundial tem caráter eminentemente histórico e descritivo.

Nesta parte o principal objetivo foi de apresentar o processo de construção desta estratégia de combate a pobreza e quais as particularidades que este formato incorpora. Para dar conta de tal meta, foi realizada pesquisa documental centrada principalmente em três fontes:

a) Literatura especializada. É farto o material acadêmico produzido a respeito do caso latinoamericano de TDCRs. Artigos e livros de caráter científico sobre o tema e, na medida do possível, estes foram incorporados a tese. 
b) Documentos do Estado Brasileiro. Muitas publicações de órgãos governamentais foram lançados desde a implementação do Bolsa Familia. Destaca-se as publicações do IPEA - Instituto de Pesquisa Econômica Aplicada e do MDS Ministério do Desenvolvimento Social e Combate a Fome sobre o assunto.

c) Publicações de organismos internacionais e organizações não-governamentais. Foi utilizado como material de consulta e pesquisa diversas textos, relatórios e estados realizados por entidades como o Banco Mundial e Organization for Social Development Initiatives (OSDI). Foi central a esta pesquisa o plano do Fome Zero publicado pelo Instituto Lula em que as linhas originais programa foram anunciadas.

\section{c) A Índia}

O trabalho de pesquisa na Índia contemplou dois objetivos. O primeiro foi o de construir um sobrevoo histórico sobre as políticas de desenvolvimento e combate a pobreza no país. O Segundo foi o de apresentar o caso corrente de implementação das Transferências de Renda como estratégia de combate a pobreza.

A pesquisa de campo realizada na Índia foi profundamente influenciada pela JNU, universidade em que me baseei ao longo do trabalho. A leitura da história econômica e de desenvolvimento indiano se filia a escola de pensamento crítico e marxista que marca a produção acadêmica da instituição. Em especial é preciso destacar o pensamento dos professores e pesquisadores, Bipan Chandra, Usta Patnaik e Jayati Ghosh.

Outra fonte importante de documentos foi a Indian Planning Comission. Esta instituição indiana, responsável pelo planejamento econômico nacional, é actante central na incoporação das TDCRs as políticas públicas do país.

Por fim também foram fundamentais a esta pesquisa os documentos de organismos internacionais e ONGs que avaliam as primeiras experiências de transferência direta de renda no país. 
Parte II - Contexto e processo histórico do surgimento e aperfeiçoamento das Transferências Diretas de Renda. 


\section{Capítulo 2 - As transferências diretas de renda.}

\section{Apresentação}

Antes de partirmos para a descrição dos atores envolvidos na pesquisa de campo, nos deteremos a uma breve caracterização das Políticas de Transferência de Renda. Neste tópico iremos a) descrever o processo histórico de desenvolvimento desta estratégia de política publica e b) constituir uma tipologia para tais políticas.

As TDRs são políticas publicas redistributivas de caráter não contributivo, em que o governo transfere renda de forma direta aos beneficiários do programa. Ou seja, ao contrário, de pensões, aposentadorias e seguro desemprego, as Transferências Diretas não são condicionadas a pagamentos ou contribuições prévias por parte dos beneficiários.

De acordo com Driusso (2010), existem dois formatos de transferência de renda aplicados ao combate a pobreza, cujas diferenças são fruto de percepções divergentes sobre as causas deste fenômeno no sul e no norte global.

No norte global, a visão contemporânea sobre a pobreza se ergue sobre princípios definidos pelo iluminismo francês e norte-americano (Jones, 2004). Autores como Paine e Condorcet dedicaram parte importante de sua obras a este tema e produziram tanto uma leitura singular da pobreza como soluções para combater este problema. Por esta característica, são considerados por Jones como os mais relevantes para a configuração do pensamento europeu sobre o tema. 
Condorcet entendia a pobreza como um fenômeno resultante da imperfeição passageira da arte do social. Já Paine dizia que a causa do problema era o acesso desigual aos recursos naturais de uma nação (Driusso, 2010). Tal restrição constituía uma afronta ao direito natural a igualdade advinda do avanço da propriedade privada.

Apesar das diferenças, ambos percebiam a pobreza como uma consequência negativa, mas passageira, do avanço moderno. Este otimismo se fundamenta na inabalável crença no progresso como caminho para a emancipação humana.

Para os objetivos desta pesquisa é importante destacar que a pobreza, na visão destes autores, é um fenômeno que atinge os cidadãos em seus direitos humanos fundamentais. Esta aspecto justifica, sob esta perspectiva teórica, a necessidade de intervenções públicas com o objetivo garantir a condições de igualdade infringida pelas imperfeições advindas do modelo societal moderno. Sobre este alicerce teórico surgiram as políticas de Garantia de Renda Mínima - GRMs estratégia atualmente em vigor em quase todos os países europeus da união europeia. (Busilacchi, 2010)

As GRMs são transferências diretas de renda cujo o objetivo é garantir um nível mínimo de renda para garantir a subsistência de todos os cidadãos, justificado pela de compensação a desigualdade entre os membros da sociedade. (Driusso, 2010) São portanto políticas amplas estabelecidas na legislação como um direito.

Já no sul global, a pobreza é vista como um fenômeno originado pela ausência de progresso ou atraso civilizacional. (Driusso, 2010). Assim, na periferia do sistema-mundo atual, a condição de pobreza está desconectada da expropriação de direitos fundamentais, sendo atribuída ao atraso material, científico e cultural destes territórios. O próprio projeto hegemônico do desenvolvimento é uma evidência desta diferença de abordagem ao tema no norte e no sul global, uma vez que, como veremos adiante, as transferências diretas condicionais de renda propõem justamente moldar as atitudes das famílias de baixa renda como forma de superação da pobreza.

O progresso, visto como causa da pobreza no norte, é alçado ao status de solução para as nações do sul global. Assim, o termo pobreza parece referir-se a fenômenos completamente diversos no centro e na periferia do sistema mundo. Enquanto no norte se trata de questão situada na esfera do direito, na periferia é percebido como condição de incompletude. 
Esta visão do sul global como atrasado em relação ao norte, não fundamenta somente a percepção da pobreza, mas está na base tanto da narrativa colonial quanto do projeto do desenvolvimento. (Esteva, 2010 e Sklair, 2005) Sob esta discurso se justifica a necessidade da ampla gama de intervenções de caráter civilizatório nas nações periféricas, cujo o objetivo é o de promover avanços em direção ao modelo societal do centro hegemônico do sistema mundo atual.

As transferências diretas de renda no sul global estão embasadas nesta ótica. São ações focalizadas que não visam a garantia de direitos sociais amplos a todos os cidadãos, mas garantir alívio de situações extremas enquanto o processo de desenvolvimento não se completa.

Os primeiros exemplos de TDRs no sul global foram implementados como ações paliativas aplicadas a situações de catástrofe ou emergência e estavam voltados a uma ampla gama de problemas sociais. TDRs especificamente direcionadas ao combate a pobreza só foram desenvolvidos ao longo da década de 1990, momento em que o Banco Mundial passa a promover a instalação de redes de segurança para lidar com os efeitos sociais negativos dos ajustes estruturais.

Ao longo da segunda metade da década de 1990 formatos mais complexos de TDRs voltados diretamente ao combate a pobreza foram desenvolvidos na América Latina. Nestes casos, foram agregadas as ações de alívio emergencial, objetivos mais amplos que buscavam gerar efeitos de longo prazo por meio do investimento no capital humano das famílias pobres. A particularidade destes programas é a exigência de contrapartidas a seus beneficiários o que faz destes um modelo específico TDR: as Transferências Diretas Condicionais de Renda - TDCRs ${ }^{13}$.

O programa Bolsa Família do Brasil e o programa Oportunidades do México são os exemplos mais importantes de TDCR. Pela lógica destas políticas, o investimento em capital humano por meio de condicionalidades de educação e saúde, induz o

\footnotetext{
${ }^{13}$ O Banco Mundial no Development Report de 2009, define as TDCRs da seguinte maneira: "Conditional cash transfers (CCTs) are programs that transfer cash, generally to poor households, on the condition that those households make prespecified investments in the human capital of their children. Health and nutrition conditions generally require periodic checkups, growth monitoring, and vaccinations for children less than five years of age; perinatal care for mothers and attendance by mothers at periodic health information talks. Education conditions usually include school enrollment, attendance on 80-85 percent of school days, and occasionally some measure of performance. Most CCT programs transfer the money to the mother of the household or to the student in some circumstances." (Behrman e Calderón, 2009)
} 
desenvolvimento de um maior leque de capacidades ${ }^{14}$ aos membros das famílias pobres e a quebra de ciclos geracionais de pobreza.

As TDCRs expressam como poucas políticas publicas a visão de que a pobreza é fenômeno de falta ou incompletude, devendo então ser combatida por meio de estímulos para a superação de tal condição.

As TDRs, portanto, não se erguem sobre uma perspectiva ideológica da igualdade e do direito cidadão de acesso a riqueza da nação, como as GRMs. São estratégias cujo principal objetivo é o de fornecer alívio a uma situação transitória e emergencial de povos subdesenvolvidos e investir em capital humano na esperança de promover o avanço destas populações em direção a uma vida moderna e quebrar a reprodução social do fenômeno da pobreza.

\section{As Garantias de Renda Mínima e a pobreza no Norte}

As Garantias de Renda Mínima são transferências diretas de renda que procuram redistribuir a riqueza nacional de maneira a prover um padrão mínimo de subsistência e constituem direito acessível a todos cidadãos em condição de pobreza. Esta prática a principal estratégia de combate direto ao fenômeno da pobreza dos países do norte global.

Na Europa, o modelo de GRM mais adotado, se configura por depósitos mensais aos que se encontram abaixo da linha nacional de pobreza. A variante Norte Americana de garantia de renda mínima é o chamado imposto negativo, no qual a transferência de renda ocorre apenas no momento da declaração anual de renda.

Os princípios sobre os quais se erguem as políticas de garantia mínima vem, como resumimos acima, do Iluminismo. No entanto, de acordo com Jonas (2004) e Driusso (2010), foi em 1516, na obra Utopia de Thomas Morus, que se registra a primeira ruína teórica da visão moderna a respeito da pobreza. (DRIUSSO, 2010 e JONES, 2004) O trecho abaixo ilustra a visão do autor:

\footnotetext{
${ }^{14}$ A ideia de capacidade que está imbuída ideologicamente nas TDCRs tem origem na perspectiva de Amatya Sen, um dos autores cujo o pensamento foi decisivo para a formulação deste modelo de política pública. $O$ autor define a relação entre pobreza e capacidade da seguinte maneira:
} 
"Neste caso, a morte é uma pena injusta e inútil; é bastante cruel para punir o roubo, mas bastante fraca para impedi-lo. O simples roubo não merece a forca, e o mais horrível suplício não impedirá de roubar o que não dispõe de outro meio para não morrer de fome. (...) Fazeis sofrer aos ladrões pavorosos tormentos; não seria garantir a existência a todos os membros da sociedade, a fim de que ninguém se visse na necessidade de roubar, primeiro, e de morrer depois?" (MORE, 1516, p.27). (Morus, apud Driusso, 2010:84)

Morus se questiona sobre a necessidade de garantir a subsistência dos membros da sociedade com o objetivo de evitar problemas sociais advindos da situação de pobreza. (Driusso, 2010: Suplicy, 2008) Mesmo sem oferecer muito mais do que uma leitura ensaística ou literária da questão, esta ideia inspirou em 1526 Juan Luis Vivis a formular a primeira proposta concreta de GRM na Europa.

Em seu livro De Subventione Pauperum Sive de Humanis Necessitabus, Vivis propõem aos governantes de Gênova garantir a subsistência de seus habitantes, o que nunca chegou a acontecer. No entanto, cidades como Ypes na Bélgica e as Leis dos Pobres adotadas nos Países Baixos em 1531 e na Escócia em 1579 tem no pensamento Vivis uma de suas principais referências. (Driusso, 2010)

It was in the I79os at the time of the French Revolution that there first emerged the believable outlines of a world without endemic scarcity, a world in which the predictable misfortunes of life need no longer plunge the afflicted into chronic poverty or extreme want. This idea was not another version of the medieval fantasy of the land of Cockaigne, in which capons flew in through the window ready-cooked. Nor was it the update of a more serious invention, Utopia, most famously that created by Sir Thomas More in 1516 . (Jones, 2010:17)

Como afirma Jones (2010), o pensamento iluminista francês dá um salto em relação a visão idealista de Morus e das demais fantasias medievais. Isso pois foram estes autores que formulam de maneira mais estruturada a percepção moderna sobre as origens e soluções para a pobreza. Para tal baseiam-se na objetificação do social e no caráter emancipatório do progresso científico e tecnológico.

Para autores como Thomas Paine e Condorcet, a razão e o progresso são tanto a causa como o caminho para a superação da pobreza. O enfrentamento deste fenômeno pelas nações modernas passaria pela garantia do direito fundamental da igualdade: 
Against those who maintained that the gulf between rich and poor was an inescapable part of 'civilisation', Condorcet argued that inequality was largely to be ascribed to 'the present imperfections of the social art'. 'The final end of the social art' would be 'real equality' - 'the abolition of inequality between nations' and 'the progress of equality within each nation'. Ultimately, this progress would lead to 'the true perfection of mankind'. (Jones, 2010:18)

A pobreza, de acordo com Condorcet, é fenômeno derivado da imperfeição da arte do social. As nações modernas ainda não se encontravam completamente desenvolvidas e nem organizadas racionalmente. $\mathrm{O}$ aperfeiçoamento do desenho do social levaria a "humanidade perfeita" em que a pobreza deixaria de existir. Podemos inferir desta proposição que a sociedade é passível de controle racional e e sua captura total representaria a condição para emancipação humana.

O iluminista francês delineia uma proposta para solucionar o problema. Segundo ele, era necessário a implementação de uma estrutura previdenciária aliada a um sistema público de educação. A primeira garantiria um sistema de proteção social e a segunda contribuiria para diminuir as imperfeições da sociedade.

But such inequality could be 'in great part eradicated'. People in old age could be guaranteed a means of livelihood 'produced partly by their own savings and partly by the savings of others who make the same outlay, but who die before they need to reap the reward'. A similar principle of compensation could be applied by securing for widows and orphans 'an income which is the same and costs the same for those families which suffer an early loss and for those who suffer it later'. Through the application of the same principle, it would also be possible to provide all children with the capital necessary for the full use of their labour at the age when they started work and founded a family. (Jones, 2004:20)

O livro Agrarian Justice de Thomas Paine, publicado no ano de 1795, é uma das obras referenciais do iluminismo sobre a pobreza. (Jones, 2004 e Driusso, 2010) Ao longo do texto o autor atribui a origem deste fenômeno a crescente restrição de acesso a terra e matérias primas imposta pelos avanços das sociedades modernas.

Sua visão foi fundamentada em observações de populações nativas norte-americanas, nas quais ele constatou a inexistência do fenômeno da pobreza. Paine, afirma que esta condição é possível devido compartilhamento dos recursos naturais disponíveis. Diante da propriedade privada da terra, os cidadãos nascem em condição de desigualdade fator que deve ser corrigido para reestabelecer a justiça social do estado de natureza. 
Paine, portanto, se distancia de Condorcet, ao afirmar que a pobreza não é resultante apenas da imperfeição da arte do social, mas é condição estrutural do modelo societal moderno. Diante desta perspectiva, o autor advoga a necessidade de compensar os destituídos do direito natural de acesso as riquezas de sua nação. (Driusso 2010; Paine 1974; Spence e King 2006; Jones, 2004).

\begin{abstract}
The practical application of such a scheme in England, in the shape of a detailed set of proposals to replace the Poor Rate by a taxbased system of universal insurance, was set forth in the second part of Tom Paine's Rights of Man, published in February 1792. A more redistributory variant of the same idea was argued in his later pamphlet Agrarian Justice, which appeared in England in 1797. (Jones, 2004: 23/24)
\end{abstract}

Em termos concretos, Paine propõem a criação de um fundo público alimentado por recursos de contribuições obrigatórias impostas aos proprietários de terra. (Driusso, 2010) O valor acumulado deveria ser redistribuídos de maneira a compensar os que se encontravam alijados do acesso as riquezas da nação.

Henry George, seguidor das ideias de Paine, propõem uma solução ainda mais intensa. Segundo ele, para acabar definitivamente com o problema da pobreza era necessário abolir completamente a propriedade privada, como afirma Jones:

On the basis of his experiences in California, Henry George attacked Malthus, holding that the unearned increment of the landlord was responsible for the poverty of the masses. As soon as practicable, he argued, the land must be made common property, while in the interim a single tax should be imposed upon land values. Not only did his book sell over 100.000 copies but, in several tours of Britain in the early 1880 s, his powerful oratory left a lasting impact. (Jones, 2004: 208)

A visão de George mostra que as formulações iluministas comportam tanto políticas publicas compensatórias quanto as perspectivas revolucionárias dos setores políticos da esquerda europeia.

Se por um lado notamos a divergência sobre as causas do fenômeno da pobreza entre Paine (avanço da propriedade privada) e Condorcet (arte do social), por outro, ambos compartilham da fé no progresso como um caminho para a resolução desta questão. Os dois autores promovem a visão de que o desenvolvimento humano baseado na ciência e na razão levaria a constituição de uma sociedade sem imperfeições. 
Concretely, and in the words of English subject turned 'citizen of the world' Tom Paine, it would be a society in which 'we' no longer 'see age going to the workhouse and youth to the gallows'; one in which orphan-hood, single parenthood, unemployment, sickness, old age or the loss of a breadwinner would be relieved by right. (Jones, 2004:17)

As Garantias de Renda Mínima - GRM se constituíram como a principal estratégia de política pública resultantes desta visão eurocêntrica sobre o problema da pobreza. Isso pois almejam prover um mínimo para a substancia dos grupos pauperizados a partir das contribuições dos mais abastados.

Estas políticas foram inseridas nas legislações nacionais como direitos humanos de caráter universal. (Busilacchi, 2010) Ou seja, todos os indivíduos em condição de pobreza possuem o direito ao benefício, pois trata-se de um fenômeno de causas estruturais e não uma deficiência individual

As primeiras experiências de GRMs podem ser traçadas ao meio do século XIX e diferentes formatos da mesma estratégia seguiram sendo implementadas e desenvolvidas até a década de 1990. (Driusso, 2010). Os exemplos mais recentes da adoção de políticas deste tipo foram: Dinamarca 1937, Reino Unido em 1948, Alemanha em 1961, Holanda em 1963, Bélgica em 1974, Irlanda em 1977, Luxemburgo em 1986, França em 1988, Espanha em 1990 e Portugal em 1997. (Suplicy, 2008)

Com base nos mesmos princípios, os Estados Unidos da América implementaram o Earned Income Tax Credit - EITC no ano de 1975. Trata-se de um sistema de taxação negativa em que uma transferência anual é feita as famílias pobres no momento da declaração de renda. Trata-se também de uma política redistributiva, não focalizada e de caráter compensatório

Em 1982, o estado do Alasca adotou política pública muito próxima da proposta de Thomas Paine. Neste ano, foi implementado o Fundo Permanente do Alasca, no qual são captados recursos de empresas petroleiras e redistribuídos ao moradores do estado como compensação a exploração dos recursos naturais.

As políticas de GMR encontraram seu momento de maior expansão no contexto do Estado do Bem Estar. O desmonte deste sistema nos anos 1990 impuseram cortes e transformações a estes esquemas de proteção social, mas, mesmo assim, a maioria dos países europeus mantém até os dias atuais algum formato de GRM.(Soares, 2010) 
In long-ago 1992, the European Community emphasised this obligation for all the countries of the old continent. Today, discussion on a stronger European social model and the undertaking of actions against poverty, and framework programmes for active social inclusion policies (Lisbon 2000), have relaunched the theme. It is therefore no coincidence that, in many countries, debate has resumed on how to guarantee a minimum income for all citizens. Particularly in Italy, which together with Greece and Hungary is the only case in the 27member state European Union of a welfare state which does not have a specific minimum income policy, the discussion has recently been accompanied by numerous proposals. (Busilacchi, 2010:2)

A citação mostra que a importância atual das GRMs para as políticas sociais da União Europeia. Os países membros são obrigados a adotar, pelo tratado de lisboa, a adotar esquemas de Garantia de Renda Mínima para o combate a pobreza no continente. (Busilacchi, 2010)

\section{Pobreza no sul global e as Transferências Diretas de Renda.}

O cenário nas ex-colônias é bem diferente. Nestes espaços, a pobreza não é percebida pela ótica do direito econômico e da garantia da igualdade, mas pela ausência de desenvolvimento. Por este motivo o combate a este problema não tem caráter compensatório, mas civilizatório.

No sul global, ações governamentais concretas e diretas contra a pobreza só foram implementadas ao final do século XX. (Soares, 2010) Tal fato é um indício da leitura que esta condição é resultante da falta de progresso e sua superação seria atingida pelo crescimento econômico e modernização dos sistemas produtivos. Como afirma Soares sobre o caso Brasileiro:

no Brasil a pobreza não se configurava tema ausente das preocupações e reflexões sobre o país e seu futuro. Mas, formulada como sinal de atraso e como tributo do passado, foi, durante décadas, interpretada como paisagem, ou seja, como aquele elemento que permanente, quase imutável, e secundário, não merecia tratamento específico. Seu enfrentamento seria paulatinamente realizado com o avanço do progresso e do crescimento econômico. (Ipea, 2010:101) 
Este discurso implica que, para lidar com os problemas sociais dos países do sul global, devem buscar alcançar o modelo societal do norte capitalista. Tal pensamento representa o progresso como um processo linear - construída com base em uma versão eurocêntrica do desenvolvimento europeu e estadunidense - é alçada a condição de caminho universal de emancipação.

Desde o início da era do desenvolvimento, diversos caminhos para a superação do subdesenvolvimento, e portanto da pobreza, foram defendidos pelas agencias internacionais, entre eles: o investimento em infraestrutura de transporte, a industrialização e a liberalização.

De acordo com Pereira (2010), a centralidade da temática da pobreza nos países do sul global só vai ocorrer a partir de uma nova direção ideológica do Banco Mundial que começou a ser desenhada nos anos 1970. Como afirma o autor:

\begin{abstract}
Historicamente, a carteira de empréstimos do Banco Mundial funcionou como instrumento para fazer circular, internalizar e institucionalizar o produto principal: ideias econômicas e prescrições políticas sobre o que fazer, como fazer, quem deve fazer e para quem em matéria de desenvolvimento capitalista, nas suas mais variadas dimensões. A construção político-intelectual do "combate à pobreza" fez parte dessa trajetória a partir do final dos anos sessenta. Após duas décadas alimentado por empréstimos, assistência técnica a governos, articulações com outras agências de desenvolvimento e milhares de publicações promovidos pelo Banco Mundial, o enfoque orientado à pobreza terminou por impor em âmbito internacional, no bojo dos programas de ajustamento estrutural, uma maneira específica de se pensar e se fazer política social, baseada na separação teórica entre produção da pobreza e produção da riqueza e na noção de mínimos sociais. Não se entende como uma mudança política e intelectual dessa envergadura foi possível se não se tem em conta a atuação financeira e não-financeira do Banco Mundial. (Pereira, 2010:276)
\end{abstract}

A introdução deste tema na agenda do BM foi acompanhada de um processo paulatino de aumento dos recursos destinados a combater a pobreza. Caminho que culmina com a elevação da questão a posição central no discurso do Banco.(Pereira 2010)

Esta transformação em direção ao combate a pobreza, cujo participação do Banco Mundial detalharemos no próximo tópico, não significou uma defesa por parte da instituição de modelo de proteção baseado em garantias de direitos. Pelo contrário, o BM e os estados periféricos passaram neste momento a implementar programas focalizados de alívio a condições de extrema pobreza. Inicia-se neste período o processo que ira levar as 
Transferências Diretas de Renda a serem estabelecidas como estratégia para o combate a pobreza no sul global promovida pelo Banco Mundial.

In Latin America, cash transfer programmes emerged in response to concerns about increasing inequality and the negative effects of structural adjustment programmes and accompanying economic crises. (UNRISID, 2009:22)

A sistematização de um modelo de combate a pobreza ocorreu em reação as crises causadas pela imposição dos chamados ajustes estruturais aos países do sul global. Sob égide da hegemonia neoliberal, o BM se aproveitou da fragilidade econômica nos países periféricos e a consequente dependência destas nações de recursos externos ao longo anos 1980 e 1990 para exigir contrapartidas a concessão de empréstimos.(George e Sabelli, 1994 e Kapur, 1997). O impacto social destes ajustes foi negativo com aumento da desigualdade e o agravamento da pobreza por todo o mundo. Como podemos notar nas palavras de Calvo (2011) sobre a américa latina:

According to Londono and Szekely (1997), in Latin America from 1982 to 1993 the overall number of people living in poverty increased from 78 to 150 million. Despite small improvements, overall poverty levels have remained as those attained in 1980 (136 million people). (Calvo, 2011:54)

Um dos primeiros exemplos de TDR implementado neste período foi o GAPVU ${ }^{15}$, iniciado em Moçambique no ano de 1990 e com o objetivo exclusivo de aliviar a situação emergencial de pobreza das famílias aglomeradas nas periferias de Maputo. (Datt et all, 1997)

É importante destacar, que a aplicação das TDRs não ficou restrita a redução da pobreza. Foram implementadas experiências voltadas a uma variedade de questões sociais como a saúde, educação e trabalho infantil. Até os dias atuais TDRs seguem sendo utilizadas em situações emergenciais como fez o estado Indonésio após a catástrofe causada por uma Tsunami em 2007 (Harvey, 2010).

A importâncias das TDRs não se assenta em formato inovador, uma vez que estratégias semelhantes foram usadas de maneira não sistemática antes da adoção pelo Banco Mundial. Dreze e Sen (2007), por exemplo, afirmam ter encontrado casos de transferências diretas de renda no período colonial indiano durante grande fome em West Bengal de

\footnotetext{
${ }^{15}$ Gabinete de Apoio a Poulação Vulnerável
} 
1943. Ghosh, por sua vez, afirma que TDRs já eram utilizadas reinados islamicos da idade média (Ghosh, 2011).

Estas experiências pré-1945, embora importantes, não se enquadram no fenômeno que interessa a esta tese. Buscamos aqui evidenciar um processo especifico e sistemático de difusão gerada a partir da adoção das TDRs como política de combate a pobreza pelo Banco Mundial.

Nos interessa, portanto, entender as TDRs como parte de configuração singular da matriz de agentes do desenvolvimento sobre a qual um processo de difusão se estabeleceu. Procuraremos caracterizar esta disseminação como um fluxo hegemonizante, pois tal movimento é condicionado por relações de subordinação entre os agentes do Norte e do Sul global.

Não existem referencias seguras de quantos programas de TDR se encontram em funcionamento atualmente. Isto pois, existem experiências regionais e nacionais e uma imensa variedade nos formatos e objetivos para qual estas políticas são direcionadas.

Um indicativo mínimo sobre a dimensão do fluxo a qual nos referimos, foram os mais de $100^{16}$ diferentes programas implementados pós 1990 , em países do sul global e voltados aos mais diversos problemas sociais mencionados na bibliografia consultada por esta tese. Apesar da especificidade de cada país, podemos separar as TDRs em dois tipos gerais: a) as Incondicionais - TDIR - e b) as Condicionais TDCRs.

As TDIRs são, em sua maioria, utilizadas em situações específicas ou emergenciais. Normalmente são ações de curto ou médio prazo, focalizados em públicos muito específicos e tem o objetivo de propiciar o alívio imediato de condições de vulnerabilidade.

Poucas são as experiências de TDIR voltadas exclusivamente a redução da pobreza. O exemplo de Moçambique, acima citado, é um dos poucos casos encontrados ao longo da pesquisa. No entanto, o caminho que a Índia parece hoje trilhar, como veremos a frente, aponta para a adoção do modelo de transferência sem condicionalidade.

\footnotetext{
${ }^{16}$ Para chegar a este número foram somadas as transferências diretas de renda citadas nos documentos consultados do Banco Mundial, DFID, ODI, UNICEF, PNUD, OMS, UNRISID e artigos científicos sobre o tema. Estão incluídos os programas de curto e longo prazo. Em alguns casos, como o do Brasil, existe mais de um programa de TDR iniciado desde a década de 1990.
} 
As Transferências Condicionais de Renda, por sua vez, caracterizam-se por exigir contrapartidas ao beneficiários em troca das transferências. Estas condicionalidades foram introduzidas com o intuito de estimular mudanças de atitudes, hábitos e praticas dos beneficiários. O quadro abaixo resume os tipos acima descritos:

Tabela 1 - Tipologia das Transferências Diretas de Renda

\begin{tabular}{|c|c|c|c|}
\hline Modelo Geral & Características Gerais & Formatos específicos: & $\begin{array}{c}\text { Características } \\
\text { Específicas }\end{array}$ \\
\hline \multirow[b]{2}{*}{$\begin{array}{l}\text { Transferências } \\
\text { Diretas de Renda } \\
\text { - TDR }\end{array}$} & \multirow[b]{2}{*}{$\begin{array}{l}\text { Políticas não contributivas } \\
\text { Constituem parte do modelo } \\
\text { de proteção social baseado } \\
\text { em redes de segurança } \\
\text { Defendido pelo Banco } \\
\text { Mundial a partir das crises } \\
\text { causadas pelos ajustes } \\
\text { estruturais } \\
\text { Não se constituem como } \\
\text { direito amplo e sim } \\
\text { programa social focalizado }\end{array}$} & $\begin{array}{l}\text { Transferências } \\
\text { Incondicionais de Renda }\end{array}$ & $\begin{array}{l}\text { Procuram promover o } \\
\text { alívio de situações } \\
\text { emergenciais. } \\
\text { Poucos programas } \\
\text { voltados a pobreza }\end{array}$ \\
\hline & & $\begin{array}{l}\text { Transferências } \\
\text { Condicionais de Renda }\end{array}$ & $\begin{array}{l}\text { Procuram promover alívio } \\
\text { emergencial } \\
\text { investimentos no capital } \\
\text { humano das famílias } \\
\text { beneficiárias. } \\
\text { Embora tenha sido } \\
\text { aplicado a diversos } \\
\text { problemas sociais, seu uso } \\
\text { mais recorrente é no } \\
\text { combate a pobreza } \\
\text { O modelo de TDCR } \\
\text { desenvolvido na America } \\
\text { Latina foi adotado pelo } \\
\text { Banco Mundial }\end{array}$ \\
\hline
\end{tabular}

As primeiras experiências com TDCRs, embora concentradas na América Latina, se espalham por diversas partes do mundo. Na Índia, por exemplo, o ApniBeti Apna Dhan (Our Daughter, Our Wealth) foi implantado no estado de Haryana em 1994. Pelas regras deste programa de TDCR, o governo local se encarregava de abrir uma poupança para as filhas das famílias beneficiárias e realizar um depósito mensal até esta atingir 18 anos. No entanto, o valor recebido só pode ser sacado pelas famílias caso esta ainda não se encontrasse casada. $\mathrm{O}$ objetivo era diminuir matrimônio forçados de meninas menores de 18 anos provendo uma alternativa ao tradicional dote dado a família da noiva.

Em meados da década de 1990, em paralelo a experiência indiana, TDCRs foram implementadas por toda a América Latina constituindo o início do processo que levará a 
um modelo voltado diretamente a redução da pobreza. O programa Oportunidades do México, herdeiro do Progressa iniciado em 1996, e o Bolsa Família do Brasil, implementado 2004 a partir de um conjunto de programas menores, são os dois programas mais significativos que resultam deste processo. (Kiggundu 2012; Rodrigues 2010; Sugiyama 2011) 
Figura 4 - Expansão das TDCRs apoiadas pelo Banco Mundial ${ }^{17}$

1997

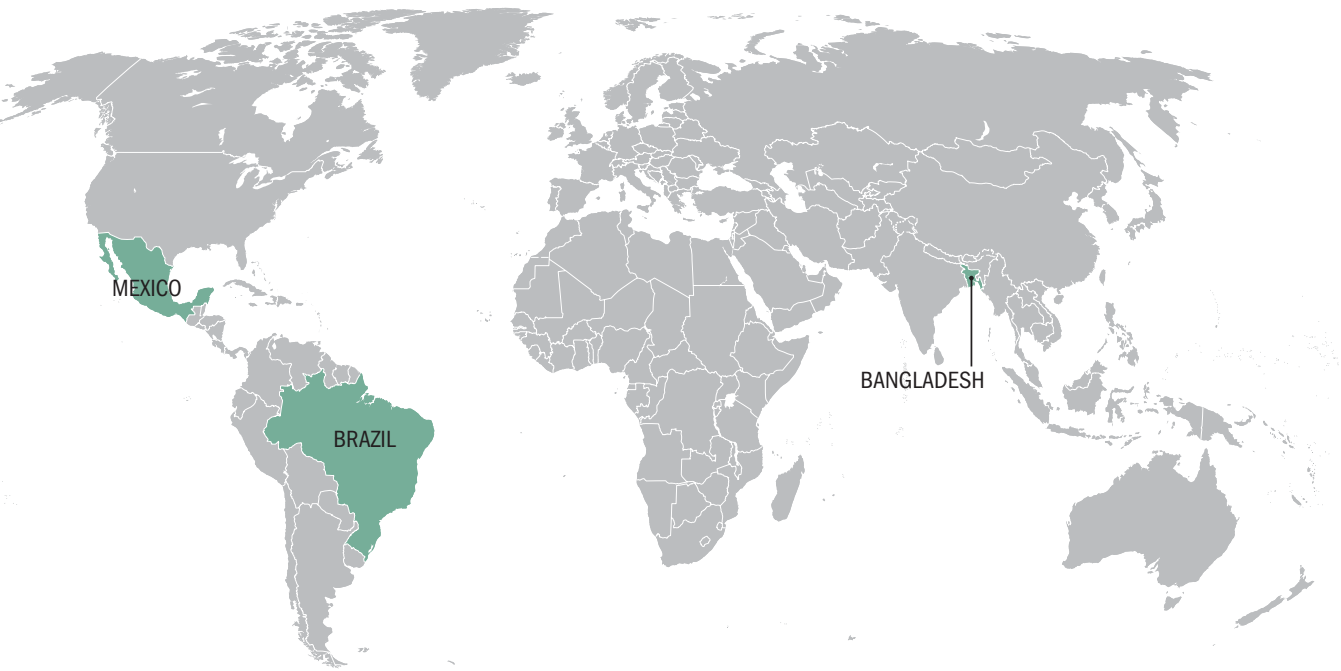

\section{8}

${ }^{17}$ Fonte: World Bank (2009:32) 


\section{Capítulo 3 - O surgimento do modelo Latino Americano de Transferências Diretas Condicionais de Renda.}

\section{Apresentação}

Este capítulo tem como principal objetivo descrever o modelo latino americano de transferências diretas condicionais de renda. Para atingir essa meta, focalizaremos o caso brasileiro do Bolsa Família por este ser um dos dois programas mais completos da região. Além disso, o PBF é, juntamente com o Oportunidades do México, o modelo adotado e promovido pelo Banco Mundial.

A descrição do Bolsa Família foi dividida em duas partes, a primeira se detem no processo que levou até a instalação do programa e o segundo detalha o formato atual da política Nos deteremos também, de forma breve, ao Programa Oportunidades do México com o objetivo de demonstrar a proximidade desta política com o Programa Bolsa Família. Os demais programas serão citados de maneira a evidenciar a difusão deste modelo.

Das primeiras experiências à consolidação do Bolsa Família 
No caso do Brasil, o processo de desenvolvimento de um programa nacional de transferência condicional de renda para o combate a pobreza remonta ao primeiro mandato de Fernando Henrique Cardoso, iniciado em 1994.

Tudo começou em 1995. Naquele ano, três experiências locais de renda mínima apareceram simultaneamente no Brasil: o Programa de Garantia de Renda Familiar Mínima, em Campinas, que teve início em março de 1995; o Bolsa Familiar para Educação, no Distrito Federal, que teve início em maio de 1995; e o Programa de Garantia de Renda Familiar Mínima, de Ribeirão Preto, que teve início em dezembro de 1995 (Ipea, 2011:29)

O contexto ideológico do momento era de hegemonia absoluta dos valores e pensamento neoliberal. Se estabelecia no país um debate nacional sobre o formato de proteção social a ser adotado para lidar com o grave quadro social brasileiro. De um lado o Governo federal brasileiro condicionado pelos compromissos internacionais assumidos. Por outro as forças progressistas de esquerda que defendiam um modelo de GRM baseado nas experiências europeias.

No entanto, a fragilidade econômica brasileira daquele período, herdada do profundo endividamento ocorrido ao longo da década de 1970 e intensificada pelos fracassos econômicos dos dois governos anteriores ao de FHC, se mostrou fator central para a redefinição do modelo de proteção nacional. Tais condições econômicas negativas são a causa da grande dependência de recursos externos providos pelas agencias internacionais que o país se encontrava naquele momento. Junto com os empréstimos vieram também a obrigatoriedade de promover ajustes estruturais.

Diante da impossibilidade de conciliar os compromissos assumidos externamente com as demandas internas por um programa nacional de GRM, o governo federal, em uma tentativa estabanada de descentralização, transferiu o combate a pobreza aos municípios. Estes foram então autorizados a implementar políticas locais de renda mínima. A experiência mais significativa foi o programa Renda Minha da Cidade de São Paulo.

There was a strong influence on them of the discourse attached to Senator Eduardo Suplicy's Guaranteed Basic Income proposal, but unlike the proposal, most of them were targeted and had a set of conditionalities attached to them. (Soares, 2011:56)

Em 1998 diante da ausência de recursos necessários a constituição de GRM na grande maioria das cidades brasileiras foi aprovado o projeto (Soares, 2011) do Senador 
Oposicionista Eduardo Suplicy do partido dos trabalhadores que implementou o Programa Nacional de Renda Mínima (Soares, 2011). Esta lei autorizava o Governo Federal a contribuir com os programas de GRM municipais. No entanto, em termos práticos, poucos recursos foram de fato destinados a este fim.

A vontade do governo federal prevaleceu e os problemas sociais passaram a ser enfrentados por meio das TDCRs, desde então agrupadas sob uma estrutura guarda-chuva chamada "comunidade solidária". Procurava-se dar forma a uma versão nacional do modelo de proteção social por meio de políticas que formariam uma rede de segurança em acordo com as proposições do Banco Mundial. Duas características podem ser destacadas sobre a transformação nas políticas sociais adotadas no período:

a) A consolidação das linhas de renda como critério de focalização das políticas sociais, como afirmam Silva, Yazbek e Giovanni (2010):

os anos 1990 representam um período de profunda contradição no campo do bem- estar social no Brasil. Tem-se, de um lado, um avanço no plano político-institucional, representado, sobretudo, pelo estabelecimento da Seguridade Social e dos princípios de descentralização e de participação social [...] de outro lado, tem-se, no plano da intervenção estatal no social, um movimento orientado por posturas restritivas, com a adoção de critérios de maior rebaixamento do corte de renda para fixação da linha de pobreza, para permitir acesso das populações, por exemplo, a Programas de Transferência de Renda em grande expansão no Brasil (Silva et Al 2004, apud Tessarolo p. 26).

b) Abandono da modelo de proteção social por meio de políticas perenes que instituem direitos amplos e universais. Como podemos perceber pelas palavras de Silva et all:

substituindo o princípio de universalização dos mínimos sociais, preconizado pela LOAS, por um princípio estreito de focalização, longe de representar discriminação positiva. Sua atuação, portanto estava em contradição com os fundamentos de direitos sociais estabelecidos pela Constituição (universalidade, qualidade e gratuidade). (Silva et Al 2004, apud Tessarolo p. 84)

Como afirma Yasbek (2004), estas transformações despertaram intensas criticas e o embate entre as forças progressistas e neoliberais no país. Os defensores das políticas universais denunciavam a submissão do país as exigências do ajuste estrutural e o governo insistia na necessidade de mudanças para sanar as contas nacionais. 
Esta lógica, que subordinou políticas sociais aos ajustes econômicos e às regras do mercado, moldou para a política social brasileira um perfil despolitizado, privatizado e refilantropizado, como bem atestou o Programa Comunidade Solidária e seus desdobramentos. (Yasbek, 2004:105)

O PETI - Programa de Erradicação do Trabalho Infantil foi a primeira experiência em escala nacional de TDCRs na América Latina. (Soares, 2011) O programa foi criado com o objetivo de enfrentar o trabalho infantil, então largamente difundida no Brasil e parte da cultura laboral e exploratória do país. Como afirma Monte:

As origens do trabalho infantil no Brasil remontam ao per' 1odo colonial e a implantação do regime escravagista, tendo sua estrutura mantida praticamente intacta durante todo o processo inicial de industrialização no País, obrigando o ingresso de grandes contingentes de crianças no sistema produtivo ao longo do século XX. No entanto, ao contrário do período industrial, as crianças do nosso tempo emancipam suas idades atrás de pequenos serviços, inclusive domésticos, e tentam, nas ruas e avenidas das grandes cidades, vender os mais variados produtos artesanais e industriais, para contribuir com a renda familiar e a sua própria subsistência (Monte, 2008:325)

A estratégia consistia em fornecer condições econômicas para que as famílias pudessem se livrar da dependência do trabalho infantil. À época, o programa transferia aos beneficiários 25 reais por criança abaixo de 14 anos. Como condicionalidade para o recebimento deste valor todas as crianças deveriam manter frequência escolar superior a $75 \%$.

Ao mesmo tempo, foram implementados programas locais de TDCRs nas cidades de Brasília e Campinas. O principal objetivo de ambos era o de estimular a frequência de filhos das famílias em condição de pobreza. O Bolsa Escola exigia como contrapartida o comparecimento a, no mínimo, $75 \%$ das aulas de todos os filhos das famílias beneficiárias.

O Bolsa Escola se difundiu rapidamente por outras capitais e, em 2001, foi alçado a condição de política nacional. Entre os objetivos elencados no projeto do programa, foi citado primeira vez de maneira explicita, a quebra do ciclo geracional de pobreza.

Nos anos que se seguiram, o país assistiu a uma explosão de programas inspirados principalmente no programa de Brasília. Nos anos 1997 e 1998, Belém, Belo Horizonte, Boa Vista, Catanduva, Ferraz de Vasconcelos, Franca, Guaratinguetá, Guariba, Goiânia, Jaboticabal, Jundiaí, Mundo Novo, Limeira, Osasco, Ourinhos, Paracatu, Piracicaba, Presidente Prudente, Santo André, São Francisco do Conde, São José do Conde, São José dos Campos, 
São Luís, Tocantins e Vitória (LAVINAS, 1998) criaram algum tipo de PTRC. (Ipea, 2010:30)

O Bolsa Escola nacional foi incorporado a recém criada Comunidade Ativa (substituta do Comunidade Solidária no segundo mandato de FHC), guarda-chuva institucional já se abrigavam o PETI e mais dois programas de TDCR voltados a segurança alimentar: o Bolsa Alimentação ${ }^{18}$ e o Programa Cartão Alimentação ${ }^{19}$.

Apesar dos programas contemporâneos de TDCR possuírem estruturas mais complexas, as características básicas já estão presentes nestas experiências originais: focalização, transferência direta de renda e a exigência de condicionalidades.

No entanto, o governo de FHC não pode ser visto como uma estrutura monolítica. Neste período, foi implementado também o Benefício de Prestação Continuada - BPC. Trata-se de um programa de transferência de renda incluído na legislação brasileira como um direito a todos os idosos e deficientes em condição de pobreza. Como afirmam, Azevedo e Burlandy:

$\mathrm{Na}$ esfera dos direitos assistenciais, o Benefício de Prestação Continuada (BPC) é o principal benefício implementado. Este prevê a transferência de um salário mínimo para idosos e deficientes que possuem uma renda familiar per capita inferior a $1 / 4$ do salário mínimo, sendo revisado a cada dois anos. (Azevedo e Burlandy, 2010:205)

O sistema de multiplos programas de TDCRs agregados de maneira a constituir uma rede de segurança social se mostrou pouco eficiente. Como já afirmava a época Amélia Cohn, este confuso conjunto de políticas regionais (bolsa Escola), municipais (políticas de Renda Mínima e Bolsa Escola Municipais) e federais (políticas incluídas no comunidade solidária) marca o governo FHC até o seu final.

Programa Comunidade Solidária, que vem enfrentando sérios problemas na sua efetivação, derivados não só das restrições

\footnotetext{
${ }^{18} \mathrm{O}$ programa previa a transferência de 15 reais por criança de famílias com renda abaixo da linha de pobreza nacional exclusivamente para a compra de alimentos. Em contrapartida eram exigidos o comparecimento as consultas de pré-natal - no casos de gravidez na família beneficiária - e a subsequente amamentação dos recém nascidos por um período mínimo de 6 meses. Além disso, as crianças da família deveriam manter vacinação atualizada de acordo com as normas do Ministério da Saúde.

19 Trata-se de um programa de transferência incondicional de renda no qual o governo federal fornecia um cartão que deveria ser utilizado para a compra de alimentos com o limite mensal de 15 reais por família.
} 
orçamentárias e da falta de agilidade dos aparatos institucionais governamentais, mas sobretudo da falta de definição clara e precisa do papel que cabe ao nível central e do lugar que o próprio programa ocupa no conjunto das políticas sociais do atual governo. (Cohn, 1995:16)

Os problemas não estavam limitados ao campo teórico e se estendem ao plano da gestão pública. A redundância, a ausência de sistema eficiente de dados e distribuição de benefícios e, principalmente, a incapacidade de monitorar o cumprimento das condicionalidades são algumas das criticas mais recorrentes a esta experiência.

A elevação da pobreza a uma posição central no discurso do Estado brasileiro e a consequente formulação de política pública voltada especificamente a este problema só vai ocorrer com chegada ao poder do Partido dos Trabalhadores em 2003, ano em que Lula ganha as eleições presidenciais.

A plataforma histórica do PT prometia um retorno as políticas de direito universal. E, de início, esse parecia ser o caminho que a ser adotado pelo governo Lula que anuncia em seu primeiro mês a implementação do programa Fome Zero, então carro chefe das ações sociais do governo.

Tratava-se de um plano que previa a implementação de mecanismos amplos de garantia da segurança alimentar, subsídios, interferências no sistema produtivo e combate a pobreza. Segundo os autores, de forma geral as ações do FZ foram desenhadas com o intuito de garantir o Direito Fundamental à Vida, para o qual a segurança alimentar é pré-condição. (Silva et All, 2010)

Ainda de acordo com a perspectiva dos formuladores do $\mathrm{FZ}$, a fome não poderia ser tratada por meio de uma política focalizada por ser fenômeno estrutural ao modelo econômico brasileiro. Diante deste diagnóstico, era preciso então constituir no país um conjunto amplo de ações para contrabalancear as tendências concentradoras e desiguais do modo de acumulação capitalista.

Instituído pela Medida Provisória no 132, de 20 de outubro de 2003, posteriormente convertida na Lei no 10.836, de 9 de janeiro de 2004, o Bolsa Família unificou os seguintes programas de transferência de renda do Governo Federal: Bolsa-Escola, AuxílioGás, Bolsa-Alimentação e Cartão-Alimentação5. No intuito de simplificar e agilizar a execução do projeto maior Fome Zero, o Bolsa Família passa a representar, em um só programa, os quatro anteriormente mencionados. (Rodrigues, 2008:37) 
Menos de um ano após o início do governo do Partido dos Trabalhadores, uma mudança radical na agenda social do governo se opera e PFZ é substituído pelo Programa Bolsa Família - PBF. Como consequência, a pobreza passa ser foco central das atenções e, no discurso do governo, a fome passa a ser vista como decorrente da pobreza.

O PBF agregou todos os programas e recursos das políticas anteriores em torno de apenas uma política de TDCR. Isso simplificou e barateou a gestão dos programas federais de proteção social e se tornou o maior programa de transferência de renda do mundo. (Banco Mundial, 2013).

O quadro abaixo sintetiza as transformações deste período até o PBF: 
Tabela 2 - Caminho ao Bolsa Família

\begin{tabular}{|c|c|}
\hline Ano & Legislação/programa \\
\hline 1995 & $\begin{array}{l}\text { Experiências pioneiras de Campinas e do Distrito Federal, com transferência de recursos a famílias que } \\
\text { garantissem a frequência escolar de suas crianças; }\end{array}$ \\
\hline 1996 & Programa Bolsa Escola de Belo Horizonte; \\
\hline 1996 & $\begin{array}{l}\text { Programa de Erradicação do Trabalho Infantil - sob responsabilidade do Governo Federal, implantado em } \\
\text { regiões com maior concentração de trabalho infantil degradante; }\end{array}$ \\
\hline 1998 & Programa Nacional de Garantia de Renda Mínima - sob responsabilidade do Ministério da Educação - MEC; \\
\hline 2001 & Programa Bolsa Escola (BES), vinculado ao Ministério de Educação; \\
\hline 2001 & Programa Bolsa Alimentação (BAL), vinculado ao Ministério da Saúde; \\
\hline 2002 & $\begin{array}{l}\text { Programa Auxílio Gás, gerido pelo Ministério de Minas e Energia. O Auxílio Gás não era um programa de } \\
\text { transferência condicionada, mas um benefício financeiro às famílias com renda familiar per capita mensal até } \\
1 / 2 \text { salário mínimo, como forma de compensar o aumento do preço do gás de cozinha, resultante da retirada do } \\
\text { subsídio naquele momento; }\end{array}$ \\
\hline 2003 & $\begin{array}{l}\text { Programa Cartão Alimentação, como um componente da estratégia denominada "Fome Zero". O Cartão } \\
\text { Alimentação era gerido pelo hoje extinto Ministério Extraordinário da Segurança Alimentar - MESA; }\end{array}$ \\
\hline 2003 & Criação, por Medida Provisória n 132, de 2003, do Programa Bolsa Família - PBF; \\
\hline 2004 & Promulgação da Lei da Renda Básica de Cidadania - Lei n 10.835 , de 2004; \\
\hline 2004 & Conversão em lei da Medida Provisória que criou o PBF. Lei n 10.836, de 2004. \\
\hline
\end{tabular}




\section{O Bolsa Família}

O PBF foi criado no final de 2003, a partir da fusão de quatro programas de transferência de renda preexistentes, sendo fortemente inspirada pelo programa de renda mínima vinculado à educação, o Bolsa Escola. (Ipea, 2012:35)

O Programa Bolsa Família se estabeleceu como a principal bandeira social do governo do partido dos trabalhadores durante a presidência de Lula (2003-2010) e manteve-se no mesmo condição para sua sucessora Dilma Rousseff, também do PT.

Os objetivos almejados pelo PBF são: reduzir a pobreza e
desigualdade de renda, provendo um benefício mínimo para
famílias pobres; reduzir a transmissão intergeracional de pobreza,
condicionando o recebimento dos benefícios a investimentos em
capital humano pelos beneficiários. (Ipea, 2012:35)

Em seu modelo atual, o PBF, tem foco nas famílias brasileiras cuja renda percapta se encontra abaixo dos 70 reais mensais. $\mathrm{O}$ benefício está condicionado a frequência escolar mínima de $75 \%$ para os filhos menores de 15 anos. Além disso, todos os membros da família devem comparecer a exames médicos preventivos, as mulheres grávidas devem fazer exames pré-natais mensais e os filhos devem ter a vacinação em dia com as normas nacionais de saúde.

Além dessa unificação de programas, o Bolsa Família integrou às ações do programa estados e municípios, criou uma rede de centros de atendimento para os beneficiários pelo país - os CRAS, implementou o banco de dados central do programa - o CadÚnico, e aumentou sistematicamente a quantidade de recursos alocados para ele (Ipea, 2010).

A importância relegada ao programa pode ser evidenciada pela rápida expansão do mesmo. A tabela abaixo mostra a evolução tanto do investimento quanto de famílias beneficiárias: 


\begin{tabular}{|l|c|c|}
\hline \multicolumn{1}{|c|}{ Ano } & Famílias (milhões) & Investimento (Bilhões de Reais) \\
\hline 2003 & 3.6 & 32 \\
\hline 2004 & 6.6 & 55 \\
\hline 2005 & 8.7 & 68 \\
\hline 2006 & 11.1 & 90 \\
\hline 2007 & 11.1 & 106 \\
\hline 2008 & 11.1 & 106 \\
\hline 2009 & 12.4 & 125 \\
\hline 2010 & 12.9 & 144 \\
\hline 2011 & 13.4 & 174 \\
\hline 2012 & 13.7 & 202 \\
\hline
\end{tabular}

Fonte: Ministério do Desenvolvimento Social e Combate à Fome

A implementação desta política, no entanto, não se encontrava prevista em nenhum plano de governo do partido e nem se alinha com as propostas históricas do PT de implementação de um programa de renda mínima, advogada pelo senador paulista Eduardo Suplicy, e de uma ação para a segurança alimentar, advogada por José Graziano.

O Bolsa Família representa, em última instância, um câmbio de posição do governo em direção a um modelo de Política Pública alinhada com a perspectiva das redes de segurança e ações focalizadas defendidas tanto pelas agências multilaterais de desenvolvimento.

Não é objeto desta tese julgar se foi ou não uma mudança acertada, mas evidenciar o fluxo hegemônico do desenvolvimento e suas consequências para o Estado Nacional brasileiro.

No entanto, a implementação e centralidade que o Bolsa Família assume, em substituição ao Programa Fome Zero, constitui terreno fértil ao objetivos desta tese. Isso, por dois motivos: a) se trata de um governo, a princípio, não alinhado com as visões do Banco, b) $\mathrm{O}$ 
combate a pobreza previsto nos planos originais do governo, em muitos aspectos, era contrário ao pensamento defendido pelo BIRD.

Em 2003, logo após a posse de Lula, as políticas sociais do governo foram centralizadas no Ministério Extraordinário de Segurança Alimentar e Combate a Fome (MESA) entregue a José Graziano da Silva um dos fundadores do Partido dos Trabalhadores. O professor e pesquisador da Universidade de Campinas, hoje presidente da FAO, e autor junto com Walter Belik e Maya Takagi, do projeto original do programa Fome Zero lançado em 2001 no Instituto Cidadania, fundado pelo próprio Lula.

Tratava-se de uma vitória dos setores mais progressistas do espectro político brasileiro. Desde a redemocratização estes grupos se encontravam na oposição aos governos conservadores anteriores a eleição de Lula e pregavam uma ação ampla contra a fome e pobreza.

O tema do combate a pobreza não estava ausente do programa FZ mas, era visto como condição derivada do problema da fome. Nas palavras de Maya Takagi que foi Secretária Executiva do MESA:

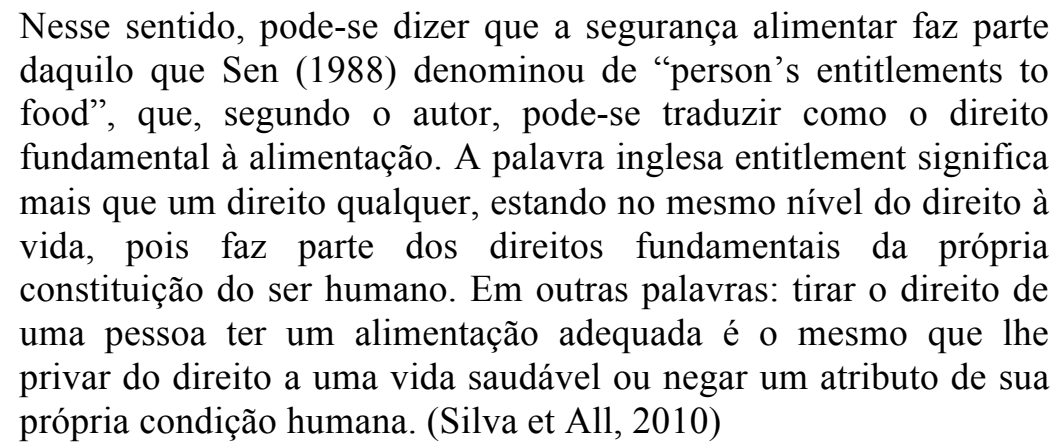

No plano original do Fome Zero, eram propostos três níveis de intervenção: Estruturais, Específicas e Locais. O plano era audacioso e amplo, somente entre as políticas específicas e locais somam mais de 20 diferentes ações (Silva et All, 2010).

A relação entre o emergencial e o permanente presente em todo o texto do documento, em diferentes perspectivas temporais com propostas de curto, médio e longo prazos, é sem dúvida um dos aspectos mais relevantes do projeto. (Yazbek, 2004:108)

Em paralelo a implementação do Fome Zero, trava-se nos corredores do governo Lula, um embate sobre os caminhos de combate a pobreza no Brasil. O próprio Graziano descreve o conflito: 
Um divisor de águas ficou bastante claro. Por um lado, há uma visão que defende que hoje há recursos e políticas suficientes e o problema é "focalizar melhor os pobres". Para seus defensores, os recursos dos programas sociais não chegam aos realmente necessitados de forma eficiente. Daí decorre a substituição de diversas políticas (como aquelas ligadas à distribuição de alimentos, por exemplo, o fornecimento de leite e cestas básicas) por uma complementação de renda. Esta é a proposta subjacente às políticas do atual governo, defendida por pesquisadores ligados ao Ipea e ao Banco Mundial.

A diferença com a proposta apresentada pelo Fome Zero é completa, como já tivemos oportunidade de destacar. Deste lado estão as propostas de políticas específicas de ajuda alimentar associadas a políticas estruturais como de geração de renda e emprego, reforma agrária, políticas de apoio à agricultura familiar, aumento do salário mínimo e ampliação da previdência social, por exemplo. Para seus defensores, políticas diretas de segurança alimentar e combate à fome devem ser adotadas de forma que estas forneçam os meios básicos para a sobrevivência das famílias sem condições econômicas, mas, ao mesmo tempo, criem mecanismos dinâmicos em outras áreas da economia, como a produção e a distribuição de alimentos, servindo, também, como mecanismos educativos para libertação da dependência destas políticas específicas. (Silva et All, 2010)

O trecho evidencia duas posições ideológicas. Por um Lado, encontra-se o Ipea e o Banco Mundial - defensores da focalização, centralidade do combate a pobreza e das transferências condicionais de renda. Por outro, o grupo de Graziano, então em comando do MESA que atribuíam centralidade a Segurança Alimentar a ser combatida sob uma perspectiva ampla de direitos.

As TDCRs não foram completamente ignoradas pelo FZ. No entanto, estavam relegadas a condição de ferramenta específica entre as ações propostas no plano. O trecho abaixo, contido no projeto original da do fome Zero, a transferência condicional de renda aparece como um dos subitens do Programa Cartão Alimentação - PCA:

São quatro as características básicas do PCA aqui proposto:

a) complementar a renda das famílias muito pobres até a li- nha de pobreza, independentemente de já se beneficiarem de ou- tros programas, como o Renda Mínima, Bolsa Escola, Previdência Social, Seguro-Desemprego etc.;

b) exigir sempre uma contrapartida específica das famílias que se beneficiam do programa em termos de ocupação de seus membros adultos, como, por exemplo, frequentar cursos de alfabe- tização, requalificação profissional ou até mesmo prestação de ser- viços 
comunitários compatíveis com suas habilidades profissionais, e ter acompanhamento por parte de equipes de saúde etc.; (Silva et All, 2010)

Ao final do ano de 2003, com a implementação do Fome Zero em pleno andamento, o governo realiza uma mudança profunda. Os rumos da política social passam a correr em sentido contrário as aspirações do grupo de José Graziano.

A criação do Bolsa Família promove o retomo das TDCRs como principal estratégia de política pública e promove o combate a pobreza a posição central na metas do desenvolvimento social brasileiro. De imediato incorpora os programas de segurança alimentar às transferência de renda, subordinando em termos conceituais, a fome à pobreza. O MESA é extinto e em seu lugar é criado o Ministério do Desenvolvimento Social e Combate a Fome - MDS.

O discurso do governo Lula abandona o viés dos direitos amplos e adota a focalização. Esta alteração, é uma evidência do caráter hegemonizante da difusão do projeto do desenvolvimento.

Para se diferenciar dos governos anteriores, no discurso oficial o PBF é definido como política de priorização. Esta termo procura situá-lo em posição intermediária entre os direitos universais e a focalização radicalizada. De acordo com Rosani Cunha, secretária executiva do MDS sintetiza esse pensamento:

Considerando as escolhas possíveis entre políticas de renda básica universal e políticas de transferência extremamente focalizadas, na concepção do Bolsa Família a redução da pobreza e da desigualdade pressupõem uma opção do Poder Público em privilegiar os mais pobres, mas construindo uma terceira concepção. O tratamento diferenciado dos mais pobres, de forma a reduzir desigualdades prévias, tem como pressuposto a promoção da igualdade. Encontra-se aqui uma tradução do princípio da equidade, que demanda, para sua efetivação, a utilização de parâmetros de justiça distributiva. Embora defenda políticas universais, entende-se que, mesmo essas, que são direitos de todos, devem ter um olhar diferenciado para os mais pobres, com priorização e garantia de atendimento. Para privilegiar os mais pobres, esta concepção também enfatiza critérios de acesso e, assim, trabalha com mecanismos de focalização, mas não numa concepção residual, de selecionar apenas os extremamente pobres. Focalização, aqui, é a aplicação de critérios de priorização, em especial para enfatizar a garantia de direitos e a inclusão daqueles que historicamente estiveram à margem das políticas públicas. (Cunha, S/D) 
De fato, o grau de focalização do PBF é menor do que os programas de transferências anteriores. Se o Bolsa Escola e o PETI estavam restritos a famílias com filhos em idade escolar o PBF só se atém a renda familiar como critério de inclusão.

No entanto, não se trata aqui somente de medir a amplitude da focalização, mas notar a mudança de perspectiva ideológica no combate a pobreza. Em última de adequação ao discurso neoliberal propagado pelas agências multilaterais de desenvolvimento.

O PBF não é um direito. Ao contrário, se encontra explicitamente condicionado às possibilidades orçamentárias. A lei que cria o PBF declara que: "O Poder Executivo deverá compatibilizar a quantidade de beneficiários do Programa Bolsa Família com as dotações orçamentárias existentes" (Lei no 10.836, de 9 de Janeiro de 2004, artigo 6, parágrafo único). (Ipea, 2009:32)

As críticas expressas pelo antigo grupo vinculado ao Fome Zero, centram-se no processo de focalização e na adoção das linhas de pobreza. Mayara Takagi, por exemplo, em texto posterior a implementação do Bolsa Família, apresenta a seguinte crítica:

Há uma segunda razão pela qual uma Política de Segurança Alimentar - e, em particular, uma política de combate à fome não deva ser diluída numa política geral de combate à pobreza. É a de que, embora as relações entre fome e pobreza constituam um círculo vicioso, a fome está na raiz da pobreza, sendo uma de suas causas mais importantes. (Silva et All, 2010)

A dificuldade principal de associar um programa de renda mínima com o direito é o caráter subjetivo do corte da renda: por que uma família que tem renda per capita abaixo de $\mathrm{R} \$ 100,00$ tem direito e aquela que ganha $\mathrm{R} \$ 100,50$ não tem? Como atualizar a linha de pobreza ao longo do tempo? Com qual critério? Qual o critério de saída das famílias do programa, se a família continuar em situação de vulnerabilidade social mesmo que aumente um pouco sua renda? (Silva et All, 2010)

Como percebemos nos trechos acima, ao focalizar políticas públicas pelo critério de linhas de pobreza, além de reduzir a renda um fenômeno multidimensional, riscos de injustiça nos casos limítrofes se tornam eminentes.

O estudo feito por Cotta e Machado (2013) sobre os efeitos das TDCRs na promoção da segurança alimentar e nutricional, reforça esta crítica. A conclusão da investigação identifica o aumento do acesso a alimentos, mas não a garantia a qualidade dos mesmos:

Os achados do presente artigo revelam um paradoxo referente ao impacto do PBF na segurança alimentar e nutricional dos 
beneficiários: o PBF promove um aumento do acesso aos alimentos que não é necessariamente acompanhado por um aumento da qualidade nutricional da alimentação. (Cotta e Machado, 2013:58)

A medição de problemas complexos como a pobreza por meio de um critério linear, submete os demais aspectos relevantes a esta condição. A fome não se resume a falta de alimento e inclui o acesso a dieta balanceada e em acordo com os padrões de saúde pública. Da mesma forma a pobreza é muito mais do que apenas a baixa renda familiar.

Uma das características da abordagem ao desenvolvimento social por meio das TDCRs é a adoção das linhas de pobreza. Se trata de indicador adotado pelo Banco Mundial a partir da década de 1990 e que descreveremos detalhadamente no capítulo seguinte.

O governo Lula não se mostrou absolutamente insensível a esta argumentação. Devido a flutuação da renda das famílias, o programa institui um período de dois anos em que a mesma pode permanecer como beneficiária, mesmo que a renda supere a linha de pobreza. Como afirma Soares

Given the long-term goals of the programme and the volatility of families' cash income, two important measures have been recently taken. The first is to establish a minimum period of two years during which an eligible family, which is non-compliant because of fluctuations in household income, can remain in the programme without the risk of being cancelled. (Soares, 2011:58)

A passagem da Segurança Alimentar à pobreza, simplifica a determinação do público beneficiário, por meio da adoção do critério exclusivo da renda familiar. Este critério linear de pobreza - em sintonia com a visão dos agentes multilaterais do desenvolvimento - apresenta vantagens operacionais e conduz a diminuição de gastos e a eficiência administrativa. A mudança é percebida por Rosani Cunha como aperfeiçoamento nos critério de definição de público alvo ou focalização:

A criação do Bolsa Família, no entanto, não pode ser entendida como uma mera unificação dos programas anteriores ou apenas a busca de um maior grau de racionalidade administrativa pelo governo. As características do PBF, detalhadas a seguir, mostram isto. Em especial, houve mudança de concepção no que diz respeito ao atendimento de toda a família, e não de seus membros isoladamente, à superação de divergências de critérios de elegibilidade e de sobreposição de público-alvo, à ampliação de cobertura e de recursos financeiros alocados, dentre outros. (Cunha, S/D) 
Mais do que uma justificativa técnica, o discurso sustentado pelo MDS, defende o critério da linha de pobreza como um "proxy" eficiente que incorpora os diversos níveis do fenômeno multidimensional da pobreza. Discurso, e termos, idênticos aos que constam nos documentos oficiais do Banco Mundial. Como afirmamos em outra parte desta tese, o discurso propagado no fluxo hegemonizante do desenvolvimento é incorporado pelos agentes periféricos, ou seja, se faz hegemônico.

A partir daí, os programas de transferência de renda ganharam
visibilidade como alternativa de política que articula diversas
dimensões econômicas e sociais e, ao mesmo tempo, incorporam
tanto visão de longo prazo, com impacto para gerações futuras,
como iniciativas de repercussão mais imediata nos indicadores de
pobreza e desigualdade. reconhecendo que pobreza é um
fenômeno multidimensional, que não se restringe à privação de
renda, vários estudiosos entendem que a insuficiência de renda é
uma boa representação, uma proxy, de outras dimensões de
pobreza. (Cunha, S/D)

Para além destas dimensões, outras mudanças entre os dois modelos podem ser ressaltadas. Primeiro, a quebra do ciclo da fome, como estava proposto pelo FZ, implicava ações voltadas tanto para a demanda de alimentos quanto para a estrutura produtiva. Isso significa incidir sobre as causas estruturais da fome.

Já o combate a pobreza, por meio das Transferências Condicionais de Renda, restringe-se a ações direcionadas aos beneficiários. Não procura atingir as estruturas econômicas excludentes do modo de produção capitalista.

Outra diferença central entre as duas propostas é o deslocamento do foco das transformações para o tempo futuro. A estratégia do Fome Zero visava acabar com o problema da fome sem distinção de geração.

O Bolsa Família posiciona o fim da pobreza nas expectativas de futuro. O ciclo da pobreza será interrompido pelo investimento nos mais jovens da família, enquanto, ações de alívio imediato lidam com a condição de vulnerabilidade atual.

A passagem do Fome Zero ao Bolsa Família, pelos motivos acima descritos, ilustram a transformação das políticas e discurso do Estado Nacional sobre a pobreza. Ocorre uma aproximação, se não um alinhamento, com a visão defendida pelas agências multilaterais de desenvolvimento e a incorporação do discurso ideológico neoliberal. Como já foi afirmado anteriormente trata-se de uma ação de mediação do Estado Brasileiro. 
As particularidades do modelo Latino Americano de TDCR, no qual o Bolsa Família se encaixa, não representa uma afastamento do fluxo hegemonizante do desenvolvimento, mas sua incorporação e instrumentalização a luz da realidade local.

\section{Do Progresa ao Oportunidades: breves notas sobre o caso mexicano.}

Este processo vivido no Brasil ocorre em paralelo a implementação no México do Programa de Educacion, Salud e Alimentacion (Progresa). Esta política de formato muito semelhante ao Bolsa Família acima descrito, foi iniciada no governo de Ernesto Zedillo Ponce de Leon (1994 - 2000) e restrito a zona rural.

In 1997, Mexico introduced the Programa de Educación, Salud, y Alimentación (PROGRESA) to support poor households with small children in the rural areas. In 2000, the program expanded to reach semi-urban beneficiaries as well as a few urban families. President Fox maintained PROGRESA during his first year in office and generally supported efforts to provide assistance to poor in marginalized regions (Dion, 2010: 205). In 2001, President Fox transformed PROGRESA into Oportunidades (Opportunities) and officially accelerated expansion of the program to include urban areas throughout the country. Oportunidades includes a cash transfer with three components: a household nutrition component, a school subsidy for each school-age child rising by grade (at the secondary school level there is a higher subsidy for girls) and an annual transfer to cover school costs (Barrientos and DeJong, 2006: 547). The conditionality component for the program is extensive and includes a school attendance record of at least 85 percent, parenting sessions, as well as health monitoring for mothers and infants. (Sugiyama, 2011:253)

Em 2001, o programa foi ampliado as zonas urbanas e renomeado Oportunidades e, dois anos depois, passa a ter abrangência nacional. Em 1997 o número de beneficiários era de 300.000 famílias e em 2009 alcança 2,5 milhões. (Soares, 2010)

Assim, em 1997, apenas um ano após a implantação do PETI e do Bolsa Escola no Brasil, o México inicia o primeiro programa Latino Americano de TDCR voltado especificamente ao combate a pobreza. As condicionalidades exigidas dos beneficiários estavam dividiam em três frentes: educação, saúde e segurança alimentar.

O programa mexicano Progresa/Oportunidades é um exemplo de

PTRC explicitamente desenhado para aumentar a transmissão 
intergeracional de capital humano. Não se fala em portas de saída, uma vez que é claro que as famílias devem receber o benefício por uma geração, até que as crianças de hoje sejam adultos de amanhã com alto capital humano, ou pelo menos com o mínimo garantido. (Soares, 2010:34)

A proximidade desta política pública com o Programa Bolsa Família é evidente. Esta semelhança, juntamente com o a incorporação do formato pelo Banco Mundial, fundamenta o que chamamos aqui de Modelo Latino Americano de TDCR.

\section{O modelo Latino Americano de Transferências Diretas Condicionais de Renda: resultados, debates e difusão.}

O Banco Mundial e os respectivos governos nacionais exaltam estes dois programas como casos de sucesso no combate a pobreza. Os dados socioeconômicos disponíveis sobre os dois países confirmam a redução da população de pobreza e extrema pobreza. No caso brasileiro, a queda mais intensa das taxas de pobreza ocorre em paralelo a implementação do PBF. Como mostra o gráfico abaixo:

Figura 5 - Evolução da taxa de pobreza no Brasil ${ }^{20}$

Families under higher poverty line of Millenium Goals (\%)

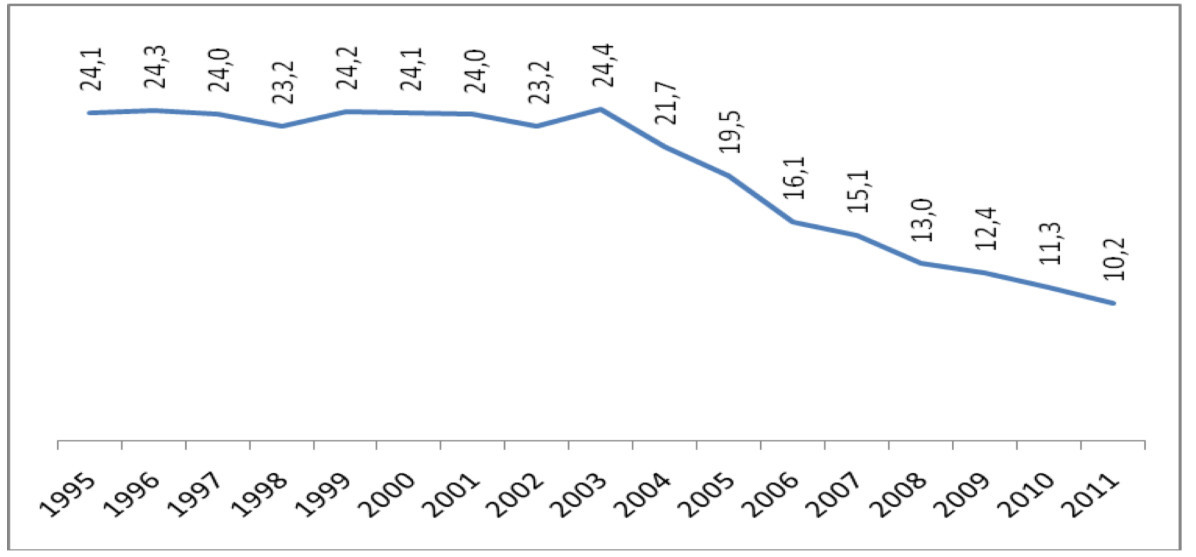

sorce: IPEA/ PNAD 1995-2011.

${ }^{20}$ Giugliano, R. (2013). Brazil and India CCT programs: a view of poverty and policy from the south. Presented in Santiago de Chile September 2013. 
Entre a implementação do PBF em 2003 e o ano de 2011, os que se encontravam abaixo da linha internacional de pobreza se reduz de $24 \%$ para $10 \%$ da população. Queda substancial para um período de apenas 8 anos.O mesmo pode ser observado em relação a extrema pobreza que, por quase uma década (1995 a 2003) se manteve entorno dos 17\%. Entre 2003 e 2009 a porcentagem da população brasileira em condição de miséria extrema cai para $8,4 \%$. Como podemos visualizar no gráfico abaixo produzido pelo IPC da ONU:

Figura 6 - Evolução da Taxa de Extrema Pobreza no Brasil ${ }^{21}$

Graph 1: Evolution of extreme poverty rate in Brazil: 1990 - 2009

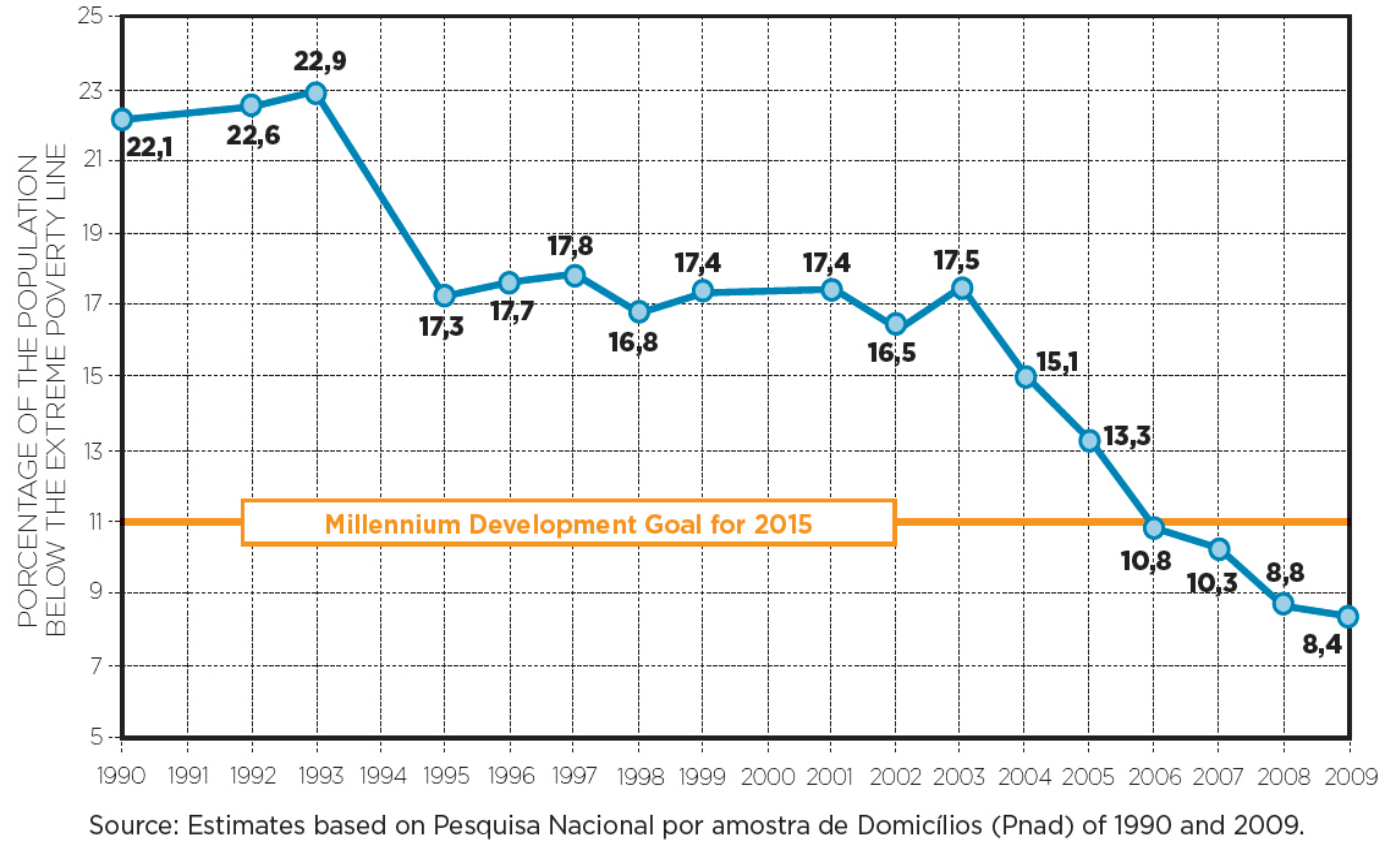

Os resultados do Progresa/Oportunidades também foram positivos, como denota o gráfico abaixo. O CONEVAL - Conselho Nacional de Avaliação da Política de Desenvolvimento Social - nota queda substancial nos níveis de pobreza no México desde a implementação o que só se reverterá com a crise econômica de 2007.

$21 \quad$ http://pressroom.ipc-undp.org/cash-transfers-combined-with-other-poverty-alleviation-programs-arecapable-of-increasing-the-productive-inclusion-of-poorer-brazilians/ Acessado em 23 de outubro de 2013 
Figura 7 - Evolução da taxa de pobreza no México $^{22}$

\section{BOIEVIaL}

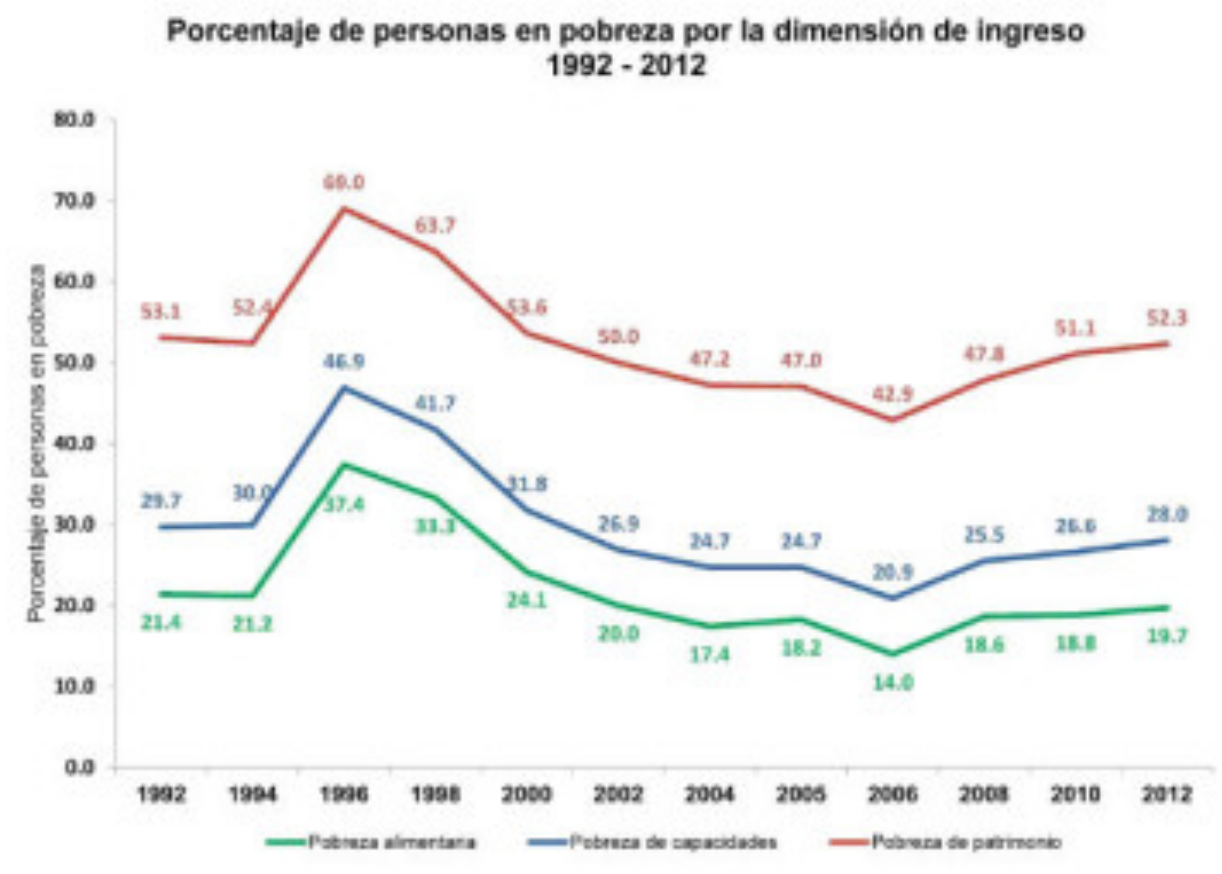

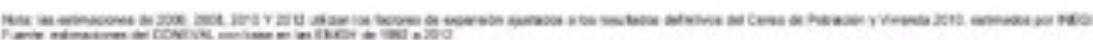

Estudo do Instituto de Pesquisas Econômicas Aplicadas - IPEA - realizado em 2012 demonstra estatisticamente que tanto o Bolsa Família, quanto o Oportunidades e programa Chile Solidário tiveram impacto direto na redução da taxa de pobreza e na queda do índice de gini nos três países. (Soares, 2007)

\footnotetext{
22 http://www.coneval.gob.mx/Medicion/Paginas/Evolucion-de-las-dimensiones-de-la-pobreza-1990-2010-
} .aspx acessado em 3 de novembro de 2014 
Estes dois programas definem o que chamamos aqui de modelo Latino Americano de TDCR para o combate a pobreza. Caracterizado por soares como: (De La O 2013; Ansell and Mitchell 2011; Driusso 2010).

CCT programmes in Latin America share some core characteristics such as the existence of targeting mechanisms; the notion of coresponsibilities, especially in health and education, to foster the accumulation of human capital by children; and the practice of payments being made in cash. These are apart from the two core objectives of poverty alleviation in the short-term and of breaking the intergenerational transmission of poverty in the long term. (Soares, 2011:55)

Em última análise, a particularidade deste modelo é o investimento em mudanças de hábitos dos beneficiários e a expectativa de efeitos benéficos de longo prazo que estas transformações podem gerar. Diversas experiências similares foram implementadas ao longo do mesmo período nos demais países da América Latina. (Cecchini e Madariaga, 2011)

Conditionalities aim to reinforce the human capital development impact of cash transfers, helping to break the inter-generational transmission of poverty by improving the child's likelihood of growing up and finding decent work. (Samson,2009:51)

Como afirma Samson as condicionalidades visam incentivar a quebra dos ciclos geracionais de pobreza. A imposição de frequência escolar mínima e de visitas regulares ao sistema de saúde aos beneficiários são considerados investimento em capital humano fundamentais ao desenvolvimento de capacidades necessárias para sair da condição de pobreza.

Os PTRC surgiram nos anos 1990 a partir de uma perspectiva de proteção social conhecida como paradigma de desenvolvimento humano (COTTA, 2009). Com base no trabalho de Amartya Sen (2000), tal paradigma coloca o indivíduo no centro do processo de desenvolvimento e sustenta que tal processo é desencadeado pelo concurso de diversos tipos de liberdades, que, por sua vez, dependem da aquisição de diversos tipos de capacidades. Para Sen (2000), o desenvolvimento é um processo de transformação econômica, política e social que faculta a cada pessoa a oportunidade de realizar seu potencial como ser humano. Contudo, para que isso ocorra, é preciso que as necessidades básicas individuais tenham sido atendidas. (SOARES, 2010:57) 
Como afirma Soares, a adoção de condicionalidades está associada ao pensamento de Amartya Sen sobre desenvolvimento social. Em termos gerais o pensamento do economista indiano, aponta para a privação de capacidades como causa da pobreza e o investimento no capital humano como condição necessária para a reversão desta situação. O trecho abaixo denota esta ideia:

\begin{abstract}
"A pobreza deve ser vista como privação das capacidades básicas em vez de meramente como baixo nível de renda, que é o critério tradicional de identificação da pobreza. A perspectiva da pobreza como privação de capacidades não envolve nenhuma negação da ideia sensata de que a renda baixa é claramente uma das causas principais da pobreza, pois a falta de renda pode ser uma razão primordial da privação de capacidades de uma pessoa." (SEN, 2010. p.120).
\end{abstract}

No entanto, por relacionar a pobreza a uma condição superável por investimentos nos próprios indivíduos destituídos, sua perspectiva foi intensamente criticada pelos setores mais progressistas do campo do desenvolvimento. Estes entendem que o autor relega a segundo plano a necessidade de transformação estruturais nas relações de produção, o que leva autores como Domingues, a posicionar o pensamento de Sen entre as fileiras do pensamento neoliberal:

\begin{abstract}
En primer lugar está la visión neoliberal de Sen (1999), que tuvo gran impacto, como una visión que superaría la concentración en los temas más estrictos de la economía, con el "desarrollo como libertad". Él se concentró en las libertades discretas del individuo, desechando la temática de la desigualdad interna de los países y entre ellos. se trata de hecho de una forma de neoliberalismo. Como todos los neoliberalismos, debe ser puesto en tela de juicio y rechazado. la concentración en el individuo, el pobre que necesita solamente poquitos recursos para vivir de manera decente oculta, de hecho, la jerarquización entre clases, géneros, razas, etnias, naciones y países en el seno de la modernidad, y en particular en lo que es tema funda-mental de este texto, del capitalismo (no obstante el liderazgo de Sen en la producción y difusión del índice de desarrollo Humano, IDH, que sirve para mensurar y tratar la situación más básica y general de las poblaciones, y en qué medida son atendidas por los Estados de los cuales son, en principio, ciudadanas). (Domingues, 2012: 57/58)
\end{abstract}

Esta tese não procura desvendar se de fato Sen se vincula formalmente ao neoliberalismo, até porque tal questão já se encontra exaustivamente debatida na literatura especializada. Nos basta aqui, identificar que seu pensamento foi utilizado por agências e governos no desenho das TDCRs. 
Conditional cash transfers (CCT) are defined as programmes that 'link safety nets directly to human capital development, by making receipt of the transfer conditional on school attendance and healthcare checkups' (Handa and Davis 2006: 513). Conditional cash transfers have come to dominate social protection programming in Latin America. Conditionality has perhaps been one of the most controversial aspects of the recent rise in adopting cash transfers as a means of poverty reduction. There are strong views on either side. (UNRISD, 2008:11)

A adoção de condicionalidades é, portanto, o aspecto mais inovador e controverso das políticas de transferência condicional de renda da América Latina. Entre os diversos debates suscitados, destacamos dois:

a) O primeiro, gira entorno do fato de que a exigência de condicionalidades pode deixar beneficiário incapazes de realizar tais contrapartidas excluídos das políticas de proteção social. Isso significa relegar indivíduos em casos de extrema pobreza a própria sorte.

b) A segunda discussão é o caráter civilizador que tais políticas apresentam. A adoção de condicionalidades são imposição sobre os hábitos e costumes das população vulneráveis.

No ano de 2011, segundo a Cepal, 18 programas desta natureza se encontravam em funcionamento (listados na tabela abaixo). Isso significa que entorno de 113 milhões de beneficiários, $20 \%$ da população da américa latina e tem custo estimado em $0,4 \%$ do PIB da região (Cecchini, 2011). 
Tabela 4 - Programas de Transferencia Direta de Renda na América Latina

\begin{tabular}{|l|l|}
\hline \multicolumn{1}{|c|}{ País } & \multicolumn{1}{c|}{ Nome e Ano de Início do Programa } \\
\hline Argentina & $\begin{array}{l}\text { Asignación Universal por Hijo para Protección Social (2009); } \\
\text { Programa Ciudadanía Porteña “Con todo derecho" (2005) }\end{array}$ \\
\hline Bolivia (Estado Plurinacional de) & $\begin{array}{l}\text { Bono Juancito Pinto (2006); } \\
\text { Bono Madre Niño-Niña “Juana Azurduy de Padilla" (2009) }\end{array}$ \\
\hline Brasil & Bolsa Família (2003) \\
\hline Chile & Chile Solidario (2002) \\
\hline Colombia & $\begin{array}{l}\text { Familias en Acción (2001); } \\
\text { Red Juntos (Red para la superación de la pobreza extrema) (2007); } \\
\text { Subsidios Condicionados a la Asistencia Escolar (2005) }\end{array}$ \\
\hline Costa Rica & Avancemos (2006) \\
\hline Ecuador & Bono de Desarrollo Humano (2003) \\
\hline El Salvador & Comunidades Solidarias Rurales (ex Red Solidaria) (2005) \\
\hline Guatemala & Mi Familia Progresa (2008) \\
\hline Honduras & $\begin{array}{l}\text { Programa de Asignación Familiar (PRAF) (1990); } \\
\text { Bono 10.000 Educación, Salud y Nutrición (2010) }\end{array}$ \\
\hline Jamaica & Programa de avance mediante la salud y la educación (PATH) (2002) \\
\hline México & Oportunidades (ex Progresa) (1997) \\
\hline
\end{tabular}

\section{Conclusão:}

Esta segunda parte foi dedicada a caracterização das políticas de Transferência Direta de Renda. O tema foi abordado por três vieses: a) A vinculação destas políticas ao uma concepção de pobreza ligada ao sul global, b) a tipificação das TDRs e c) o desenvolvimento do modelo latino-americano de Transferências Diretas Condicionais de Renda, com foco no caso do Bolsa Família. De forma sintética destacamos alguns dos pontos discutidos acima:

1. A diferença entre a percepção de pobreza no norte e sul global como um fator estruturante das estratégias adotadas pelos países para a formulação de suas políticas públicas. O quadro abaixo sistematiza este ponto: 
Tabela 5 - Pobreza e políticas públicas no norte e no sul global

\begin{tabular}{|l|l|l|l|}
\hline \multicolumn{1}{|c|}{$\begin{array}{c}\text { Espaço } \\
\text { econômico/epistêmico }\end{array}$} & \multicolumn{1}{|c|}{ Pobreza } & \multicolumn{1}{c|}{ Solução } & \multicolumn{1}{c|}{ Política Pública } \\
\hline Norte Global & $\begin{array}{l}\text { Decorrente do processo de } \\
\text { modernização }\end{array}$ & $\begin{array}{l}\text { Garantir o direito a } \\
\text { igualdade aos que são } \\
\text { afetados por esta condição. } \\
\text { Políticas amplas e } \\
\text { incondicionais. }\end{array}$ & $\begin{array}{l}\text { Garantias de } \\
\text { Mínima }\end{array}$ \\
\hline Sul Global & $\begin{array}{l}\text { Decorrente da falta de de } \\
\text { desenvolvimento }\end{array}$ & $\begin{array}{l}\text { Propiciar alívio a situações } \\
\text { emergenciais ao longo do } \\
\text { processo } \\
\text { desenvolvimento. } \\
\text { Políticas focalizadas }\end{array}$ & $\begin{array}{l}\text { Transferências diretas de } \\
\text { Renda }\end{array}$ \\
\hline
\end{tabular}

2. As TDRs podem ser tipificadas em dois modelos básicos: as transferências incondicionais e condicionais de renda. O quadro abaixo sintetiza o que foi acima descrito:

Tabela 6 - Tipologia das Transferências Diretas de Renda

\begin{tabular}{|c|c|c|c|}
\hline Modelo Geral & Características Gerais & Formatos específicos: & Características Específicas \\
\hline \multirow[t]{2}{*}{$\begin{array}{l}\text { Transferências } \\
\text { Diretas de Renda - } \\
\text { TDR }\end{array}$} & \multirow{2}{*}{$\begin{array}{l}\text { Modelo de política pública em que } \\
\text { recursos são enviado diretamente } \\
\text { aos beneficiários. } \\
\text { Passou a ser promovido na década } \\
\text { de } 1990 \text { pelo banco mundial a } \\
\text { partir do quadro social negativo } \\
\text { gerado pela implementação dos } \\
\text { ajustes estruturais no sul global. } \\
\text { Políticas não contributivas } \\
\text { Constituem parte do modelo de } \\
\text { proteção social baseado em redes } \\
\text { de segurança } \\
\text { Defendido pelo Banco Mundial a } \\
\text { partir das crises causadas pelos } \\
\text { ajustes estruturais } \\
\text { Não se constituem como direito } \\
\text { amplo e sim programa social } \\
\text { focalizado }\end{array}$} & $\begin{array}{l}\text { Transferências } \\
\text { Incondicionais de Renda }\end{array}$ & $\begin{array}{l}\text { Procuram promover o alívio de } \\
\text { situações emergenciais. } \\
\text { Poucos programas voltados } \\
\text { especificamente ao combate a } \\
\text { pobreza }\end{array}$ \\
\hline & & $\begin{array}{l}\text { Transferências } \\
\text { Condicionais de Renda }\end{array}$ & $\begin{array}{l}\text { Tem como objetivos: promover } \\
\text { alívio emergencial e investir no } \\
\text { capital humano das famílias } \\
\text { beneficiárias. } \\
\text { Embora tenha sido aplicado a } \\
\text { diversos problemas sociais, seu } \\
\text { uso mais recorrente é no } \\
\text { combate a pobreza } \\
\text { O modelo de TDCR } \\
\text { desenvolvido na América } \\
\text { Latina foi adotado pelo Banco } \\
\text { Mundial }\end{array}$ \\
\hline
\end{tabular}

3. O Modelo Latino-Americano de TDCRs representa uma evolução da estratégia tradicional de TDR, pois incorpora objetivos de longo prazo em que busca-se influenciar a vida dos beneficiários do programa de maneira a promover a quebra dos ciclos geracionais de pobreza. 
Trata-se de estratégia baseada no pensamento de Amartya Sen. O autor afirma que o baixo nível de capital humano das famílias pobres é tanto causa da condição de vulnerabilidade como empecilho para a superação da pobreza.

Para enfrentar essa situação os governos latino-americanos passaram a exigir contrapartidas ao beneficiários, especialmente educação e saúde, com o objetivo de promover capacidades aos membros mais jovens das famílias de baixa renda. $\mathrm{O}$ aumento do capital humano decorrente do cumprimento das condicionalidades visa dar base a uma quebra futura da condição de pobreza.

4. O caso do Programa Bolsa Família evidencia aspectos, tanto da vinculação ideológica das TDCRs quanto dos reflexos da implementação desta estratégia sobre os sistemas tradicionais de proteção social.

Ideologicamente, as TDCRs se vinculam ao modelo de proteção social promovido pelas agencias multilaterais de desenvolvimento desde a década de 1990. A adoção deste formato por estas instituição é resultante das crises sociais geradas pela implementação das políticas de ajuste estrutural ao dos anos 1980.

Os pontos abaixo sintetizam as principais características do processo de desenvolvimento e implementação do Bolsa Família no Brasil:

a) Centralidade da temática da pobreza sobre os demais temas sociais

b) A medição da pobreza pelo critério das linhas de renda

c) Programas focalizados em detrimento da constituição de direitos sociais amplos.

d) Busca combater a pobreza sem alterar sistemas produtivos 


\section{Capítulo 4 - Desenvolvimento, pobreza e o Banco Mundial.}

\section{Apresentação}

Este capítulo é dedicado ao Banco Mundial e seu papel no desenvolvimento e difusão das transferências diretas de renda como modelo de combate a pobreza. Os seguintes objetivos orientaram a composição deste capítulo:

a) Apresentar um pequeno histórico da instituição com ênfase na relação que o Banco estabelece com o tema da pobreza.

b) Identificar os principais documentos do Banco Mundial que evidenciam a adoção do modelo de proteção social por meio de redes de segurança.

c) Evidenciar a centralidade das TDRs como política modelo de combate a pobreza.

d) Apresentar evidências de como o Banco Mundial atuou na difusão TDCRs, e as dimensões desta disseminação na atualidade.

O Sistema Banco Mundial é atualmente formado por cinco instituições: a) O Banco Internacional de Reconstrução e Desenvolvimento - BIRD, b) Associação Internacional de Desenvolvimento - AID, c) Corporação Internacional de Investimento - CID, d) Centro Internacional para Arbitragem de Disputas sobre Investimentos - CIADI e a Agencia Multilateral de Garantia de Investimento - AMGI.

Para fins desta pesquisa nos limitaremos somente à análise do BIRD e da AID, uma vez que estas concentram as ações voltadas ao desenvolvimento da instituição. Daqui por diante, o termo Banco Mundial e a sigla BM refletirão apenas estas duas partes do sistema. 
A estrutura de poder, tanto no BIRD quanto na AID, se fundamenta nos recursos destinados por cada nação à instituição. Ou seja, a porcentagem de votos de cada membro na instituição são determinados pelo volume de participação dos países nos fundos do Banco. Os Estados Unidos da América é o maior doador de recursos para a instituição e consequentemente o mantém a parcela mais significativa do poder decisório. Atualmente, o país detém $15 \%$ dos votos no comitê executivo da instituição. Em conjunto, os países do norte capitalista, possuem um poder decisório de mais de $45 \%{ }^{23}$.

No entanto, estes percentuais refletem apenas o cenário contemporâneo da instituição que, desde a crise financeira de 2007/8, conta com uma participação cada vez maior da China e outros países do sul global. Ao longo da história do BIRD, o poder das nações centrais já foi ainda mais concentrado, especialmente em momentos de instabilidade econômica nos países em desenvolvimento. Este balanço de forças, fundamenta a escolha do Banco Mundial como representante institucional do projeto hegemônico de desenvolvimento assumida neste trabalho.

O Banco Mundial define sua atuação da seguinte maneira:

We provide low-interest loans, interest-free credits, and grants to developing countries. These support a wide array of investments in such areas as education, health, public administration, infrastructure, financial and private sector development, agriculture, and environmental and natural resource management. Some of our projects are cofinanced with governments, other multilateral institutions, commercial banks, export credit agencies, and private sector investors. (World Bank, 2014) ${ }^{24}$

Como denota a citação acima, o BM mundial procura fornecer empréstimos a juros baixos, créditos sem juros e doações exclusivamente voltadas a países em desenvolvimento. $\mathrm{O}$ critério usado pelo banco para definir tal condição é a Renda Nacional Bruta percapta $(\mathrm{RNBp})^{25}$ de cada país. A adoção de um indicador percapta tem a intensão de compensar a

\footnotetext{
${ }^{23}$ Dados de acordo com a divisão atual eleita em 2014. A mesma concentração de poder pode ser notada na AID, onde os Estados Unidos da América detém cerca de $11 \%$ dos voto o que configura o maior poder individual de voto na instituição. O quadro completo de cotas no conselho deliberativo tanto do BIRD quanto da IDA constam do anexo 1 e 2 desta tese.

${ }^{24}$ http://www.worldbank.org/en/about/what-we-do acessado no dia 20 de Janeiro de 2014

${ }^{25}$ For operational and analytical purposes, the World Bank's main criterion for classifying economies is gross national income (GNI) per capita. In previous editions of our publications, this term was referred to as gross national product, or GNP. Based on its GNI per capita, every economy is classified as low income, middle
} 
diferença populacional. O quadro abaixo sintetiza as categorias estabelecidas pela instituição:

Tabela 7 - Categorias de desenvolvimento segundo o Banco Mundial

\begin{tabular}{|l|l|l|l|}
\hline \multicolumn{5}{|c|}{ As nações aptas a requerer recursos do Banco Mundial voltados ao desenvolvimento } \\
\hline \multicolumn{1}{|c|}{ Categoria } & \multicolumn{1}{|c|}{ Critério } & \multicolumn{1}{c|}{ BIRD } & \multicolumn{1}{c|}{ AID } \\
\hline baixa renda & RNBp inferior a 1035 dólares & Não & Sim \\
\hline média baixa & RNBp entre 1036 e 4086 dólares & Sim & Sim \\
\hline média alta & RNBp entre 4086 e 12615 & Sim & Não \\
\hline alta & RNBp acima de 12.616 dólares & Não & Não \\
\hline
\end{tabular}

Este sistema classificatório evidencia alguns dos fundamentos utilizados pela instituição em sua cartografia do desenvolvimento:

a) O desenvolvimento é característica que se atribui as nações. Estes recortes políticos-territoriais são tratadas como totalidades mensuráveis e comparáveis. A diversidade deste territórios, bem como as desigualdades internas, se dissolvem diante da centralidade deste indicador econômico.

b) Como veremos adiante no capítulo dedicado a teoria do desenvolvimento, autores como Florestan Fernandes (1978), definem este fenômeno como uma forma de criar paralelos entre países sob o modelo civilizacional.

c) O desenvolvimento, como veremos no próximo tópico, se expande cada vez mais sobre o domínio do social. No entanto, o núcleo deste conceito ainda é econômico, cuja referencia principal é o modelo de acumulação capitalista.

d) A pretensão de universalidade que o projeto hegemônico de desenvolvimento atribui ao progresso. Todos os territórios são participantes de um processo amplo e comum a humanidade. O desenvolvimento como um caminho linear de transformação expõe a centralidade da categoria tempo no discurso do Banco Mundial pelo qual a diversidade é percebida como incompletude e atraso.

income (subdivided into lower middle and upper middle), or high income. Other analytical groups based on geographic regions are also used. 
Bhambhra (2010) afirma que o discurso do desenvolvimento promove uma quebra espacial no sistema mundo atual. O mapa abaixo ilustra esta fronteira entre $o$ desenvolvimento e sub-desenvolvimento de acordo com a visão do Banco Mundial. 


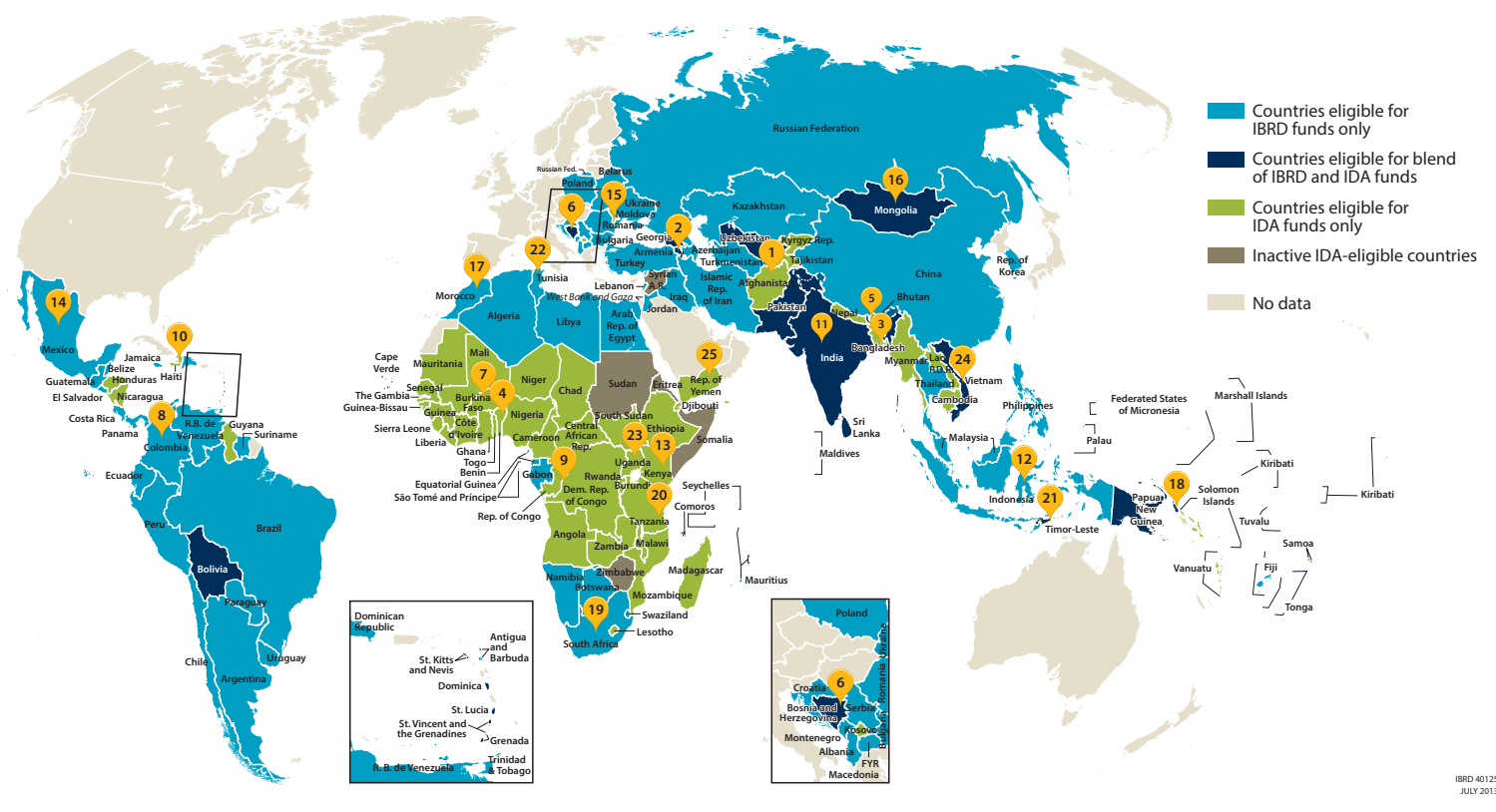

Os recursos captados pelo Banco Mundial, de acordo com a própria instituição, são destinados a promoção de dois objetivos:

a) Acabar com a extrema pobreza no mundo diminuído a porcentagem de pessoas vivendo com menos de $\$ 1,25$ para não mais do que 3\% do total da população e cada nação em desenvolvimento.

b) Promover a prosperidade coletiva pelo incentivo do crescimento da renda dos $40 \%$ mais pobres de cada nação. ${ }^{27}$

Este direcionamento também evidencia aspectos relevantes da cartografia do desenvolvimento adotada pela instituição:

a) a posição central que o combate a pobreza assume na agenda da instituição. No próximo seguimento, detalharemos o caminho que levou à adoção desta perspectiva de desenvolvimento.

\footnotetext{
${ }^{26}$ www.worldbank.com

${ }^{27}$ http://www.worldbank.org/en/about/what-we-do. Acessado no dia 20 de Janeiro de 2014.
} 
b) A pobreza é uma condição determinada exclusivamente pela renda e mensurada por um linha arbitrária e universal. Fatores como segurança alimentar, acesso a serviços públicos e bem estar são secundários a este indicador.

No ano de 2013 foram assinados entre os países em desenvolvimento e o sistema Banco Mundial acordos que somam US\$ 52,6 bilhões. Deste total, o BIRD foi responsável por US\$ 15,2 bilhões e o IDA por US\$ 16,3 bilhões. Estas duas instituições alocaram aproximadamente $60 \%$ do volume total empenhado pelo por todo o sistema Banco Mundial, ou seja: US\$ 31,5 bilhões (World Bank, 2013). Esses recursos foram distribuídos entre os continentes da seguinte maneira:

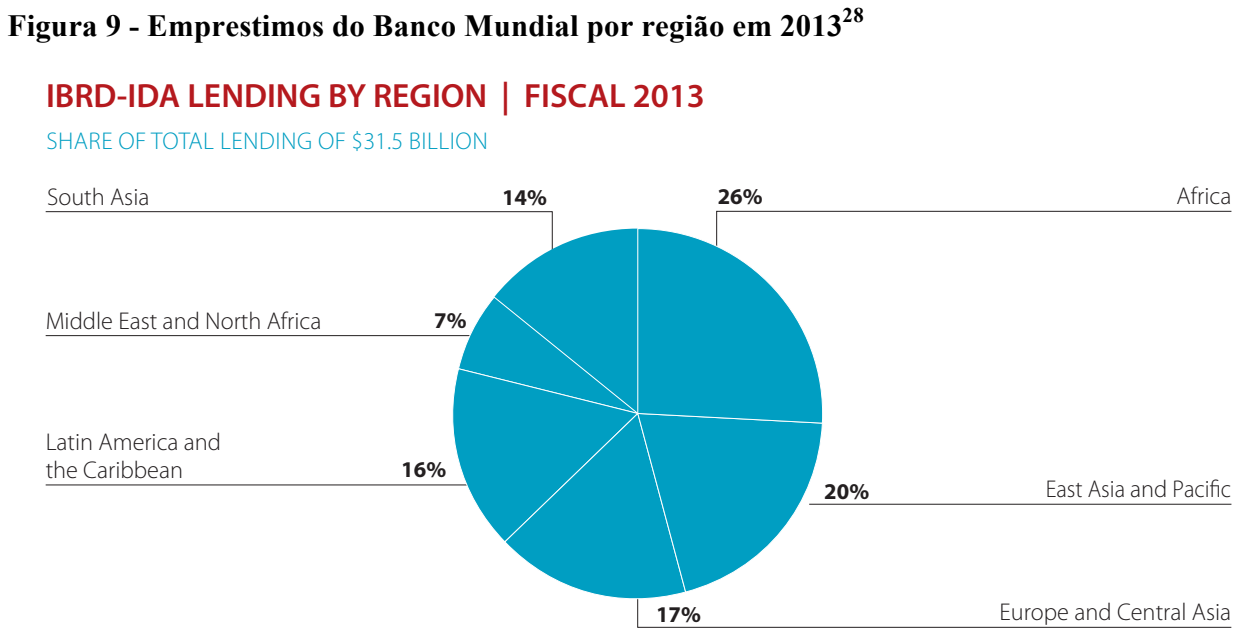

O empréstimos e financiamentos realizados pelo Banco Mundial no ano fiscal de 2013 foram divididos da seguinte maneira:

Figura 10 - Emprestimos do Banco Mundial por tema em $2013^{29}$

\footnotetext{
${ }^{28}$ World Bank annual report, 2013

29 World Bank annual report 2013
} 


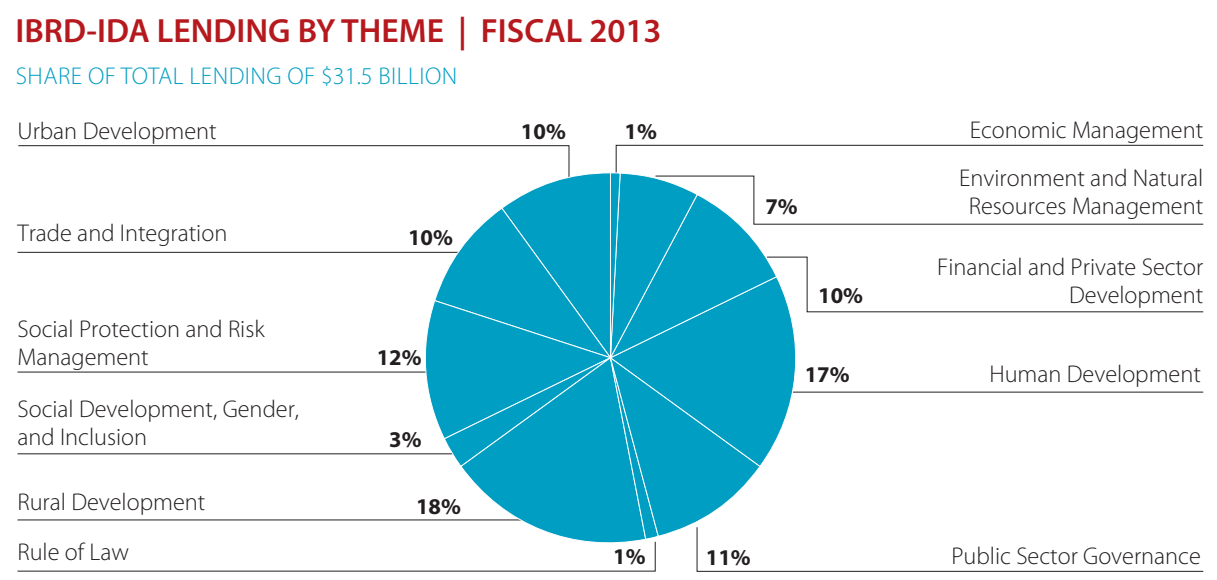

O gráfico acima mostra que os recursos voltados ao desenvolvimento foram destinados a temas que variam desde infraestrutura até a proteção social. As rubricas diretamente vinculadas a redução da pobreza - Social Protection e Risk Manegment, Human Development e Social Development e parte da Public Sector Governance - representam mais de $32 \%$ do volume total empenhado. Este montante representa o maior valor agregado entre todos os temas abordados pela instituição. Esta distribuição é outro indicativo da relevância que as questões sociais ocupam hoje no banco.

Este capítulo, além desta apresentação, é composto por três tópicos:

a) Breve histórico do Banco Mundial com foco na crescente importância das temáticas sociais, em especial da pobreza.

b) A descrição da participação da instituição na adoção do modelo de proteção social baseado em redes de segurança pelos países em desenvolvimento e centralidade das transferências diretas condicionais de renda.

c) Conclusão na qual são sintetizadas os aspectos mais relevantes a esta pesquisa levatadas ao longo da pesquisa sobre o Banco Munco Mundial 


\section{O Banco Mundial Breton Woods: da Reconstrução ao desenvolvimento.}

O período pós segunda guerra mundial consolidou o poder global em torno dos vencedores do conflito e estabeleceu uma nova ordem que só foi alterada significativamente com a queda do socialismo soviético. Uma das consequências desta nova configuração é a constituição de um novo formato de imposição de valores e modelos societais ao sul global, ou seja, o início do que Gustavo Estava denomina Era do Desenvolvimento. (ESTEVA, 2010).

Neste período, se consolida o que chamamos aqui de projeto hegemônico de desenvolvimento que, de forma sintética, se trata do esforço coordenado por instituições dominadas pelos países do norte global para conduzir e influenciar transformações na periferia do capitalismo. Tal projeto se orienta de acordo com interesses e valores predominantes das nações capitalistas desenvolvidas e está baseado nas relações assimétricas estabelecidas entre estes países e o restante do mundo.

Como já discutimos no capítulo metodológico, tratar do projeto hegemônico de desenvolvimento tem a intenção de limitar o foco deste trabalho as transformações conduzidas pelos agentes institucionais vinculados ao norte capitalista e os estados nacionais do sul global que se encontram em contato com estas agencias.

O campo do desenvolvimento, no entanto, é bem mais amplo do que as fronteiras estabelecidas por este trabalho. Contempla também, por exemplo, as múltiplas perspectivas alternativas ou contra-hegemônicas de progresso e inclui actantes sociais diversos, tais como: movimentos sociais, grupos tradicionais ou religiosos.

As agencias financeiras internacionais, cujas primeiras foram criadas na conferência de Breton Woods, são os principais actantes do projeto hegemônico do desenvolvimento. Estas instituições atuam como mediadoras ${ }^{30}$ entre o norte desenvolvido e sul global e o Banco Mundial é a mais significativa entre elas.

\footnotetext{
${ }^{30} \mathrm{O}$ uso do termo mediador aqui esta em sintonia com sentido atribuído por Bruno Latour, o qual nos permite representar o Banco Mundial como mais do que um mero intermediário entre os interesses dos Estados Nacionais do norte capitalista e sul global. Ou seja, a instituição se configura como actante do campo do desenvolvimento e, portanto, gera efeitos próprios.
} 
Ao longo dos já quase 65 anos de existência do Banco Mundial, a definição de desenvolvimento foi continuamente redefinida e ampliada. Isto significa que o termo não pode ser abordado como um fenômeno estável. Pelo contrário, a ideia de desenvolvimento se adaptou constantemente aos interesses econômicos e políticos norte americanos moldados pelos ventos de um mundo em movimento.

Kapur, Lewis e Webb (1997), resumem as primeiras 5 décadas de existência Banco Mundial a um processo que o transformou de uma instituição financeira voltada a reconstrução à uma agência de desenvolvimento. Trata-se de uma mudança profunda de objetivos e resultado de uma história particular que descrevermos a seguir.

Ao longo deste processo ocorreram outras duas transformações relevantes a estas tese que merecem destaque. a) Primeiramente, neste período a instituição aperfeiçoou os mecanismos e a intensidade da influencia sobre as nações periféricas. Ou seja, de um início marcado por financiamentos pontuais de obras de infraestrutura e uma diretriz de não interferência nas questões internas dos países clientes, hoje o Banco demonstra interesse em múltiplos temas e procura atuar em todas as esferas internas dos países clientes.

Em segundo lugar, b) ampliou-se os temas que compõem a agenda de desenvolvimento da instituição. De uma definição inicial de desenvolvimento exclusivamente econômica, o Banco Mundial incorporou paulatinamente as temáticas sociais. O quadro abaixo sintetiza os processos e transformações que o Banco Mundial viveu, relevantes a esta tese e serão abaixo detalhadas, desde sua fundação até os dias atuais:

Figura 11 - Expansão da agenda do desenvolvimento do Banco Mundial

No entanto, não pretendemos com tal escolha diminuir o fato de que as nações do norte capitalista exercem hegemonia real sobre as instituições de Breton Woods e, portanto, essas tem sido veículos da narrativa oriunda dos espaços dominantes do atual sistema-mundo. 
Grande Influência sobre os países clientes

Definição econômica restrita de desenvolvimento
Definição Ampla de desenvolvimento que incluí temas sociais

\section{Ações Pontuais}

Ações Sistêmicas

Fundado em 1944 e inaugurado em 1946, o Banco Internacional de Reconstrução e Desenvolvimento (BIRD ou Banco Mundial) foi criado em Breton Woods com o objetivo de promover a reconstrução dos países atingidos pela guerra. Segundo o plano original, uma vez concluída esta tarefa, a instituição assumiria, ao lado do FMI, o papel de garantir a estabilidade dos sistemas financeiros e comerciais do mundo pós-conflito.

The Bank would provide capital for reconstruction and short-term capital to support international trade, and help create economic stability by redistributing gold, thus stabilizing prices, raising living standards worldwide, and reducing or eliminating financial crises and economic depressions. (Murphy, 2008:33)

$\mathrm{Na}$ visão dos participantes da concertação pós-guerra, as crises e instabilidades econômicas figuravam entre as principais causas do conflito. Assim, para evitar novas guerras, era necessário estabelecer um sistema financeiro internacional para prevenir a recorrência de tal cenário.

A fundação do Banco Mundial foi proposta do governo estadunidense. Harry Dexter White, diretor de pesquisa monetária dos EUA e principal conselheiro econômico do secretario do tesouro americano Henry Morganthau, foi responsável pelo desenho inicial do Banco apresentado na conferência. 
Em contraste, a delegação inglesa propôs a criação de um fundo monetário internacional para concentrar os recursos da reconstrução europeia e, posteriormente, garantir a estabilidade financeira internacional. O plano foi desenhado pelo então conselheiro do tesouro inglês, lorde John Maynard Keynes. (Kapur et Al, 1997)

Os dois principais arquitetos do BIRD e do FMI almejavam o comando de suas criações logo após a criação formal das instituições. No entanto, nenhum atingiu este objetivo, devido a morte de Keynes e a acusação de que White mantinha conexões comunistas.

Pela proposta de White, a reconstrução pós-guerra deveria ser realizada por instituição financeira de moldes tradicionais. Ou seja, o Banco Mundial captaria recursos tanto de estados nacionais quanto de investidores privados por meio da venda de títulos nos mercados de capitais. A proposta de Keynes, por outro lado, visava a criação de fundo composto exclusivamente por doações estatais. O acordo alcançado entre as duas potências em Breton Woods resultou na criação de ambas as instituições. Ainda hoje o FMI e BM figuram entre as maiores agencias financeiras multilaterais.

Se por um lado estas duas instituições representem o esforço conjunto dos aliados capitalistas para a reconstrução europeia, por outro, são indícios de uma divisão entre as estratégias estadunidense e inglesa. Até hoje, o FMI e sua sucessão de presidentes europeus e o Banco Mundial, sempre comandado por norte-americanos, continuam a expressar tal cisão.

O desenvolvimento não constava da proposta original do Banco Mundial. A inclusão deste objetivo foi resultado de pressão exercida pelos participantes latino-americanos durante a conferência de Breton Woods, em especial a Venezuela e o México. (Kapur, 1997)

Henry White era integrante dos setores mais progressistas do partido Democrata Americano, grupo ao qual o então presidente Franklin Delano Roosevelt também era vinculado. A estratégia defendida por eles visava a constituição de um sistema de concertação internacional, incluindo até uma aproximação com a URSS.

As late as May 1947, U.S. policymakers expected the IBRD and the IMF to provide resources for what became the Marshall Plan. In the middle of 1947, however, the United States abandoned hope of relying on these relatively limited international institutions. (Wood, 1986:22) 
No entanto, pouco tempo depois de sua criação, o Banco Mundial foi relegado a uma posição secundária na agenda norte americana de reconstrução pós-guerra. Este rebaixamento foi causado pela lentidão e complexidade enfrentadas para a constituição do BIRD. Um processo veloz era considerado estratégico e necessário pelo governo norteamericano como forma de frear o avanço do comunismo Soviético. (Wood, 1986) Diante disso, o Plano Marshall que se mostrou um mecanismo mais simples, eficiente e rápido e, portanto, se consolidou como principal caminho para destinar recursos a reconstrução europeia.

Este início claudicante e cheio de incertezas, gerou dificuldades até para nomear o primeiro presidente do Banco e levou a nomeação de um mandatário pouco expressivo tanto no cenário nacional norte-americano, quanto internacionalmente. Eugene Meyer, primeiro a assumir o posto mais alto na hierarquia do BIRD, era então um ex-banqueiro e ex-funcionário do governo norte-americano de 70 anos que na época ocupava a presidência do Washington Post. (Kapur, 1997)

Logo no início de sua gestão, Meyer se envolveu em grave divergência com o representante do seu próprio país no conselho gestor da instituição, Emilio Colado. Este último desejava concentrar as decisões estratégicas nas mãos do conselho e limitar a presidência somente a função executiva. Este embate resultou na queda do primeiro presidente do BIRD antes dos seis primeiros meses de seu mandato.

Até então o desenvolvimento, incluído de ultima hora à missão do banco, estava relegado a narrativa da instituição. Foi com a morte de Roosevelt e a eleição de Truman, um conservador, que este quadro começou a ser alterado.

Como afirma Wood (1986), logo no primeiro ano de mandato do novo presidente foram demitidos os nomes progressistas norte-americanos das instituições multilaterais, fato que marca o abandono completo do projeto inicial pensado por Henry White.

White's purging and that of countless other progressives in all the post-War transnational institutions marked a fundamental retreat away from the truly global economic and political system they had struggled to create. (Murphy, 2008:41)

Como afirma Murphy, Estas mudanças compõem um redirecionamento mais amplo da política internacional dos EUA que ocorria naquele momento, no qual o país se afasta da crença em um sistema verdadeiramente multilateral e se volta a um anticomunismo 
extremo. Neste contexto, o desenvolvimento das ex-colônias europeias se eleva a condição de componente estratégico.

O desenvolvimento, apenas um adendo ao plano inicial do Banco Mundial, principia então um caminho que moldará os objetivos centrais da instituição na atualidade e a elevou a condição de actante central do campo hegemônico do desenvolvimento. $\mathrm{O}$ discurso inaugural de Truman, momento referencial deste cenário de mudanças, é apontado por Esteva como o marco inicial da era do desenvolvimento. (Esteva, 2010)

No trecho abaixo, retirado do discurso de Truman, o então presidente explicita a importância do desenvolvimento para a nova política internacional do país:

Fourth, we must embark on a bold new program for making the benefits of our scientific advances and industrial progress available for the improvement and growth of underdeveloped areas. 44

More than half the people of the world are living in conditions approaching misery. Their food is inadequate. They are victims of disease. Their economic life is primitive and stagnant. Their poverty is a handicap and a threat both to them and to more prosperous areas. $\quad 45$

For the first time in history, humanity possesses the knowledge and the skill to relieve the suffering of these people.

46

The United States is pre-eminent among nations in the development of industrial and scientific techniques. The material resources which we can afford to use for the assistance of other peoples are limited. But our imponderable resources in technical knowledge are constantly growing and are inexhaustible. 47

I believe that we should make available to peace-loving peoples the benefits of our store of technical knowledge in order to help them realize their aspirations for a better life. And, in cooperation with other nations, we should foster capital investment in areas needing development. 48

Our aim should be to help the free peoples of the world, through their own efforts, to produce more food, more clothing, more materials for housing, and more mechanical power to lighten their burdens.

49

We invite other countries to pool their technological resources in this undertaking. Their contributions will be warmly welcomed. This should be a cooperative enterprise in which all nations work together through the United Nations and its specialized agencies wherever practicable. It must be a worldwide effort for the achievement of peace, plenty, and freedom. $\quad 50$ 
With the cooperation of business, private capital, agriculture, and labor in this country, this program can greatly increase the industrial activity in other nations and can raise substantially their standards of living. $\quad 51$

Such new economic developments must be devised and controlled to benefit the peoples of the areas in which they are established. Guarantees to the investor must be balanced by guarantees in the interest of the people whose resources and whose labour go into these developments. $\quad 52$

The old imperialism - exploitation for foreign profit - has no place in our plans. What we envisage is a program of development based on the concepts of democratic fair-dealing. ${ }^{31}$

Deste extrato já é possível destacar algumas características do projeto hegemônico do desenvolvimento:

a) A ascensão dos EUA como potência hegemônica e a decadência do modelo imperialista europeu.

b) A centralidade do combate ao comunismo como justificativa para investir nas excolônias para promover o modelo capitalista de acumulação.

c) O papel central atribuído às agencias internacionais de desenvolvimento..

d) O progresso tecnológico e o crescimento econômico são apresentados como caminho para a emancipação dos povos.

e) O desenvolvimento é apresentado como missão civilizadora do norte em direção ao sul global. O objetivo desta intervenção é promover o modelo societal norte americano nas ex-colônias, denominado por ele Democractic Fair-Dealing.

Os princípios apresentados no discurso de Truman confirmam - como já discutimos em capítulo anterior - que a pobreza no sul global está, aos olhos do norte, associada a falta de progresso. O desenvolvimento é apresentado como caminho para romper com esta condição de atraso tecnológico e científico e o papel civilizador de liderança que os Estados Unidos da América se propunham a realizar. O BIRD, agencia de desenvolvimento multilateral que se encontrava mais firmemente sob a hegemonia da nova potência mundial se tornaria uma das ferramentas institucionais voltadas a este fim.

Em termos práticos, a crescente importância que o desenvolvimento assume desde então para o Banco Mundial, exigiu uma definição de desenvolvimento que sobre a qual se

\footnotetext{
${ }^{31}$ http://www.loc.gov acessado em 08 de julho de 2013
} 
pudesse operacionalizar as ações da instituição. O pensamento do economista Arthur Lewis, um dos mais importantes de sua época e prêmio Nobel da economia de 1979, serviram como a primeira referencia teórica para tal fim. O desenvolvimento, pela ótica de Lewis, era meramente um sinônimo de crescimento econômico. (Esteva, 2010)

\begin{abstract}
Development, which had suffered the most dramatic and grotesque metamorphosis of its history in Truman's hands, was impoverished even more in the hands of its first promoters, who reduced it to economic growth. For these men, development consisted simply of growth in the income per person in economically underdeveloped areas. It was the goal proposed by Lewis in 1944 and insinuated by the United Nations Charter in 1947. (ESTEVA, 2010:8)
\end{abstract}

Com o objetivo de promover esta visão inicial de desenvolvimento o Banco passa a disponibilizar recursos para implementar ou aprimorar a infraestrutura da extração e exportação de matérias primas para as ex-colônias. (Kapur, 1997) A adoção desta estratégia expõem uma contradição entre os princípios de rompimento com modelo exploratório colonial e imperial expressos no discurso de Truman e as ações do BIRD.

O condição de subalternidade nos tempos coloniais relegava a economia dos territórios ultramarinos ao papel de prover matérias primas às suas metrópoles. Portanto, financiar infraestruturas de extração e exportação de bens primários faz dos primeiros investimentos em desenvolvimento uma forma de dar continuidade as relações assimétricas entre norte e sul.

Outro indicativo deste mesmo fenômeno, foi a destinação de recursos do BIRD para o desenvolvimento de territórios que ainda não haviam alcançado independência. Um exemplo, foi o empréstimo feito ao Congo Belga na década de 1950. O resultado desta situação foi a retenção de parte dos recursos pela Bélgica e o restante foi destinado de acordo com os interesses econômicos da própria metrópole. (Kapur, 1997) O investimento em infraestrutura estava portanto em sintonia, como demonstra esse caso, com os interesses econômicos metropolitanos.

Além disso, as diretrizes então adotadas pela instituição previam uma relação pouco intrusiva com os países clientes. Isto significa que neste período o BIRD procurava não se envolver em questões políticas internas das nações nem interferir nas estratégias amplas de crescimento adotadas pelos tomadores de empréstimos. O Banco se limitava a analisar e financiar projetos pontuais. 
A perspectiva de desenvolvimento adotada pelo Banco Mundial foi alvo de críticas desde seu início, mesmo entre intelectuais norte americanos. Já na década de 50, o sociólogo Robert Bellah da Universidade de Berkeley, defendia a adoção de uma perspectiva mais ampla de desenvolvimento. Como afirma Alejandro Portes (1997) sobre o trabalho de Bellah, era preciso ir além da economia e promover também valores, normas e instituições do ocidente.

\footnotetext{
"Development was a question of installing the 'right' orientations - values and norms - in the cultures of non-western world so as to enable its people to partake in the modern wealth-creating economic and political institutions of the advanced West.”(PORTES, 1997:230)
}

Apesar destas críticas, foi somente após 20 anos que o Banco Mundial começou a ampliar sua agenda de investimentos. A primeira etapa deste processo foi destinação de recursos a desconstrução das economias rurais (backwards) e a promoção de um modelo econômico baseado na industrialização. (Kapur, 1997)

Estende-se assim a concepção de desenvolvimento adotada pelo Banco Mundial em duas direções: a) por um lado a instituição passou, desde então, a destinar recursos para a promoção de mudanças estruturais nas economias do sul e, por outro, b) o Banco abandona sua política de ações pontuais e de caráter pouco intrusiva nos países clientes.

Esta mudança foi reflexo da crescente influência que as teorias da modernização passaram a exercer sobre a instituição desde o final da década de 1960. A teoria da modernização se constituiu, segundo Habermas, como a principal alternativa norte americana a ideia europeia de modernidade (Murphy, 2008).

Como descreve Gilman (2006), para Habermas estes pensadores sistematizaram a experiência histórica-societal de período específico continente europeu em fórmula universal e, portanto, destituída de espacialidade e temporalidade.

As Habermas would observe in the 1980s, the modernization theorists separated the concept of modernity from its origins as a description of a specific period of European history and "stylized it into a spatio-temporally neutral model for the process of social development in general. (Gilman, 2006:78)

Este modelo espaço-temporal neutro, expõem o caráter etnocêntrico do projeto hegemônico do desenvolvimento. Em última análise, a teoria da modernização apresenta 
um fundamento epistemológico importante da cartografia do desenvolvimento pela qual o progresso aparece como um processo temporal singular e universal.

No entanto, esta transferência entre o local e o universal, produz uma narrativa que silencia a importância da acumulação por destituição (Patnaik e Moyo, 2011) promovida pela exploração colonial para o desenvolvimento europeu, juntamente com a relevância da segunda guerra para a hegemonia econômica norte americana. Estes silêncios, em última análise, são evidência de que a cartografia hegemônica do desenvolvimento não confere importância as relações assimétricas entre os territórios do centro e da periferia do sistema mundo atual para o progresso do norte capitalista.

Modernization theorists like sociologists Edward Shils and Talcott Parsons, economist Walt Whitman Rostow, and political scientists Gabriel Almond and Lucian Pye conceived of modernity as a "syndrome" that included technological advancement, urbanization, rising income, increased literacy, and the amplification of mass media. (Gilman, 2003:5)

A modernidade, experiência espaço-temporal complexa e multivariada, foi transformada em um conjunto restrito de características ou objetivos. Esta "síndrome", como afirma Gilman (2003), também expõem características incorporadas a narrativa hegemônica do desenvolvimento. a) Primeiro, a imagem de destino/futuro promovida pelo agentes institucionais do desenvolvimento corresponde ao próprio modelo societal norte americano transformado em utopia. E, b) segundo, o progresso universal e linear pode ser traduzido operacionalmente em etapas pré-estabelecidas de avanço e transformação.

Walt Whitman Rostow, autor do livro As Etapas do Desenvolvimento, foi um dos expoentes da teoria da modernização. Economista, analista político e um anticomunista radical, serviu aos governos de Lyndon Johnson e John Kennedy e teve papel proeminente na elaboração e implementação do Plano Marshall.

Descreveremos a seguir, de maneira breve, a obra Rostow no intuito de exemplificar as ideias desta corrente. A escolha por autor se justifica, tanto pela grande influencia que suas ideias exerceram sobre o governo norte americano, quanto pela forma clara pela qual elas evidenciam os fundamentos ideológicos assumidos pelo projeto hegemônico do desenvolvimento a partir das décadas de 1960 e 1970.

Na década de 50, a teoria do desenvolvimento alcançou seu ponto mais radical e, ao mesmo tempo, mais divulgado na obra de W.W. 
Rostov (1961). Ele definiu todas as sociedades pré-capitalistas como tradicionais. Este barbarismo histórico, que provocou os protestos dos historiadores sérios, era necessário para ressaltar os vários estágios do desenvolvimento que se iniciaria com o famoso "take-off", a "decolagem" do desenvolvimento que teria ocorrido na Inglaterra de 1760, nos Estados Unidos pós-guerra civil, na Alemanha de Bismarck, no Japão da Restauração Meiji, etc. A questão do desenvolvimento passou a ser assim um modelo ideal de ações econômicas, sociais e políticas interligadas que ocorreriam em determinados países, sempre que se dessem as condições ideais à sua "decolagem". (Santos, SD:4)

Rostow (1978) descreve o desenvolvimento como um processo composto de cinco etapas partindo do que ele denomina sociedade tradicional. Este termo designa a organização produtiva baseada na agricultura de subsistência e extrativismo, comum a maioria dos países periféricos de então. Segundo o autor, este modelo econômico deveria ser completamente substituído para dar lugar a sociedade moderna emancipadora.

Para iniciar a jornada do desenvolvimento, segundo Rostow, seria necessário promover condições para o que ele chama de "decolagem". Em termos práticos isto significava acabar sistemas de produção baseadas na subsistência e a implementar uma produção agrícola capitalista. A consequência esperada era a constituição de um mercado interno e o crescimento do PIB pela exportação.

Uma vez estabelecidas estas condições, as nações estariam aptas a realizar a decolagem propriamente. A característica mais importante desta etapa é a promoção da industrialização das economias em desenvolvimento. A sintonia entre esta perspectiva e as novas diretrizes adotadas pelo Banco Mundial são evidentes.

A conclusão desta fase conduz as nações ao que Rostow denomina maturidade. A metáfora com o desenvolvimento humano reforça o caráter evolucionista desta narrativa teórica em que o sul é representado como espaços incompleto e atrasados no processo universal e linear do progresso. Neste período ocorria, na utopia da modernização, a consolidação das transformações modernas e a difusão dos benefícios do desenvolvimento por toda a sociedade.

A última etapa, decorrente da maturidade, seria a constituição de uma sociedade de consumo de massa, modelo mais avançado de desenvolvimento segundo o autor. A conclusão do trilha do progresso nada mais é do que uma imagem utópica do autor sobre o seu próprio país. O quadro abaixo sintetiza as etapas proposta pelo autor: 
Tabela 8 - As etapas do desenvolvimento segundo Rostow

\begin{tabular}{|l|l|}
\hline \multicolumn{2}{|c|}{ Etapas do desenvolvimento segundo W. W. Rostow } \\
\hline Ponto de partida & Sociedades atrasadas ou rurais \\
\hline $\begin{array}{l}\text { Condições para a } \\
\text { decolagem }\end{array}$ & $\begin{array}{l}\text { Quebra do sistema de produção rural, investimento em infraestrutura, introdução da produção } \\
\text { agrícola capitalista e constituição de mercados }\end{array}$ \\
\hline Decolagem & Industrialização \\
\hline Maturidade & Diversificação da base industrial e construção de infraestrutura social \\
\hline $\begin{array}{l}\text { Sociedade de consumo } \\
\text { de massa }\end{array}$ & $\begin{array}{l}\text { Resultado do processo de desenvolvimento e reprodução do modelo societal do norte } \\
\text { hegemônico. }\end{array}$ \\
\hline
\end{tabular}

Como afirma Kapur (1997), o Banco Mundial, agora sintonizado com perspectivas como a de Rostow, passa a enfrentar, em um mundo majoritariamente rural, o desafio de promover a industrialização. O objetivo da instituição ainda era promover o crescimento econômico das nações do sul global, mas o caminho para atingir tal meta mais complexo.

Nesta fase, o BIRD ainda não destinava empréstimos a questões sociais. Isso pois, como exemplificado na obra de Rostow, o bem estar da população ocorreria como consequência do processo de desenvolvimento econômico. Se difundiria pela sociedade em efeito "trickle down" - ainda hoje popular entre os setores mais conservadores do pensamento econômico - desde as elites até os grupos mais vulneráveis.

Em paralelo a crescente influencia da teoria da modernização sobre o Banco Mundial, o cenário internacional assistia naquele momento a intensificação da guerra fria. A crescente tensão entre EUA e URSS, fez com que o Banco Mundial passasse a exercer cada vez mais um papel central na agenda internacional dos governos norte americanos.

Segundo Murphy (2008), trata-se do período de maior politização da instituição. A instrumentalização do Banco para o combate ao comunismo alcançou tal importância que tornou insuficiente até a hegemonia exercida pelos EUA no conselho gestor. Era preciso agir mais como agencia de desenvolvimento e menos como banco para se contrapor as promessas de igualdade e bem estar das sociedades comunistas. 
Pelo desenho institucional do BIRD, o processo decisório demandava muitas concertações com os demais países e a submissão dos empréstimos a critérios bancários tradicionais e o pagamento de dividendos a investidores. Estas características limitavam um uso político mais intenso do Banco. Foi neste contexto histórico que se deu a criação da segunda instituição do sistema Banco Mundial voltada ao desenvolvimento, a International Development Association - fundada em 1961.

The IDA was an American administration idea, linked to its growing worry that Communists were on the verge of taking power in a number of developing countries, a concern that had deepened considerably after Castro's takeover of Cuba in 1959. (Murphy, 2008:46)

Os empréstimos do IDA não preveem a cobrança de juros e, portanto, não podem ser captados nos mercados de capitais. As nações que contribuem com recursos a esta agencia não o fazem por meio da compra de títulos, mas através de doações diretas. A principal fonte de recursos da nova instituição passou a ser o tesouro dos EUA, fato que permitiu ao congresso e o governo estadunidense impor um maior direcionamento político.

Segundo George e Sabelli (1994), mesmo diante deste ajuste de rumos, os primeiros 20 anos de história do Banco são marcados por timidez. Isso, tanto pelo volume de recursos investidos quanto em resultados práticos.

\footnotetext{
"Together, over twenty years, these gentleman lent a grand total of $\$ 10.7$ billion (not counting IDA credits which, from 1961 to 1967 , added a further $\$ 1.7$ billion to the portfolio). In only one year, 1965, did IBRD commitments top the billion dollar mark." (GEORGE e SABELLI, 1994:37)

“The Bank's presidents were bankers and businessmen doing business with sovereign governments - both borrowers and lenders. They and their bank had no particular interest in poverty, much less in the poor. (GEORGE e SABELLI, 1994:38)
}

Esta situação só começou a ser alterada com a chegada de Robert Mcnamara a presidência do Banco em 1968. Durante sua gestão nota-se um aumento significativo no volume de recursos emprestados, uma valorização estratégica ainda maior do Banco no combate ao comunismo e uma nova etapa de ampliação da agenda desenvolvimentista da instituição. Como podemos perceber na tabela 9, nos anos de 1960 são destinados mais recursos a empréstimos do que as duas décadas anteriores juntas. 
Macnamara assume a presidência do Banco por indicação de Lyndon Johnson, governo no qual Rostow ocupou posto no departamento de defesa. A conexão entre os dois vai além de uma passagem simultânea pelo governo norte-americano e representa o auge da hegemonia das Teorias da Modernização na instituição.

Foi também Macnamara o primeiro presidente a incorporar o combate a pobreza formalmente aos objetivos da instituição. A causa desta mudança foi fundamentada na crença do novo mandatário de que induzir melhoras nas condições de vida das populações das ex-colônias era uma das formas mais significativas para combater o avanço comunista. A tabela 9 indica que os primeiros investimentos sociais do BM ocorrem justamente na década em que MacNamara chega a presidência da instituição.

For McNamara, the Bank was a tool to defeat Communism by addressing the ills that gave rise to Communist sympathies: "unless there is visible progress toward a solution [of less developed country poverty] we shall not have a peaceful world. (Murphy, 2008:46)

Ainda segundo Macnamara, o fracasso das estratégias de desenvolvimento perseguidas até então pelo Banco não havia sido causada somente pelo volume limitado de recursos empregados. Sendo também impactadas negativamente pela ineficiência e a corrupção dos governos das nações periféricas que passariam desde então a compor a agenda de transformações direcionadas aos países do sul global.

O solução foi voltar as ações do Banco Mundial a liberalização das economias, como contraponto a ineficiência dos governos, e o aperfeiçoamento das estruturas de gestão do Estado. Como consequência, a definição de desenvolvimento se ampliou ainda mais para a instituição que passou a incorporar naquele momento novos elementos, tais como: a necessidade de gestão moderna e a abertura dos mercados das ex-colônias. A pobreza, embora somada as preocupações formais da instituição, recebeu uma fatia anda pouco relevante de recursos, como demonstra a tabela 09.

As mudanças impostas por Macnamara levaram o projeto do desenvolvimento a ter objetivos mais ambiciosos. No entanto, o poder de influência do Banco sobre os países em desenvolvimento permanecia muito limitado em comparação as pretensões da instituição.

McNamara retired in 1981, and most of his senior management team left with him. McNamara's replacement Tom Clausen selected Anne Krueger, a prominent neo-liberal ideologue, as chief 
economist. Krueger soon became the dominant force in the Bank. (Murphy, 2008:49)

Como afirma Murphy, a saída de McNamara, marca também o fim do domínio da teoria da modernização sobre a instituição e o início da hegemonia do pensamento neoliberal. Tal mudança ocorreu ao mesmo tempo em que a transformação do contexto econômico internacional permitiu um novo grau de influencia da instituição sobre os países clientes.

International development proved fertile ground for neo-liberals. Oil price shocks in the late 1970s forced many developing countries to appeal to donor countries and the international financial institutions for help, just when neo- liberal economists, particularly Milton Friedman, were attracting broad interest (Murshed, apud Murphy, 2008:49).

O contexto de falta de liquidez e alto endividamento das nações periféricas do final do anos 1970 e início da década de 1980, aumentaram a dependência deste países de empréstimos internacionais. Diante deste cenário o Banco Mundial passa a condicionar empréstimos a transformações nos países clientes, os chamados ajustes estruturais.

El Banco Mundial (BM) implementó en 1979 los préstamos de ajuste estructural como una medida transitoria destinada a los países en desarrollo que afrontaban problemas en su balanza de pagos o tenían un gran endeudamiento externo. (Spicker, P et al, 2009:41)

As condições de crise nos países periféricos fez com que os ajustes se difundissem pelo sul global de maneira muito intensa. Segundo Patnaik (2006), mais de 70 países de maneira completa ou parcial. Isso representa mais de um terço dos 188 países clientes do Banco. Constitui-se, portanto, um fluxo hegemonizante entre os atores do desenvolvimento. Isso pois, instabilidade financeira no sul aumentou tanto a dependência como o caráter assimétrico das relações entre norte sul e possibilitou uma disseminação intensa do modelo neoliberal de desenvolvimento.

O economista John Williamson (2001), criador do termo consenso de Washington que designa um conjunto de dez orientações que passaram então a ser exigidas aos países receptores de empréstimos. Estas eram:

1. Fiscal discipline.

2. A redirection of public expenditure priorities toward fields offering both high economic returns and the potential to 
improve income distribution, such as primary health care, primary education, and infrastructure.

3. Tax reform (to lower marginal rates and broaden the tax base).

4. Interest rate liberalization.

5. A competitive exchange rate.

6. Trade liberalization.

7. Liberalization of FDI inflows.

8. Privatization.

9. Deregulation (in the sense of abolishing barriers to entry and exit).

10. Secure property rights.

(Williamson, 2001. P:6)

O condicionamento de financiamentos a tais é evidência de mais uma ampliação da agenda do desenvolvimento para o Banco. Desde então, a instituição passou a impor políticas como privatizações/redução do Estado o que representa um aumento tanto de escopo quanto da profundidade da interferência que o Banco procurava gerar nos países do sul global. Em ultima análise trata-se da intensificação do caráter civilizador do projeto hegemônico do desenvolvimento e o auge da assimetria das relações entre centro e periferia.

A figura abaixo sintetiza a ampliação da agenda de interesses do BIRD/IDA ao longo de sua história, desde a fundação até a atualidade de acordo com Kapur 1997:

Figura 12 - Processo de ampliação da agenda desenvolvimentista do banco mundial 

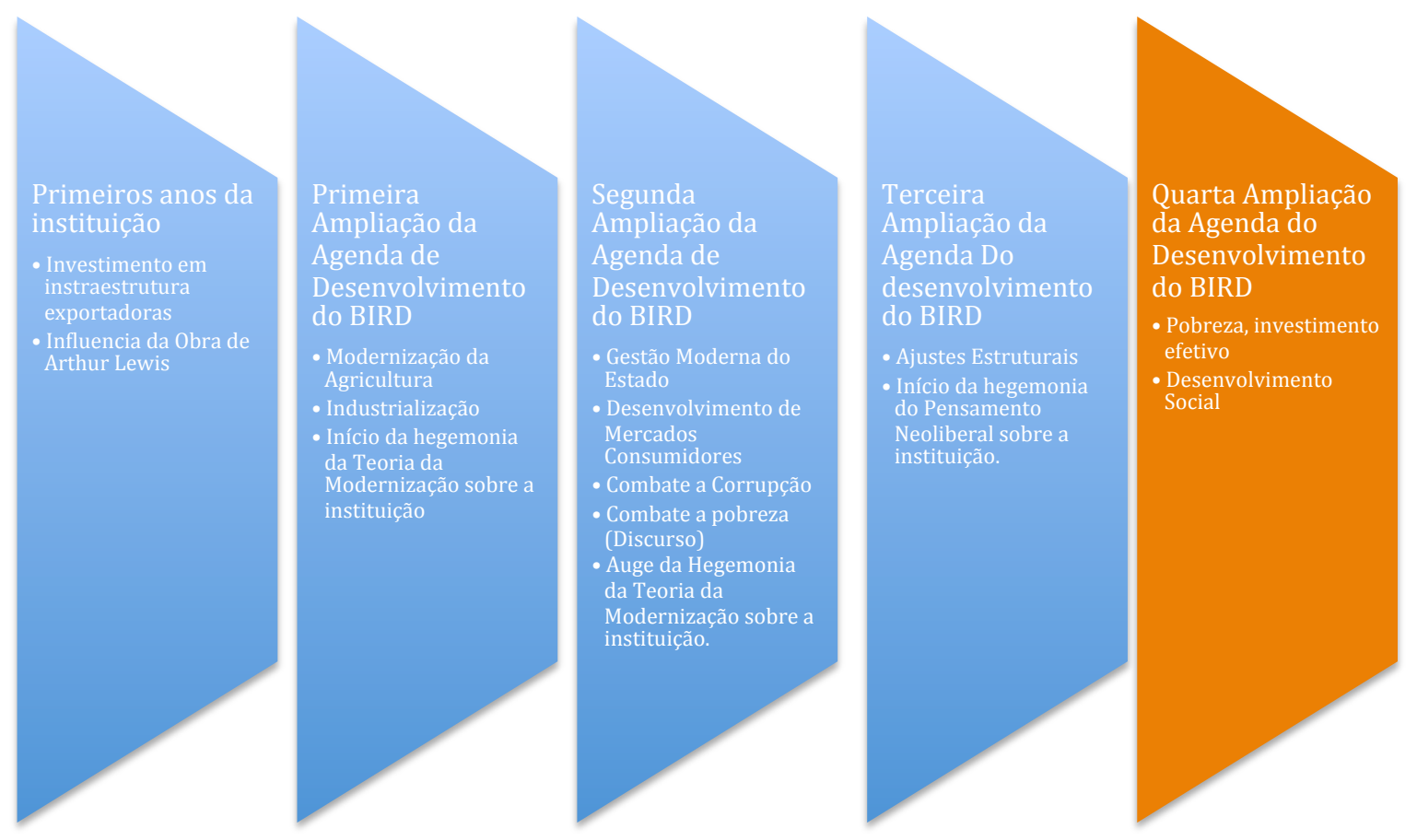

A intensidade da interferência do BIRD característica deste período, leva Gervais (1992), a

definir os ajustes estruturais como uma forma de neo-colonialismo. O autor argumenta, como denota o trecho abaixo, que o Banco Nesse momento se afasta de maneira definitiva de uma instituição bancária tradicional e :

The structural adjustment period set in motion a growing divergence between the Bank's activities and anything that could be viewed as traditional banking activity. The Bank had always had influence over government policy, proportional to the size of the projects it funded, the importance of projects to the overall national budget, and the fungibility of the project resources to be provided. Nevertheless, by and large, the scope for the Bank's policy intervention had remained morally and rationally circumscribed within the range of policy options having a direct bearing on the success of its specific projects.

In contrast, structural adjustment policy lending established a neocolonial relationship in which the local elite was required to carry out the policy edicts and adopt the philosophical standpoint of the international financial institution lender, now taking the colonists' place. While many critics have noted the questionable relationship of domination and subservience inherent in the policy lending framework, policy lending also corrodes developing country elites' leadership responsibility and undermines elite/citizenry interdependence in favour of a global elite/local elite relationship. The new breed of monetarist economists, who came to dominate the Bank during the structural adjustment period, were articulate and generally accurate raconteurs of the moral hazards inherent in state control of the economy. However, they were less prescient in 
identifying the moral hazards caused by forcing governments to adopt policies in which they did not genuinely believe (Gervais, 1992). (Murphy, 2008:50)

Assim como Murphy, Kapur também identifica este momento a compleição de um ciclo para o BM. Os ajustes estruturais configuram a ultima etapa da jornada que transformou uma instituição Bancária Internacional de reconstrução pós-guerra e promotora da estabilidade financeira em uma agência de Desenvolvimento.

No entanto, a difusão do modelo neoliberal criado para sanar um sistema econômico mundial em crise e impõem cortes orçamentários severos aos países clientes em nome deste fim causou, pelo contrário, mais instabilidade.

O quadro de crises econômicas gerou, por sua vez, um agravamento de problemas sociais, como aumento da desigualdade, da concentração de renda e da pobreza nos países que adotaram os ajustes estruturais. Foi este quadro, a principal causa que levou a instituição a retirar a pobreza e o desenvolvimento do status de discurso (Kapur, 1997) e a se constituir como diretriz de fato para os recursos da instituição ( Murphy, 2008).

The first twenty-six annual reports of the Bank barely touch on the subject of poverty, and the Bank's twenty-fifth anniversary history almost ignores the concept: its index lists "poverty" only three times (in each case, "rural poverty").5 That long silence on the subject is a startling contrast to the latter-day, ringing affirmations of social commitment and concern, such as the opening remarks of Armeane Choksi, Bank vice president, to a meeting at the United Nations in 1993: "Poverty reduction is now at the top of the World Bank's agenda." (Kapur, 2003:p132)

Como afirma Kupur, (2003) a palavra pobreza só começa a ser adicionada aos documentos do Banco Mundial após quase 30 anos de existência da instituição durante a gestão de McNamara. No entanto, ações diretas contra a pobreza são imperceptíveis na agenda de empréstimos do banco. $\mathrm{O}$ bem estar social ainda era visto como visto como consequência do crescimento e aprimoramento da economia.

Most recently, the global financial crisis that firsth it East Asia and then Russia and Brazilin 1997-1998 also helped establish social protection asone of the critical elements of a sustainable poverty reduction strategy. (World Bank, 2001:SP) 
Será apenas a partir dos primeiros sinais da derrota na guerra a pobreza que emergem com as crises econômicas do Brasil, Rússia e Argentina o tema se eleva na tanto no discurso como na agenda de empréstimos do Banco, Murphy chama este momento de "Poverty Turn”.

By 1992, the Bank's staff operational manual emphasised that poverty reduction was the benchmark for measuring success (Kapur et al., 1997a: 51). The rhetorical shift intensified with the arrival of the charismatic Clinton nominee James Wolfensohn as Bank president in 1995, and Joseph Stiglitz's appointment as chief economist in 1997. By 1999, when the Bank adopted PRSP methodology, all the Bank's activities were to be tied to the ultimate objective of reducing poverty. (Murphy, 2008:53)

O fracasso social do radicalismo de mercado, levou o Banco Mundial a se reposicionar também quanto ao papel do Estado, mudança que ocorreu oficialmente no ano de 1997 e marca o arrefecimento do fundamentalismo de mercado na instituição. (Tarassiouk, 2007) O Estado, até então visto apenas como um problema pelos neoliberais, passa a ser aceito novamente como ator chave para o desenvolvimento no sul.

A ação social que foi proposta pelo Banco aos países clientes era a criação políticas públicas de caráter focalizado que estabelecessem redes de segurança nacionais voltadas para populações vulneráveis, em momentos de crise. Uma das principais entre estratégias propostas pelo Banco estão as Transferências Diretas de Incondicionais de Renda Descritas no capítulo 2.

Portanto, este momento em que se nota um recuo por parte do Banco em relação ao fundamentalismo de mercado, esta resposta se dá pela forma de uma nova ampliação da agenda do hegemônico do desenvolvimento. Nesta ultima etapa de expansão do escopo deste projeto o Banco se volta em direção as temáticas sociais, até então relegadas apenas ao discurso do BIRD. No entanto, como argumenta Murphy, não ocorre um arrefecimento da intrusividade da instituição nos países do sul, mas, pelo contrário, uma maior interferência do que no princípio dos ajustes estruturais.:

Far from representing merely a sprinkling of angel dust on the heavy pudding of structural adjustment, the "poverty turn" reflects a more intrusive managerialist orientation than structural adjustment. (Murphy, 2088:53) 
Com a chamada poverty turn da década de 1990, a pobreza é alçada a condição de tema prioritário aos olhos do banco sobressaindo-se aos demais campos do desenvolvimento social. Com isso tornou-se necessário uma definição operacional para esta condição social. Este fenômeno, naquele momento já exaustivamente abordado pela teoria social como de caráter múltiplo e diverso, será reduzido a um indicador unidimensional restrito a renda de famílias e indivíduos em condição de vulnerabilidade.

Em documento oficial do ano de 1995 conselho de desenvolvimento - comitê conjunto do Banco Mundial e do Fundo Monetário Internacional, aponta para a reunião de Bangkok, realizada em 1991 como momento em que a o Pobreza se torna o principal objetivo das ações da Instituição. (World Bank, 2011)

As chamadas linhas de pobreza são, ao mesmo tempo um critério objetivo e de operacionalização simples para o designe de políticas públicas e, um forma de reduzir as diferenças entre as diversas pobrezas e riquezas no sul global. Trata-se de mais uma evidência do caráter universalizante do projeto do desenvolvimento.

A utilização deste critério é justificado pelo fato do BIRD impor que as políticas sociais não tivessem caráter de direito amplo e sim de ações limitadas as populações mais afetadas. Com isso, a instituição mantém sua distância do modelo do bem estar e das políticas de garantias mínimas de renda características do combate a pobreza nos países do norte global, como apresentamos no capítulo 2.

A diferença entre o modelos de combate a pobreza imposto pelo Banco aos seus clientes e o que é adotado nos países capitalistas hegemônicos na própria instituição é mais uma evidência da quebra espacial inscrita na narrativa do desenvolvimento. A fronteia entre centro e periferia não define apenas diferentes níveis de produção e acumulo de riqueza, mas também determinam a percepção dos fenômenos sociais e a forma como estes devem ser tratados.

O Banco adota a sua primeira linha global de pobreza em 1991 com base no estudo encomendado aos economistas Ravaillion, Datt e Van de Walle. A pesquisa utilizou de dados compilados de linhas de pobreza nacionais de 33 países pobres. O resultado apresentado indicava que pessosas vivendo com menos US\$1 ao dia (referenciado no poder de consumo do ano de 1985) eram tipicamente pobres nos países em desenvolvimento. 
Ravallion, Datt and van de Walle (RDV) (1991), in research for the 1990 World Development Report (World Bank, 1990), compiled data on national poverty lines across 33 countries and proposed a poverty line of $\$ 1$ per day at 1985 Purchasing Power Parity (PPP) as being typical of low-income countries. ${ }^{2}$ They estimated that one third of the population of the developing world in 1985 lived below this line. ${ }^{3}$ Since then the Bank's researchers have updated the original RDV estimates of global poverty measures in the light of new and often better data. (Chen e Ravallion, 2008:2)

De forma sintética, se trata de uma medida que não reflete as diferentes realidades econômicas, históricas e culturais de cada país. No entanto, apesar disso, o Banco a estabeleceu como critério de pobreza indicado pela instituição para fundamentar o foco populacional das políticas de rede de segurança. Foi a partir dessa primeiro direcionamento do Banco Mundial que começaram a se desenvolver na América Latina, cuja participação do Banco descreveremos abaixo em detalhe.

Tabela 9 - Histórico de Investimento do Banco Mundial $^{32}$

\begin{tabular}{|c|c|c|c|c|c|c|}
\hline Lending & $1946-49$ & $1950-59$ & $1960-69$ & $1970-79$ & $1980-89$ & $1990-95$ \\
\hline \multicolumn{7}{|c|}{ Commitments (annual averages) } \\
\hline $\begin{array}{l}\text { Nominal (billions of U.S. } \\
\text { dollars) }\end{array}$ & 0.22 & 0.39 & 1.05 & 5.36 & 15.69 & 22.03 \\
\hline $\begin{array}{l}\text { Real (billions of } 1995 \text { U.S. } \\
\text { dollars) }\end{array}$ & 1.19 & 2.37 & 5.52 & 12.09 & 22.24 & 23.66 \\
\hline \multicolumn{7}{|l|}{ By regions (percent) } \\
\hline Africa & 0 & 15 & 12 & 14 & 15 & 1.5 \\
\hline Asia & 0 & 38 & 40 & 38 & 43 & 37 \\
\hline Europe & 81 & 20 & 12 & 12 & 9 & 16 \\
\hline Latin America & 19 & 22 & 28 & 24 & 26 & 25 \\
\hline Middle East/North Africa & 0 & 5 & 7 & 11 & 7 & 7 \\
\hline \multicolumn{7}{|l|}{ By sectors (percent) } \\
\hline Agriculture & 0 & 4 & 13 & 28 & 24 & 16 \\
\hline Finance and industry & 2 & 13 & 12 & 16 & 18 & $1 l$ \\
\hline Infrastructure $e^{a}$ & 21 & 61 & 64 & 36 & 29 & 24 \\
\hline Social $^{b}$ & 0 & 0 & 4 & 13 & 15 & 26 \\
\hline Other & 76 & 22 & 8 & 8 & 15 & 24 \\
\hline \multicolumn{7}{|c|}{ By lending instruments (percent) } \\
\hline Program and adjustment ${ }^{\mathrm{d}}$ & 76 & 21 & 6 & 5 & 18 & 20 \\
\hline Specific investment & 2 & 53 & 67 & 56 & 46 & 60 \\
\hline Other ${ }^{e}$ & 0 & 2 & 11 & 17 & 16 & 10 \\
\hline
\end{tabular}

A tabela acima expõem em números o histórico de investimentos da instituição em desenvolvimento. Nela pode-se notar, as seguintes evidências do que foi descrito ao longo desta parte do capítulo:

\footnotetext{
32 (Kapur et al, 1997:06)
} 
a) A diminuição progressiva de recursos destinados a Europa o que reflete o processo de mudança de foco da instituição da reconstrução ao desenvolvimento.

b) $\mathrm{O}$ crescente direcionamento de recursos para a América Latina e África o que também é indicativo da mesma mudança de rumos da instituição

c) O início tímido de investimentos sociais na década de 1970 e um salto quantitativo na década de 1990. Momento em que o Banco começa a direcionar valores significativos para a constituição do modelo das redes de segurança.

d) O grande aumento de recursos emprestados pelo Banco Mundial a partir da década de 1970 durante a gestão de Robert MacNamara.

e) $\mathrm{O}$ momento de maior investimento em infraestrutura coincide com as duas primeiras décadas da instituição. Momento em a promoção do desenvolvimento se resumia a promover estruturas de escoamento de produção para as ex-colônias.

No entanto, desenvolvimento social abarca também outros temas além da pobreza, como fome e promoção da igualdade. Em termos organizacionais, as políticas de combate a pobreza são agrupadas pela instituição sob o tema da proteção social em duas modalidades: a) as políticas de assistência social, que compreendem as transferências de renda, e b) as de seguro social. ${ }^{33}$

Social protection programs, which comprise both social assistance (such as cash transfers, school feeding, targeted food assistance and subsidies) and social insurance (such as old-age, survivorship, disability pensions, and unemployment insurance), are a powerful tool to reduce poverty and vulnerability. (World Bank social protection web page) ${ }^{34}$

As Transferências Diretas condicionais de renda, foco principal desta tese, são políticas que procuram fornecer suporte para os pobres (Barrientos,2010) e portanto não se enquadram na categoria de seguro social. A constituição de Redes de Segurança e todas as políticas associadas a este modelo estão alocadas sob a rubrica da assistência social.

\footnotetext{
${ }^{33}$ De acordo com Barrientos: Social insurance consists of programmes providing protection against lifecourse contingencies such as maternity and old age, or work-related contingencies such as unemployment or sickness. Social assistance provides support for those in poverty. Normally, social insurance is financed from contributions by workers and their employers, whereas social assistance is tax-financed." (Barrientos, 2010)

${ }^{34}$ World Bank Social Protection web page. Acessada dia 17 de maio de 2014.
} 
De acordo com o Banco, os valores investidos ou emprestados com o objetivo a prover suporte tecnológico e financeiro a constituição de redes de segurança já acumulam 11.5 Bilhões de dólares entre os anos 2000 e 2010:

During fiscal years 2000-10, the World Bank supported SSNs with $\$ 11.5$ billion in lending and an active program of analytic and advisory activities and knowledge sharing, much of it during the last two years in response to the triple crisis. (Banco Mundial, 2011:ix)

Os gráficos abaixo também evidenciam a intensificação dos empréstimos voltados ao combate a pobreza pelo Banco Mundial. Neles são apresentadas a serie histórica dos valores destinados especificamente a políticas de combate a pobreza entre os aos de $2001 \mathrm{e}$ 2008 explicita o aumento de recursos destinados a este fim.

Figura 13 - Emprestimos do Banco Mundial voltados a políticas de combate a pobreza ${ }^{35}$
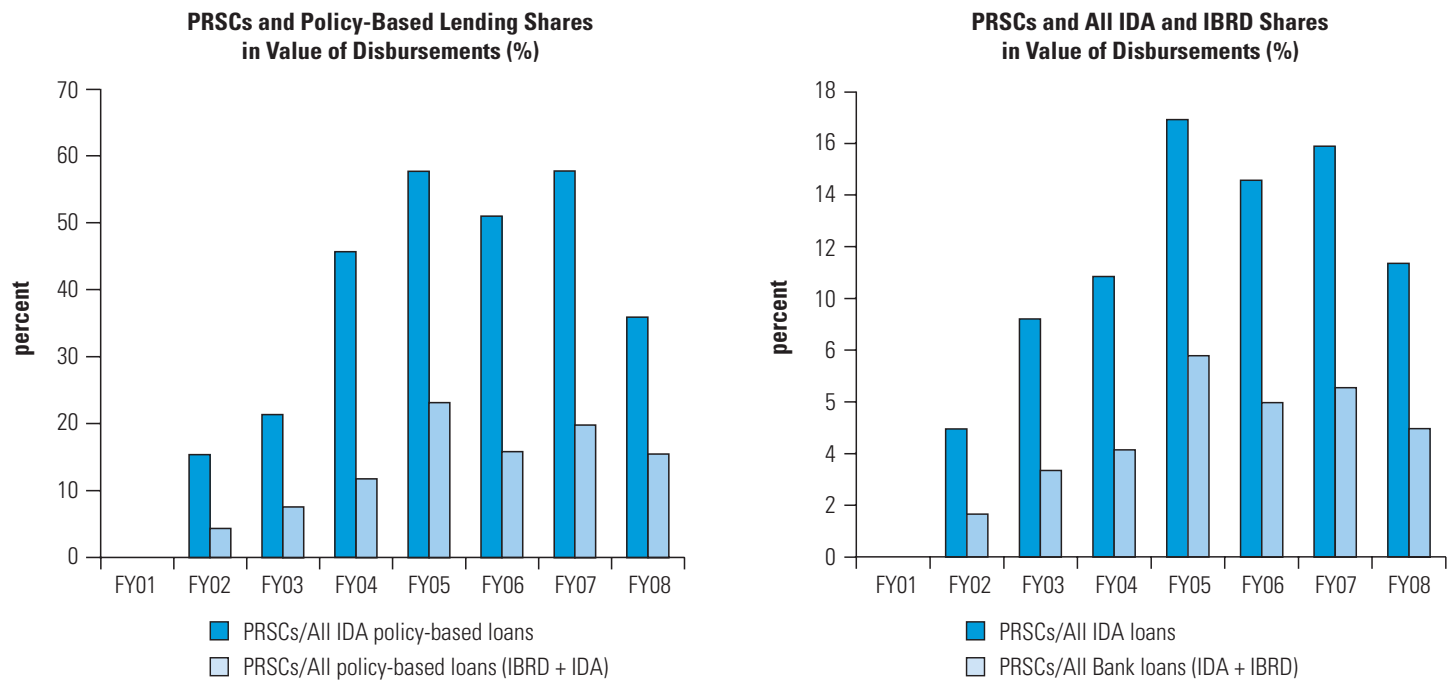

Com isso conclui-se este breve sobrevoo histórico ao Banco Mundial. De forma sintética procurou-se destacar três processos paralelos dos primeiros 60 anos de existência da instituição: a) a transformação de uma instituição financeira voltada a reconstrução e estabilidade para uma agencia de desenvolvimento, b) A ampliação da agenda do desenvolvimento do Banco Mundial em direção aos tema sociais, mais especificamente a pobreza e c) a influencia crescente do Banco Sobre os países do sul global.

\footnotetext{
${ }^{35}$ World Bank. 2010. Poverty Reduction Support Credits: An Evaluation of World Bank Support
} 


\section{O Banco Mundial e as Políticas de Transferência de Renda}

Se até o momento nos detivemos ao processo de aproximação do Banco Mundial a temática da pobreza, nesta parte iremos enfocar a promoção das Transferências Diretas Condicionais de Renda pela instituição como estratégia prioritária de combate a pobreza.

Como já foi apresentado no capítulo anterior, as redes de segurança são formadas de políticas públicas que visam a proteção social e passaram a ser promovidas pelo Banco Mundial após as crises geradas pelos ajustes estruturais. O tema social mais focalizado pelo Banco passou a ser a pobreza. O fluxo de expansão deste modelo continua em pleno movimento pelo sul global:

The global expansion of safety nets has included an increasing focus on low-income IDA countries. Among the 93 countries represented in the portfolio, 42 had no or limited exposure to WBG safety nets engagement prior to FY07. Africa was the region with most number of countries newly introduced to the portfolio. (World Bank Home Page ${ }^{36}$ )

De acordo com o próprio Banco Mundial, desde 2007, saltaram de 42 para 93 os países clientes do IDA - o grupo dos países mais pobres do mundo - que receberam financiamentos para a constituição de redes de segurança locais. Este número denota a crescente importância que esta estratégia de proteção social assume hoje para a instituição e, ao mesmo tempo, a intensidade de difusão da mesma.

Podemos dividir em duas etapas este movimento de incorporação das redes de segurança na agenda desenvolvimentista do Banco.

\section{a) Redes de Segurança como sistema de alívio a situações emergenciais de vulnerabilidade.}

A primeira, começa logo após a adoção dos ajustes estruturais e acompanha as primeiras percepções de que as consequências destas medidas. Diante disso, a partir de 1991, o

\footnotetext{
${ }^{36}$ Acessada no dia 17 de maio de 2014
} 
banco promove o chamado "poverty turn", na qual as redes de segurança são propostas como forma de dar assistência as populações mais vulneráveis em momentos de crise. A transferências diretas incondicionais de renda são uma das políticas que compõem esta estratégia.

O conceito de rede de segurança foi introduzida no Banco oficialmente em 1993, portanto quase 15 anos após a implementação dos ajustes, por meio do documento intitulado: Social Security Reforms and Social Safety Nets Report - divulgado na $47^{\mathrm{a}}$. reunião conjunta do Fundo Monetário Internacional e a Banco Mundial. (World Bank, 2011)

The experience of the 1980s led to the production of the World Development Report 1990 on poverty, which identified the most critical elements of poverty reduction as labor-intensive growth, investment in human capital, and safety nets for poor people. However, safety nets were still viewed as a "last resort"-reactive instruments dealing with the consequences of poverty but not its underlying causes. In this sense, safety net programs represented a cost to be minimized as opposed to an investment for which impact should be maximized. (World Bank, 2001:SP)

Foi desenhado neste momento, o fundamento desta estratégia de proteção social com o intuito de contrabalançar os efeitos negativos dos ajustes estruturais, como a própria instituição admite:

Recognized the importance of SSNs for mitigating major transitory adverse effects of economic reform on vulnerable groups to assist the poor and enhance the political viability of economic reforms. (Banco Mundial, 2011:90)

No entanto, este texto era mais de uma declaração de ajuste ideológico, do que um conjunto de direcionamentos e estratégias de ação e diversas experiências particulares começaram a ser desenvolvidas em nações periféricas, entres estas as TDCRs. (Para mais detalhes ver cap 2)

\section{b) A incorporação da ideia de Springboard as Redes de Segurança}

As the World Bank moves toward a broader understanding of poverty reduction and the relationship of risk to poverty, the standard concepts and interventions of social protection are no longer sufficient. This first sector strategy paper for social 
protection reflects this view and argues for the development of social protection programs that not only help poor women and men cope with the result of downturns (a safety net), but proactively help them take on higher return activities with less concern about the risks (a springboard). Such an approach provides the opportunity for people to move out of poverty whilestill providing support for those in most severe need. (World Bank, 2001:sp)

A partir de 2001 uma nova fase tem início no discurso e práticas do Banco. As redes de segurança deixam de ser percebidas como um instrumento de assistência emergencial e passam a agregar objetivos mais ousados. Trata-se da adoção da ideia de springboard (cama elástica) incorporando ao caráter meramente paliativo as redes de segurança também objetivos de longo prazo de combater a pobreza persistente nas gerações de famílias de baixa renda.

Este é o momento preciso em que o BIRD incorpora o modelo de TDCRs desenvolvidas na américa latina como política prioritária de combate a pobreza apoiada pelo Banco. Isso pois, estas estratégias agrupam tanto o alívio emergencial da vulnerabilidade econômica por meio das transferências diretas de renda - e indução da quebra dos ciclos geracionais de pobreza pelo investimento em capital humano - por mio da exigência de condicionalidades.

Os documentos mais importantes que estabeleceram e detalharam as novas diretrizes de empréstimos voltados a políticas de combate a pobreza para a instituição neste momento foram: a) o World Development Report de 2001 intitulado: Attacking Poverty: Opportunity, Empowerment, and Security em que o Banco Reafirma a necessidade de planos nacionais de Redes de Segurança para a as populações pobres para momentos de crise e transição econômica e b) World Bank Social Protection Strategy Paper: From Safety Net to Springboard em que as TDCRs começaram a ser definidas como principais recomendações para o combate a pobreza.

A transição conceitual que ocorreu na instituição alternou o modelo de redes de segurança direcionadas apenas ao contingenciamento de crise para o que eles chamam de springboard (cama elástica). Ou seja, era preciso agregar as RSS o objetivo de promover a quebra dos ciclos geracionais de pobreza. A passagem entre estas duas concepções de redes de segurança ocorreu 6 anos após o lançamento do Progresa/Oportunidades no México e do Bolsa Escola no Brasil. 
Foi também no ano de 2001 que o BIRD realiza os primeiros empréstimos direcionados a políticas de CCT de sua história, concedidos a Colômbia, Jamaica e Turquia. No ano seguinte, o Banco Mundial apoia a primeira conferência mundial de políticas de transferência condicional de renda, realizada no México. A segunda ocorreu no Brasil em 2004, ano de lançamento do Programa Bolsa Família e a terceira na Turquia em 2006.(Banco Mundial, 2010) Ainda no ano de 2006 estabeleceram-se as CCT Learning Cicles:

In late 2006, client countries with the most developed CCT programs in the region (Brazil, Chile, Colombia, El Salvador, and Mexico) asked the World Bank to act as a regional facilitator of knowledge, learning, and innovation for CCT programs. In response, the Latin America and the Caribbean Region created the CCT Learning Community, which client countries say has been a vehicle for innovation and just-in-time advice regarding CCT programs. (World Bank, 2011:22)

Estas iniciativas demonstram um processo de interação entre os estados nacionais e o Banco e os esforços destes actantes centrais a matriz do desenvolvimento para a difusão deste modelo. A disseminação destas praticas, portanto, são incentivadas tanto pelo financiamento dos programas locais de TDCR, quanto por trocas diretas de conhecimento por meio de publicações, apoios técnicos e conferências.

Em sua pagina virtual, o BM aponta três efeitos positivos desta estratégia como justificativa oficiais para a escolha das TDCRs como política social prioritária: a) estímulo a economia local, b) Investimento em Capital Humano por meio da exigência de condicionalidades e c) promove a possibilidade de empregos futuros melhores.

Stimulating local economies. Safety nets provided to poor households can have significant multiplicative effects on others in the local economy. In Malawi, a cash transfer program generated up to US\$2.45 additional income in local communities for every dollar provided to beneficiaries. In Lesotho and Mexico, similar programs are estimated to have, respectively, a multiplier effect of US $\$ 2.23$ and up to US\$2.60 per dollar.

Investing in human capital: education, health, nutrition. Conditional cash transfer (CCT) programs have increased school attendance in Bangladesh and Cambodia by 12 and $31 \%$, respectively. CCT programs in Colombia and Ecuador have bolstered health center visits for children by 33 and $20 \%$, respectively. In Guatemala, children under two years of age who benefited from a nutritional safety net program earned wages $46 \%$ 
higher as adults compared to those who did not benefit from the intervention.

Promoting better job opportunities in the future. The Oportunidades program in Mexico, a CCT currently reaching 6.6 million households, sparked demand for higher-level education and improved job prospects. Recent evaluations show that former beneficiaries are more likely to enter middle-class occupations than non-beneficiaries. And, this result is particularly significant for indigenous women who had participated in Oportunidades. (Wold Bank Home Page ${ }^{37}$ )

Desde então o Banco Mundial tem participado ativamente na disseminação das políticas organizando study tours dos casos latino-americanos de TDCR, em especial oportunidades do México, o famílias en accion da colômbia e o Bolsa Família no Brasil.

The World Bank has also helped disseminate CCT knowledge globally via study tours. Since 2001, the Bank has organized study tours of Oportunidades in Mexico, Familias en Acción in Colombia, and Bolsa Familia in Brazil for more than 30 other countries. The study tours are tailored to participant needs and have covered all aspects of CCT. (World Bank, 2011:22e23)

Nota-se portanto um duplo movimento entre o Banco Mundial e os Estados Nacionais Latino Americanos. Se por um lado o Banco foi instrumental em promover as políticas de ajuste estrutural e, diante das crises oriundas deste modelo, incorpora a necessidade a estratégia de redes de segurança. Por outro, as políticas de TDCR latino americanas, desenvolvidas principalmente no México e Brasil, serão encampadas como modelo prioritário de ação.

A partir daí se instala um esforço conjunto com os Estados Latino Americanos para a difusão desta estratégia ao restante do mundo em desenvolvimento. Atualmente as experiências de TDCRs ja expandiram até aos países desenvolvidos, como é o caso das cidades de Nova York e Washington nos EUA.

Este movimento de incorporação de uma experiência desenvolvida na américa latina, leva autores como Joseph Hanlon, Armando Barrientos e David Hulme (Hanlon et Al, 2010) e a afirmar uma revolução positiva vinda do sul. Atualmente 29 países possuem algum formato de TDCRs em funcionamento com apoio do Banco Mundial:

\footnotetext{
37 Acessada dia 17 de maio de 2014
} 
Ten years later, 29 developing countries had some type of CCT program in place (in some cases, more than one) and many other countries were planning one. The range of polities interested covers all continents, although the longest established and most evaluated programs are found predominantly in middle-income countries in Latin America. (World Bank, 2009: 31)

O Mapa abaixo ilustra a disseminação destas políticas de combate a pobreza até o ano de 2008. Nele pode-se notar que a maior concentração de países a adotar as TDCRS está América Latina, mas que este modelo já se espalha significativamente aos demais continentes.

Figura 14 - Mapa da evolução das TDCRs no mundo de 1997 a 2008

1997

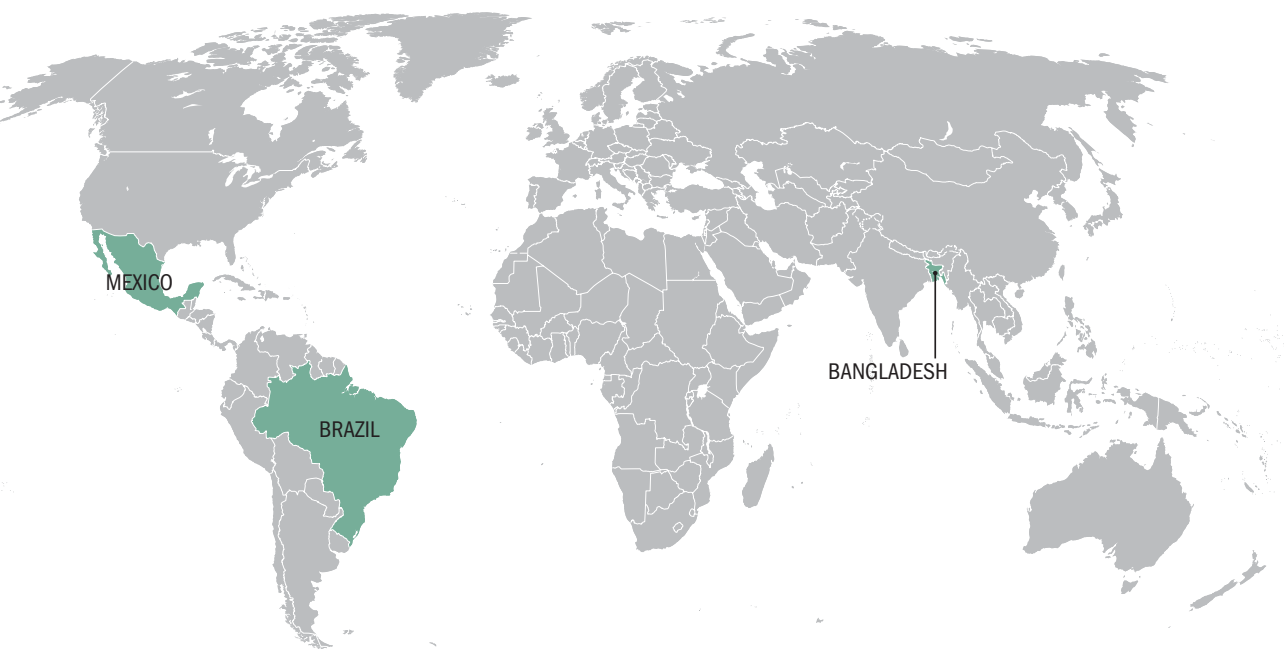

\section{8}

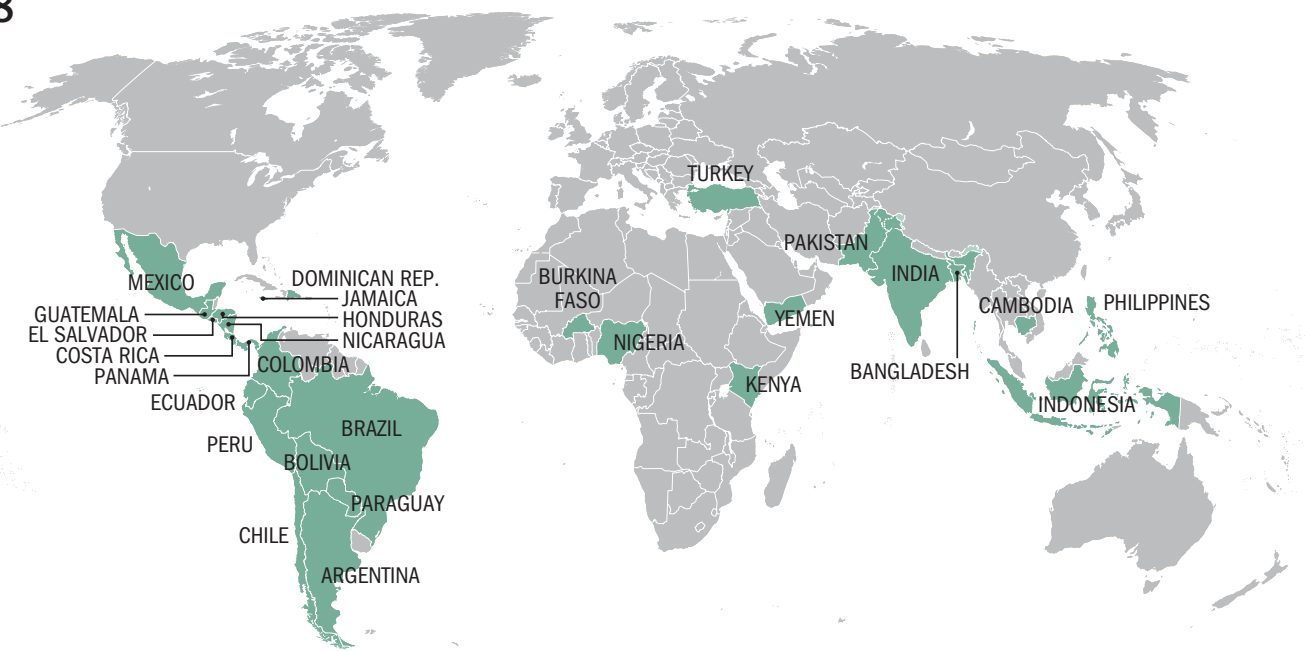


Esta diretriz operacional de promoção do modelo Latino Americano de TDCRs como estratégia de combate a pobreza segue em vigor na instituição até a atualidade. No dia 25 de Março de 2014, o atual presidente do BIRD, Jim Young Kim, publica no jornal brasileiro Valor Econômico ${ }^{38}$ um artigo intitulado: Por um mundo sem pobreza. Este artigo que ilustra o apoio da instituição a estratégias de TDCR de combate a pobreza extrema posicionando o Bolsa Família e o Brasil como centrais nesta busca:

Quando se trata de histórias de sucesso, o Brasil é, sem dúvida, um campeão. Entre 2001 e 2011, a pobreza extrema caiu pela metade de $9,7 \%$ para $4,3 \%$ da população. Um total de 22 milhões de pessoas foram retiradas da pobreza - o que é mais do que a população de países como Angola ou Romênia. Além disso, em contraste com muitos países de renda média, a desigualdade diminuiu durante esse mesmo período. Estas conquistas impressionantes devem-se a mais do que apenas uma economia crescente e um mercado de trabalho dinâmico. Elas devem muito à concepção e implementação pioneira de programas sociais inovadores no Brasil, com o Bolsa Família (BF) como exemplo mais proeminente. (Valor Econômico, 2014)

38 Por um Mundo sem pobreza. Valor Econômico dia 25/03/2014 


\section{Conclusões: O Banco Mundial e o projeto hegemônico de desenvolvimento.}

O Banco Mundial analisado aqui por sua posição de protagonista institucional do projeto hegemônico do desenvolvimento teve papel decisivo para a elaboração e difusão das Transferências Diretas Condicionais de Renda como estratégia de combate a pobreza.

Deste capítulo destacam-se quatro pontos entre todos que foram abordados:

1. As Transferências Diretas Condicionais de Renda são o ultimo capítulo de um processo de expansão da agenda desenvolvimentista do Banco Mundial.

O desenvolvimento que era visto nos primeiros anos de existência do BIRD como um sinônimo de crescimento da economia foi aos poucos se ampliando em direção as temáticas sociais, em especial o combate a pobreza.

Ao longo deste processo, as diretrizes de investimento do BM foram paulatinamente voltadas para o desenvolvimento social e chegou hoje a ser a maior rubrica de empréstimos da instituição

2. A incorporação das TDCRs as políticas defendidas pelo Banco Mundial são o resultado direto das crises econômicas geradas pelos Ajustes Estruturais

A imposição dos ajustes estruturais ao países do sul global ocorrida em meio a fragilidade econômica destas nações ao longo da década de 1980 resultou em um quadro social de aumento da desigualdade e pobreza na periferia do capitalismo.

Diante deste cenário, no início da década de 1990, o Banco Mundial realiza o chamado Poverty Turn. Trata-se de um redirecionamento do foco da instituição ao desenvolvimento social e combate a pobreza. Neste momento o Banco passa a defender a constituição de redes de segurança nos países periféricos para dar suporte emergencial as populações economicamente vulneráveis em momentos de crise. Foi diante deste direcionamento que muitos países do sul global passaram a desenvolver as primeiras experiências com Transferências Diretas de Renda.

No início da década de 2000 o Banco reformula esta abordagem em direção ao que eles denominam Springboard. Por esta perspectiva, as redes de segurança deveriam fornecer 
mais do que alívio e incorporar medidas para estimular o capital humano das famílias de baixa renda com o objetivo de gerar mudanças de longo prazo.

Nesta etapa o Banco adota o modelo latino-americano de TDCR, por este contemplar tanto o alívio a vulnerabilidade econômica quanto o investimento em capital humano

3. Dois movimento podem ser identificados no processo de desenvolvimento das TDCRs.

Por um lado o Banco Mundial influencia a disseminação das pol;iticas de rede de segurança como forma de lidar com os problemas sociais advindos dos ajustes estruturais. Trata-se de um fluxo hegemonico possibilitado pelas relações assimetricas estabelecidas entre o Banco e as nações periféricas.

Por outro nota-se a adoção pelo BIRD de um modelo de Transferência Direta Condicional de Renda desenvolvido pelos países latino-americanos. Esta incorporação pode ser vista como um fluxo hegemonizado de sentido sul-norte. Isso pois, ao mesmo tempo em que estes países se submetem ditames do modelo de proteção social promovido pelo BM exercem influencia decisiva sobre o mesmo.

4. A agenda e as ações do Banco Mundial explicitam algumas características do discurso hegemônico sobre o desenvolvimento.

a) a perspectiva linear e universalista que a ideia de progresso assume em seu discurso.

A incorporação pelo Banco Mundial de um visão etapista de desenvolvimento durante o domínio ideológico da teoria da modernização e a aplicação de maneira generalizada das medidas do consenso de Washington ao longo hegemonia neoliberal pala instituição são evidência desta característica da narrativa hegemônica do desenvolvimento.

b) A quebra espacial que divide as nações 
A divisão das nações a partir do critério linear de renda percapta, estabelece as fronteiras entre desenvolvidos e não-desenvolvidos, centro e periferia ou sul e norte global.

c) A cartografia do desenvolvimento como um projeto etnocêntrico e civilizador de sentido norte-sul.

A utopia ou o destino apontado pelo projeto hegemônico do desenvolvimento nada mais é do que uma reprodução do modelo societal do norte capitalista. As contínua ampliação da agenda de desenvolvimento do Banco é uma das evidencias deste aspecto.

5. A difusão das TDCRs como estratégia de combate a pobreza são hoje promovidas tanto pelo Banco Mundial como pelos países do sul global.

As Transferências Diretas Condicionais de Renda hoje já extrapolam o continente sul americano. Tanto os canais de diálogo sul-sul quanto a ação do Banco Mundial tem papel importante neste processo que já atinge mais de 35 países pelo mundo. 
Parte III - A Índia. 


\section{Introdução}

Este tese não tem a intensão de se restringir a descrição de um processo histórico. Como já apresentamos nos capítulos anteriores a difusão das Transferências Diretas Condicionais de Renda é um fenômeno vivo e em pleno andamento. A análise histórica forneceu evidências de um processo macro-sociológico que procurou identificar as vinculações ideológicas, contexto e actantes envolvidos.

No entanto, limitar-se a busca das linhas gerais que caracterizam este processo difusório privaria esta pesquisa dos aspectos singulares que ocorre em cada país afetado por este fluxo. Além disso, esta postura procura evitar o silenciamento da diversidade das sociedades do sul global que marca tanto o discurso das agencias multilaterais quanto da teoria hegemônica do desenvolvimento.

Como já demonstramos no caso do surgimento do Programa Bolsa Família no Brasil, tanto o cenário interno como as particularidades internas do país tiveram efeito sobre a implementação da política. O mesmo é verdadeiro para todos os países atingidos por este fluxo.

As diferenças podem ser de diversas ordens. No caso dos países latino-americanos os programas de TDCR são majoritariamente financiados pelos governos nacionais, já " $4 p$ program" das Filipinas, a totalidade dos recursos são oriundos do Banco Mundial (Giugliano, 2012). Nos casos de países como Egito e Turquia os recursos são transferidos aos homens chefes de família, já no caso do Oportunidades do México são destinados as mulheres. (Soares, 2010)

Outro fator também foi fundamental para conduzir esta pesquisa para além de uma descrição histórica. Como afirmamos na introdução, nos interessamos aqui pela crescimento do diálogo sul-sul e seus impactos sobre o campo do desenvolvimento.

Como os capítulos anteriores já demonstram, a difusão das TDCRs não pode ser caracterizado como um movimento exclusivamente de sentido sul-sul pela importância que o Banco Mundial exerce no processo. No entanto, esta estratégia é promovida também por meio dos canais de diálogo entre as nações periféricas.

O Brasil é um dos maiores promotores das TDCRs como modelo de combate a pobreza. Nos fóruns em que o país participa a experiência com o Bolsa Família é divulgada e 
compartilhada e compartilhada com as demais nação. São muitos os fóruns em que esta divulgação ocorre, como já dissemos acima, os encontros internacionais e os CCts learning cicles constituem dois exemplos destas práticas.

Estes dois fóruns, no entanto, não constituem um exemplo claro de diálogo sul-sul, uma vez que consta com apoio e participação significativa do Banco Mundial. Para escolher casos que pudessem não só fornecer evidências sobre a difusão das TDCRs como de possíveis impactos das relações sul-sul sobre este processo foram escolhidos para análise dois casos em que as TDCR se encontravam em processo de implementação: a Índia e a África do sul.

Esta escolha foi baseada na participação dos três países no IBAS - Fórum de Diálogo entre Índia, Brasil e África do Sul. Um dos grupos de trabalho deste fórum é dedicado ao desenvolvimento social e as temáticas mais recorrentes foram a pobreza e os programas de transferência de renda.

Além disso, tanto a Índia quanto a África do Sul se encontram em fases diferentes de implementação de programas de TDCR e citavam recorrentemente em documentos oficiais os programas Brasileiros de transferência de renda como um dos principais modelos a serem seguidos.

De maneira sintética, a análise destes casos tem um duplo objetivo: a) trazer a tona indicativos do funcionamento e limitações do processo de difusão de fórmulas universalizantes de combate a pobreza pelo sul global e b) identificar possíveis efeitos do diálogo sul-sul sobre este processo.

A longo de nove meses na cidade de Nova Delhi na Índia e três meses divididos entre as cidades de Pretória e Cabo na África do Sul, procurei coletar dados e análises do processo que estava em curso em cada uma dos países. Três foram as fontes utilizadas como evidências da implementação das TDCRs: a) documentos institucionais dos órgãos estatais responsáveis pelas políticas de desenvolvimento e instituições multilaterais envolvidas; b) entrevistas com membros do governo e pesquisadores locais e, claro, c) pesquisa bibliográfica entre as referências acadêmicas. Neste último ponto procurou-se dar peso maior possível aos autores locais, em busca de uma escuta da perspectiva interna da questão aqui abordada. 
A Índia se mostrou terreno mais fértil de pesquisa. Isso pois, o governo nacional segue implementando TDCRs e que suscitou um amplo debate interno. Foi possível perceber alguns dos impactos sobre a definição de pobreza no país e testemunhar as primeiras experiências práticas destas políticas.

A África do Sul, no entanto, se mostrou um lócus de pesquisa menos fértil. A implementação do Programa Zero Hunger que seria alvo da investigação desta tese foi paralisado ao longo do ano de 2013, fato que limitou os dados disponíveis e a análise aqui pretendida e inviabilizou a presença de um capítulo sobre o país. 


\title{
Capítulo 5 - As Transferências Diretas de Renda Chegam a Índia
}

\author{
Índia, sobrevoo e aterrisagem.
}

\begin{abstract}
"India's independence represented for its people the start of an epoch that was imbued with a new vision. In 1947, the country commenced its long march to overcome the colonial legacy of economic underdevelopment, gross poverty, near total illiteracy, wide prevalence of disease and stark social inequality and injustice. 15 of august 1947 was only the first stop, the first break - the end of the colonial political control; centuries of backwardness were now to be overcome, the promises of the freedom struggle to be fulfilled, and people's hope to be met." (Chandra, 1999:01)
\end{abstract}

O Historiado Bipan Chandra, descreve o nascimento do jovem Estado-Nação Indiano como um primeiro rompimento com o perverso legado social da colonização e, justamente por isso, o desenvolvimento se constitui como a principal missão do novo país. O Estado Indiano e o desenvolvimento são elementos inseparáveis de uma mesma equação. O trecho do famoso discurso Tryst with Destiny" de Jarwarhalal Nerhu na ocasião da independência, ilustra este compromisso:

Freedom and power bring responsibility. The responsibility rests upon this Assembly, a sovereign body representing the sovereign people of India. Before the birth of freedom, we have endured all the pains of labour and our hearts are heavy with the memory of this sorrow. Some of those pains continue even now. Nevertheless, the past is over and it is the future that beckons to us now. That future is not one of ease or resting but of incessant striving so that we might fulfil the pledges we have so often taken and the One we shall take today. The service of India means the service of the millions who suffer. It means the ending of poverty and ignorance 
and disease and inequality of opportunity. The ambition of the greatest man of our generation has been to wipe every tear from every eye. That may be beyond us but as long as there are tears and suffering, so long our work will not be over. (Nerhu, 1947)

A dominação ocidental sobre a Índia é recente e só tive início com expansão ultramarina europeia renascentista. Antes de 1498, ano do desembarque de Vasco da Gama em Calicut, apenas Alexandre o grande tinha se aventurado com uma força invasora europeia na península. No entanto, a campanha macedônia de 325 AC deixou poucos traços.

Os primeiros avanços dos impérios coloniais europeus sobre o território indiano tiveram caráter pontual, por meio de feitorias, posses territoriais restritas e alianças com governos locais. (Chandra, 1985) Este quadro se transforma a partir de 1757, quando o subcontinente testemunha a ampliação do controle colonial inglês. A dominação britânica, supera os concorrentes portugueses, franceses e holandeses, unificando pela primeira vez toda a península sob uma única administração, desde as fronteiras do atual Afeganistão até os confins Burma.

Foram 449 anos de presença colonial na região antes que a luta indiana pela independência alcançasse seu principal objetivo. A etapa final do processo de libertação nacional ocorrida em $1947^{39}$ foi consensual é apenas o último instante de uma longa história de revoltas e conflitos que assolou o território durante a presença das forças coloniais.

De acordo com Chandra (1999), a independência indiana foi, ao mesmo tempo, resultado da busca de rompimento dos laços subalternos com a metrópole e do esforço para constituir uma unidade política e territorial. A utopia nacionalista previa a unificação do território e todas as diferenças que nele coabitavam sob uma nação plural e secular.

The foundation of the Indian National Congress in 1885 was not a sudden event, or a historical accident. It was the culmination of a process of political awakening that had its beginnings in the $1860 \mathrm{~s}$ and 1870 s and took a major leap forward in the late 1870 s and early 1880 s. The year 1885 marked a turning point in this process, for that was the year the political Indians, the modem intellectuals interested in politics, who no longer saw themselves as spokesmen of narrow group interests, but as representatives of national interest vis-a-vis foreign rule, as a 'national party,' saw their efforts bear fruit. The all-India nationalist body that they brought into being

\footnotetext{
${ }^{39}$ Promulagada a partir de 18 de Julho de 1947 pelo parlamento ingles a: indian independence act
} 
was to be the platform, the organizer, the headquarters, the symbol of the new national spirit and politics. (CHANDRA, 1999:45)

A instituição que congregou os esforços independentistas indianos foi o Congresso Nacional Indiano - CNI. Movimento amplo que unia forças de origem e matizes muito diversas, cujos líderes mais conhecidos foram Jawarhalal Nerhu e Mahatma Gandhi. Fundado em 1885 o congresso buscava capitalizar e dar institucionalidade ao desejo de independência Indiana.

To make myself clearer, the path that India has followed since 1947 has deep roots in the struggle for independence. The political and ideological features, which have had a decisive impact on post-independence development, are largely a legacy of the freedom struggle. It is a legacy that belongs to all the Indian people, regardless of which party or group they belong to now, for the 'party' which led this struggle from 1885 to 1947 was not then a party but a movement all political trends from the Right to the Left were incorporated in it. (CHANDRA, 1985:02)

Em agosto de 1947, enfim, foi erguida a bandeira de uma Índia independente no forte vermelho de Delhi. No entanto, a aprovação do ato de independência indiano pelo parlamento inglês foi condicionado a aceitação do que se convencionou chamar de primeira partição. O Congresso Nacional Indiano que até então defendia a manutenção da unidade territorial dos domínios ingleses para a formação do novo estado independente aceitou a partição dos territórios do West Punjab e West Bengal. O resultado foi a constituição de dois novos países, o Dominion of Paquistan - que posteriormente se separam originando o Paquistão e Bangladesh - e a Indian Union.

A hard-earned, prized freedom was won after long, glorious years of struggle but a bloody, tragic Partition rent asunder the fabric of the emerging free nation. (Chandra, 1999:494)

A partição resultou em um enorme êxodo populacional marcado por tal violência sectária que o evento é considerado caso de genocídio nos termos definidos pelas nações unidas (Panigrahi, 2004)

A fascinante história, tanto da Índia pré-colonial quanto colonial, certamente ainda impacta sobre a realidade contemporânea do subcontinente. Este trabalho, embora restrito ao período pós-colonial, novo estado nação deve a herança colonial a centralidade que o tema desenvolvimento assume. (Ghosh e Chandrakkar, 2011) 
Ao longo do período colonial não pode-se dizer que havia preocupação direta com o desenvolvimento do país:

\begin{abstract}
During the colonial era, government's economic policies in India were concerned more with protecting and promoting British interests than with advancing the welfare of the Indian population. The administration's primary preoccupation was with maintaining law and order, tax collection and defence. These activities absorbed the bulk of the meagre public revenues. As for development, government adopted a basically laissez-faire attitude. (vaidyanathan, 1983:947)
\end{abstract}

Segundo Chandra, a economia colonial pode ser caracterizada por quatro aspectos fundamentais: a) integrou de forma subordinada a economia indiana ao sistema mundo de então, b) a produção indiana foi limitada a exportação de produtos primários e importação de bens manufaturados, c) a transferência de parte da riqueza gerada na colônia diretamente a metrópole e d) a submissão das decisões econômicas sobre a Índia ao poder central em Londres.

Tal configuração é vista pelo historiador marxista como causa estrutural da condição de pobreza em que a Índia se encontrava após a independência. Basicamente, a economia do país se restringia, após a desmonte da produção manufatureira tradicional, a produção agrícola (vaidyanathan, 1983 e Ghosh 2011) A superação desta condição se constituiu como a primeira grande meta econômica do novo país. Abordaremos no seguimento alguns dos processos realizados pelo país deste de então.

A Índia contemporânea, de acordo com o censo demográfico de 2011, tem de 1,2 bilhão de habitantes. O país sustenta uma taxa de crescimento médio anual de $1.65 \%{ }^{40}$. Caso mantenha este ritmo, o país contará com a maior população do mundo em menos de uma década. Superaria então a China que hoje possui uma população estimada de 1.3 bilhão de habitantes. Essa projeção é motivo de orgulho para muitos dos indianos com que tive contato ao longo da pesquisa de campo.

Do total populacional, apenas $31,3 \%$ vive em áreas urbanas. Uma importante diferença com a realidade brasileira, onde dois terços dos habitantes vivem em cidades. (censo demográfico 2011)

\footnotetext{
${ }^{40}$ Média entre os anos de 2001 e 2011 segundo o censo demográfico indiano de 2011.
} 
Uttar Pradesh, ou UP - como é chamado localmente - é um estado com dimensões territoriais aproximadas as de São Paulo, e possui a maior densidade demográfica do subcontinente. No ano de 2011, ainda de acordo com o Censo, o estado contava 200 milhões de habitantes - equivalente ao total populacional brasileiro. (censo demográfíco 2011)

Vinte e duas línguas são reconhecidas oficialmente pela constituição de 1950. O Hindi é a mais falada delas $-41 \%$ da população. O hinduísmo é praticado por $81 \%$ dos indianos, os demais se dividem em: 13,4\% de muçulmanos, 2,3\% de cristãos e 1,3\% de Sihks. (governo Indiano)

A Republica da Índia, ou Bharatiya Ganarajya, é composta - em termos de organização política/territorial - por 28 estados e 7 territórios federais. Oficialmente se declara uma república soberana socialista, secular e democrática com um sistema parlamentar de governo. O presidente é chefe de estado e primeiro ministro líder de governo.

Mesmo este conjunto de dados, usados aqui apenas como sobrevoo introdutório, mal principiam a descrever a diversidade Indiana. Confesso só ter realmente percebido desta diversidade ao me defrontar pela primeira vez com o acachapante e hipnotizante caos das ruas de Nova Delhi.

Como afirma Amartya Sen:

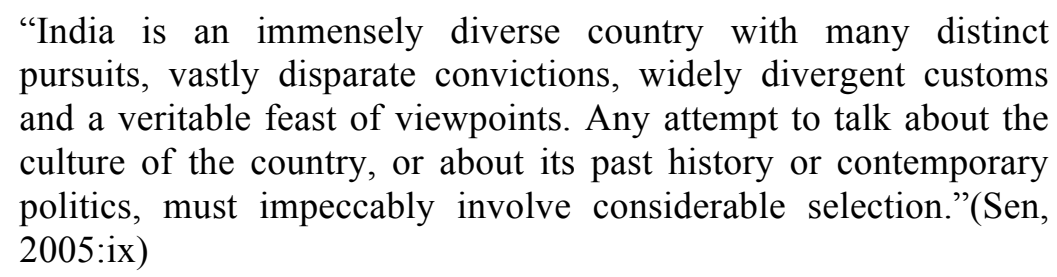

Em acordo com o autor, esta tese propõe uma seleção considerável e um recorte cuidadoso, inevitáveis a viabilização deste estudo. Neste processo buscou-se, ao mesmo tempo, não simplificar a realidade local de maneira a descaracterizar os seus efeitos sobre o objeto, mas reduziu-se o escopo de análise de forma limitá-la as possibilidades de tempo e recursos aos quais esta pesquisa se limita. O primeiro destes, como já descrito acima, é o de focalizar a Índia independente pós-1947.

Outro aspecto relevante é que não se pretende aqui abordar a Índia como nação, nos limitaremos ao Governo Central Indiano e o impacto específico sobre este agente das políticas de TDR. 
A diversidade interna e a autonomia das regiões, se abordadas aqui, certamente evidenciariam um conjunto rico e diverso de tratamentos e definições sobre a pobreza. No entanto, não é este caminho que esta pesquisa trilhou.

O foco no Estado Nacional possui um conjunto de motivações. Primeiro, este ator se posiciona na fronteira entre as influencias externas e as pressões internas a seu território. $\mathrm{O}$ governo nacional Indiano, como agente institucional, possui assento nos fóruns mundiais onde o conhecimento sobre as TDCRs trafegam - Banco Mundial, FMI, IBSA e BRICS.

Terceiro, o próprio movimento de independência e o Estado nascente declaram como seu maior desafio a superação da condição econômica e social deixada pelo período colonial. O que faz da questão social inseparável do próprio surgimento do país. (Chandra et all 2008)

\section{O Estado Nacional Indiano e o desenvolvimento}

Nesta parte do texto realizaremos um breve sobrevoo histórico pelas estratégias de desenvolvimento adotadas pelo Estado Indiano desde a independência. Por se tratar de uma história longo a complexa, vamos nos ater apenas a três momentos chave deste processo.

Como afirma Jayati Ghosh (2011), na história da Índia independente três estratégias gerais para o desenvolvimento podem ser percebidas: a) a economia planejada implementada logo após a independência, b) A liberalização promovida pelo Segundo Governo Indira Gandhi e continuada por seu filho Rajiv Gandhi e c) e a chegada do Neoliberalismo ao país na década de 1990 .

The Industrial Policy Resolution of 1948 signalled acceptance of the principle that the government will have a major role in initiating and regulating development in one of the key sectors of the economy. The directive principles of state policy incorporated in the Constitution defined the broad objectives of socio-economic policy. They mentioned the right of citizens to an adequate means of livelihood, regulation of ownership and control of material resources for the common good and the avoidance of concentration of wealth and means of production. Finally, the concept of a coordinated planning of development programmes 
under the auspices of the central government was accepted, and the

Planning Commission set up in January 1950.

(Vaidyanathan,2008:949

De acordo com Vaidyanathan (2008), a escolha por um modelo de desenvolvimento baseado em uma economia planificada evidência a centralidade que o Estado como o grande indutor do progresso. Atualmente o planejamento econômico ainda figura oficialmente como método de organização das políticas do país, no entanto aos poucos a força deste instrumento foi se diluindo. O Governo atual de Naredra Modi ${ }^{41}$ tem anunciado que irá extinguir a comissão nacional de planejamento, o que pode ser um sinal do abandono completo está por vir. (Patnaik, 2014)

O modelo indiano inicial de planificação econômica teve como base o modelo soviético da década de 1950 e evidencia a aproximação ideológica de Nerhu ao socialismo. De acordo com este formato, a cada 5 anos, os objetivos nacionais deveriam ser reavaliados e redirecionados Estado. O órgão criado para realizar esta tarefa foi a Indian Planing Commision - IPC, criada em março de 1950. (Chandra, 1999) Esta instituição, desde sua criação, assume um papel central nos caminhos de desenvolvimento adotados pelo país. Pela importância da IPC, dedicaremos parte específica deste capítulo a história e o papel deste órgão na definição dos rumos do combate a pobreza.

A principal meta do primeiro plano de desenvolvimento era a de promover a industrialização do país. (Srivastan, 2012) Este caminho representou a vitória da perspectiva econômica defendida por Nerhu sobre os demais participantes do CNI. As correntes tradicionalistas e liberais que também compunham o espectro ideológico do grupo e rechaçavam tanto a industrialização como a planificação foram relegadas a uma condição secundária. (Chandra, 1999)

A visão tradicionalista Gandhiana, por exemplo, exibia uma complacente aceitação de um suposto status natural da desigualdade, ao mesmo tempo, em que resistia a ocidentalização e a adoção do sistema capitalista de acumulação no país. As palavras de Gandhi abaixo transcritas evidenciam a postura do líder indiano:

I cannot picture to myself a time when no man shall be richer than another. But I do picture to myself a time when the rich will spurn

\footnotetext{
41 http://www.business-standard.com/article/news-ani/pm-narendra-modi-announces-scrapping-of-planningcommission-114081500184_1.html
} 
to enrich themselves at the expense of the poor and the poor will cease to envy the rich. Even in a most perfect world, we shall fail to avoid inequalities, but we can and must avoid strife and bitterness. (YI, 1926, p. 348)

A aproximação do governo de Nerhu ao desenvolvimento não se restringiu a planificação e centralismo. $\mathrm{O}$ então mandatário indiano foi também um dos fundadores do movimento dos países não-alinhados. Esta participação conectou o governo ao pensamento econômico estruturalista de Raul Prebisch e a estratégia a substituição de importações como caminho a industrialização. (Vaidyanathan, 2008) Assim tanto a planificação como o protecionismo caracterizam esta primeira fase do desenvolvimento indiano.

Prasanta Chandra Mahalanobis, considerado o pai do planejamento econômico indiano, foi o economista que liderou os primeiros esforços desenvolvimentistas da nação. Influenciado por Arthur Lewis e Raul Prebisch elaborou a primeiro plano nacional de industrialização e crescimento econômico. (Srivastan, 2012)

O plano Nerhu-Mahalanobis priorizava o crescimento de quatro setores da economia indiana: a) Bens de Capital - em especial a indústria pesada; b) Bens de Consumo; c) Agricultura e pequenas Industrias e o d) O setor de serviços. (Srivatsan, 2012).

\footnotetext{
"The division of the economy into four sectors permits a relative priorization of investment in heavy industry, consumer goods, agriculture and the service industry. In addition, unlike the Lewis model, Mahalanoubis explicit second goal is to ensure a specifically planned growth of actual employment. He also envisages a degree of redistribution (welfare measures) through taxation to minimize the hardship of transition to an industrial economy. The primary goal is economic goal, and the decision to spend in other sectors is tempered by this goal."(Srivatsan, 2012:15)
}

A pobreza e a desigualdade não recebeu neste momento um tratamento especifico, uma vez que a erradicação desta condição viria, segundo as teorias da épocas, consequência natural do processo de desenvolvimento. Portanto, assim como o Banco Mundial, o governo indiano não promovia políticas diretas de combate a pobreza, pois o bem estar da população seria garantido pelo efeito trickle down que difundiria a riqueza a gerada pelo crescimento econômico a todas as classes sociais.

No entanto, Malanoubis, como afirma Srivastan, reconhecia que a transição para uma economia industrial traria dificuldades e problemas sociais e, portanto, seria necessário 
garantir algumas medidas para amenizar tais dificuldades. A principal destas foi a manutenção do Public Distribution System - PDS, sistema de distribuição de alimentos criado durante a segunda guerra para combater a fome e altamente dependente de doações externas.

Com a morte de Nerhu em 1964 inicou-se uma disputa interna para escolher seu sucessor. Após dois anos conturbados de governo instável, Indira Gandhi - filha de Nerhu - assume a liderança da nação. A princípio, no que diz respeito as estratégias para o desenvolvimento, isso significou a manutenção da estratégia iniciada após a independência.

No entanto, já no início do novo governo os primeiros sinais de que o modelo de planificação econômica adotado pelo país caminhava ao colapso começam a aparecer.

The 1960s and 1970s showed India was still vulnerable to the effects of failed monsoons, droughts and food shortages: in 1965-6 India was forced to turn to the United States for grain imports and Mrs Gandhi was obliged to devalue the rupee.The Green Revolution brought some respite by increasing domestic grain yields, but the benefits were unevenly distributed regionally - the Punjab, Haryana and Tamilnadu were the states where the new varieties were most successfully introduced - and socially, with agrarian labourers experiencing few of the rewards reaped by rich peasant farmers. India's vast internal market failed to flourish without external competition to encourage innovation or to promote higher levels of performance and productivity. Some leading industries such as cotton textiles experienced overcapacity and mills in Bombay and Kanpur fell idle. (Stein, 2010:414)

A industrialização pretendida por Nerhu não se realizou e a agricultura ainda era muito pouco resistente as irregularidades climáticas e, portanto, de ajuda financeira externa. Esta realidade forçou o governo de Gandhi a alterar as estratégias tanto de desenvolvimento quanto de políticas sociais.

Indira Gandhi exerceu o cargo de primeira ministra por duas vezes, sendo a primeira entre 1966 e 1977 e a segunda entre 1980 e 1984. Os dois períodos tem características muito diferentes entre si. No entanto, ambos evidenciam um redirecionamento da economia em direção ao uma maior abertura e liberalização. (Stein, 2010)

Outra divergência entre o período Nerhu e Gandhi pode ser notado no âmbito do desenvolvimento social. Durante o governo da filha do líder independentista, o combate a pobreza foi elevado a condição de tema central nas preocupações do estado indiano. $\mathrm{O}$ 
principal lema da gestão Indira Gandhi foi: garibi hatao ("eradicate poverty") (Kohli, 1987)

Apesar deste bordão, as ações sociais mais significativas do governo Indira Gandhi para o combate a baixa renda ocorreram no campo da segurança alimentar. Este fato demonstra que o tema da pobreza ainda não era endereçado de maneira isolada, mas, pelo contrário, como um fenômeno resultante de problemas estruturais como a baixa industrialização e a fome.

Como já dissemos acima, Gandhi havia recebido uma herança difícil do governo de seu pai uma vez que os primeiros planos econômicos do país não haviam surtido o efeito esperado. Além disso, uma longo período de estiagem agravou a fome e a guerras com China e Paquistão afetaram o cenário negativo daquele momento. Como afirma Chandra:

\begin{abstract}
It was, however, the economic situation which was intractable. The economy was in recession and fast deteriorating. Industrial production and exports were declining. The rains failed for the second successive year in 1966, and the drought was more severe than in 1965, and led to galloping inflation and grave food shortages. Famine conditions prevailed in large parts of the country, especially in Bihar and eastern U.P. The wars of 1962 and 1965 and the Pakistan-China axis had led to a sharp rise in military expenditure and diversion of resources from planning and economic development. Budget deficits were growing, endangering the Fourth Five Year Plan. The situation required hard decisions and their firm enforcement, but the government vacillated, was slow in taking decisions and, what was even worse, tardy and ineffective in implementing them. In particular, it could not reduce its own bloated administrative expenditure which the financial situation required. (Chandra, 1999:222)
\end{abstract}

O governo de Gandhi, para lidar com esse quadro, passou a promover a abertura econômica do país. Juntamente com esta medida iniciou-se um fracassado programa de diminuição dos gastos governamentais e controle de preços para conter a inflação.

No campo do desenvolvimento social três iniciativas foram implementadas para tentar garantir a segurança alimentar. A primeira foi a chamada revolução verde. Como afirma Stein (2010)

1960s with the introduction of a package of improvements in rice and wheat cultivation consisting of a combination of new highyield seed varieties, chemical fertilizers and pesticides and irrigation based upon tube-wells, elec- tric pumpsets and 
widespread electrification. The result was a quantum leap in grain production. (Stein, 2010:376)

No entanto, de acordo com Chandra, apesar do sucesso no aumento da produção agrícola o novo sistema beneficiou apenas a agricultura capitalista de larga escala. Isso pois, a incorporação de novas técnicas e materiais exigiam altos investimentos que eram incompatíveis com os ganhos dos pequenos produtores.

Outra medida que marca a gestão de Indira Gandhi foi a universalização do Public Distribution Sistem - PDS. A distribuição de alimentos, até então restrita a áreas em situação de emergência, passou a ser garantida como um direito fundamental do cidadão indiano que passou a poder adquirir uma quantidade limitada de produtos nas lojas subsidiadas pelo governo.

Por fim, ocorreu também ao longo do primeiro governo Gandhi a reformulação da legislação sobre a terra e posse nos anos 70. As leis foram alteradas para impedir os regimes de submissão dos trabalhadores sem terras próprias e a proteção dos pequenos produtores (Kohli, 1987)

Mesmo com o sucesso alcançado no campo da segurança alimentar, o crescimento econômico permanecia tímido, assim como a industrialização do país. O resultado foi a manutenção dos índices nacionais de pobreza. Em 1977 este quadro social precário cobrou seu preço o governo de Indira Gandhi foi substituído por seus opositores.

Mais uma vez um quadro de instabilidade política e inabilidade dos governos eleitos que durou 3 anos permitiu o retorno de Gandhi ao poder. No entanto, o novo governo do CNI se diferenciou profundamente do primeiro mandato de Gandhi. A mandatária se afastou definitivamente do socialismo defendido por seu pai e deu início a uma abertura mais profunda da economia indiana.

Este processo não foi interrompido pelo assassinato de Indira Gandhi em 1984 devido a conflitos de seu governo com a minoria Sikh. Seu filho e sucessor, Rajiv Gandhi, segue e aprofunda os ideais liberalizantes iniciados no governo anterior. Desde então, o aprofundamento do modelo de desenvolvimento liberal capitalista irá marcar as políticas econômicas e sociais do país. (Kohli, 1987)

Three decades of planned economic development have failed to improve the living conditions of India's poor. This persistence of poverty is clearly manifest in the continuance of low percapita 
income. It is nevertheless clear by now that higher growth rates, and therefore higher percapita income, are not sufficient to improve the lot of the poor. New wealth has not "trickled down." The solutions to the problem of India's poverty will thus not emerge from higher rates of economic growth alone; if they emerge at all, they are likely to involve conscious state intervention aimed at reconciling growth with distribution. (Kohli, 1987:1)

A chegada do processo de liberalização, promove uma nova estratégia de desenvolvimento baseada no crescimento de mercados, redução do estado, o aumento dos fluxos de importação e exportação. No entanto, no campo social, esta mudança não altera o princípio do Trickle Down. A pobreza continuou aliviada por meio de programas de segurança alimentar enquanto a difusão da riqueza vinda do crescimento econômico não se realizasse.

Rajiv Ghandhi seguiu no poder até 1991 quando, assim como sua mãe, foi assassinado. A partir de então uma sucessão de governos de centro direita do BJP (Bharatiya Janata Party) radicalizaram o processo de liberalização da economia.

De acordo com Stein (2010), esse período testemunhou um rápido crescimento da economia indiana. No entanto, a riqueza advinda desse processo ficou restrita a elite urbana do país. Como afirma Chandrassekhar e Ghosh (2002):

\begin{abstract}
"The Marketist economic reforms of the 1990s were not explicitly directed at reducing poverty so much as increasing growth an 'efficiency'. Nevertheless, as we have seen in the previous chapter, it was expected that liberalizing markets, easing the conditions for entry and operation of foreign investors and encouraging exports especially in agriculture, would all contribute to more growth and employment generation, and consequentially lead to a decline I poverty through the 'trickle down' effect. However, the experience of the 1990s belied these expectations. (Chandrassekhar e Ghosh, 2002:157)
\end{abstract}

A liberalização, como denota o parágrafo acima, mais uma vez falhou como forma de combate a pobreza. Esse quadro propiciou, após 12 anos de governos neoliberais o retorno do Partido do Congresso Nacional Indiano ao poder. Com isso uma terceira abordagem ao desenvolvimento se inicia no país.

Em 2003 a United Progressive Aliance - UPA assume o governo do país iniciando a implementação de ações diretas focalizadas para a redução da pobreza. (Chandrassekhar e Ghosh, 2002). Enfim, o princípio do Tricle Down se enfraquece e, assim como admitiu o 
Banco Mundial no final da década de 1990, foi preciso revalorizar o papel do Estado no processo de desenvolvimento.

Os dois principais programas já implementados para enfrentar os problemas sociais no país pelo governo Manhoman Singh, foram o NRHM - National Rural Health Mission e o MGNREGA - Mahatma Gandhi National Rural Employment Guarantee Act, ambos iniciados em 2005.

O MGNREGA, é considerado um marco nas ações do Estado em termos da mudança paradigmática ocorrida no país para o trato das questões sociais. Pela lógica desta iniciativa, foi reconhecido o direito ao trabalho dos que vivem no campo e o governo se propõem a garantir um número mínimo de 100 dias de labuta trabalhadores rurais.(MRD, 2014)

Os que vivem no campo e se encontram abaixo da linha nacional de pobreza podem requerer trabalhos para o governo e são remunerados por tal. Alguns autores, como Kapur (2011) afirmam, como podemos notar na citação abaixo, que este programa se trata, em última análise, de uma TDCR.

Indeed, while its proponents may not like the designation, India's flagship National Rural Employment Guarantee Scheme is at heart a conditional CT programme. (Kapur,2011:68)

Tal visão, no entanto, está longe de ser consensual. Uma vez que se trata de uma garantia de direitos. Ou seja, ao contrário do Bolsa Família e do Oportunidades, a inclusão do programa e o acesso ao benefício não pode ser limitada ou negada. Além disso, o trabalho não é uma condicionalidade nos moldes latino-americanos, ou seja, não procura aumentar o capital humano das famílias e nem proporciona a quebra de ciclos geracionais de pobreza.

A visão de Kapur, no entanto, não é consensual. Autores como Kotwall (Kotwall et all, 2011) afirmam que existem profundas diferenças entre as TDCRs e o MGNREGA. Isso pois o cada um se inclui em movimentos diferentes e paralelos que se encontram em curso no país. Segundo eles, por um lado existe um esforço, voltado a implementação de direitos 
básicos, capitaneado pelo National Advisory Concil - NAC ${ }^{42}$. Este movimento inclui, além do MGNREGA, a busca pela efetuação do direito a informação e educação:

It was conceived by the National Advisory Council (NAC), where much of the progressive legislation of recent times such as the Mahatma Gandhi National Rural Employment Guarantee Act (MGNREGA), Right to Information, Right to Education has been conceived. (Kotwall et all, 2011)

Em paralelo a este processo o governo também procura implementar as transferências diretas de renda como forma de combate a pobreza que, em última análise, visa a substituição do PDS e dos subsídios agrícolas. Nos dedicaremos em detalhe a esse segundo movimento em parte específica abaixo.

O National Health Mission, por sua vez, congrega um conjunto de medidas para estabelecer uma rede de atendimento de saúde no interior do país. O programa prevê, entre outras coisas, a instalação de clinicas, treinamento de profissionais de saúde e melhorias em hospitais. (Standing, 2011)

Com isso, encerramos o sobrevoo proposto sobre as estratégias de desenvolvimento estabelecidas pelo governo central indiano desde a independência. Assim como na história do Banco Mundial e das políticas sociais no Brasil trata-se de uma trajetória que incorpora pauliatinamente programas voltados ao desenvolvimento social.

\footnotetext{
${ }^{42}$ O National Advisory Committee é um órgão colegiado consultivo criado em 2004 para assessorar o primeiro ministro e foi coordenado ao longo de quase todo o governo por Sonia Gandhi
} 


\section{As políticas sociais do Governo Nacional Indiano: da segurança alimentar as transferências de renda.}

Como já começamos a descrever acima, os governos pós-independência focaram os esforços sociais para a garantia da segurança alimentar da população. Ao poucos, no entanto, a relação entre fome e pobreza passa a perder força. Duas evidências deste movimento serão apresentadas aqui. A primeira é a alteração do cálculo base da linha nacional de pobreza que fundamenta o acesso a maioria das políticas sociais no país.

A segunda evidência é a adoção das TDRs, que parecem ser a política de preferencia para substituir tanto o PDS quanto os subsídios a produtos e produção agrícola.

\section{A linha nacional de Pobreza na Índia}

Para uma nação de 1.2 bilhão de habitantes, a segurança alimentar assume imediatamente status de tema estratégico. Desde o período colonial, esta questão é causa de instabilidades e transformações na sociedade indiana.

A fome e a subnutrição foram problemas recorrentes na história do país. Patnaik (Patnaik e Moyo, 2011) afirma, o aumento da escassez de alimentos e consequentemente da fome ocorreu no período colonial. Durante o domínio inglês, ao mesmo tempo em que a novas técnicas de agricultura promoviam o aumento da produção, foram impostas cotas obrigatórias de exportações à Inglaterra. A relação desigual entre esses territórios está na gênese tanto da segurança alimentar inglesa quanto da fome na Índia. (Patnaik e Moyo, 2011)

A independência não diminuiu a importância tema que, desde então, passou a ser enfrentado por um governo nacional voltado a promoção do desenvolvimento do país e não da metrópole. Como já descrevemos acima, o tema da pobreza só passou a ser tratado de maneira mais direta no governo de Indira Gandhi. Portanto, foi apenas em 1970 que a pobreza recebeu uma definição e medida oficial. Neste momento foi oficializada a linha Dandekar-Rath $^{43}$, nomes dos economistas que a formulam. Por este método foi

${ }^{43}$ Dandekar and Rath, "Poverty in India." 
estabelecido que indivíduos que consumiam uma quantidade inferior a 2250 calorias/dia na região rural e a 2100 calorias/dia nas áreas urbanas deveriam ser considerados pobres. (Patnaik, 2006).

It was suggested in Dandekar and Rath's pioneering 1971 paper and was taken up by the Planning Commission in India, which set up in 1979 a Task Force on Projection of Minimum Needs and Effective Consumption Demand. Its recommendation which was accepted, was based in turn on the Indian Council of Medical Research table of dietary intakes (see Gopalan 1992, 1997) which was applied to the population structure by age and gender. On average 2400 and 2100 calories per day per capita worked out as the required daily allowance (RDA) for energy intake, for rural and urban areas respectively, and all persons unable to access this through their actually observed expenditure were to be considered as poor. (Patnaik, 2006:S/N)

Por este cálculo a fome era estabelecida como o principal indicativo mensurável da pobreza. Trata-se de uma definição que denota uma visão sobre pobreza que não se limita a renda individual. Esta linha abre portas, por exemplo, para considerar indivíduos com ganhos menores e mais acesso a alimento se posicionarem do critério definidor da pobreza. Da mesma forma, pessoas renda maior, dependendo das condição e características do local em que vivem, podem se encontrar abaixo da linha nacional de pobreza.

Patnaik argumenta, apesar do caráter reducionista, esta linha se constitui como o princípio da relação estável que o Estado indiano estabelece entre fome e pobreza. (Patnaik, 2003) Como afirma a autora:

"In a poor developing country, the incidence of poverty is very closely linked to the availability of food, in which the staple food grains still remain predominant, accounting for three fifths of the daily energy intake of the population.”(Patnaik 2003:152)

Duas críticas são recorrentes a formula Dandekar-Rath. A primeira decorre da não inclusão de outros indicativos da condição de pobreza, como acesso precário a serviços de saúde e baixos índices de escolaridade. A segunda, por ser uma medida de pobreza absoluta, pouco permeável às variações de cada território (Patnaik, 2006).

Subscrevemos a primeira parte do argumento da autora, que, em ultima análise defende uma concepção multicausal da pobreza. O segundo, no entanto, se mostra menos claro, uma vez que a determinação de um mínimo calórico foi estabelecida a partir de critérios médicos que desconsideravam condições ambientais e de trabalho. 
No entanto, ao menos em termos de sua unidimensionalidade o critério de Dandekar-Rath é equivalente a de US\$1 ao dia utilizado pelas agência multilaterais. A esta medida podese aplicar mais facilmente a segunda crítica de Patnaik a linha Dandekar-Raft. Um dólar ao dia representa diferentes capacidades de compra de acordo com a realidade econômica local. Portanto, padroniza de maneira mais arbitrária as diversas faces da pobreza.

Um critério linear, como já discutido no capítulo sobre o Bolsa Família, facilita o desenho e execução de políticas públicas. Ghosh nota que definições multidimensionais, preferidas no campo acadêmico, são de difícil operacionalização. Motivo pelo qual, os indicadores simplificados seguem em utilização apesar de suas imperfeições:

"However broad definitions of poverty have their own difficulties.
While it is certainly important to grasp a multidimensional nature
of the problem and to remember that policy measures therefor have
to be a multi-pronged, it is also true that one-dimensional measures
hava a power and a relative ease of measurement that cannot be
achieved in broader measures."(Ghosh, 2002)

As críticas a linha Dundekar-Rath resultaram na criação pela Indian Planing Comission de uma força tarefa para rever a metodologia de cálculo da linha de pobreza nacional. No ano de 1979 foi instalada a 'Projections of Minimum Needs and Effective Consumption Demand Task Force', coordenada pelo economista e futuro Ministro de Estado Yoginder K. Alagh. (IPC, 2012):

The Task Force (reported in 1979) defined the poverty line as monthly per capita consumption expenditure (MPCE) level of Rs.49.09 for rural areas and Rs.56.64 for urban areas at 1973-74 prices at national level. These corresponded to the money value of a basket of goods and services that would cover per capita daily calorie requirement of $2400 \mathrm{kcal}$ in rural areas and $2100 \mathrm{kcal}$ in urban areas, along with other non-food items such as clothing, footwear, education, health and transport, etc. in observed quantities in the basket corresponding to the recommended level of calories. (IPC, 2011)

As recomendações da comissão foram adotadas pela IPC que mudou pela primeira vez o cálculo da linha nacional de pobreza. Desde então, a fórmula passou a ter como base o preço de um conjunto de produtos e serviços. A linha da pobreza, embora monetarizada, permaneceu atrelada ao princípio do consumo calórico. Isso pois, o critério para a composição da cesta de produtos e serviços, foi o mínimo necessário para atingir o consumo mínimo determinado por Dandekar-Rath. (IPC, 2011) 
Esta nova linha de pobreza apresenta a vantagem de possibilitar uma coleta mais fácil e precisa de dados. Se antes era preciso relatar o consumo calórico dos indianos, desde então bastava acompanhar os preços dos produtos. Por outro lado, mais uma vez, por ser uma linha nacional, releva as diferenças regionais.

Uma segunda revisão só ocorreu em 1993. Neste momento, coincidente a chegada das políticas de ajuste estrutural no país a linha de pobreza doi alterada de maneira a dar espaço as diferenças internas da Índia. O novo método, manteve mais uma vez como base o consumo calórico e a cesta de produtos e serviços. A fome segue como principal indicador de pobreza para o governo nacional.

A mudança foi proposta pelo Expert Group on 'Estimation of Proportion and Number of Poor' ou, simplesmente Lakdawala Comitee (LC), comandado por D.T. Lakdawala (IPC, 2011), economista e professor da Universidade de Mumbai. O relatório final recomendou a regionalização e o cálculo em preços correntes. (IPC, 2011)

As fórmulas anteriores, estabeleciam duas linhas de pobreza, uma rural e outra urbana, definidas pelas diferentes necessidades calóricas de cada realidade. A LC manteve esta divisão, no entanto, ao propor a regionalização multiplica as linhas oficiais de pobreza pelo número de estados do país. Em última análise, trata-se da substituição de uma medida absoluta por uma relativa de pobreza.

Em 2005, após a chegada do UPA ao poder, foram impostas novas alterações ao cálculo da linha nacional de pobreza. A transformação foi profunda e de caráter conceitual, pois, naquele momento, a IPC dissocia pela primeira vez o cálculo da pobreza da fome. A mudança foi fruto de um comitê conduzido pelo Prof. Suresh D. Tendulkar, economista, doutor pela universidade de Harvard e, até então, diretor da comissão nacional de estatística.

As recomendações propostas pelo comitê, evidenciam uma aproximação com padrão utilizados pelo Banco Mundial e um rompimento completo com os cálculos anteriores:

Tendulkar Committee's approach made four major departures, which, in their view constituted significant improvements over the existing official poverty estimation procedure; i) consciously moving away from calorie anchor; ii) recommending to provide a uniform 'poverty line basket' (PLB) to both the rural and urban population; iii) recommending a price adjustment procedure that is predominantly based in the same data set that underlies the poverty estimation, and iv) incorporating an explicit provision in price 
indices for private expenditure on health and education. (IPC, 2011)

Duas das recomendações citadas acima indicam a incorporação da percepção de pobreza do Banco Mundial: a) o afastamento da relação entre pobreza e o consumo de calorias e, portanto, da fome e b) o fim de leituras separadas para a pobreza rural e urbana.

Se estes dois aspectos aproximam a linha de pobreza adotada pela Índia dos modelos generalizantes dos organismos internacionais, a nova cesta de produtos e serviços passa a incorporar gastos com educação e saúde. Além disso, trata-se de uma medida relativa, atualizada para valores correntes do ano de 2003. No entanto, a recomendação de utilizar a mesma linha para toda a nação retoma um aspecto absoluto que compunha o cálculo antes de 1993. A citação abaixo, exemplifica a nova linha de pobreza adotada na Índia:

In 2011, until September, the Planning Commission continued to keep Rs 20 as the cut-off for defining poverty, which even more artificially represented the extent of poverty, as there had been extensive consumer inflation in the past decade. Then the Planning Commission filed an affidavit in the Supreme Court settling the cut-off at Rs 32 in urban areas and Rs 26 in rural areas. (Standing, 2012)

A nova medida de pobreza será instrumental para a adoção dos programas de TDCR da Índia e para a requisição de direitos garantidos pela legislação - como o caso do MGNREGA. A metodologia proposta foi intensamente criticada pela sociedade civil ${ }^{44}$ uma vez que pelos critérios adotados a porcentagem da população vivendo abaixo da linha da pobreza diminuiu.

Tabela 10 - Porcentagem da população indiana vivendo baixo da linha da miséria

\begin{tabular}{|l|l|l|l|}
\hline Ano & Rural & Urbano & Total \\
\hline $1993-94$ & 50.1 & 31.8 & 45.3 \\
\hline $2004-05$ & 41.8 & 25.7 & 37.2 \\
\hline $2009-10$ & 33.8 & 20.9 & 29.8 \\
\hline $2011-12$ & 25.7 & 13.7 & 21.9 \\
\hline
\end{tabular}

${ }^{44}$ Um exemplo é a Right to Food campaign que agrega grande parte dos movimentos contrários a implementação de transferências diretas de renda no país 
Fonte: Planning Commission;

Esta mudança mascarou, de acordo com os críticos da nova metodologia, a verdadeira dimensão da pobreza no país. Isso pois, foi o calculo, e não a vida dos indianos, a causa dessa queda. A adoção dos critérios da Tendulkar Comission serviu tanto a propaganda governamental quanto a diminuição dos atendidos pelos programas sociais no país.

Em síntese, o processo acima descrito, demonstra uma das facetas do novo modelo de proteção social adotado no país desde 2003. Neste momento de transformação, foi adotada uma definição monetarizada de pobreza, baseada em uma cesta de consumo. Além disso, essa medida é imposta de maneira geral a todas as regiões do país.

\section{As Transferências Diretas de Renda na Índia, pode-se enxergar uma direção?}

De acordo com o que foi descrito acima tanto as ações do Governo Indiano contra a pobreza quanto a mensuração deste fenômeno estiveram historicamente conectadas a segurança alimentar. Se no tópico anterior nos dedicamos a mudança conceitual, este será voltado as transformações nas políticas de combate a pobreza.

Desde a independência as principais políticas sociais do estado indiano se resumem a duas ações interligadas e voltadas a segurança alimentar: a) O sistema de subsídios a alimentos e produção agrícola e o b) Sistema Público de distribuição - PDS. (Kohli, 1987)

Como afirma Ghosh, as raízes deste modelo podem ser identificados na década anterior a segunda grande guerra, portanto antes mesmo da independência e, Embora sobre grande pressão, perduram os dias atuais. (Ghosh, 2013)

Os subsídios do governo indiano incidem sobre três áreas: a) fertilizantes, b) alimentos e c) derivados de petróleo. (DEA, 2004) Todos atingem, de maneira direta ou indireta, a produção agrícola e representam uma das maiores parcelas do orçamento do governo indiano na área social. O quadro abaixo mostra o valor gasto em subsídios a entre $1991 \mathrm{e}$ 2011. 
Tabela 11 - Subsídios na Índia ${ }^{45}$

Table 1: Major Subsidies (in crores of Rupees) in India: 1990-91 to 2012-13

\begin{tabular}{|l|c|c|c|c|}
\hline Year & Food & $\begin{array}{l}\text { Percentage } \\
\text { Change over } \\
\text { Previous Year }\end{array}$ & $\begin{array}{c}\text { Percentage of } \\
\text { GDP from } \\
\text { Agriculture }\end{array}$ & $\begin{array}{c}\text { Percentage of } \\
\text { Total } \\
\text { Subsidies }\end{array}$ \\
\hline $1991-92$ & 2850 & - & 1.8 & 23.3 \\
\hline $1992-93$ & 2800 & -1.8 & 1.5 & 23.3 \\
\hline $1993-94$ & 5537 & 97.8 & 2.6 & 47.7 \\
\hline $1994-95$ & 5100 & -7.9 & 2.1 & 43.0 \\
\hline $1995-96$ & 5377 & 5.4 & 2.0 & 42.5 \\
\hline $1996-97$ & 6066 & 12.8 & 1.9 & 39.1 \\
\hline $1997-98$ & 7900 & 30.2 & 2.4 & 42.6 \\
\hline $1998-99$ & 9100 & 15.2 & 2.4 & 38.6 \\
\hline $1999-00$ & 9434 & 3.7 & 2.3 & 38.5 \\
\hline $2000-01$ & 12060 & 27.8 & 2.9 & 44.9 \\
\hline $2001-02$ & 17499 & 45.1 & 4.0 & 56.1 \\
\hline $2002-03$ & 24176 & 38.2 & 5.7 & 55.5 \\
\hline $2003-04$ & 25181 & 4.2 & 5.2 & 56.8 \\
\hline $2004-05$ & 25798 & 2.5 & 5.3 & 56.1 \\
\hline $2005-06$ & 23077 & -10.5 & 4.3 & 48.6 \\
\hline $2006-07$ & 24014 & 4.1 & 4.0 & 42.0 \\
\hline $2007-08$ & 31328 & 30.5 & 4.4 & 44.2 \\
\hline $2008-09$ & 43751 & 39.7 & 5.4 & 33.7 \\
\hline $2009-10$ & 58443 & 33.6 & 6.3 & 41.3 \\
\hline $2010-11$ & 63844 & 9.2 & 5.8 & 36.8 \\
\hline $2011-12$ (RE) & 72823 & 14.1 & - & 33.7 \\
\hline $2012-13$ (BE) & 75000 & 3.0 & - & 39.5 \\
\hline Sources: Government of India (2012) & & & & \\
\hline
\end{tabular}

Os dados acima evidenciam que, ao longo da história recente do país, os gastos com subsídios foram crescentes. Esta evolução não se detém mesmo diante do processo de liberalização e, apesar do contexto ideológico favorável a redução dos gastos e equilíbrio fiscal dos anos 1990, os valores destinados a esta rubrica apresenta aumentos notáveis.

In the mid-1960s, a coherent set of policies were introduced to address the problem of food insecurity, policies dealing with production, storage and distribution. These policies did have some success, especially in respect of accelerating the production of food grain and in respect of ensuring a period of low and stable prices for cereals. In the period of economic liberalization, starting in 1991, policies to address food security have been weakened, and have had a very damaging impact on consumption and nutrition. Today, given the high rate of inflation, the situation is even more critical. (Swaminathan, 2008:2)

\footnotetext{
${ }^{45}$ World Bank India report 2013, pagina 4.
} 
A variação demonstrada na tabela é influenciada por múltiplos fatores: o aumento dos custos de produção, flutuações de preços no mercado internacional, condições climáticas entre outros. No entanto, como indica a citação acima, a redução dos recursos destinados aos demais programas e ações sociais do governo em nome da responsabilidade fiscal, exigiram um incremento nos subsídios para evitar a fome.

Este quadro aparentemente incoerente de liberalização com aumento de subsídios, demonstra que, mesmo neste período, a fome segue como tema inevitável para a sociedade indiana. Atualmente, o gasto com subsídios está próximo de $6 \%$ do PIB do país e, portanto, está no centro da agenda de corte de gastos do governo.

The public distribution system or PDS is a rationing mechanism that entitles households to specified quantities of selected commodities at subsidized prices. In most parts of the country, up to 1997, the PDS was universal and all households, rural and urban, with a registered residential address were entitled to rations. (Swaminathan, 2008:2)

O PDS (Public Distribution System), por sua vez, foi inaugurado em 1939 com o objetivo de racionalizar a distribuição de alimentos em tempos de guerra. Durante a década de 1970 diante da acentuação do problema da fome o PDS será transformado em um direito universal. Consolidando-se assim como uma das principais políticas de alívio à pobreza. Como afirma Swaminathan:

The drought and food shortages of the mid-sixties highlighted the need for strengthening and continuing with a system of food distribution and the PDS was made a universal scheme in the 1970s. Thus, from its inception as a rationing scheme in big cities during World War II, the PDS was converted into a universal programme for the provision of cheap food and made a component of the strategy to alleviate poverty. (Swaminathan, 2008:2)

Segundo Swarmitan, historicamente o PDS agrega os seguintes objetivos:

- Manutenção da estabilidade de preços

- Garantia de maior bem estar as populações de baixa renda,

- Racionalização da distribuição de alimentos em momento de crise

- Manter baixos os preços do mercado privado .

(Swaminathan, 2008:3) 
Este programa funcionou, desde a universalização promovida no governo de Indira Gandhi, como direito estendido a todos os indianos. Além disso, assim como o projeto do Fome Zero no Brasil, procura regular o modelo excludente do mercado e procura manter a estabilidade de preços.

No entanto, como a maioria das garantias universais promovidas pelos Estados periféricos, a distância entre intenções e gestos é enorme. A eficiência do sistema é constantemente atacada. As principais criticas são: corrupção, falta de produtos, a baixa qualidade dos alimentos e a ineficiência da fiscalização. (Kapur, 2011)

Estas criticas, somadas ao alto custo do sistema se constituíram como os principais argumentos para determinar o fim da universalidade do mesmo nos anos 1990. Por trás desse discurso se encontra a necessidade imposição de ajustes estruturais e determinado pelo Banco Mundial:

Targeting. The most distinctive feature of the TPDS in relation to previous policy in India is the introduction of targeting, specifically, the division of the entire population into belowpoverty- line (BPL) and above-poverty-line (APL) categories, based on the poverty line defined by the Planning Commission. The two groups are treated differently in terms of quantities and prices. With this, the Government of India initiated a policy of narrow targeting to households with incomes below the official poverty line.

Dual (multiple) prices. The second distinguishing feature is that the PDS now has dual central issue prices: prices for BPL consumers and prices for APL consumers. A third price, introduced in 2001, is for beneficiaries of the Antyodaya Scheme (a scheme for the 'poorest of the poor', in which food grain is distributed with an additional subsidy). In March 2000, a major policy change occurred when it was announced in the budget that central issue prices - that is, prices at which the Food Corporation of India (FCI) sells grain for the PDS to State governments-will be set at half the 'economic cost' incurred by the FCI for BPL households and at the full 'economic cost' for APL households.5 In short, there was to be no subsidy for APL households.

Centre-state control. A third important feature of the Targeted PDS is that it has changed centre-state responsibilities with respect to entitlements and allocations to the PDS. PDS is designed and managed by State governments, and state governments differ with respect to entitlements, the commodities offered, the retail price (state issue price) and so on. In the past, the State governments demanded a certain allocation from the central pool, and based on 
certain factors, most importantly, past utilization and the requirements of statutory rationing, the central government allocated grain and other commodities to States for their public distribution systems. With the TPDS, the size of the BPL population and the entitlements for the BPL population are decided by the central government. And the allocations for APL populations or additional allocations for BPL and APL populations are decided somewhat arbitrarily based on past utilization and demands from States. (Swaminathan, 2008:3e4)

A introdução da linha de pobreza como critério para a diferenciação de preços e quantidades, afasta o PDS da do caráter universal anterior. Embora, estas mudanças ainda não configurarem um distanciamento total, marcam o início de um caminho de transformações.

As duas principais ações de proteção social por meio da promoção da segurança alimentar na Índia são os principais alvos da nova estratégia do governo da UPA. A proposta é substituir aos poucos este modelo por TDRs. 


\section{Os programas de transferência de renda na Índia}

As experiências de transferência de renda na Índia não podem ser resumidas a uma ou duas iniciativas. Existem projetos piloto tanto de âmbito nacional quanto regional, voltados a diversos temas e objetivos. A implementação destas estratégias se encontra em estagio inicial e, portanto, o quadro que será apresentado abaixo é um retrato incompleto. O material de pesquisa utilizado para construir este quadro está restrito muitas vezes a intensões do governo expressas em documentos oficiais e as primeiras avaliações das experiências piloto em andamento.

Mesmo em estágio inicial de implementação, movimento de transformação do modelo de proteção social adotado no país já suscita um intenso e fervoroso debate. Este segmento está dividido em duas partes: a) o debate sobre o modelo de TDR a ser implementado e b) a discrição dos principais programas piloto.

\section{O debate atual}

Recent months have witnessed a spur in discussions on cash transfers as an instrument for delivering social security in India. (Narayanan, 2011)

Como afirma Narayanan (2011), a guinada do governo indiano em direção ao um modelo de proteção social em que as TDR assumem um papel central. Parte desta pesquisa foi dedicada a mapear as principais posições nesta discussão pública.

Quatro perspectivas divergentes foram identificadas a longo da desta parte da investigação. Estas posições não esgotam todas as posturas e discordâncias sobre a adoção das TDRs no país, mas pretendem apresentar um quadro geral dos tipos de abordagem que este assunto tem recebido. 
a) A ineficiência do modelo atual como justificativa para a adoção do novo paradigma de proteção social.

O primeiro posicionamento encontrado, prega o abandono das estratégias tradicionais e a substituição pelas Transferências Diretas de Renda e motivado pela desilusão com a ineficiência do sistema de subsídios e com o PDS. Como afirma Standing (2012), citando fala do então presidente da Indian Planning Comission, apenas uma parcela mínima dos alimentos subsidiados alcança as camadas mais pobres do país:

The government and the World Bank admit that 59 per cent of the grain allotted to public distribution for the poor does not reach low-income households. The Deputy Chairman of the Planning Commission, Montek Singh Ahluwalia, said in 2009 that in his view only 16 per cent of the food allocated to the PDS reached the poor. At about the same time, the Planning Commission estimated that only 27 per cent of PDS expenditure reached low-income groups, and the Finance Minister described it as 'an albatross around our neck and an opportunity for rent seekers to enrich themselves'. (Standing, 2012:29)

A percepção da ineficiência do atual sistema se soma também a necessidade de corte de gastos e o combate a corrupção. Esta é a posição defendida por membros do governo indiano (Standing, 2012) e pelos organismos internacionais (WB, 2012). O discurso oficial prevê apenas uma substituição parcial do antigo modelo (Kotwall et all, 2011). No entanto, de acordo com as entrevista ${ }^{46}$ realizadas ao longo deste trabalho, uma possível redução de custos advindas da adoção das TDRs levaria inevitavelmente a uma troca completa.

b) A adoção das TDRs na Índia deve ser vista com desconfiança pois trata-se de mais um capítulo da difusão do neoliberalismo no país.

Um segundo grupo identifica as TDCRs como sequencia do processo de liberalização iniciada nos anos 1990 e, portanto, se configura como apenas mais um método regressivo de ação social. Segundo esta perspectiva, o projeto neoliberal continua seu avanço sobre os 
serviços públicos básicos em busca de um estado gerencial mínimo. Os Subsídios e o PDS são apenas as mais novas vítimas deste processo.

However, the current tendency is to see this as a further excuse for the reduction of publicly provided services, and replace them with the administratively easier option of doling out money. (Ghosh, 2011:63)

Esta posição de intelectuais críticos e marxistas como Jayati Ghosh e ONGs voltadas a promoção da segurança alimentar procura evidenciar a inspiração ideológica neoliberal destas políticas e a implementação em um processo amplo de transformação do papel do Estado.

De fato a adoção de um modelo de proteção social com base em TDRs possui, como já apresentamos acima, vinculação com o processo de transformações e ajustes estruturais da década de 1980. A composição de redes de seguranças nacionais e a posterior evolução para as chamadas springbords (ver capítulo 4) em que as TDRCs passam a compor a agenda do Banco Mundial confirmam a conexão evidenciada por autores como Ghosh. A autora, no entanto, admite a possibilidade da adoção de TDRs comum novo adendo a ao atual sistema de proteção, e não um substituto:

So the question then is not whether or not to oppose cash transfers in general, but rather what specific importance to give them in an overall strategy of development and poverty reduction. Cash transfers cannot and should not replace the public provision of essential goods and services, but rather supplement them. In other words, cash transfers are desirable and can play a positive redistributive role if they are additional to other - and essential public expenditure on essential goods and services that are required by all citizens, including the poor. (Ghosh, 2011:68)

Esta posição é também defendida por oganizações da sociedade civil que atuam na promoção e defesa das políticas de segurança alimentar unidas na Right to Food Campaign , uma das maiores entidades deste campo. ${ }^{47}$ Em manifesto das entidades que participam desta campanha é dita:

\footnotetext{
47 falar mais dessa e de outras http://infochangeindia.org/agriculture/analysis/the-case-against-cashtransfers.html e citada pela oxfam como uma das mais importântes pressões aos congressitas indiano http://oxfamblogs.org/fp2p/unpacking-indias-historic-new-food-security-law/
} 
The Right to Food Campaign strongly feels that the Public Distribution System (PDS) must not be dismantled, as it plays an important role in not only improving people's access to food but also revitalising agriculture and promoting food production. Repeated studies are showing that the Indian growth experience is lopsided, benefitting only a few while the majority of the population continues to face poverty and deprivation. (Right to Food Collective Statement, 2008)

E segue:

The system of cash transfers must be seen as part of the larger trend towards privatisation, where the government is slowly washing its hands away from its responsibility of providing basic services and social security to its citizens. We are witnessing such privatisation in different sectors including basic education, health care and now food. Such a move takes the power away from people to demand accountability and better service delivery systems for themselves. (Right for Food Manifesto. (Right to Food Collective Statement, 2008)

c) As TDRs devem ser adotadas como um direito universal a ser estendido a todos os cidadãos indianos de baixa renda.

No terceiro posicionamento identificado, a adoção de transferências de renda só seria possivel em forma de direito amplo e universal. Autores como Kotwal et al (2011) compartilham de uma posição crítica a respeito do sistema de subsídios e PDS:

When good policy goals are frittered away through wasteful government schemes, it gives fodder to those who had little sympathy with such goals in the first place. The National Food Security Bill is a worthy goal. However, it will do little for the poor if the government insists on implementing it only through the deeply flawed public distribution system (PDS). We will make a case here that the proposed alternatives to PDS such as food coupons and smart cards (effectively cash transfers) are viable in the Indian context and will be much more effective in the long run from the point of view of the poor. (Kotwal et Al, 2011:72)

Tal abordagem é minoritária no debate sobre o tema na Índia e, em última análise, propõem modelo de garantias de renda mínimas já discutidas em outro momento deste texto. 
identifying the poor in a country like India is a formidable task for all the reasons mentioned earlier. Only universal coverage can solve it, and this is why we favour it. (Kotwal et Al, 2011:63)

d) As Transferências de Renda devem fazer parte, mas não substituir o sistema em vigor.

A defesa da implementação de transferências de renda como um componente de um plano maior de desenvolvimento social é discurso oficial do Governo da United Progressive Aliance. O trecho abaixo extraído do documento da Task Force for Direct Transfer of Subsidies $^{48}$ estabelecido pelo governo central indiano propõem um sistema em que o beneficiário poder optar pela compra do produto subsidiado ou pela transferência direta:

Where possible, it is best to empower beneficiaries and give them the choice to receive subsidies in the form of subsidized goods and services or as cash, based on their own preferences. Further, beneficiaries should also be offered choice to exercise their preference at any participating location, rather than restricting the service delivery point to a specific location. (TFDTS, 2011:1)

Como já foi descrito acima, o caráter meramente estratégico desta posição conciliatória é denunciada pelos movimentos sociais.

\section{O programas piloto de TDR na Índia}

Em 2003, o Primeiro Ministro Manmohan Singh instalou uma comissão na IPC para avaliar a adoção de políticas de transferência de renda. Em seu documento inicial, os programas do Brasil e México são citados como modelo. Segue trecho do documento da primeira reunião da comissão:

C. Experience with Cash Transfers in Other Countries

Cash Transfers, both unconditional and conditional, are now used by many countries across the world (29 in 2008). Some of the cash

\footnotetext{
${ }^{48}$ Unique Identification Authority of India (UIDAI) chairman Nandan Nilekani.
} 
transfer programs are huge in size, particularly in Latin American countries:

Brazil's Bolsa Familia covers $25 \%$ of the population with 11 million households and 46 million people and costs $0.5 \%$ of GDP. Brazil has also used the program to reform and merge many other cash transfers such as a cash transfers for pregnant/ lactating women, cooking gas subsidies and food assistance.

Mexico's Opportunidades covers $25 \%$ of the population with 5 million households and provides transfers which are $\sim 20 \%$ of household consumption. This replaced inefficient subsidies and poorly targeted cash transfers and gave beneficiaries the freedom to choose how they used the transfers as long as they committed to certain behaviors.

Similar programs are operating In Asia, and the developed world as well, including in New York City and Washington DC. (IPC, 2012)

O documento resultante dos trabalhos do grupo recomenda a implementação de programas piloto de transferência de renda. Estas iniciativas, ainda de acordo com o mesmo documento, devem servir como base para avaliar a possibilidade ampliar a adoção deste sistema.

Selecionamos os três principais programas piloto de TDR em funcionamento. Procuramos identificar nestas experiências, três aspectos: a) as características das políticas em adoção no país, b) Qual o sentido das mudanças no sistema de proteção social em curso na Índia e c) sinais incorporação de elementos do modelo latino americano.

\section{Janani Surakasha Yojana}

O Primeiro é o Janani Surakasha Yojana - JSY ${ }^{49}$. Trata-se de uma politica voltada a saúde da mulher e que procura prevenir mortes durante partos estimulando que gravidas de baixa renda procurem centros médicos credenciados. Na Índia, entre as famílias pobres, prevalecem os partos caseiros e sem acompanhamento de um profissional de saúde.

\footnotetext{
${ }^{49}$ Os resultados e descrição deste programa é baseada em relatório India's JSY cash transfer program for maternal health: Who participates and who doesn't - a report from Ujjain district
} 
Women delivering in non-high focus provinces (provinces with a relatively better in-facility birth proportion) are only eligible for the cash benefit for their first two live births, and if they have a government issued below the poverty line card or belong to a scheduled caste or tribe. (Sidney et Al, 2012:5)

De acordo com as normas e regras do programa as mulheres grávidas recebem transferência direta em dinheiro para a realização de partos em instituições de saúde credenciadas pelo governo.

O JSY tem regras de focalização diferentes para províncias classificadas com high-focus e non high-focus. (Sidney at Al, 2012)

a) High-focus Provinces: Neste caso, todas as mulheres cujas famílias se encontram abaixo da linha nacional de pobreza podem participar do programa e não ha restrições ao número de partos para o recebomento do benefício.

b) Non High-focus Provinces: Assim como no caso anterior, só podem participar do programa mulheres que se encontram abaixo da linha nacional de pobreza ou originárias de alguma casta ou tribo pré-inscrita no programa. No entanto, o recebimento do benefício é limitado a dois partos por mulher.

O intuito é diminuir a mortalidade das mães e crianças na Índia, considerado extremamente alto para os padrões internacionais ${ }^{50}$. Em 2010, 19\% de todas as mortes maternas ocorridas durante o parto no mundo foram registradas na Índia.

Trata-se de uma política de alto grau de focalização. As benficiárias se restringem mulheres de zonas rurais, comprovadamente abaixo da linha de pobreza nacional e procura influir em um problema de grande especificidade. Neste aspecto, o JSY se assemelha aos programas focalizados de TDCR que antecederam o Bolsa Família no Brasil.

O JSY não tem como objetivo reduzir a pobreza, mas, por incorporar condicionalidades pode, em tese, ter proximidade com o modelo de TDCR latino americano. No entanto, as contrapartidas exigidas não tem a intenção de promover o desenvolvimento de capital humano e, portanto, não visam transformações de longo prazo na vida das famílias de baixa renda.

A number of national surveys and provincial data sources have demonstrated a steep increase in institutional deliveries both

\footnotetext{
${ }^{50}$ De acordo com o Banco Mundial a taxa de mortalidade materna em 2012 foi de 190 a cada 100.000.
} 
nationally and in Madhya Pradesh since the inception of the JSY program (figure 2) $[15,19,25-28]$. Lim et al. reported from an analysis of secondary data that the JSY program resulted in a $43.5 \%$ increase of institutional deliveries [7]. They reported a high uptake of JSY in Mad-hya Pradesh (44\%). In our study, $89 \%$ of the women had an institutional delivery. While more women are giving birth in facilities, what remains unknown is if the increase in institutional deliveries has occurred among the most vulnerable groups. ( Sidney et Ali, 2012: p5)

O programa tem apresentado índices significativos de sucesso. O número de partos institucionais aumentou 43,5\%, o que proporcionou a queda na mortalidade materna. (Sidney et al, 2012)

De acordo com o relatório Sidney et Al, (2012), o principal problema enfrentado pelo programa é a divulgação da existência do benefício entre so grupos mais pobres e isolados da nação. Este último fator leva o autor a questionar se de fato a estratégia alcança as mulheres em situação de maior vulnerabilidade.

Assim como o ApniBeti Apna Dhan (Ver capítulo 2) este programa se enquadra na categoria das transferencias condicionais de renda, no entanto, não está baseado no modelo latino americano. Isso, principalmente por dois motivos: a) Não, se destina diretamente ao combate a pobreza e b) as condicionalidades exigidas não visam a quebra de ciclos geracionais por meio de investimentos em capital humano.

\section{Programa de substituição dos subsídios de derivados de petróleo por transferências de} renda.

A segunda experiência, iniciada no final de 2012, substituiu subsídios de alguns derivados de petróleo por transferências diretas. Nos programas teste foram eliminados os subsídios ao gás de cozinha, querosene e fertilizantes. Como os programas pilotos ainda se encontram em andamento, não existem avaliações finais sobre os efeitos de sua adoção.

Among the Indian states, Bihar and Delhi are also considering replacing subsidies on PDS kerosene and domestic LPG with cash transfers. Two cash transfer pilot projects have recently been initiated in the country, one at Alwar in Rajasthan and the other at Mysore in Karnataka. The project in Alwar involves cash transfers 
for consumers of PDS kerosene, while the Mysore project is

looking to implement the same for LPG users. (Kapur, 2011:80)

Os programas piloto foram implementados em Alwar, no Rajastão onde o querosene subsidiado, encontrado nas lojas do PDS, foi substituído por transferências diretas. Em Mysore o mesmo sistema esta em teste, no entanto, substituem o gás de cozinha. Como afirma Kapur, programas piltoto esão sendo considerados também em Delhi e Bihar.

A focalização do programa obedece as regras do PDS. Os beneficiários devem ter renda inferior a linha nacional de pobreza e, ainda, realizar um cadastro junto as autoridades locais.

In addition to the existing transfer programs and the state-level efforts to reform delivery of benefits, the central government has recently proposed to replace subsidies for kerosene, LPG and fertilizers with direct transfers (Kapur, 2012).

Mesmo sem muitos dados sobre os resultados efetivos desta substituição, ao final de 2012 o Governo Nacional Indiano, propôs a ampliação deste sistema a todo o território nacional. Tal avanço pode indicar que, ao menos, os custos deste novo sistema são menores do que o anterior. A Task Force for Direct Transfer of Subsidies conclui:

One of the priorities that have emerged in recent years is the need to strengthen India's social safety net and improve the delivery mechanisms of poverty alleviation programs. This is to ensure that vulnerable groups can withstand unforeseen shocks to income and continue to access basic goods and services at affordable prices. The 2011-12 Budget has accordingly planned for increases in expenditure to meet these goals, and also recommended direct subsidy transfers to improve the efficiency and reach of welfare benefits for the underprivileged. (TFDTS, 2011:1)

Neste caso se trata de uma programa de transferência incondicional de renda. Isso pois, não é exigida nenhuma contrapartida ao beneficiários. Esta política se assemelha ao programa brasileiro Auxilio-Gás anterior a implementação do Bolsa-Família.

Pode-se incluir este sistema no modelo de política pública de redes de segurança propostos pelo Banco Mundial anteriormente ao chamado springbords que atualizou a a agenda da Instituição 


\section{Programa piloto de substituição do PDS por transferências de renda.}

A terceira experiência piloto está em andamento desde janeiro de 2012. Realizada na colônia de Raghubir Nagar em West delhi, o programa substituir a compra de alimentos nas lojas do PDS por uma quantia mensal em dinheiro. Outros pilotos com a mesma característica ocorrem nos estados de Bihar e Madhya Pradesh. (SEWA, 2013)

Ao todo, 450 famílias foram selecionadas para o programa piloto conduzido Self Employed Women"es Association SEWA. Iniciativa foi financiada e apoiada pelo Governo da Índia, PNUD Índia e Unicef. O primeiro fator de interesse é que o piloto foi proposto e conduzido por uma entidade da sociedade civil, cujo principal missão é a promoção emancipação financeira das mulheres indianas.

O interesse desta organização tem origem em um aspectos comuns ao Bolsa Família e Oportunidades. No modelo latino americano de TDCRs, as mulheres da família são as receptoras primárias do dinheiro e muitos diagnóstico apontam para o caráter emancipador gerado por esta característica. (Soares, 2010)

Das 450 famílias cadastradas, 100 se dispuseram a receber transferências diretas em substituição ao $\operatorname{PDS}^{51}$. Durante um ano, tempo de duração do programa piloto, estas família foram impedidas de retirar qualquer quantidade de alimento da loja de distribuição local.

Os resultados da avaliação inicial indicam o sucesso da experiência, uma vez que a quase totalidade das beneficiárias relatam preferir o novo modelo ao antigo. Os principais motivos relatados fora: a) maior liberdade de escolha de alimentos, e o e a possibilidade de escapar das filas da loja local do PDS. (SEWA, 2013)

O documento da avaliação termina com a recomendação ampliação do programa, inicialmente por adesão voluntária e, em seguida, a substituição completa do PDS. (SEWA, 2013)

O sucesso do piloto gerou repercussão entre os membros da IPC. Em entrevista a mídia Indiana, o atual presidente comemorou os resultados e defendeu a da expansão da iniciativa para toda a nação. (Forbes Índia, 2013)

\footnotetext{
${ }^{51}$ A participação no programa é voluntária
} 
Apesar das constantes referencias ao Bolsa Família e Oportunidades nos documentos, avaliações e declarações dos envolvidos neste processo, trata-se de uma política de transferência incondicional de renda. Apesar do foco da política ser a redução da pobreza, assim como no caso dos derivados de petróleo, nenhuma condicionalidade é exigida dos beneficiários. 


\section{Conclusões.}

1. Existem evidências concretas de que a Índia esta em processo de transformação de seu sistema de proteção social em direção a um modelo baseado em Transferências Diretas de Renda defendido pelo Banco Mundial

Como já apresentamos anteriormente nesta tese (Ver cap 4), o novo modelo de proteção social defendido pelo Banco Mundial, entre outras características, prevê o foco na redução da pobreza, o estabelecimento de programas focalizados que estabelecem uma rede de segurança para as populações vulneráveis. O principal formato de política defendida pelo Banco Mundial são as transferências diretas de renda.

Tanto a transformação do cálculo da linha nacional de pobreza, como a intensão de substituir o PDS por TDRs são evidencias de aproximação das ações do governo indiano aos novo modelo de proteção social proposto pelas agencias multilaterais de desenvolvimento.

2. Apesar das constantes referências ao modelo lationamericano de TDCRs, na prática os programas em implementação na Índia não incoporam as características do Bolsa Família e Oportunidades.

Como descrito acima, os programas de combate a pobreza estão sendo substituídos por Transferências Diretas Incondicionais de Renda. Apesar de diversos autores indianos confundirem TDCRs e TDIRs, as políticas de transferência diretas de renda em teste no país não exigem condicionalidades de seus beneficiários, não investem no capital humano das famílias e nem procuram gerar mudanças de longo prazo e quebras nos ciclos geracionais de pobreza. 
Parte IV - Diálogos 


\section{Apresentação}

Nesta parte, diante de tudo que já foi apresentado nesta tese, retomamos o debate teóricometodológico que iniciamos na primeira parte do texto. Se naquele momento o objetivo foi o de estabelecer fundamentos para abordar o objeto de estudo, nesta parte nos dedicaremos a um diálogo com a literatura acadêmica sobre o desenvolvimento.

No primeiro capítulo buscamos apresentar e discutir os valores incorporados pela narrativa hegemônica do desenvolvimento da experiência societal moderna europeia. Como o centro de poder do sistema mundo atual é também o centro étnico do projeto do desenvolvimento nos propomos a uma breve exploração da conexão entre ambos.

Em especial, o capítulo inicial desta parte, tem como foco os fundamentos temporais e espaciais comuns a narrativa moderna e do desenvolvimento. A imagem linear do progresso como caminho para a emancipação humana e a definição do centro étnico do projeto moderno e do desenvolvimento valores centrais abordados. O diálogo também está centrado na maneira como narrativa do desenvolvimento representa uma tentativa de deslocamento do discurso moderno para além de seu centro étnico de origem e os impactos de tal processo.

No segundo capítulo, com base em um sobrevoo a teoria do desenvolvimento, propomos uma discussão sobre algumas características da narrativa hegemônica do desenvolvimento evidenciadas ao longo da investigação discurso do Banco Mundial.

Avaliamos também alguns dos diferentes posicionamentos teóricos críticos à narrativa do desenvolvimento. Tal discussão abre caminhos para retomarmos a importância de uma abordagem espacializada aos fenômenos do desenvolvimento.

Por fim, no terceiro capítulo, procuramos avaliar a temporalidade intrínseca a narrativa como relato histórico. O discurso do desenvolvimento é apresentado em forma de narrativa histórica linear e universal, tais características não são perceptíveis apenas pelos valores 
expressos pelas agências multilaterais como o Banco Mundial. A própria narrativa é um formato de relato que pressupõem a centralidade da categoria epistêmica tempo. 


\section{Capítulo 7 - Modernidade e Desenvolvimento}

Não é possível dissociar o tema do Desenvolvimento do debate sobre a modernidade. São fenômenos societais que comungam tanto de um mesmo centro étnico de origem quanto de fundamentos ideológicos e epistemológicos. Propomos neste primeiro diálogo uma breve imersão na narrativa sociológica sobre a modernidade em busca de alguns dos traços comuns ao discurso hegemônico do desenvolvimento.

Em especial, o foco deste capítulo são as ideias de tempo e espaço presentes na narrativa moderna. A visão hegemônica e etnocêntrica refletida na literatura acadêmica e no discurso das agências de desenvolvimento pressupõem uma ideia de tempo universal no qual transcorre um processo histórico progressivo e linear.

A esta temporalidade se soma também a construção de fronteiras espaciais expressas tanto na narrativa da modernidade quanto do desenvolvimento. Há, portanto, uma quebra espacial entre o centro étnico moderno, ou norte global, apresentado como espaço mais avançado na trajetória temporal do progresso e o sul, território marcado pelo atraso e incompletude.

Portanto, neste capítulo procura apresentar e discutir estes aspectos temporais e espaciais que se encontram na narrativa da modernidade e que se reproduzem no discurso hegemônico das agências de desenvolvimento.

A narrativa sobre a modernidade 
Gurminder Bhambra no livro Rethinking Modernity (2007) sugere que a narrativa sobre a modernidade se ergue sobre duas quebras, uma temporal e outra espacial:

The fundamental characteristics of the emerging theoretical paradigm were twofold: first, the assumption of a ruptural break from the past that made the modern world discontinuous from, and 'after', that which had preceded it, and, second, an assumption of the uniqueness of 'the West' in its initiation of a distinctive form of society. (Bhambra 2007:34)

Segundo a autora, o discurso sobre a modernidade contém a afirmação de descontinuidade histórica, que marca o início de uma nova etapa - quebra temporal - e a enunciação da excepcionalidade do ocidente - quebra espacial.

(...) the idea of modernity expresses an ambivalence on modernity as an epoch - a period in historical time - and as a time consciousness - a consciousness of time. Clearly it is both, and many of the great visions of modernity were attempts to reconcile these two ways of conceptualizing the present moment: modernity can be seen both as an idea - a cultural impulse, a time consciousness - and as a historical event, a social condition, an epoch in historical time. (Delanty, 2000:11)

No entanto, como afirma acima Delanty (2000), a modernidade representa mais do que uma descontinuidade histórica e designa também uma consciência temporal. Na primeira parte deste capítulo nos deteremos a esta nova temporalidade.

a) A quebra temporal

Como afirma Ricouer (2000), que discutirmos em detalhe no último capítulo desta parte, para estabelecer qualquer narrativa histórica não inclui somente uma ideia de tempo, mas também, estabelecer ou identificar mudanças - situações terminais e iniciais.

Para que la historia llegue a ser una historia de larga duración, convirtiéndose en historia social, económica o cultural, ha de estar vinculada al tiempo y dar cuenta de los cambios que vinculan una situación terminal a una situación inicial. (Ricoeur 2000:193)

O nascimento da modernidade coincide com o surgimento da narrativa moderna. A ruptura dota a modernidade de unicidade, pela qual opõem-se tanto ao modelos que o antecedem, como aos demais espaços de experiência. 
The term 'modern' and its derivatives come from the Latin modus which means 'measure,' and, as a measure of time, 'just now' with the late Latin derivative modernus, from which all later forms derive. (Gillespie 2008:2)

Como sugere Vico, com quem também estabeleceremos um diálogo específico no último capítulo desta parte, as explorações do mundo das nações começam pela etimologia da palavras. Modernus, é vocábulo latino com origem na palavra Modus (medida), é o antecessor direto do termo modernidade e significa medida temporal. (Gillepie, 2008).

The word "modem" in its Latin form "modernus" was used for the first time in the late 5th century in order to distinguish the present, which had become officially Christian, from the Roman and pagan past. With varying content, the term "modern" again and again expresses the consciousness of an epoch that relates itself to the past of antiquity, in order to view itself as the result of a transition from the old to the new." (Habermas 1981:3)

Como denota a citação acima, a palavra Modernus refere-se, desde sua primeira aparição, a uma quebra. No sentido original do vocábulo indicava a passagem entre o pensamento oficial cristão no século $\mathrm{V}$, com o passado pagão romano (Habermas, 1981).

De acordo com Gillespie, o termo Modernus só ganhou constância e importância ao longo dos séculos XVI e XVII quando deixou de representar um fenômeno restrito a religião e assumiu ampliando-se para indicar um fenômeno societal. O primeiro registro (ruína) desta ressignificação da palavra Moderno, agora metamorfoseada em uma nova etapa da tempo, ocorrei em 1585 no idioma inglês:

\footnotetext{
"Cassiodorus used the term (Modern) in the sixth century to distinguish his time from that of the earlier Roman and patristic authors. The term modernitas was used in the twelfth century to distinguish contemporary times from those of the past. Shortly thereafter, the term began to appear in the vernacular. Dante used the Italian moderno around 1300, and in 1361 Nicholas of Oresme used the French moderne. However, the term was not used to distinguish 'ancient' and 'modern' until 1460 and was not used in its contemporary sense to distinguish a particular historical period until the sixteenth century. The English term 'modern' referring to modern times first appeared in 1585, and the term 'modernity' was not used until 1627." (Gillespie 2008:2 and 3)
}

Já o termo modernidade, tributário da palavra moderno, foi criado para designar um novo projeto societal europeu teve seu primeiro registro em 1627. As referências etimológicas, nos servem para identificar as primeiras evidências do surgimento da narrativa histórica 
moderna. Habermas (1981), apesar destas referências anteriores, atribui o início da percepção da modernidade como projeto consciente ao pensamento iluminista Europeu, no século XVIII.

The project of modernity formulated in the $18^{\text {th }}$ century by the philosophers of the Enlightenment consisted in their efforts to develop objective science, universal morality and law, and autonomous art, according to their inner logic. At the same time, this project intended to release the cognitive potentials of each of these domains to set them free from their esoteric forms. The Enlightenment philosophers wanted to utilize this accumulation of specialized culture for the enrichment of everyday life, that is to say, for the rational organization of everyday social life. (Habermas, 1981:9)

A opção habermasiana é fundamental pois denota, ao mesmo tempo, dois aspectos centrais a esta tese. Por um lado, ele relaciona a organização societal moderna a ideia de projeto, atribuindo-a de intencionalidade. A modernidade, ao olhos do pensador alemão busca capturar e objetificar o social.

Por outro, a modernidade aparece em seu pensamento como um fenômeno essencialmente europeu. O caráter endógeno que a modernidade assume na perspectiva de Habermas confirma a visão de Bhambra que na narrativa hegemônica há também uma quebra espacial.

O projeto iluminista de modernidade ao qual Habermas se refere não é fruto de um único pensador, mas de um movimento intelectual que agrega múltiplas leituras. Immanuel Kant é, sem dúvida u definem dos mais significativos entre eles. Em seu texto, O que o Iluminismo? de 1784, o filósofo alemão define o novo momento histórico de iluminação da seguinte maneira:

Enlightenment is man's release from his self-incurred tutelage. Tutelage $\mathrm{s}$ man's inability to make use of his understanding without direction from another. Self- incurred is this tutelage when its cause lies not in lack of reason but in lack of resolution and courage to use it without direction from another. Sapere aude! "Have courage to use your own reason!"- that is the motto of enlightenment.

If we are asked, "Do we now live in an enlightened age?" the answer is, "No", but we do live in an age of enlightenment. As things now stand, much is lacking which prevents men from being, or easily becoming, capable of correctly using their own reason in 
religious matters with assurance and free from outside direction.

(Kant, S/D )

A transformação social, metaforizada pelo desenvolvimento individual, apresenta a modernidade, ou esclarecimento, como o começo do processo de emancipação humana. A Europa aos olhos de Kant atingia a sua maturidade. Como afirma Delanty sobre o pensamento do autor (2000):

Enlightenment is mankind's exit from its self-incurred immaturity, he argues. In his words, 'immaturity' is the inability to make use of one's own understanding without the guidance of another and it is 'self-incurred' when there is a lack of resolution and courage to use it without the guidance of another. (Delanty, 2000:11)

O pensamento de Kant expõem três características da narrativa da modernidade fundamentais a esta tese, uma vez que são também incorporadas ao discurso do desenvolvimento. São elas:

a) A modernidade se inicia com o rompimento da tutela religiosa e caminha em direção a emancipação humana;

b) O movimento histórico é marcado pelo progresso;

c) A emancipação humana, como imagem de futuro, representa a incorporação de um elemento ideológico e utópico.

O pensamento de Immanuel Kant é apenas um dos exemplos que poderiam ser utilizados para levantar as caracterizações do iluminismo sobre a modernidade. Visões semelhantes são encontradas no pensamento enciclopedista francês, como em Condorcet e Turgot, no iluminismo anglo-saxão de Adam Smith e Fergusson, e no pensamento de Herder na Alemanha. (Gilespie, 2008)

De maneira geral, é o iluminismo, visto como primeiro local de enunciação consciente do novo modelo societas por meio de uma narrativa histórica é também de acordo com Delanty, o princípio de uma nova consciência temporal a Europa. De forma sintética, a Europa do século XVIII constitui o experiência percebido pelos pensadores de então como um momento de ruptura com o passado e o início de um processo de emancipação.

The seventeenth-century debate can be seen as a heightened consciousness of the uniqueness of the present moment. The moment of modernity exists in the space between present and past for the modern is not only an epoch that lives for the future, but is one that is formed out of a particular conception of history. The 
critical appropriation of the past provides the modern spirit with its central driving thrust. The overcoming of an origin is part of this way of thinking, which ties the moment of the present to an act of historical appropriation. (Delanty, 2000:09)

Segundo Hammer (2011), a narrativa moderna não enuncia somente uma fratura fundadora, mas estabelece uma dinâmica própria composta de uma sucessão de quebras atribuem a modernidade de movimento histórico singular. Estas constantes rupturas são ocasionadas pelo continuo desenvolvimento da razão e da ciência e estabelecem o fundamento da ideia de progresso.

Autores modernos desde Bacon, Descartes, Turgot e Rousseau, depositam sua fé na humanidade por meio dos avanços da ciência experimental. São os rompimentos constantes com o passado, ocasionadas pelo avanço tecnológico, que dotam de sentido positivo o processo histórico na visão moderna, cuja direção aponta para a emancipação humana.

\begin{abstract}
Returning to the idea of time consciousness, we can say modernity is also an awareness that 'the moment' is an 'epoch', stretching forward as well as backwards in time. The future is seen as emanating not from the present as such, but from an event which preceded the present and from which the present also derives its strength. In the age of the Enlightenment, the epoch of modernity is thus seen as the period stretching from the sixteenth century to the eighteenth century, when, as a result of the scientific revolution, the Renaissance, the Reformation and the age of discoveries, the old certainties of the Middle Ages were shattered. The Enlightenment gains its legitimation from a rupture which had already occurred in recent history, that is, with the beginning of modern times. (Delanty, 2000:10)
\end{abstract}

O termo turbilhão, utilizado por Marshall Berman para caracterizar a experiência moderna, parece adequado a descrição do movimento histórico próprio dos novo período em conformação. O sociólogo americano percebe a experiência moderna como dotada em essência de um processo intenso e sistemático de transformações. O resultado desta dinâmica sobre a realidade objetiva é uma percepção temporal caracterizada pela incerteza, efemeridade e velocidade.

Existe um tipo de experiência vital - experiência de tempo e espaço, de si mesmo e dos outros, das possibilidades e perigos da vida - que é compartilhada por homens e mulheres em todo o mundo, hoje. Designarei esse conjunto de experiências como "modernidade". Ser moderno é encontrar-se em um ambiente que 
promove aventura, poder, alegria, crescimento, autotransformação e transformação das coisas em redor - mas ao mesmo tempo ameaça destruir tudo o que temos, tudo o que sabemos, tudo o que somos. A experiência ambiental da modernidade anula todas as fronteiras geográficas e raciais, de classe e nacionalidade, de religião e ideologia: nesse sentido, pode-se dizer que a modernidade une a espécie humana. Porém, é uma unidade paradoxal, uma unidade de desunidade: ela nos despeja a todos num turbilhão de permanente desintegração e mudança, de luta e contradição, de ambigüidade e angústia. Ser moderno é fazer parte de um universo no qual, como disse Marx, "tudo o que é sólido desmancha no ar". (BERMAN 1986:15)

As visões de tempo cíclico ou ritualístico pré-modernas são substituídas por uma ideia linear de alterações constantes rumo a um futuro incógnito, desconhecido, mas emancipatório. (Nisbet, 1985 e Sklair, 2005)Perspectivas como as expressas na Nuova Scientia (Vico, 1948) de Giambattista Vico, em que o movimento histórico era descrito como sendo composto por três fases - Idade Divina, Idade Heroica e Idade Humana - de um ciclo que tornaria a se repetir a após a conclusão da terceira.

A ideia de progresso e a crença em um futuro de emancipação fundamentado na evolução técnica e científica, que também são centrais ao discurso do projeto do desenvolvimento. Robert Nisbet (1982), define progresso da seguinte maneira:

"Simply stated, the idea of progress holds that mankind has
advanced in the past - from some aboriginal condition of
primitiveness, barbarism, or even nullity - is now advancing, and
will continue to advance through the foreseeable future." (NISBET
1982:4)

A ideia moderna de progresso é percebida pelos historiadores a partir de perspectivas diferentes. Por um lado, estão os defensores de que trata-se de uma visão inovadora e, portanto, intrínseca ao mundo moderno e fruto da ruptura com o passado enunciada pelos pensadores iluministas. De outro, estão os que identificam o progresso como a secularização da teleologia cristã, processo no qual o paraíso é substituído pela emancipação humana. Nesta última a quebra com o passado medial parece menos intensa. (Delanty, 2000)

No entanto, nenhuma das duas teses nega por completo a ruptura entre moderno e prémoderno, a divergência se limita a intensidade da mesma. Segundo Sklair (2005), independente da força que se atribui a quebra entre o moderno e o pré-moderno, será somente a partir da renascença que uma perspectiva de transformações históricas baseada 
no progresso atingirá condições materiais para difundir-se. Será neste momento, que o espaço europeu está preparado [ara reconhecer socialmente o progresso como um movimento real. Em sintonia com esta perspectiva, Delanty identifica o final do século XVIII como o momento em que a sociedade europeia incorpora, de maneira generalizada, essa nova consciência temporal moderna:

By this time, modernity - and the modern - had already come to designate a particular kind of time consciousness. The modern was defined by an orientation to the past and postulated an origin from which the present was both a derivation and a distanciation. (Delanty, 2000:9)

Assim, de forma sintética, o pensamento iluminista, lócus por excelência de enunciação do projeto moderno (Habermas, 1981), dota das seguintes características a narrativa que descreve modelo societal nascente:

a) É estabelecia uma ruptura fundadora de um novo período histórico que é identificada por muitos caminhos - econômicos, simbólicos, ideológicos - mas fundamentam o surgimento de uma nova consciência temporal.

b) O novo período é caracterizado como um processo que irá proporcionar, ao seu final, a emancipação humana.

c) A dinâmica de transformações aponta para uma dinâmica linear e progressiva do processo histórico. Esta dinâmica é imposta pela constante inovação técnica.

d) Esta narrativa da modernidade pode ser caracterizada como um projeto, na medida em que se trata de uma formulação consciente e articulada por agentes sociais.

\section{O projeto moderno transborda ao continente europeu}

Como já afirmamos acima a nova temporalidade expressa no discurso moderno europeu a percebe como um processo endógeno aquele espaço de experiência. No entanto, apesar desta faceta da narrativa que acompanha este modelo societal desde seu centro étnico Tanto o projeto moderno, quanto o do desenvolvimento, não irão se restringir ao espaço europeu. 
A modernidade é em mais do que uma caracterização de um modelo europeu e se constitui também como um fluxo que dissemina desde o seu espaço original de experiência por meio das ações de agentes sociais o longo do processo de expansão marítima europeia.

A narrativa moderna constituída a partir e para um espaço específico de experiência, ao aportar nos demais territórios do mundo se transfiguram em um discurso que se pretende universal. Os demais espaços do sistema mundo em formação passam a ser incorporados de uma maneira subalterna a esta narrativa totalizante.

A quebra espacial, identificada por Bhambra no discurso moderno definem as fronteiras do centro étnico do projeto moderno europeu. Estes limites espaciais também a base de um sistema de classificação que divide os territórios tanto em externo e interno quanto em moderno e não moderno.

"Al definir un espacio, al trazar unos bordes, al mismo tiempo se
define un interior y un exterior. Entonces, si se entiende la
modernidad como un proyecto civilizatorio, lo que está en juego
con ella es la configuración de un nosotros-moderno en nombre del
cual se interviene sobre territorios, grupos humanos,
conocimientos, corporalidades, subjetividades y prácticas, que en
su diferencia son producidas como no-modernas." (Restrepo,
$2010: 18$ )

Essas fronteiras estabelecem o lócus original de irradiação do discurso da modernidade nos termos de Walter Mignolo expõem o centro étnico do mapa moderno do globo (Mignolo, 2003).

A passagem da narrativa moderna dos limites territoriais europeus e a elevação deste discurso a condição de universal, constitui o que Samir Amin (1989) chama de eurocentrismo. No entanto, aos olhos do sociólogo egípcio reside neste deslocamento entre o regional e o universal a principal contradição da narrativa moderna mundializada:

"Eurocentrism is a culturalist phenomenon in the sense that it assumes the existence of a irreducible distinct invariants that shapes the historical paths of different peoples. Eurocentrism is therefore anti-universalist, since its not interested in seeking possible general laws of human evolution. But it does present its self as universalist, fore it claims that imitation of the Western model by all peoples is the only solution to the challenges o four time." (AMIN, 1989:VII)

O eurocentrismo, da maneira como é apresentado por Amin, descreve o processo de universalização dos valores do modelo ocidental aos demais espaços do mundo. A 
transição entre o local e o universal é uma evidência tanto da força de dominação epistêmica quanto militar e econômica que a Europa atingiu neste período.

Portanto, a disseminação do modelo societal moderno se baseou nas relações desiguais entre o centro e a periferia que foram desenhados naquele momento. A disseminação do modelo societal moderno se configura, de acordo com a terminologia adotada por Milton Santos (2008) como um fluxo de caráter hegemonizante. O geografo brasileiro, em sua análise do espaço global, afirma que este é constituído de fluxos de caráter hegemonizante e hegemonizado:

"considerado como uma todo o espaço é um teatro de fluxos com
diferentes níveis, intensidades e orientações. Ha fluxos
hegemônicos e hegemonizados, fluxos mais rápidos e eficazes e
fluxos mais lentos. O espaço global é formado de todos os objetos
e fluxos." (SANTOS, 2008:49)

Se a definição de fluxo hegemônico esta assentada em uma disseminação realizada por meio de relações desiguais a narrativa moderna ao aportar o sul global se torna dominante nos próprios espaços periféricos. Ou seja, os povos subalternizados assumem como seus, os valores, as ideologias e as utopias que fazem parte da narrativa moderna.

Portanto, a narrativa moderna se difunde em fluxo hegemônico e também se estabelece como hegemônica nos espaços colonizados pelos europeus. Utilizamos aqui a concepção de hegemonia de Ana Esther Ceceña, definida como:

"la capacidad de generar una concepción universal del mundo a partir de la propia, de dominar a través del consenso y de reproducir las formas de dominación en los espacios de los dominados." (Ceceña, 2004:06)

A incorporação dos valores societais eurocêntricos pelos actantes sociais do sul global faz com que estes também se tornem agentes difusores da narrativa moderna, como denota o pensamento de Grosfogel (2007):

"El eurocentrismo sólo surge cuando la historia particular de Europa (y, en la segunda mitad del siglo XX, la de Estados Unidos) y la formación subjetiva concomitante se promueven e imponen como un modelo universal, y los sujetos coloniales las aceptan en su adhesión a un modelo para ser lo que no son" (2007c: 100). Es en este sentido que el eurocentrismo "[...] es un fundamentalismo que no tolera o acepta la posibilidad de que existan otros epistemes o de que no-europeos puedan pensar" (Grosfoguel 2007:337) 
Esta capacidade de difusão e imposição de valores pelo sul global adiciona uma outra faceta ao universalismo europeu. Como afirma Dussel, trata-se de um fenômeno singular que vai além do etnocentrismo característico a todas as demais culturas. Isso pois, mesmo que de maneira incompleta, a Europa estabelece de fato um sistema de universalidademundialidade que suplanta as demais culturas locais:

[...] aunque toda cultura es etnocéntrica, el etnocentrismo europeo moderno es el único que puede pretender identificarse con la "universalidad-mundialidad" (Dussel, apud Restrepo,2010:135)

Esse processo de hegemonização dos valores modernos é descrito por Anibal Quijano como Colonialidade de Saber. Não semente os espaços são colonizados e submetidos a lógicas econômicas exploratórias, mas o próprio saber local é reduzido a uma condição de folclore diante da "maturidade" do saber científico europeu.

En este sentido, se puede afirmar que con la noción de colonialidad del saber se pretende resaltar la dimensión epistémica de la colonialidad del poder; se refiere al efecto de subalternización, folclorización o invisibilización de una multiplicidad de conocimientos que no responden a las modalidades de producción de 'conocimiento occidental' asociadas a la ciencia convencional y al discurso experto. (Restrepo, 2010:136)

O saber metropolitano, chamado aqui de narrativa moderna, se apresenta como universal por seu caráter pretensamente objetivo. Assim se esconde sob esse véu tanto o centro étnico no qual ele é produzido quanto a singularidade cultural que nele está inscrito.

La objetividad y neutralidad suponen un conocimiento sin sujeto, o mejor, un conocimiento donde el sujeto toma distancia de sí para producir un conocimiento 'no contaminado' por sus particularidades e sus intereses. Este distanciamiento de sí, esta supresión de los efectos de la mundanal subjetividad, es condición de posibilidad para generar un conocimiento válido, un conocimiento con pretensión de validez universal. (Restrepo, 2010:138)

No entanto, o deslocamento espacial da narrativa moderna impacta nos sentidos dos valores neles inscritos estes aportam nos demais territórios. Não possível manter todos os aspectos intactos de um discurso quando este é submetido a condições e situações completamente diversas. 
De acordo com foco deste trabalho, nos deteremos as transformações que podem ser notadas atribuídos as ideias de progresso e da emancipação humana quando esta são deslocadas do centro a periferia do sistema mundo.

Shiv Visvanathan ${ }^{52}$ se pergunta ao longo de sua palestra sobre as epistemologias do sul: "como palavras que encarnam o espírito do breve século XX, entre estas desenvolvimento, se perderam?” No caso da Índia, prossegue, “esta se torna equivalente a desplaçamento /destituição /deslojamento".

A questão proposta pelo sociólogo indiano, ilustra o fenômeno que queremos descrever. A utopia emancipatória do progresso é sinônimo de um movimento histórico carregado de positividade e que por meio do avanço científico e tecnológico aponta em direção a emancipação humana.

Como pudemos notar no pensamento de Kant acima o esclarecimento é o início da maturidade humana alcançada por meio da superação das fantasias religiosas. O fundamento da nova temporalidade proposta pela narrativa moderna é o progresso.

A mesma ideia de progresso quando transplantada ao sul global sofre muitos impactos em especial pois estes espaços onde ainda não se atingiu o estágio da maturidade, nem econômica, nem societal. O desenvolvimento é justamente o processo que levaria estes territórios a atingir o estágio de progresso do centro étnico do capitalismo.

Como já vimos no capítilo sobre o Banco Mundial (Ver capítulo 4), autores como W. W. Rostow, que escreve uma das obras mais influentes sobre o BIRD, afirmam que o desenvolvimento é a passagem de uma sociedade tradicional em direção ao modelo societal norte americano.

É preciso portanto, por esta lógica desconstruir os modelos locais e substituílos pelo modelo societal moderno eurocêntrico. Ou seja, o que é percebido desde o norte como uma transformação necessária em direção ao progresso quando visto desde o sul global, esta mesma mudança é vista como ações de destituição e desalojamento.

Em termos concretos, uma usina hidroelétrica, para o Banco Mundial, significa uma transformação em direção ao crescimento econômico e progresso, mas é re-significada como destituição para as comunidades ribeirinhas afetadas por sua construção.

\footnotetext{
${ }^{52}$ Spaces of Transformation: Epistemologies of the South Reinventing Social Emancipation
}

Tate Modern, Starr Auditorium. 28 April 2012 
Ao contrário do que afirma Visvanathan, estes termos não perderam seu sentido original com o tempo, mas se transformam - em sentido e conteúdo - no deslocamento espacial entre centro e periferia.

O mesmo processo de deslocamento de sentidos é descrito por Chatterjee sobre a nação periférica que, de acordo com o autor, se constitui como um fenômeno heterogêneo na periferia e homogêneo no centro étnico do projeto moderno.

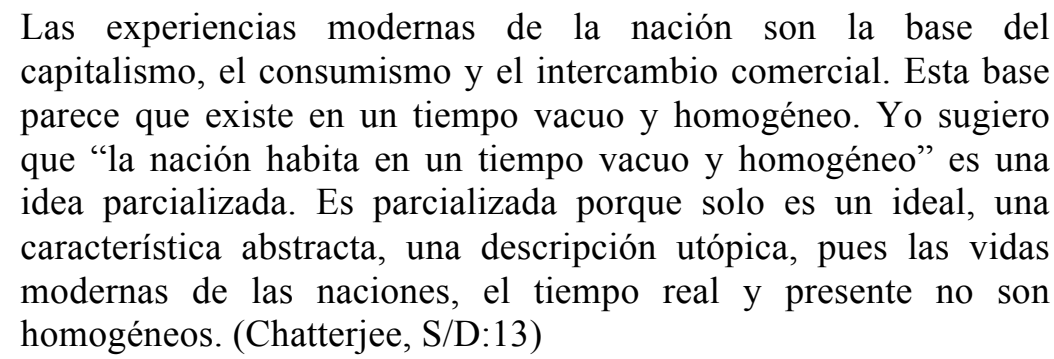

Essa heterogeneidade, destaca o professor da universidade de Kolkata, é evidenciada pelas diferentes relações que o Estado-Nação subalterno estabelece com os que vivem no seu território. No norte, o Estado percebe os habitantes do país, com raras exceções ${ }^{53}$, como cidadãos.

A condição de cidadão imbuído de direitos atribuída pelo Estado Nação do norte a seus nacionais é decorrente da experiência histórica europeia. As democracias modernas do velho continente foram erguidas em oposição a estratificação feudal e, portanto, garantidora - em tese - dos princípios liberais de liberdade e igualdade $\mathrm{O}$ conjunto de cidadãos que se encontram sob um Estado erguido sobre este princípio formam o que se convenciona chamar de sociedade civil.

No sul global, o quadro é bem diverso. Os Estados Nacionais nestes territórios são, em sua maioria, originários do processo de expansão e colonização europeia. Os governos dos territórios periféricos, segundo o sociólogo indiano, não reconhecem o status de cidadão a todos os que nele vivem. Isso pois, enquanto a elite local é tratada pela lógica dos direitos, formando uma sociedade civil excludente, os demais são relegados a condição de população. Com este grupo, de acordo com Chatterjee (S/D) o Estado Nação estabelece uma relação civilizatória por meio de políticas públicas. O trecho abaixo denota a visão do autor sobre a heterogeneidade do Estado subalterno:

\footnotetext{
${ }^{53} \mathrm{O}$ Autor cita imigrantes e ciganos como as principais exceções
} 
Los ciudadanos constituyen la sociedad civil mientras que las poblaciones constituyen la sociedad política. Los ciudadanos de la sociedad civil ocupan el ámbito de la nación homogénea, suerte de ideal ciudadano; enunciado, que sirve como fundamento ético, donde los ciudadanos formulan sus demandas al Estado nación. Como sabemos, estas ideas provienen de las teorías tanto clásicas como liberales. Por otro lado, lo que yo estoy señalando es el papel primordial que cumplen las poblaciones en varios países poscoloniales. Estas poblaciones responden a las políticas gubernamentales. De esta manera, la sociedad política es heterogénea porque las decisiones de los gobiernos son flexibles y varían a lo largo del tiempo. Por eso, las formas de estas asociaciones son muchas veces moldeadas por clasificaciones específicas que los mismos gobiernos imponen a las poblaciones. (Chatterjee, S/D:13)

As próprias TDCRs podem ser incluídas no rol de ações civilizatórias voltadas as populações do sul global. Isso pois, em última análise, tratam-se de programas cujo intuito é a promoção de transformação em direção a padrões societais modernos.

No entanto, como afirma Bhambra, é preciso também lançar uma crítica ao pressuposto de que a modernidade é um fenômeno puramente endógeno ao continente europeu. A perspectiva decolonial da autora ressoa a visão de Enrique Dussel que opõem o paradigma eurocêntrico ao planetário no qual a modernidade não é apresentada como uma fenômeno endógeno ao continente europeu mas fruto de um sistema mundo interconectado.

Two opposing paradigms, the Eurocentric and the planetary, characterize the question of modernity. The first, from a Eurocentric horizon, formulates the phenomenon of modernity as exclusively European, developing in the Middle Ages and later on diffusing itself throughout the entire world. The second paradigm, from a planetary horizon, conceptualizes modernity as the culture of the center of the "world-system," of the first world-system, through the incorporation of Amerindia, (...) and as a result of the management of this "centrality." In other words, European modernity is not an independent, autopoietic, self-referential system, but instead is part of a world-system: in fact, its center. Modernity, then, is planetary (...) Modernity, then, in this planetary paradigm is a phenomenon proper to the system "centerperiphery." Modernity is not a phenomenon of Europe as an independent system, but of Europe as center. (Dussel, 1998:2)

Ao estabelecer suas fronteiras territoriais, a narrativa moderna não somente determina a origem de sua expansão, cestabelece um sistema classificatório, mas nega a importância das relações com os demais territórios para a formação de seu modelo societal. 
Dussel (1996) representa seu paradigma planetário utilizando o modelo de centro e periferia. Um mapa concêntrico, como apresentamos no capítulo metodológico desta tese (Ver capítulo 2) pressupõem partes inseparáveis e interdependentes. Por esta perspectiva, as fronteiras entre o norte e o sul global evidenciam diferentes posições de poder e não estágios diversos em um processo universal de desenvolvimento.

Segundo Walter Mignolo, por seu caráter eurocêntrico a narrativa moderna silencia-se sobre o que o autor denomina lado negro da renascença. Trata-se do não reconhecimento da importância da colonialidade para a constituição do projeto moderno europeu. Como afirma o próprio autor:

La modernidad es para muchos (para Jurgen Habermas o Charles Taylor) un fenómeno esencialmente o exclusivamente europeo. En estas lecturas, plantearé que la modernidad es, en realidad, un fenómeno europeo, sí, aunque constituido en una relación dialéctica con una alteridad no europea que contiene en sus más remotos confines. La modernidad apare- ce cuando Europa se afirma como el "centro" de la Historia Mundial que inaugura: la "periferia" que rodea este centro es entonces parte de esta definición auto centrada. La oclusión de esta periferia (así como el papel de España y de Portugal en la formación del mundo moderno desde el 'in del siglo XV hasta la mitad del siglo XVII) lleva a los principales pen- sadores del "centro" a una falacia eurocéntrica en su comprensión de la modernidad. Si su comprensión de la genealogía de la modernidad es tan parcial y provincial, sus intentos de crítica o de defensa de la misma son así mismo unilaterales y en parte, falsas. (Dussel, apud Mignolo,2010:18)

O pensamento decolonial de Walter Mignolo e Enrique Dussel denunciam os silêncios ideológicos e epistêmicos da narrativa moderna. Uma crítica semelhante a proposta pelos pensadores decoloniais latino-americanos, já havia sido elaborada no campo da economia pelos teóricos da dependência e do sistema mundo. teoria do sistema mundo constitui crítica semelhante, o discurso moderno não reconhece as relações econômicas desiguais que possibilitaram a sua emergência. Como denota o trecho abaixo de Theothonio dos Santos:

O enfoque do Sistema-Mundo busca analisar a formação e a evolução do modo capitalista de produção como um sistema de relações econômico-sociais, políticas e culturais que nasce no fim da Idade Média européia e que evolui na direção de se converter num sistema planetário e confundir-se com a economia mundial. Este enfoque, ainda em elaboração, destaca a existência de um centro, uma periferia e uma semi-periferia, além de distinguir entre 
as economias centrais uma economia hegemônica que articula o conjunto do sistema. (Santos, S/D:31)

Immanuel Wallerstein (1982), afirma que os sistemas-mundo são uma arena espaçotemporal em que a ação social ocorre. Sua perspectiva teórica da importância central as relações estabelecidas entre os diversos espaços conectados econômica e culturalmente.

No discurso do projeto hegemônico do desenvolvimento, por exemplo, em nenhum momento se nota a necessidade de romper as relações econômicas desiguais entre o norte e o sul global. Para o Banco Mundial tanto o desenvolvimento quanto o subdesenvolvimento são fenômenos endógenos aos diferentes países.

Romper com a cartografia do linear do discurso hegemônico moderno oferecer uma leitura do progresso e do desenvolvimento como um fenômeno que transcorre no espaço. Tanto o modelo societal moderno quanto os modelos de desenvolvimento foram constituídos em um sistema de relações e se difundem por ele. Esta perspectiva constitui o chamamos aqui de abordagem espacializada. (Ver capítulo 2)

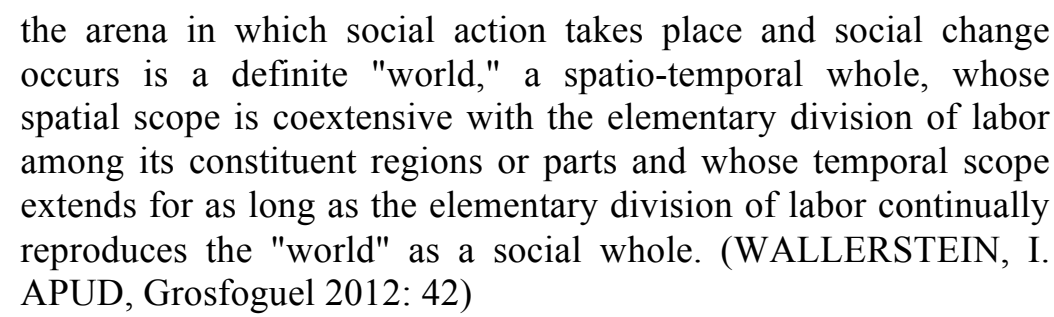

No discurso do projeto hegemônico do desenvolvimento, por exemplo, em nenhum momento se nota a necessidade de romper as relações econômicas desiguais entre o norte e o sul global. Para o Banco Mundial tanto o desenvolvimento quanto o subdesenvolvimento parecem fenômenos endógenos aos diferentes países, cuja superação depende apenas de ações locais.

Conclusão:

De maneira sintética, este capítulo procura expor uma dos diálogos com a teoria mais importantes a reflexão pretendida por esta tese. A partir a da afirmação de Gurminder Bhambra sobre a presença de uma quebra temporal e outra espacial na narrativa moderna é possível caracterizar uma temporalidade e uma espacialidade hegemônica. 
A temporalidade linear do progresso que substitui a visões ciclicas pre-modernas e representa a história como um movimento linear e progressivo que serve como base para a classificação dos espaços de acordo com o grau de desenvolvimento.

A espacialidade do discurso moderno estabelece uma quebra entre o centro étnico do sistema mundo. Os territórios externos a este espaço são os que se encontram aquém no nível de progresso dos que estão dentro de suas fronteira. Outro aspecto relevante evidenciada pela ruptura espacial contida na narrativa moderna é o silencio sobre a relevância das relações entre o centro e a periferia para a formação da modernidade europeia.

Como critica a esta narrativa destacamos três pontos: a) a pretensa universalidade dos valores modernos em expansão é confrontada pelo deslocamento das ideias entre centro e periferia; b) a relevância das relações desiguais entre norte e sul global para comprender tanto o surgimento quanto para a expansão do modelo societal moderno e c) a necessidade de romper com a centralidade da temporalidade linear moderna pela atribuição por uma abordagem analítica espacializada. 


\section{Capítulo 08 - A teoria do desenvolvimento e sua narrativa.}

\section{Apresentação:}

No primeiro diálogo nos dedicamos a narrativa da modernidade. Neste o foco será direcionado a teoria do desenvolvimento. Como já discutimos no capítulo anterior, as relações entre os dois fenômenos são intensas o que faz com que a separação completa entre eles não seja possível.

Development thus supposes: a) nature viewed as a set of objects for the service of humans; b) a cumulative, unilinear time, and a notion of progress that posits life as a process of moving toward a better future; c) the bourgeois notion of person and individual; d) the prevalence of economic/market oriented visions (with its consequences such as competition, expropriation, accumulation and fetishism); e) Western capitalist expansion and the ideological production of its inevitability and centrality; f) science and technology as the solutions for humankind's problems; g) a notion of power as accumulation of energy and control. (Ribeiro, 2012:18)

A caracterização do desenvolvimento proposta por Ribeiro expõe, como já afirmamos acima, as conexões entre os fundamentos ideológicos e epistemológicos da narrativa moderna e do desenvolvimento. Em especial, destaca-se de acordo com o debate do capítulo anterior: a) uma visão unilinear de tempo, b) a centralidade do ocidente e c) a importância do avanço tecnológico e científico para a dinâmica do progresso como caminho para a emancipação humana.

Apesar destra base paradigmática comum, uma diferença entre os dois fenômenos merece destaque. Como já discutimos na parte anterior, tanto o modelo societal moderno como o 
projeto hegemônico do desenvolvimento são abordados aqui de maneira a dar destacar a espacialidade destes fenômenos. Parte do tratamento dispensado a estes objetos consiste em analisar a difusão de ambos pelos territórios que se encontram conectados no atual sistema mundo. As relações por relações desiguais estabelecidas entre centro e periferia são os canais pelos quais se deslocam os fluxos de diversas ordens.

I call it a diffuse mode because; a) it has an extraordinary capillarity and power of silent dissemination and b) it is the product of manifold actions of an enormous quantity of subjects and processes that often are difficult to identify, but are responsible for the creation, consolidation and reproduction of the main discourses informing the matrix. The diffuse mode operates by means of largely unconscious macro sociological processes and very long duration historical processes that, in turn, may congeal in institutions and in subtle, or not so subtle, processes of transmission and socialization. I am referring to processes such as the already mentioned disenchantment of the world, the formation of the world capitalist system, the emergence of the bourgeois subject, the expansion of the Western Christian world. (Ribeiro, 2012:21)

Para Ribeiro (2012), a disseminação do modelo societal moderno ocorre de forma difusa. Isso significa que é propulsionado por múltiplos macro-processos e agentes em um processo de longo prazo. A expansão ultramarina europeia, o colonialismo, o imperialismo são diferentes momentos desde grande movimento global.

Por outro lado, o discurso do desenvolvimento se espalha de forma concentrada. Trata-se de um processo mais conciso e ordenado, promovido por agentes institucionais limitados e conscientemente comprometidos com esse projeto de transformação. O fluxo concentrado do desenvolvimento aparece da seguinte forma nas palavras do autor::

In contrast with the diffuse mode, the concentrated mode of dissemination of development discourses is more concrete and structured by processes of medium and short duration in historical time. It is prone to be embodied in mid sized and micro agencies that are involved in the production of discourses, models and actions that are identifiable and tangible. Some of the most important of these agencies were created after World War II when development became a label internationally accepted and used. It is the case, for instance, of the World Bank, created in 1944; the United Nations (1945) and its organisms, such as the United Nations Development Program (1965); the Organization for Economic Cooperation and Development (1961); the World Trade Organization (1995); several regional development banks, such as the Asian Development Bank (1966); and many other institutions 
that make up the international cooperation field. Capitalist firms such as steel industries, civil engineering contractors, oil corporations, and many others - universities and nongovernmental organizations are also main actors within the development power field (Ribeiro 2002). Such agencies and their personnel are responsible for the mechanisms of dissemination typical of the concentrated mode. (Ribeiro, 2012:23/24)

Os agentes promotores de desenvolvimento sistematizam valores e ideologias em ações e políticas públicas. As instituições criadas no período pós-guerra, como o Banco Mundial, se configuram como os principais actantes de promoção das ações e de narrativa do desenvolvimento. Estas são impostas aos países periféricos em fluxo hegemonizante (Santos, 2006), ou seja, baseada em relações de subordinação e dominação. O objetivo último do projeto do desenvolvimento é moldar as nações do sul global de acordo com um padrão de progresso ocidental.

Os valores e padrões de transformação propostos pelas instituições multilaterais de desenvolvimento são incorporados pelos Estados Nacionais da periferia do capitalismo e, portanto, se tornam narrativa hegemônica também nos territórios subalternizados. Cecena (2006).

Outra diferença entre as narrativas do desenvolvimento e da modernidade é a imagem de futuro que ambas apresentam. Como afirmamos no capítulo anterior no discurso moderno o futuro é descrito pela utopia da emancipação humana que seria resultante do esclarecimento e do progresso.

O discurso do projeto do desenvolvimento, como já discutimos no capítulo anterior, se constitui a partir de um deslocamento da ideia de progresso para a periferia do sistema mundo. Estes territórios ainda incompletos e imaturos, segundo o discurso hegemônico, precisariam atingir o estagio de maturidade que os espaços do norte já vivem. Assim, o futuro proposto pela narrativa do desenvolvimento não é constituído de uma imagem etérea de emancipação humana, mas de uma representação idealizada e desterritorializada do modelo societal do centro étnico do atual sistema mundo.

O Banco Mundial e as agências multitlaterais de desenvolvimento propõem transformações ao sul global baseadas nos modelos dos países do norte. Os indicadores e metas estabelecidos para os países do sul nada mais são os que são medidos no norte. A narrativa do desenvolvimento, como afirma Dussel, é linearmente dialética. Isso pois, se 
pretende universal, mas aponta o próprio centro étnico de seu discurso como o fím do processo histórico, nas palavras do autor:

"El desarrollo es linearmente dialéctico: es una categoría ontológica primordial, particularmente en el caso de la Historia Mundial. Tiene, por otra parte, una dirección en el espacio: 'El movimiento de la Historia Universal va desde el este hasta el oeste. A Europa es el fin absoluto de la historia universal'." (DUSSEL, 2001:61)

A lógica linear do progresso, como veremos no capítulo seguinte, propõem uma dinâmica histórica em que o futuro nunca toca o passado. Já a narrativa do desenvolvimento, apesar de aparentemente seguir esta mesma perspectiva, se apresenta, em última análise, como um processo circular. Isso pois, tanto na origem quanto no destino do processo de desenvolvimento está o centro étnico do atual sistema mundo. Dito de outra forma, o discurso do desenvolvimento está baseado na experiência societal do ocidente, incorpora seus valores e, por fim, aponta os espaços periféricos em direção ao seu próprio modelo societal.

No texto que segue, nos detemos a dois objetivos. Primeiro, procuramos identificar de maneira mais detalhada as conexões entre o projeto moderno e do desenvolvimento. Em seguida, realizaremos um breve sobrevoo à teoria e história do projeto do desenvolvimento.

\section{Da Modernidade ao desenvolvimento}

Development is a founding belief of modernity. And modernity is that time in Western history when rationality supposed it could change the world for the better. In development, all the modern advances in science and technology, in democracy and social organization, in rationalized ethics and values, fuse into the single humanitarian project of deliberately and cooperatively producing a far better world for all. (PEET e HARTWICK 2009:2)

A citação de Peet e Hartwick (2009), autores de um dos manuais de desenvolvimento mais utilizados em universidades do norte global e publicado por uma das maiores editoras do 
mundo, incorpora a narrativa do desenvolvimento os aspectos temporais e espaciais do discurso moderno.

Nela se ressalta principalmente: a) a transformação social baseada na ciência, b) o caráter positivo deste processo evidenciado pela utopia de uma vida melhor resultante do progresso e, por fim, a quebra espacial entre centro e periferia notada por Gurminder Bhambra (2007) (ver capítulo anterior). Além disso, caracterizam o desenvolvimento como um projeto intencional e racionalizado.

"Development in the modern sense implies intentional social change in accordance with societal objectives" (Hettne, 2008:23)

$\mathrm{Na}$ definição de desenvolvimento de Hettne, reforça a intencionalidade deste projeto presente na conceituação de Peet e Hartwick. O uso do termo objetivo societal para descrever a motivação deste movimento indica a relação acima explorada em que o futuro na narrativa do desenvolvimento é coincidente com o próprio modelo de organização social do norte capitalista .

"I would insert the criterion of improvement and define development as the organized intervention in collective affairs according to a standard of improvement." (PIETERSE 2010:03)

Pieterse, por sua vez, relaciona o desenvolvimento a um critério de aprimoramento promovido por meio de uma intervenção organizada. O padrão de melhora, corresponde ao progresso científico e tecnológico que, segundo os valores expressos na narrativa moderna, conduz a transformação societal em direção a emancipação humana.

Essas três definições evidenciam algumas das relações entre o desenvolvimento e os valores contidos na narrativa moderna. No entanto, subjaz a todos estes a crença na possibilidade de objetificação do social, ou seja, na discurso do desenvolvimento o mundo é capturável e direcionável de acordo com planejamento e a partir de intervenções humanas.

O padrão societal de transformação promovido pelas agências multilaterais baseado em uma concepção universalista do progresso histórico é uma das evidências de tal faceta do discurso hegemônico do desenvolvimento. Ribeiro (2012) conecta estes valores modernos aos objetivos do projeto do desenvolvimento: 
Anthropologists know that the claim that endless economic growth and technological innovation are the goals to pursue in life is a result of specific and highly powerful processes enmeshed with the history of Western modernity. The latter presupposes the: a) objectification of the natural and social worlds; b) processes of capitalist and industrialist accumulation and differentiation; c) ideologies and utopias such as the notion of progress, as well as evolutionist conceptions of unilinear time. (Ribeiro, 2012:16)

Os elementos ideológicos e utópicos da narrativa da modernidade justificam e direcionam as intervenções do projeto do desenvolvimento. Ao mesmo tempo, as ações das instituições do desenvolvimento contribuem para a universalização dos princípios societais do centro étnico do norte hegemônico.

Forma-se uma relação simbiótica entre a narrativa moderna e o projeto do desenvolvimento. A difusão concentrada do desenvolvimento incorpora valores modernos e, ao mesmo tempo, contribui para o fluxo difuso do projeto moderno.

Desenvolvimento, uma definição instável

Ao longo da história do projeto hegemônico do desenvolvimento, como já descrevemos no capítulo dedicado ao Banco Mundial (ver capítulo 4), os significados da palavra desenvolvimento viveu um processo de expansão. O caminho desde a definição inicial, restrita ao crescimento econômico, até a percepção moderna, que inclui também as políticas sociais, mostra que se trata de um termo, como afirma Escobar, de sentido instável.

\footnotetext{
"Development" is an unstable term. Is it an ideal, an imagined future towards which institutions and individuals strive? Or is it a destructive myth, an insidious, failed chapter in the history of Western modernity (Escobar 1995, Apud Edelman and Haugerud 2008)
}

Tal inconstância não está restrita ao discurso de instituições como o Banco Mundial. A teoria do desenvolvimento também atribui diversos sentidos ao termo ao longo de sua história, que Edelman e Haugerud (2008) divide em três fases. A primeira, corresponde ao período anterior a formalização do desenvolvimento como projeto hegemônico. 
Our first phase of development thought thus includes attempts to understand the rise of capitalism in the 15th and 16th centuries, and the startling changes associated with the emergence of industrial capitalism in the late 18th century. These transformations helped to inspire the teleologies noted earlier, together with conceptions of a "universal history," including Enlightenment, Hegelian, Marxian, and other notions of progress. Indeed, development was seen by some (such as Comte) in the late 19th century as reducing the "disordered faults of progress" (Cowen and Shenton 1996:7), though for many in that era "the idea of development provided a way of narrating world history, but not necessarily a rationale for acting upon that history" (Cooper and Packard 1997:7)." (EDELMAN e HAUGERUD 2008:5,6)

Este período equivale a formação da modernidade como projeto societal. Neste momento, o termo desenvolvimento foi transposto das ciências naturais pela filosofia social. Quando aplicado a natureza a palavra carregava o sentido de maturação e crescimento e indicava o processo pelo qual os seres vivos se transformam em direção ao auge de suas capacidades.

Com as teorias evolucionistas do século XVIII e XIX, a ideia de desenvolvimento sofre uma profunda alteração de sentido. Nesta etapa o termo passa a significar um processo de aperfeiçoamento, pelo qual novas habilidades podem ser incorporadas.

It was between 1759(Wolff) and 1859(Darwin) that development evolved from a conception of transformation that moves towards the appropriate form of being to a conception of transformation that moves towards an ever more perfect form. During this period, evolution and development began to be used as interchangeable terms by scientists. (ESTEVA 2010:4)

$\mathrm{Na}$ formação das ciências sociais modernas, o sentido atribuído a desenvolvimento se aproxima da ideia de progresso, que neste período passa a ser incorporada como um dos valores mais importantes da modernidade. Entretanto, foi apenas a partir da formalização do projeto do desenvolvimento que o termo assume seu conteúdo contemporâneo.

Como já discutimos no capítulo anterior o sentido atual do termo desenvolvimento é resultante do deslocamento da a ideia de progresso do centro para a periferia do sistema mundo. O progresso que no norte capitalista é visto como um processo linear rumo a um futuro emancipatório, se metamorfosea no sul global limitando-se a indicar um caminho de maturação em direção ao estágio já alcançado pelo norte hegemônico.

A perspectiva mais restrita e instrumental adotada pelas agencias multilaterais de desenvolvimento tem origem na dissolução do sistema colonial. (Leyes, 1998) Diante das 
continua condenação da subordinação colonial e das políticas genocidas das metrópoles direcionadas as populações nos territórios dominados, o governo britânico implementou a lei de desenvolvimento e bem estar das colônias, no ano de 1939. Por esta lei, a metrópole passou a se arvorar da obrigação de prover crescimento econômico e cuidar do bem estar dos súditos de todo o império. Como afirma Esteva, trata-se de um instrumento legal de caráter paternalista que imputa a Inglaterra a missão de civilizar os povos bárbaros para que estes pudessem superar a condição de atraso em que viviam, como denota o trecho abaixo:

In the third decade of the century, the association between development and colonialism, established a century ago, acquired a different meaning. When the British government transformed its Law of Development of the Colonies into the Law of Development and Welfare of the Colonies in 1939, this reflected the profound economic and political mutation produced in less than a decade. To give the philosophy of the colonial protectorate a positive meaning, the British argued for the need to guarantee the natives minimum levels of nutrition, health and education. $4 \mathrm{~A}$ 'dual mandate' started to be sketched: the conqueror should be capable of economically developing the conquered region and at the same time accepting the responsibility of caring for the well-being of the natives. After the identification of the level of civilization with the level of production, the dual mandate collapsed into one: development. (ESTEVA 2010:5,6)

Esta visão civilizadora que embasa a nova legislação colonial inglesa é deslocada para as primeiras instituições formais do projeto hegemônico do desenvolvimento A estrita relação entre o discurso colonial e a visão inicial adotada pelas agencias de Bretton Woods, leva Leyes (1996) a apontar que teoria do desenvolvimento neste momento inicial nada mais era do que a busca de caminhos para acelerar o crescimento econômico das ex-colonias.

"Its not a oversimplification to say that development theory was originaly just a theory about the best way for colonial, and then excolonial, states to accelerate national economic growth in the international environment." (LEYES, 1996:7)

Tal visão está em sintonia com os primeiros passos do Banco Mundial em direção a uma definição de desenvolvimento, discutida no capítulo 4 desta tese. Este esforço de transição entre o sistema colonial e as políticas de promoção do crescimento econômico das colônias ao final da segunda guerra mundial constitui o cenário de formalização do projeto 
hegemônico do desenvolvimento. Edelman e Haugerud identificam neste momento o início segunda fase da teoria do desenvolvimento.

The 18th- and 19th-century intellectual traditions of the first phase of development thought were seldom acknowledged in most of the second period, 12 which saw the emergence of a much narrower development theory in the 1950s to deal with "how the economies of the colonies of Britain, France, Portugal and other European powers, colonies comprising some $28 \%$ of the world's population, might be transformed and made more productive as decolonisation approached" (Leys 1996:5). (...) A key precursor to this second period was the 1944 establishment of the Bretton Woods financial institutions (International Monetary Fund and World Bank), together with a system of fixed currency exchange rates, limitations on capital movements across national boundaries, and the institutionalizing of national economic planning to promote growth. The idea of development here was strongly influenced by John Maynard Keynes, the chief British delegate to the Bretton Woods Conference and an advocate of public spending as an engine of growth and source of employment. (EDELMAN e HAUGERUD 2008:6)

Os primeiros anos das agências multilaterais foram voltadas quase exclusivamente a reconstrução europeia e a contenção do avanço comunista. A quase inexistência de ações direcionadas ao sul global leva Gustavo Esteva a afirmar que a era do desenvolvimento só irá de fato se materializar na década 50 e marco inicial da concretização do novo projeto foi discurso inaugural do presidente estadunidense Henry Truman. Como afirma Esteva:

For these purposes, they conceived a political campaign on a global scale that clearly bore their seal. They even conceived an appropriate emblem to identify the campaign. And they carefully chose the opportunity to launch both - 20 January 1949 . That very day, the day on which President Truman took office, a new era was opened for the world - the era of development. (ESTEVA, 2010:I)

O discurso de Henry Truman que se inicia com um arroubo anti-comunista digno do macartismo. Em seguida, o presidente recém empossado declara a excepcionalidade do ocidente e o papel civilizador que os Estado Unidos da América para o desenvolvimento deste momento em diante. Anuncia também, em tom celebratório, o fim antigo imperialismo e a necessidade crescimento econômico, redução da pobreza e combate a fome nas antigas colônias como principais objetivo do desenvolvimento. Por fim, destaca a importância das instituições multilaterais e do conhecimento científico e tecnológico para 
a promoção de um futuro de prosperidade geral, que nunca chegou. (Ver trecho do discurso inaugural de Henry Truman no capítulo 4 desta tese)

Um novo sistema classificatório entra em vigor em substituição a antiga dualidade entre colônia e metrópole. A nova divisão entre desenvolvidos e subdesenvolvidos tem princípio semelhante a fronteira entre modernos e não-modernos discutida na parte anterior.

Este sistema de classificação classificatório baseado em uma visão linear do progresso e uma percepção universalista da história posiciona, como discutimos no capítulo anterior, os diferentes países em uma escala fundamentada no progresso econômico. Como afirma Esteva, em Janeiro de 1949, 3 bilhões de pessoas passaram a ser consideradas subdesenvolvidas

\begin{abstract}
"Underdevelopment began, then, on 20 January 1949. On that day, 3 billion people became underdeveloped. In a real sense, from that time on, they ceased being what they were, in all their diversity, and were transmogrified into an inverted mirror of others' reality: a mirror that belittles them and sends them off to the end of the queue, a mirror that defines their identity, which is really that of a heterogeneous and diverse majority, simply in the terms of a homogenizing and narrow minority." (ESTEVA, 2010:II)
\end{abstract}

Categorizar é ao mesmo tempo unir e separar. A centralidade do crescimento econômico indicada pelo produto interno bruto das nações aplaina sob sua centralidade todos os demais aspectos das sociedade. Esta métrica que será utilizado na fase inicial do projeto do desenvolvimento, por ela se definirá a distancia e o posicionamento das nações no processo universal do progresso.

Como afirma Florestan Fernandes o desenvolvimento não pode ser entendido de forma isolada, pois trata-se, em última instância, trata-se de um sistema de comparação. O trecho abaixo, denota esta ideia:

"tende-se a pensar o desenvolvimento como problema isolado, como se ele desse respeito a uma sociedade dada, considerada em um momento histórico particular. No entanto, em termos sociológicos, ele deve ser encarado através de um grupo de sociedades, que compartilhe um mesmo padrão de civilização, e as diferentes possibilidades que este oferece às sociedades que o compartilham para realizar um destino historicamente comum." (FERNANDES, 1968:166). 
O mesmo princípio do sistema classificatório fundamenta as características e intensidades das intervenções nas ex-colonias. Se para alguns a era do desenvolvimento configura uma declaração de poder, para os demais é uma afirmação de sua incompletude:

(...) for two-thirds of the people on earth, this positive meaning of the word 'development' - profoundly rooted after two centuries of its social construction - is a reminder of what they are not. (ESTEVA 2010:6)

Aos poucos, no entanto, o projeto hegemônico do desenvolvimento amplia as metas e o grau de intervenção das agência internacionais de Breton Woods. Outros aspectos passam a também figurar entre os itens constantes na agenda de desenvolvimento, tais como: organização institucional, parâmetros legais, produção intelectual e promoção do bem estar. Ao longo do capítulo 4 desta tese detalhamos esta expansão no que tange ao Banco Mundial.

Este processo aprofunda o caráter civilizador do desenvolvimento juntamente a crescente influencia destas instituições sobre os países do sul global. Este caminho é resumido por Edelman e Haugeraud da seguinte maneira: "A vision of development as improved well-being, especially in
former colonies, has gradually replaced the unidimensional
economistic measures that neoclassical economists favor, such as
GDP growth or economic rates of return to particular projects."
(EDELMAN e HAUGERUD 2008:1)

As instituições de Breton Woods, principais agentes institucionais de difusão do projeto hegemônico do desenvolvimento, procuram induzir modelos e políticas por meio de financiamentos, compartilhamento de conhecimento e apoio técnico. O Estado Nacional periférico - em si uma incorporação do modelo de organização política e territorial surgido na modernidade - se configura como o principal agente nacional de desenvolvimento.

"Thus, the state came to provide the defining boundaries of 'society', and the 'societies' were the entities witch were comparable one to the other - in the famous billiard-ball analogy, comparable to individuals within all human society. 'Societies' were seen as collective entities going along parallel paths in the same direction. That is to say, it was societies that were developing. Development (or in older terminology, progress) was a measurable (at least describable) characteristic of societies."(WALLERSTEIN 1984:177) 
A nação é o sujeito do desenvolvimento e o Estado nacional o principal mediador entre a realidade local e agencias internacionais. Os governos do sul global são os receptores dos empréstimos internacionais e agentes de transformação.

$\mathrm{Na}$ década de 1970 Edelman e Haugerud identificam o início de um terceiro período da história do desenvolvimento devido a profunda transformações no contexto econômico mundial. Neste momento, a quebra do sistema de controle financeiro das instituições de Breton Woods e sua substituição pelo padrão dólar exacerba ainda mais o poder mundial dos EUA. O pensamento neoliberal dominante nos setores conservadores norte-americanos passa a exercer crescente influencia sobre o projeto do desenvolvimento. As principais direções apontadas para o crescimento econômico e promoção de bem passam a se a ultraliberalização dos mercados internos e a substituição da centralidade do Estado pela do mercado no processo do desenvolvimento

A third development phase begins in the 1970s with the breakdown of the Bretton Woods controls on capital movements (and a consequent weakening of states' capacities to promote national development), the 1971 termination of currency exchange rates fixed to a gold value through the US dollar, and - in the late 1970 s and 1980s - a series of policy changes that were known (outside the United States) as economic neoliberalism. (Inside the United States, the new economic status quo was so taken for granted - so naturalized by institutions of power - that it was seldom labelled or debated at all [Korten 2001:78]).15 What the rest of the world terms "neoliberalism" or "liberalism" - that is, doctrines or policies that accord the market rather than the state the main role in resolving economic and other problems - is typically considered "conservative" in the United States. Or put another way, in the United States neoliberalism is a blend of neoclassical economics and political conservatism. (EDELMAN e HAUGERUD 2008:7)

O caráter civilizatório do projeto do desenvolvimento se acentua. A noção restrita ao crescimento econômico é definitivamente abandonada. Soma-se aos objetivos do norte hegemônico transformações na organização dos estados periféricos e as novas formas de promoção de bem estar. Entre elas, como apresentamos na primeira parte desta tese, figuram o modelo de proteção social baseado em redes de segurança e as políticas de transferência direta de renda.

Outra particularidade deste período foi o drástico aumento da influencia das ag6encias multilaterais sobre os países do sul global. Tal fato foi possibilitado por um cenário de 
fragilidade econômica na periferia capitalista causada pela fim dos controles do sistema Breton Woods e a elevação dos preços internacionais do petróleo que geram crises de balança de pagamento em vários países. A vulnerabilidade econômica aumentou a necessidade de captação de recursos e a dependência do sul em relação ao Banco Mundial. Aproveitando-se deste cenário o Banco Mundial passa a condicionar empréstimos a alterações profundas no estado e nas economias periféricas, as políticas de ajuste estrutural De acordo com Spicker (2009) as seguintes condicionalidades eram exigidas para a obtenção de emprestimos:

Por lo general, la condicionalidad de la estabilización requería alcanzar metas de crecimiento impulsadas por el incremento de las exportaciones (a menudo exportaciones agrícolas a expensas de la agricultura de subsistencia), recortar el gasto público, limitar el endeudamiento, devaluar la moneda, privatizar organismos estatales y liberalizar la economía, entre otras medidas. Los resultados directos e indirectos de muchas de estas medidas afectaron negativamente a los pobres. (Spicker et al, 2009:42)

Gerou-se neste momento um dos mais intensos movimentos de transformação societal dos espaços periféricos e, portanto, uma das estratégias mais bem sucedidas de desenvolvimento. No quadro abaixo, Patnaik evidencia o grau de difusão das principais condicionalidades exigidas naquele momento.

Percentage of Total Number of

Countries Implementing Policy

1. Restraint on Central Government Expenditure $\quad 91$

Limits on Credit Expansion 99

2. Reduction in Ratio of Budget Deficit to GDP 83

3. Wage Restraint 65

4. Exchange Rate Policy 54

O principal resultado social do processo de desestatização, abertura de mercados e de reorganização dos Estados Nacionais, segundo Glauco Arbix, foi o aumento da desigualdade. Este incremento pode ser notado tanto entre as nações do centro e da periferia, como na divisão de riqueza interna ao países do sul. 
No entanto, resultados decepcionantes contrastam com as virtudes anunciadas pela ofensiva liberalizante. A esse respeito, vale a pena relembrar que o fato econômico mais espetacular desde o pós II guerra reside na diferença e contraste da renda que separa - e que vem aumentando - as nações ricas das pobres e entre pobres e ricos dentro de uma mesma região ou país. (ARBIX 2002:2)

A ampliação e intensificação das ambições do projeto do desenvolvimento e seus resultados sociais negativos geram fortes reações. Até então, as pressões sobre as agências de desenvolvimento buscavam impor acertos pontuais em suas políticas. Neste momento, segundo Esteva (2010), o campo do desenvolvimento vive uma das suas principais diásporas. As críticas ao projeto hegemônico do desenvolvimento se intensificam e os rompimentos mais profundos com a utopia do progresso são enunciadas desde o sul global. Segundo a tipologia elaborada Pieterse (1998) para resumir as posições políticas diante do desenvolvimento, as críticas a este projeto podem ser agregadas em dois grupos. Por uma lado está o que o autor denomina o Alternative Development e por outro o que ele chama de Alternative to Development ou Post-Development.

As críticas agrupadas sob o título de desenvolvimento alternativo procuram, segundo Pieterse, impor ajustes nos rumos do projeto hegemônico do desenvolvimento. Apesar de terem logrado alguns sucessos estes acertos não atacam os principais aspectos estruturais e ideológicos do projeto do desenvolvimento.

"Alternative development has been concerned with introducing alternative practices and redefining the goals of development. Arguably this has been successful, in the sense that key elements have been adopted in mainstream development". (PIETERSE, 1998:344).

Exemplos destes ajustes citados pelo autor holandês foram as incorporações de preocupações humanitárias e ambientais as diretrizes das instituições multilaterais de desenvolvimento. No entanto, não atingem o cerne do discurso desenvolvimentista nem as relações de poder nele representados.

"Alternative development can be viewed as a roving critique of mainstream development, shifting in position as mainstream development shifts, as a series of alternative proposals and methodologies that are loosely interconnected; or it can be viewed as an alternative development paradigm, implying a definite theoretical break with mainstream development. It can be viewed as concerned with local development, with alternative practices on the ground, or as an overall challenge to the mainstream, and part 
of a global alternative. In many discussions this question of the status and scope of alternative development remains unsettled." (PIETERSE, 2010:84)

Como afirmamos acima, a partir da incorporação das diretrizes neoliberais pelas agencias multilaterais e a consequente deterioração do quadro social nos países do sul global multiplicaram-se as críticas mais profundas ao projeto do desenvolvimento. Pieterse define Alternative to Development ou Post-Development como a busca por uma ruptura com os preceitos e valores que subjazem a narrativa e o projeto hegemônico do desenvolvimento. Nas palavras do autor:

Post-development is based on a paradox. While it is clearly part of the broad critical stream in development, it shows no regard for the progressive implications and dialectics of modernity, for democratization, soft power technologies, network structures, reflexivity. (PIETERSE 1998:365)

A conclusão de Gustavo Esteva ao verbete desenvolvimento publicado no dicionário critico de desenvolvimento de Wolfgang Sachs exemplifica a posição que Pieterse descreve na citação acima:

"Development has evaporated. The metaphor opened up a field of knowledge and for a while gave scientists something to believe in. After some decades, it is clear that this field of knowledge is a mined, unexplorable land. Neither in nature nor in society does there exist an evolution that imposes transformation towards 'ever more perfect forms' as a law. Reality is open to surprise. Modern man has failed in his effort to be god." (ESTEVA, 2010:20)

Esta perspectiva teórica radical não está desprovida de mérito teórico e ideológico mas ainda tem reflexo imperceptível nas ações dos Estados Nacionais Periféricos e nas agências multilaterais que continuam a promover políticas de desenvolvimento.

A visão defendida nesta tese, propõem uma análise espacializada do desenvolvimento em que percebe este fenômeno como: a) uma difusão concentrada e hegemonizante de uma narrativa para a transformação do sul global baseada nos valores do norte e b) que é melhor representado por meio em uma imagem do espaço global dividido em centro e periferia. Tal perspectiva se enquadra nesta crítica radical a narrativa linear e tempocêntrica característica do discurso proferida pelas agencias internacionais de desenvolvimento. 
Conclusão. 
Em busca do ponto final

Esta tese procurou entrecruzar dois caminhos. Por um lado, foi realizada uma investigação que sobre o cenário que levou a constituição das políticas de transferência condicional de renda na América Latina voltadas ao combate a pobreza. O sucesso de programas como o Bolsa Família e o Oportunidades, principais resultantes deste processo, fez com que estas tecnologias sociais passassem a ser difundidas tanto por agentes vinculados ao norte hegemônico quanto pelos canais de diálogo sul-sul.

Mostramos ao longo da tese que este modelo de proteção social teve como origem a agência do Banco Mundial ao longo da década de 1990 e que desde então passaram a se difundir pela assemblage (Law, 2004) do desenvolvimento. Tal disseminação foi possibilitada, entre outros fatores, pelas relações assimétricas estabelecidas entre os actantes do norte e do sul global. Por esta desigualdade, classificamos este fluxo como concentrado (Ribeiro, 2013) e hegemonizante (Santos, 2006 e Ceceña).

A promoção do modelo de proteção social, baseado em políticas de safetynets e springboards para os países do sul global constitui uma evidência da aproximação entre o projeto hegemônico do desenvolvimento e os temas sociais. Tal incorporação é parte do processo de ampliação da agenda desenvolvimentista das agencias multilaterais.

No berço do projeto de projeto hegemônico de desenvolvimento em Breton Woods, o progresso das ex-colônias era definido de forma restrita e abarcava somente o crescimento do PIB e o investimento em obras de infraestrutura para a produção e exportação de produtos primários. Desde então, a agenda das agência ligadas ao norte global, representadas neste trabalho pela agencia do Banco Mundial, se ampliou até a incorporação de um modelo de proteção social.

Este último capítulo da expansão da agenda desenvolvimentista do norte, se concretizou a partir das crises econômicas ocasionadas pela implementação dos ajustes estruturais ao longo do auge da hegemonia neoliberal. Os principais atingidos por tais instabilidades foram as populações de baixa renda e alta vulnerabilidade das nações do sul global. E, diante deste quadro, o Banco Mundial passou a defender a criação de redes de segurança nacionais para proteger a população de baixa renda. 
Desde então, os países do sul global passaram a implementar políticas de alívio emergencial as populações economicamente vulneráveis e, a partir dos anos 1990, os primeiros formatos de transferências diretas de renda, adaptados as demandas do modelo de proteção social promovido pelo Banco Mundial, começaram a ser testados por todo o mundo.

Apesar de considerarmos este fluxo de disseminação de safetynets como hegemonizante, por ser imposto com base em relações assimétricas, os países atingidos pelos mesmo não podem ser vistos como meros receptores passivos do receituário do norte global. A diversidade de programas, formatos e aplicações as quais as transferências diretas de renda foram destinadas são evidência de que os agentes do sul global são mediadores (Latour, 2005) da chegada destes fluxos a suas realidades locais.

Entre estas experiências, uma passou a se destacar por sua singularidade. Trata-se do que chamamos aqui de modelo latino americano de transferências condicionais de renda. $\mathrm{O}$ programa Oportunidades do México e o Bolsa Família do Brasil são os principais casos de sucesso dessa política.

As TDCRs são resultado de uma incorporação mediada do modelo de proteção social promovido desde o norte global pelo Estado Brasileiro. Ou seja, este caso pode ser percebido como uma evidência da influencia que agentes do sul global podem exercer sobre as demandas dos actantes do projeto hegemônico.

O Bolsa Família, assim como o programa Oportunidades, são políticas que expandem os objetivos defendido pelo Banco Mundial que eram limitados ao alívio de vulnerabilidades transitórias. Em particular, este modelo latino americano de combate a pobreza, incorpora metas de longo prazo as transferências diretas de renda pela exigência de condicionalidades aos beneficiários dos programas. Estas contrapartidas visam investir em capacidades e capital humano das famílias pobres com o objetivo de promover a quebra dos ciclos geracionais de pobreza.

Este caso evidencia que os actantes do sul global se constituem como mediadores (Latour, 2005) dos fluxos que se propagam pela assemblage do desenvolvimento. Como descrevemos ao longo dos capítulos desta tese, o impacto da mediação exercida por Brasil e México vai além de impor tais singularidades as safetynets. A partir do ano de 2003, o Banco Mundial incorporou o modelo latino americano de TDCR à própria agenda social 
da instituição e passa a promover esta estratégia entre os países clientes do Banco sob a denominação de springboard.

Tal incorporação serve como exemplo da possibilidade de se formarem fluxos de diferentes tipos pela assemblage do desenvolvimento. Neste caso, trata-se de uma difusão que entendemos ter sentido sul-norte, ou seja, o sucesso atingido por Brasil e México na redução dos índices de pobreza em suas respectivas populações, levou a adoção deste modelo de política social pelos actantes do projeto hegemônico do desenvolvimento.

Este fluxo sul-norte, no entanto, não tem caráter hegemonizante pois não está embasado em relações assimétricas e nem promove valores societais do sul global a serem incorporados no norte desenvolvido. Pelo contrário, trata-se de um fluxo de caráter hegemonizado, pois, de forma geral, os países latino americanos se confinam aos ditames estabelecidos inicialmente pelo Banco Mundial. Em termos práticos, estas estratégias mantém o princípio da focalização, não interferem nos sistemas produtivos e nem procuram se constituir como direitos econômicos universais como são as Garantias de Renda Mínima nos países europeus. Os aprimoramentos feitos ao modelo de política pública das safetynets não representam uma quebra ou confronto de caráter radical ao paradigma dominante.

O resultado deste cenário é que tanto o o Banco Mundial quanto os países latino americanos passam a atuar na difusão deste modelo de proteção social. Esta disseminação ocorre tanto por meio dos canais norte-sul quanto sul-sul de cooperação para o desenvolvimento.

A pesquisa se voltou então para a implementação das TDRs na Índia. Assim como no caso brasileiro, o Estado Índia tem posição mediadora diante dos modelos que se difundem hoje pela matriz do desenvolvimento. São múltiplos os efeitos e que a implementação das transferências diretas de renda tem sobre a ação governamental para com a pobreza.

Nos detivemos primeiramente a mudança que foram impostas ao critérios de cálculo da linha nacional de pobreza. Neste processo, a fome que figurou como principal base para a determinação da pobreza desde a independência, perde seu protagonismo e a renda passa a ser o fundamento mais importante.

Desde a década de 70, quando o cálculo da linha nacional de pobreza foi instituído pela Indian Planing Comission, a base de referência era consumo calórico diário e diferenciado 
para populações rural e urbana. A partir de 2003, quando a renda é assume a centralidade para a definição da pobreza é adotado um formato em sintonia com a metodologia adotada pelas agencia multilaterais de desenvolvimento.

Por outro lado, evidenciamos que, apesar do discurso oficial do Estado Indiano se referir constantemente ao sucesso do modelo latino americano, a estratégia adotada pelo governo é de implementar programas de transferência direta incondicionais de renda em substituição as políticas tradicionais de subsídios e de distribuição pública de alimentos. A não adoção de modelos semelhantes ao Bolsa Família e Oportunidades é justificada pela a ausência de uma estrutura de serviços públicos para atender qualquer aumento de demanda.

A implementação das TDIRs na Índia são prioritariamente uma tentativa de diminuir o volume de gastos públicos com o sistema nacional de proteção social, mudança que é justificada pela percepção de ineficiência das políticas em vigor. Este discurso evidencia mais uma vez o processo paulatino de incorporação na Índia do modelo de gestão estatal defendido pelo Banco Mundial desde os ajustes estruturais. Portanto, ações interferir e regular o sistema produtivo da lugar programas focados exclusivamente a suplementação da renda das famílias em condição de vulnerabilidade.

Este cenário descrito a partir da investigação realizada no Brasil e na Índia é parte de um fenômeno mais amplo que denominamos de projeto hegemônico do desenvolvimento. A difusão das políticas de transferência de renda e do próprio modelo de proteção social em que estas se encaixam, faz parte de um conjunto extenso de transformações impulsionadas pelas agencias multilaterais em direção ao sul global. Tal perspectiva nos levou a estabelecer uma discussão sobre tal fenômeno e base do segundo caminho trilhado por este trabalho.

O segundo eixo, de caráter conceitual/metodológico, busca discutir uma aproximação crítica ao desenvolvimento ao discurso hegemônico. Em especial, procuramos debater ao longo da tese, a centralidade epistemológica da categoria tempo neste discurso.

O desenvolvimento, em sua versão hegemônica, é um projeto consciente e coordenado de transformações que se difunde do norte ao sul global. Tais movimentos são promovidos por agentes institucionais que sintetizam valores, ideologias e utopias do modelo societal do norte capitalista em um conjunto de direcionamentos concretos aos países da periferia 
do sistema mundo. Esta difusão é fundamentada nas relações assimétricas estabelecidas entre o norte e o sul global. Sintetizamos este conjunto de características sob a ideia de projeto hegemônico de desenvolvimento.

A narrativa que acompanha o projeto hegemônico de desenvolvimento e seu esforço de transformação do sul desde o norte, promove um padrão de progresso linear que tenta universalizar uma versão etnocêntrica da história econômica dos países capitalistas hegemônicos. O discurso de instituições como o Banco Mundial definem uma cartografia em que os povos que se encontram para além das fronteiras do centro étnico do sistema mundo atual são classificadas como em condição de atraso no suposto caminho universal do progresso.

O discurso do desenvolvimento é estruturado em forma de narrativa histórica. Esta forma de relato favorece: a) a geração de uma imagem sequencial e linear da história, b) a submissão do passado aos ditames do presente e atribuição de sentido e coerência ao movimento histórico universal pregado pelos agentes do projeto hegemônico do desenvolvimento.

Esta maneira unilinear de descrever o progresso histórico é também um sistema de classificação das diferenças dos territórios do sul global baseado na lógica universalista do desenvolvimento. Por tal procedimento, os países podem se posicionados, a partir de indicadores generalizantes, em condição de maior ou menor avanço na linha temporal do progresso universal.

É justamente sobre a crítica do discurso hegemônico do desenvolvimento que se estrutura a proposta metodológica desta tese, pela qual se buscou romper com a centralidade da categoria tempo, característica do discurso das agencias multilaterais de desenvolvimento. A abordagem adotada, procurou dar centralidade a três aspectos: a) a configuração do desenvolvimento como uma assemblage de actantes que formam o espaço de experiência contemporâneo, b) aos diferentes fluxos que trafegam pela matriz de agentes e territórios e, por fim, c) nos agentes promotores e mediadores destes fluxos.

Esta forma de cartografar procura dar protagonismo ao espaço como categoria de análise. O desenvolvimento é abordado como um fenômeno que ocorre no espaço global, platô onde a história está concentrada de maneira não sequencial e onde as relações desiguais os actantes se realiza. 
De forma a concluir o texto retorno a um dos pontos iniciais propostos na introdução desta tese. Naquele momento citei a intensificação do diálogo sul-sul como um dos pontos inspiradores desta pesquisa. Os professores Armando Barrientos e David Hulme da Universidade de Manchester afirmam no livro "Just Give Money to the Poor" que as Transferências de Renda constituem uma revolução vinda do sul. Como denota a citação abaixo, os autores se referem as TDR como uma alternativa de sucesso aos modelos de desenvolvimento vindos do norte:

Cash transfer programs are already being introduced across the South, as an explicit alternative to the development model promoted by the rich countries and their institutions. These programs work, and many southern governments see cash transfers as the front line in their battle against poverty and their efforts to promote development. (Hanlon et All, 2010:12)

Boaventura de Souza Santos, por outro lado, afirma que na contemporaneidade ocorre um fortalecimento do sul global como lócus de enunciação de conhecimento. A crescente importância do saber periférico foi precipitado pelo esgotamento do modelo epistêmico do norte (Boaventura, 2013).

Segundo o sociólogo português, a ascensão do saber periférico ou epistemologia do sul, desafia a verticalidade do diálogo norte sul e a folclorização dos conhecimentos locais. $\mathrm{O}$ autor chama de ecologia de saberes ${ }^{54}$ o ambiente horizontalizado entre os conhecimentos, necessários para romper o esgotamento da hegemonia epistêmica do norte.

O caso estudado nesta tese não se enquadra completamente nem na descrição Barrientos e Hulme, nem na de Boaventura. O cenário atual de difusão das transferências diretas de renda como parte do sistema de proteção social fornece indícios que a capacidade mediadora de parte dos actantes do sul global tem hoje maior latitude. Os impactos e ações que Brasil e México tiveram sobre o Banco Mundial e o papel que estas nações exercem

\footnotetext{
${ }^{54}$ La ecología de los saberes. No se trata de "descredibilizar" las ciencias ni de un fundamentalismo esencialista "anti-ciencia"; nosotros, como científicos sociales, no podemos hacer eso. Lo que vamos a intentar hacer es un uso contra hegemónico de la ciencia hegemónica. O sea, la posibilidad de que la ciencia entre no como monocultura sino como parte de una ecología más amplia de saberes, donde el saber científico pueda dialogar con el saber laico, con el saber popular, con el saber de los indígenas, con el saber de las poblaciones urbanas marginales, con el saber campesino. Esto no significa que todo vale lo mismo. Lo discutiremos con el tiempo. Estamos en contra de las jerarquías abstractas de conocimientos, de las monoculturas que dicen, por principio, "la ciencia es la única, no hay otros saberes". (SANTOS 2009a:21)
} 
na difusão de suas estratégias de combate a pobreza, são evidência de um maior protagonismos das mesmas na assemblage do desenvolvimento.

No entanto, quando nos restringimos ao caso das TDRs, o sul global não pode ser percebido um rompimento profundo com a assimetria que marca a configuração do espaço e das relações globais como parecem indicar Barrientos e Boaventura. O cenário levantado por esta pesquisa, demonstra um quadro complexo em que a separação entre os interesses e ações dos actantes sul e norte global não se faz clara.

Assim, compreendemos que, ao menos no caso das Transferências Diretas de Renda, reside na capacidade aumentada de mediação dos actantes submetidos aos fluxos hegemonizantes do norte, o principal indício de uma emergência do sul global. A capacidade de gerar fluxos de transformação que impactem mais profunda e radicalmente na ordem econômica e epistemológica do espaço global não descreve o caso aqui abordado, o que nos afasta tanto da perspectiva de Hulme e Barrientos quanto de Boaventura.

Como afirma Milton Santos (2006), o espaço global é formado de fluxos de diversas ordens e sentidos. Esta imagem, sintonizada com o estudo realizado, nos leva a entender que está na qualidade das relações que os actantes do sul global estabelecer com os movimentos vindos onde se denota as principais mudanças nas assimetrias e hegemonias que caracterizam o espaço global contemporâneo. 


\section{Pósfácio - Narrativa e Desenvolvimento.}

\section{Narrativas e ruinas.}

Desenvolvimento é o conceito central do projeto de transformação dos espaços periféricos promovido por agentes institucionais alinhados ao pensamento hegemônico do sistema mundo atual.

Como vimos acima actantes como o Banco Mundial são capazes de gerar um fluxos de mudanças que se difundem de norte ao sul do mapa geopolítico contemporâneo. Este movimentos de transformação originados das instituições do projeto hegemônico do desenvolvimento promovem uma narrativa sobre a qual se justifica e erguem suas ações.

O projeto societal da modernidade e o projeto hegemonico do desenvolvimento estabelece as fronteiras amplas e médias desta pesquisa. Como já apresentamos nos capítulos anteriores ambos comungam de uma visão unilinear de tempo baseado na utopia do progresso. Tais características nos levam a afirmar que tanto o desenvolvimento quanto a modernidade são uma narrativa histórica. O uso do termo narrativa é intencional pois tratase de uma forma de relato que a categoria tempo assume centralidade.

Neste último diálogo nos deteremos a uma discussão a respeito da narratividade histórica moderna, na qual buscaremos evidências desta centralidade epistemológica da categoria. A narrativa como instrumento é um fundamento epistemológico para a constituição da temporalidade linear e universalista sobre a qual se erguem a crença no progresso e a utopia emancipatória do projeto moderno.

Para atingir tal meta, procuramos estabelecer um diálogo com as obras de Giambattista Vico e Paul Ricouer. O pensador social napolitano fundador de disciplina de conhecimento sobre o social no entardecer da Renascença, se mostrou terreno fértil a percepção das narrativas como estratégia epistemológica moderna para a representação do social. Isso pois, a narrativa é para Vico o principal produto da ciência das nações e na qual se conecta tempo, ficção, poder e utopia. 
O diálogo com Vico, não é o único caminho que poderia fornecer tais evidências, no entanto, por sua vida transcorrer na alvorada da modernidade - dotando sua obra de localização histórica privilegiada - junto a importância do autor para o nascimento das ciências do social - justificam esta escolha.

Em seguida incorporaremos um diálogo com a obra de Paul Ricoeur, nos deteremos principalmente a suas ideias sobre o relato histórico, na qual o autor analisa a importância da narrativa como ferramenta epistemológica e a centralidade da categoria tempo. $\mathrm{O}$ autor também indica a importância da inclusão de elementos ficcionais que servem como conectores entre ruínas (evidências) do passado para a construção de narrativas e, ao mesmo tempo, se mostram fundamentais para a submissão o passado e o futuro aos ditames do presente. 


\section{Giambattista Vico e a Nuova Scientia}

O pensamento de Giambattista Vico (1668 - 1744) é de difícil classificação. Demonstra, em seu tempo, admiração tanto pela nascente ciência experimental moderna de Francis Bacon e Galileu Galilei, quanto pelas letras clássicas exaltadas pelo humanismo renascentista.

A produção intelectual do autor foi marcada profundamente pela Querelle des Ancient e des Modernes, embate referencial ao surgimento da ordem social moderna para os franceses. Os trechos abaixo, de Gillespie (2008) e Dalanty (2000), denotam a importância do evento tanto para a emergência da noção de progresso, quanto de uma nova consciência temporal:

The rise of a new science and the corresponding notion of progress in the context of an intellectual milieu dominated by an unrestrained admiration for antiquity led to the famous "querelle des anciens et des modernes" that captured the attention of French thinkers at the end of the seventeenth century. (Gillespie, 2008:5)

The idea of modernity found one of its first expressions in the seventeenth- and eighteenth-century debate between the 'ancients and the moderns', or the 'battle of the books', concerning literary style and the status of the classics, as represented in, for example, William Temple's Essay on Ancient and Modern Learning, published in 1690, and William Wotton's Reflections upon Ancient and Modern Learning, published in 1696.2 The moderns were those who had rejected classic style, such as the idea of timeless beauty or the reverence for the Augustan Age, in favor of the contemporary, which was characterized by a strong belief in science and progress. (Delanty, 2000:11)

Não se trata de evento limitado a França, se estende por todo o mundo europeu. No Reino Unido, o embate se reproduz pela "Battle of Books" e, na tradição alemã, se materializa no enfrentamento dos românticos com o elitismo francófono dos príncipes germânicos. (Delanty, 2000)

Embora boa parte dos escritos do pensador estejam voltados às questões da Querelle não é possível filia-lo totalmente a nenhum dos lados do debate. Levine resume o conteúdo do confronto da seguinte maneira:

It maybe useful to begin by distinguishing in the Quarrel two different areas of conflict. In the first place, there was an argument 
over knowledge that involved, in particular philosophy and natural science: did the ancients know more than the moderns in these matters? In the second place, there was an argument over literature and the arts: had the ancients achieved more than the moderns in these fields? For the first, the question involved accumulation for the second, imitation. (Levine 1991:56)

A nascente ordem moderna se dissemina pelo espaço de experiência europeu implementando, entre muitas outras coisas, uma nova forma de construção de conhecimento. Uma dos principais avanços sobre a antiga ordem medieval se dá pela ciência experimental sobre a hegemonia societal teocrática.

Durante a Querelle, os modernos de então desfilam em público um inédito e despudorado orgulho pelo novo e o desafeto pelo considerado antigo e superado. Propagam, junto ao seu pendor a uma nova literatura e a superação das visões renascentistas, uma nova abordagem ao mundo da natureza carregada de uma perspectiva epistemológica original que será central à ordem societal nascente. Durante a Querelle, será a literatura moderna, liberta dos cânones da poesia clássica, que abre caminho para os demais aspectos do pensamento moderno. Neste cenário de transformações, aberto e incerto, Vico lança a Nuova Scientia ampliando as questões da Querelle ao até o mundo do social.

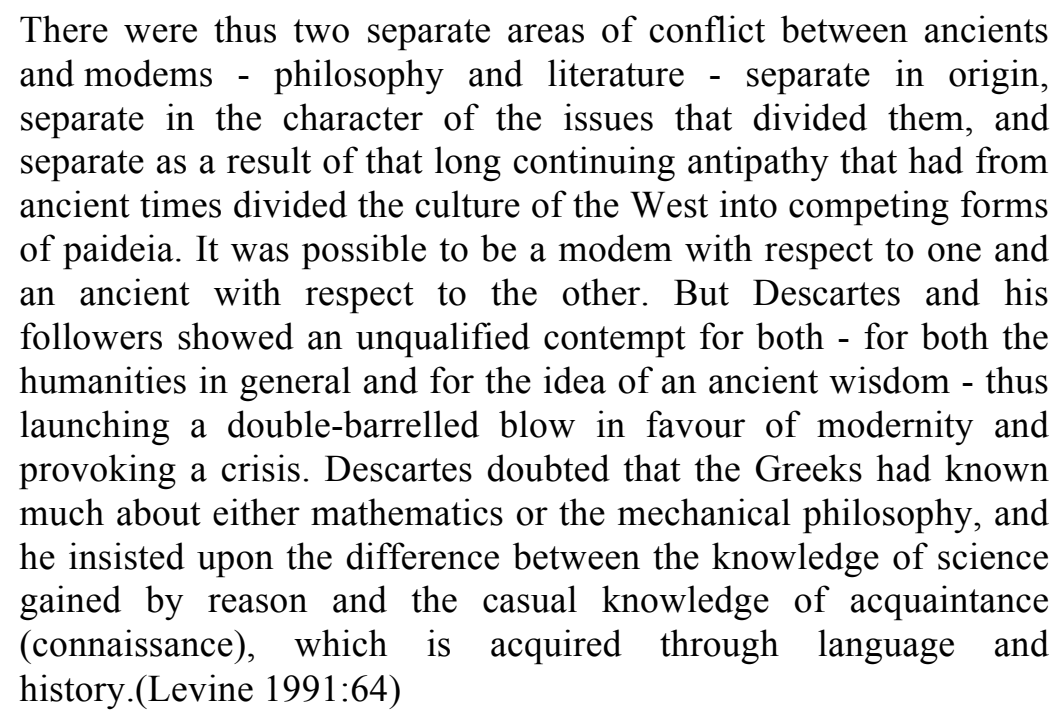

Os campos da filosofia e da arte citados por Levine, não recebem de Vico o tratamento uniforme do pensamento cartesiano. Em sua abordagem às ciências da natureza, o pensamento de Vico se aproxima dos modernos por sua exaltação ao método experimental. Já a sua postura diante das humanidades constitui-se pelo balanço entre a admiração renascentista pelo mundo clássico e a crença moderna na ciência experimental. 
Vico divide os campos de conhecimento em engenho e tópico. O saber das ciências naturais é chamado por ele de engenho, contraposto ao saber tópico da nova ciência do social que ele procura fundar. Ambos se erguem sobre o mesmo fundamento epistemológico de que o conhecimento só é possível aos criadores, ocorrendo na relação entre fato e feito.

Segundo Turner and Risjord (2007), o pensador napolitano antecipa-se a sistematização da hermenêutica do século XIX. Para ele, o saber se constrói a partir da ideia de que o compreensível se restringe ao feito. O conhecimento possível aos não-criadores será sempre incompleto.

The systematization of hermeneutics occurred largely in Germanspeaking Europe in the course of the nineteenth century, though this was substantially anticipated by Giambattista Vico (16881744), who formulated the basic principle that our knowledge of what we ourselves have made (individually or collectively) is different from what we have not made. The world of human society and culture is in some sense 'our' product, whereas the natural world is God's product.(Turner and Risjord 2007:459/460)

Apesar de assentadas sobre um princípio comum, os conhecimentos tópico e engenho se dividem em termos metodológicos, uma vez que as ciências da natureza se voltam aos feitos de Deus, e as do social debruçam-se sobre criações humanas.

De imediato, pelo princípio adotado pelo autor, estaria relegado a Deus a possibilidade de conhecimento pleno das coisas do mundo natural. Assim, Vico confronta o princípio epistemológico cartesiano pelo qual o mundo natural seria alcançável por meio da matemática.

Inspirado por Galileu e Bacon, Vico enxerga no recurso do experimento, a melhor via de aproximação epistemológica aos fenômenos naturais: é preciso reproduzir (re-fazer) para saber. (Hobbs 2002).

Sua posição sobre a Nova Ciência do social, no entanto, está carregada de ineditismo e o afasta de ambos os grupos envolvidos na Querelle. O mundo das nações, objeto da Nova Ciência, por se tratar de uma criação humana é plenamente cognoscível.

For the first indubitable principle above posited [331] is that this world of nations has certainly been made by men, and its guise must therefore be found within the modifications of our own human mind. And history cannot be more certain than when he who creates the things also describes them.(Vico 1948:93) 
Vico propõe como abordagem investigativa à sua nova ciência o retorno aos clássicos e relatos mitológicos, como fontes de evidência sobre os mundos passados. No entanto, não se trata de uma aproximação a posição do humanismo renascentista, atribuidor de superioridade e autoridade às obras clássicas em detrimento das modernas. O pensador napolitano sugere um olhar "antropológico" sobre as palavras e narrativas antigas em busca de indícios arqueológicos da verdade. O caminho para o conhecimento social está no dito.

The ability of humans to recollect and construct becomes the determining principle in the new division - or rather unification of knowledge, with the reader's own narration of human history or demonstration of it - raised to the rank of most certain. This may be Vico's parallel to the Baconian recognition that writing - literate experience - is the foundation for science. (Hobbs 2002:96)

A palavra é a principal evidência histórica à ciência das nações. A narração humana (experiência literária) equivale, no pensamento do autor, à experiência nas ciências da natureza. Vico atribui força de verdade ao mito, a literatura e aos relatos antigos de qualquer origem. Em outras palavras, o mundo das Nações é construído e narrado pelos homens e sua exploração se realiza pelas próprias palavras dos homens. De maneira circular, o conhecimento sobre as nações será reconstituído (re-feito) em narrativa e palavra.

\begin{abstract}
These philological proofs enable us to see in fact the things we have meditated in idea concerning this world of nations, in accordance with Bacon's method of philosophizing, which is "think [and] see" (cogitare videre). Thus it is that with the help of the preceding philosophical proofs, the philological proofs which follow both confirm their own authority by reason and at the same time confirm reason by their authority. (Hobbs 2002:94)
\end{abstract}

A filologia e a etimologia estão no centro da epistemologia de Vico. Estratégia que até hoje ronda as ciências do social e não são poucos os autores contemporâneos que iniciam suas obras sobre a modernidade por esta estratégia. (Habermas, 1981; Gillespie, 2008).

O fazer histórico é voltado à construção de narrativas, erguida sobre a seleção e união das ruínas deste passado. No caso do mundo das nações, as evidências (ruínas) são as palavras registradas e mantidas pelo vigor do senso comum, que as atribui de força de verdade (Hughes 1977). 
De volta a Vico, sua estratégia metodológica de crença nos mitos e histórias como indicativos dos mundos passados, não significa incorporar tudo o que está descrito nos mesmos, como afirma Mali:

Vico "did not so much believe tradition, as he believed in tradition; that is, although he accepted in principle the Catholic idea of tradition as a medium-of-truth he did not think that everything taught by tradition was true. Rather, like some enlightened (and quite unorthodox) Catholic thinkers in his time - Simon, Mabillon, or Montfaucon - Vico held'to 'tradition' but was not a 'traditionalist', if by that term we mean a servile follower of past authorities". (Mali 1992:225)

Trata-se de uma perspectiva singular de crítica, oposta ao pensamento moderno emergente em sua época de vida. Para autores como Bayle e Descartes, defensores radicais da perspectiva moderna, crítica significava a busca da verdade pela razão matemática e exposição dos erros e inverdades dos mitos e da literatura - uma filosofia negativa na visão de Vico.

The most forceful exponent of this view was Pierre Bayle. In his Critical-Historical Dictionary he states that because 'truth' is 'the soul of history, it is an essential thing for a historical composition to be free from lies; so that though it should have all other perfections, it will not be history, but a mere fable or romance, if it want truth'.(Mali 1992:216)

Para o pensador napolitano, a ideia de crítica (Ars Critica) denota seleção. Cabe ao analista moderno selecionar os indícios relevantes do passado inscritos nas narrativas da antiguidade para, sobre estas, erguer o novo conhecimento. Como as ruínas arqueológicas, evidências de outra etapa da história humana é preciso adentrar os textos do passado e encontrar as ruínas das antigas nações.

The duty of 'historical criticism', as Vico would ultimately conclude, is not to judge tradition as false just because it offends our standards of veracity, rationality, beauty, and so forth; rather, it must be an effort to understand and interpret its truth in and on the terms of those who wrote it, to grasp its common sense. By means of this new, so-called positive or redemptive 'art', in which we are called upon to appreciate historical traditions as 'truthful', even though and especially when they strike our modern sensibilities as being 'vulgar' - Vico believed to have overcome what he regarded as the negative kind of historical criticism, namely, the CartesianEnlightenment exercise in pure intellectual judgment of these and any traditions.(Mali 1992:218) 
Sua teoria do conhecimento não se limita aos ditames da razão experimental Baconiana, nem ao criticismo histórico, mas aproxima-se da produção artística tanto como fonte de evidências, quanto produto final de qualquer investigação sobre o mundo das nações. Isso pois, para Vico, o resultado último da pesquisa social é também uma criação literária: uma narrativa sobre a verdade (Verum Factum). Portanto, tarefa da nova ciência é, ao mesmo tempo, prospectiva (Ars Tópica), critica (Ars Critica) e criativa (Ars Ingenium).

O fundamento epistemológico da Nova Ciência é circular: parte do princípio de que o saber é possível aos criadores - o mundo das nações é criado pelo homem e então cognoscível - e, chega a uma criação - uma narrativa histórica sobre o mundo. Vico afirma, em última instância, que o mundo das nações e a sua narração são inseparáveis. Criam-se e recriam-se, mutuamente.

Ingenium, then, is both the origin and the result of the exercise of the ars inveniendi. The appropriation of the traditional category and the critique of Cartesian rationalism are simultaneous. When Vico says that the geometrical method cannot be applied to practical life, unless we pretend that "desire, rashness, occasion, and fortune do not rule in human things, so that you could draw a straight line through the curves of life" (A 7.5), he is underscoring the contrast between "method" and ingenium. (Miner, 1998:71)

No círculo epistemológico de Vico a Ars Ingenium - o produto narrativo da nova ciência é dependente tanto da Ars Tópica, quanto da Ars Critica. A primeira busca nas palavras e textos indícios de compreensão dos mundos passados, enquanto a segunda tem como papel selecionar e interpretar entre as ruinas descobertas.

Both topica and critica are required for ingenium. The ars topica provides comprehension, and the ars critica supplies focus. "Topics discovers things and piles them up. Criticism divides the pile and removes some of it: and thus the topical wits are more fertile, but less true; the critical ones are truer, but are sterile" (Secondariposta4). (Miner 1998:70)

Outro aspecto importante que deriva desta estratégia é a atribuição de autoridade epistêmica ao presente sobre o passado. Será a perspectiva moderna que concentrará o poder de filtrar o verossímil do inverossímil. O domínio do presente sobre o passado se reforça ainda mais, uma vez que será sobre o olhar moderno que constituirá a narrativa histórica - Ars Ingenium. Como afirmam tanto Mali (1992) e Miner (1998) 
"I regard this assertion - that modern society largely consists in, and must be interpreted through, its myth-historical poetics - to be Vico's most important contribution to the modern science of politics". (Mali 1992:259)

Verum-factum however, embraces not only the origination of elements, but also - and more directly - their arrangement for composition. Moral philosophy, despite its lack of formal certainty, does not constitute an exception to the general principle "to know is to compose [componere] the elements of things"(A 1.1). The knowledge proper to ethical praxis will as - sums the form of a collection of elements. It can therefore be described without violence as a type of "construction" even thoughts elements are not humanly produced (Miner 1998:78)

Vico não se limita a um discurso sobre o passado, pretende também uma ciência do hoje, do presente. A percepção do mundo atual ocorre pela conexão com o passado estabelecido pela narrativa histórica. Trata-se de uma ferramenta epistemológica poderosa constituída a partir das ruínas do passado de maneira a conectá-lo a vida atual e, ao mesmo tempo, fornece sentido histórico ao presente.

A narrativa gera uma visão ampla e coerente da história erguida sobre os interesses do analista moderno. Essa coerência incorpora dois atos criativos: o preenchimento das lacunas entre as ruínas encontradas e a elaboração de formatos gerais ao processo histórico.

A narrativa histórica dota o mundo das nações de temporalidade. A continuidade, duração e processo organizam o conhecimento sobre o mundo com base no tempo. Essa forma de relato ainda possibilita mais uma ação criativa, extensões utópicas rumo ao futuro.

As ciências do social, ao manterem a centralidade da narrativa histórica e sua epistemologia de temporalização do mundo, se permite construir imagens tanto de movimentos históricos como de futuro. Abrimos caminho, assim, para aprofundar esta perspectiva em diálogo com o linguista e filósofo francês Paul Ricoeur (1913 - 2005).

Mi tesis es que el vínculo de la historia con el relato no puede romperse sin que la historia pierda su especificidad entre las ciencias humanas. (Ricoeur 2000:193)

Ricouer, autor de extensa obra sobre narrativa e tempo, reafirma a centralidade epistêmica da narrativa - cuja temporalidade é marcada pela duração e continuidade - como formato fundamental de relato histórico. 
O caráter fragmentário das cronologias antigas e a simultaneidade entre passado e o futuro em um eterno presente não podem fundamentar a História. É a narrativa a forma de relato que ira conferir possibilidade de uma história moderna.

Ricoeur argues that the relationship between time and narrative both narrative history and narrative fiction-is of a kind that will not permit the type of hierarchization of text over context, or vice versa(...) (Grethlein 2010:314)

Kaplan (2003), ao analisar o pensamento de Ricoeur, afirma que para o autor a narrativa dota o mundo de ordem baseada na sucessão e continuidade entre eventos. Estes se colocam entre um inicio e um fim, forma-se então uma linha temporal que atribui, em última análise, sentido ao presente. Como mostra o trecho de seu pensamento:

Narratives establish the history of action by linking together a succession of events into meaningful episodes, understood from the perspective of an anticipated end. A narrative is like a long memory that orders and repeats sequences of events from beginning to end. With memory comes a retrieval of our past.(Kaplan 2003:56)

Para ser histórica, a narrativa deve obedecer uma prerrogativa: ser construída sobre as ruínas conhecidas do passado. Isso diferencia, em última análise, o ficcional do histórico. Assim como em Vico, isso não significa que não se mantenha um fundamento ficcional ao relato histórico, mas que este não deve ser preponderante. Para autores como Hayden White (White 1975), por exemplo, a verdade histórica é desafiada ao limite como narrativa ficcional.

Assim como White, Ricoeur reconhece que até mesmo os originais são, em alguma extensão, uma cópia ou até uma falsificação. Mas a busca por verdades últimas parece menos relevante diante da importância de constituir uma narrativa que tenha poder/autoridade de enunciar algo útil sobre o mundo do presente, dotando-o de sentido.

This does not mean that nothing is true but rather that the chief value of a historical account, as Paul Ricoeur argues in his great book Temps et recit, its power to tell us something worth knowing about our temporal world, is its ability to constitute a narrative.(Hughes and Trautmann 1995:275) 
A representação do passado e sua conexão com o presente, mesmo contendo características ficcionais, ainda se constitui como a melhor maneira pela qual as pessoas podem lidar com os horrores do passado recente.

\begin{abstract}
But, like White, Ricoeur wishes also to comment on historiography more generally. Scientific history provides no escape for the historian, who must represent the reality of the past by means of narrative, of story-telling. Ricoeur argues that in terms of representing the human condition, history is less effective than are fictional or other narratives. Although he does not question the historicity of history, he doubts its ability to 'actualize' events. The 'quasi-historical' world of fiction (particularly of historical fiction) may, therefore, present not just a different but a better means of dealing with the challenges posed to human beings by the passage of time than the 'quasi-fictive' world of history. Historical fiction becomes the best way in which people can resolve the problems posed by time, notably the problems of expressing the horrors of the recent past. (Mandelbrote 1996:340)
\end{abstract}

É a própria temporalidade, conexão coerente entre passado e presente, do relato histórico que confere verossimilhança ao discurso do historiador ou do etnógrafo, característica que estendo as demais ciências do social. Assim como na perspectiva do clássico napolitano, o linguista contemporâneo francês afirma que o mundo se ordena sobre a categoria tempo pela narrativa que é incorporada, apesar de seus aspectos ficcionais, a escrita científica.

Ricoeur calls temporality, "the structure of existence that reaches language as narrativity. This power to recount is reciprocally defined as "the language structure that has temporality as its ultimate referent." And this implies that the truth of historians and ethnographers depends upon a sense of time and duration quite different from that of a chronicler or archivist but similar to that of the novelist or dramatist. (Hughes and Trautmann 1995:276)

Para Ricoeur, a partir do pensamento de Martin Heiddegger, o tempo como categoria geral une o tempo fenomenológico - aquele percebido pela experiência humana - ao tempo cosmológico - as leitura objetivas da essência da natureza. No entanto, para o francês, é somente pela narrativa que se materializa a experiência do tempo humano, enquanto o filósofo Alemão se mantém em uma perspectiva puramente fenomenológica:

Paul Ricoeur's Time and Narrative (1984-88). In these three monumental volumes, Ricoeur tries to define time in terms of narrative. He argues that a pure phenomenology of time, such as that pursued by Edmund Husserl (1928) and Martin Heidegger (1988 [1927]), is bound to fail, because it cannot 
reconcile phenomenological and cosmological times. (Grethlein 2010:314)

A narrativa, de acordo com Kaplan, tem função de mediação entre a experiência temporal e a constituição de um tempo objetivo universal (e ficcional, na visão de Kapplan) sobre o qual história parece se erguer. Três conectores aparecem nas narrativas de forma a relacioná-las a experiência humana: o calendário - percepção do tempo pelos estágios e fases do mundo da natureza - as gerações - percepção de tempo biológico pelas relações de parentesco, e, por fim, os documentos - percepção de tempo por meio dos traços do passado.

Vico restringe os fundamentos epistemológicos ao terceiro conector, enquanto Ricoeur expande os fatores de composição da narrativa a outros aspectos da experiência temporal humana.

The mediation of time and narrative occurs through three "connectors."

The first connector is calendar time. Calendars, along with clocks and watches, join together astronomical time, tied to the rotation of the planet, with public, datable time. A calendar is both an astronomical and a social-political instrument. It unites workdays, holidays, significant events, and dates with seasons and years, integrating human time with cosmic time. "It cosmologizes lived time, it humanizes cosmic time" (TA 214). A second connector is the notion of a succession of generations, or a biological time that underlies human time. Be- longing to the same generation and the coexistence of different generations are ways that biological time marks and organizes lived time. A culture is linked together by the contemporaneity of predecessors, successors, and contemporaries. We are constantly reminded of our connection to the past through the presence of generations. The social bond is woven with a biological texture that assures a continuity of life among the living.

The third connector is the document, or the historian's evidence of the past. A trace of the past is a vestige left behind, a remnant, or relic that provides clues of what the past was like. A trace is a physical entity that exists in the present but refers to the past, which itself exists and persists through the trace. At the same time, a trace is only a trace for someone who knows how to read it as a sign of something absent. A trace is a present remnant of an absent past that simultaneously belongs to both the past and the present. (Kaplan 2003:57)

É justamente por estabelecer essas conexões entre a experiência humana objetiva e aspectos ficcionais, que a narrativa se torna o lócus para uma proposta de universal de 
tempo. A sobreposição de elementos de quase-ficção e quase-histórico fundamentam a construção de um tempo universal.

Historical narratives contain fictional elements whereby phenomenological time is inscribed in cosmological time. Simultaneously, cosmological time is inscribed in phenomenological time through historical elements that pervade fictional narratives: "The interweaving of history and fiction in the reconfiguration of time rests, in the final analysis, upon this reciprocal overlapping, the quasi-historical moment of fiction changing places with the quasi-fictive moment of history. (Grethlein 2010:314)

Para o pensador francês, o tempo só se torna significativo aos se transformar em narrativa. Ou seja, essa forma de relato é o instrumento epistemológico pelo qual o tempo se transforma em social e assume a forma de tempo humano.

Nessa percepção de um tempo socialmente relevante com pretensões universais, assim como no pensamento de Vico, unem-se de maneira ordenada a Ars Crítica e a Ars Tópica.

Time is meaningful only as human time, when it becomes refashioned and turned into the kind of public, social thing that can be understood when expressed in a fictional or historical narrative. (Kaplan 2003:56)

Dotar a história de sentido pela conexão entre passado e presente equivale a caracterizá-la como um processo (movimento). Pode-se ainda, pela utilização das narrativas como instrumento epistemológico, extrapolar em direção ao futuro unindo, nos termos de Ricoeur, Ideologia e Utopia.

No entanto, como afirma Mendelbrote, tanto nas conexões com o passado, quanto nas visões de futuro prevalecem as necessidades do presente.

Nevertheless, for Ricoeur and others, historical fiction represents a better understanding of the past than history, because it is more responsive to the needs of the present. (Mandelbrote 1996:341)

A teleologia que se ergue da união entre história e narrativa é central ao discurso do projeto contemporâneo de desenvolvimento. Neste, a história é dotada de ordem, sentido, movimento, e ainda fundamenta a visão sobre o futuro de acordo com as necessidades do presente. Será necessário, debate que enfrentaremos em outro momento deste texto, uma perspectiva menos homogeneizada de presente, o que faremos pela incorporação dos 
agentes sociais. Kaplan, na citação abaixo, detalha a relação entre ideologia e utopia da obra de Ricoeur:

But creative, narrative discourses are both the cure and the poison. As imaginative interpretations of the world that mediate understanding, they have the capacity to shape social relations for better or worse. Ideology and utopia, the pair Ricoeur insists remain together, are like other metaphoric and narrative discourse in that they project new ways of seeing and being in the world based on creative configurations of human action. Ideology and utopia are polar opposites of a single "cultural imagination" that mediates and integrates human action through interpretive schemas that both constitute and distort a society. It is the same symbolic structure that is prefigured in narrative discourse that also constitutes social life as the cultural imagination. "Unless social life has a symbolic structure, there is no way to understand how we live, do things, and project these activities in ideas, no way to understand how reality can become an idea or how real life can produce illusions" (IU 8). His thesis is that ideology and utopia are operative but never totally thematic; we think and act from them rather than about them. (Kaplan 2003:62)

Assim, de maneira sintética, as ruínas espalhadas, desconexas e desafiadoras do passado se transformam em literatura. Essa poesis histórica é construída com base nos interesses do presente e fundamenta uma visão do futuro. $\mathrm{O}$ mundo é transformado pela narrativa em uma experiência temporal.

The world unfolded by every narrative work is always a temporal world. Or, as will often be repeated in the course of this study: time becomes human time to the extent that it is organized after the manner of a narrative; narrative, in turn, is meaningful to the extent that it portrays the features of temporal experience.(Ricoeur 1984:4)

De acordo com Ricoeur, as narrativas são capazes de unir o caráter comum da experiência humana, o tempo. Ou seja, em um última análise, assim como em Heidegger, o tempo é uma categoria universal à existência humana. Não se nota no pensamento de ambos a dimensão espacial da existência. Nessa perspectiva, o tempo não se transforma de acordo com o espaço ou agentes sociais.

Mi hipótesis básica al respecto es la siguiente: el carácter común de la experiencia humana, señalado, articulado y aclarado por el acto de narrar en todas sus formas, es su carácter temporal. Todo lo que se cuenta sucede en el tiempo, arraiga en el mismo, se desarrolla temporalmente; y lo que se desarrolla en el tiempo puede narrarse. Incluso cabe la posibilidad de que todo proceso 
temporal sólo se reconozca como tal en la medida en que pueda narrar-se de un modo o de otro.(Ricoeur 2000:190)

É no pensamento de Martin Heiddeger que se origina esta perspectiva universalista e desenraizada de tempo adotada por Ricoeur. Em sua obra opõem-se Tempo Ordinário/Tempo Relógio - de-significado e comportando apenas a noção abstrata de sucessão - a Tempo Mundo - temporalidade ou tempo humano.

Heidegger atribui a própria percepção da existência a sucessão de eventos na vida e na história humana, tal a centralidade epistêmica dada ao tempo em sua filosofia.

A abordagem fenomenológica do autor alemão estabelece uma relação circular entre experiência temporal e a existência: O tempo Mundo é uma construção erguida a partir da experiência/existência humana e a própria existência só é percebida em termos temporais.

Essa ideia, como já foi discutido acima, será incorporada por Ricoeur e retirada de seu contexto fenomenológico original. Para o linguista francês, a união entre tempo fenomenológico (tempo Mundo, no pensamento de Heidegger) e cosmológico (tempo ordinário na conceituação Heideggeriana) só se realiza pela construção de narrativas.

Tanto a fenomenologia purista e abstrata de Heidegger, quanto a abordagem linguística de Ricoeur, apesar de suas diferenças, estão em sintonia na atribuição de caráter desterritorializado ao tempo. O tempo é relacionado a experiência humana, a qual podemos apenas inferir traços de espacialidade. Mais do que isso, a experiência humana, que ao mesmo tempo fundamenta e é fundamentada pelo tempo, aparenta ser composta por uma massa uniforme e indiferenciada de agentes.

A incorporação de uma dimensão espacial e de agentes sociais diversos a conceituação de experiência humana ameaça a linearidade e universalidade do tempo humano expresso nas narrativas.

Será Reinhart Koselleck, historiador alemão, um dos que procuram desenvolver a perspectiva de Heidegger, reformulando sua visão de experiência humana dotando-a de espacialidade. De acordo com Grethlein (2010), Koselleck passa a situar o tempo mundo na tensão entre o horizonte de expectativas - futuro; e o espaço da experiência - território.

Heidegger's focus on pro-tension has been adopted and freed from the gloomy tenor of Being and Time by Reinhart Koselleck (1985), who defines human time as the tension between the horizon of expectations (Erwartungshorizont) and the space of 
experiences (Erfahrungsraum). Guided by previous experiences, we direct expectations to the future: these are either fulfilled or disappointed by new experiences, which in turn not only form the background for new expectations but also retroactively transform the memory of previous expectations and experiences. While the relation between expectations and experiences differs from culture to culture, the very tension between them seems to have a transcendental character and to define human temporality. (Grethlein, 2010:316)

Para Koselleck, o espaço da experiência - que substitui a ideia ampla de experiência humana usada por Heidegger e Recoeur - condensa em um território o passado e presente - constituindo um platô. A experiência humana transcorre, portanto, entre diversas camadas de passado que convivem em um mesmo local. A conexão com o passado não se dá somente pela narrativa, ocorrendo também no espaço.

No entanto, na relação espacial com o passado não há indicação clara de sucessão. Serão as narrativas sobre a história que, em última análise, fornecerão ordem, conexão e importância a estes eventos condensados no espaço.

It makes sense to say that experience based on the past is spatial since it is assembled into a totality, within which many layers of earlier times are simultaneously present, without, however, providing any indication of the before and after. (Kosseleck, 2004:160)

O futuro, que nas narrativas é alcançado pela extensão da relação entre passado e presente, na visão espacializada de Kosseleck, ocorre de acordo com as expectativas de futuro que também se fundamentam no espaço. Assim, o tempo humano não é só perceptível pelas narrativas, como pensava Ricoeur, mas no encontro entre o espaço de experiência e o horizonte de expectativas. Pela visão do historiador alemão dota-se o tempo humano de especificidade e não universalidade.

No livro Futures Past, o historiador alemão atribui a modernidade a construção de um novo horizonte de expectativas. As imagens de constante repetição do passado tradicionais a Europa pré-moderna, muitas das quais apontavam um destino ritualisticamente catastrófico à humanidade, são abandonadas em virtude uma representação do processo histórico em que o passado e futuro quase nunca convergem.

Past and future never coincide, or just as little as an expectation in its entirety can be deduced from experience. 
O espaço de experiência, no entanto, não aglutina somente o passado e o presente em seu platô. São compostos por agentes sociais diversificados em uma matriz relações mútuas desiguais. Mais do que isso, cada um destes agentes estabelece conexões múltiplas com o passado e diferentes expectativas de futuro.

Milton Santos (2006), destaca em sua obra sobre tempo e espaço, escrita sob a ótica da geografia, que os diferentes agentes sociais geram temporalidades próprias. Essas perspectivas também se agregam ao espaço de experiência.

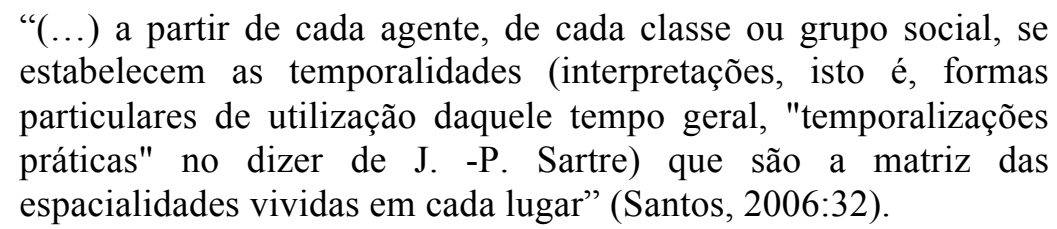

Ao perceber a experiência humana como dotada de espacialidade e de agentes sociais em constante relação, atribui-se menos centralidade epistêmica a categoria tempo e desafia-se tanto a sua universalidade quanto sua linearidade. Os tempos e futuros são tão diversos quanto os espaços de experiências e os agentes sociais que neles estabelecem suas relações.

O projeto do desenvolvimento, como veremos adiante, ainda exibe em seu discurso uma lógica narrativa. $\mathrm{O}$ passado se conecta ao presente em uma lógica linear, dotado de um processo universal de movimento e um futuro utópico comum. Submete todos os territórios a esta cartografia temporal, que ordena os espaços de acordo com o avanço no processo universal de progresso. Todos os países e povos estão atrelados a tempo único e universal.

Da exploração de caráter epistemológico das narrativas, por meio de Vico e Ricoeur, e à critica apresentada com base nos pensamentos de Koselleck e Santos, destacamos:

a) As narrativas conectam passado e presente de maneira coerente, o que significa dotar de temporalidade, duração e continuidade, a experiência humana. São três os conectores usados nas narrativas como forma de mediação com a realidade objetiva: biologia, calendário e documentos.

b) Os critérios sobre os quais se estabelece a coerência entre passado e presente são os aspectos ficcionais do relato histórico. As lacunas entre as ruínas do passado precisam ser preenchidas para que a narrativa tenha verossimilhança. 
c) Tanto a seleção das ruínas do passado, quanto o preenchimento das lacunas, ocorrem de acordo com os interesses dos agentes do presente.

d) Uma narrativa, por ser dotada de movimento e processo, também possibilita a incorporação de elementos ideológicos e utópicos. Assim, estende-se ao futuro.

e) As narrativas históricas assumem a existência de uma temporalidade comum a experiência humana. O tempo humano é universal.

f) As narrativas silenciam a dimensão espacial das temporalidades.

g) A experiência humana ocorre no espaço, onde se agrega o passado e o presente. É neste espaço que as expectativas de futuro se desenham.

h) A temporalidade está condicionada aos agentes sociais que compõem o espaço de experiência.

i) A narrativa ergue ao status de universal uma temporalidade que é construída em espaço de experiência e por agentes sociais específicos. 


\section{Bibliografia}

Almeida Filho, N. (2003). “O Desenvolvimento Da América Latina Na Perspectiva Da CEPAL Dos Anos 90: Correção de Rumos Ou Mudança de Concepção.” Liberalização econômica e desenvolvimento. São Paulo: 1-21.

Amin, Samir. (1989) Eurocentrism. New York: Monthly Review Press, 1989.

Amin, Samir. (1989b). El Eurocentrismo: Crítica de Una Ideologia. Siglo XXI Editores.

Amin, Samir. (2011). "Modernity and Religious Interpretations.” Pp. 1-36 in Philosophy and African Development: Theory and Practice, edited by Lansana Keita. Codesria.

Ansell, Aaron, and Ken Mitchell. (2011). "Models of Clientelism and Policy Change: The

Case of Conditional Cash Transfer Programmes in Mexico and Brazil.” Bulletin of Latin American Research 30(3):298-312.

ARBIX, G. (2002) Da liberalização cega dos anos 90 à construção estratégica do desenvolvimento. Tempo Social; Rev. Sociol. USP, S. Paulo, 14(1): 1-17, maio de 2002.

Azevedo e Burlandy, (2010) Política de combate à pobreza no Brasil, concepções e estratégias Rev. Katál. Florianópolis v. 13 n. 2 p. 201-209 jul./dez. 2010

Barrientos, A. (2010) Social Protection and Poverty. Social Policy and Development Programme Paper Number 42

Berman, M. (1986)Tudo que é Sólido desmancha no ar” São Paulo: Companhia das Letras. 1986

Berman, M. (2001) Aventuras no Marxismo São Paulo: Companhia das Letras, 2001

Bhambra, G. K. (2007). Rethinking Modernity. Basingstoke: Palgrave Macmillan.

Bhambra, G. K. (2010). "Historical Sociology, International Relations and Connected Histories." Cambridge Review of International Affairs 23(1):127-43.

Bhambra, GK. (2011). "Historical Sociology, Modernity, and Postcolonial Critique." The American Historical Review 3(3):313-16. 
Bielschowsky, R.(org.) (2000) Cinqüenta anos de Pensamento na CEPAL. Rio de Janeiro: Record, 2000.

Borgatti, S e Everett, M (1999) Models of core/periphery structures Social Networks 21 1999. 375-395

Bresser-Pereira, L. C. (2001). "Reforma Da Nova Gestão Pública: Agora Na Agenda Da América Latina, No Entanto.” International Journal of Political Studies (3):143-66.

Bresser-Pereira, L. C. (2005) Do ISEB e a CEPAL à Teoria da Dependência in: TOLEDO, C. N., org.(2005) Intelectuais e Política no Brasil: A Experiência do ISEB. São Paulo: Editora Revan: 201-232.

Bresser-Pereira, Luiz Carlos. (2005). "Do Iseb E Da CEPAL À Teoria Da Dependência." in Intelectuais e a Política no Brasil: A Experiencia do ISEB. Rio de Janeiro: Revan.

Burchardt, H. J. (2004). "El Nuevo Combate Internacional Contra La Pobreza: i Perspectivas Para América Latina?” Nueva Sociedad 119-32.

Busilacchi, G. (2010) The different regimes of minimum income policies in the enlarged Europe. BIEN Conference Dublin, $20^{\text {th }}-21^{\text {st }}$ June 2008

Bussolo, M. e Jeffery I. R. (2006). Globalisation and Poverty: Channels and Policy Responses. Routledge.

Calvo, C. (2011). "Social Work and Conditional Cash Transfers in Latin America.” J. Soc. \& Soc. Welfare XXXVIII(3):53-73..

Carneiro, R. (2002) Desenvolvimento em Crise: A Economia Brasileira no Último Quarto do Século XX. São Paulo: Editora Unesp, 2002.

Castro-Gómez, S. 1998. “Geografías Poscoloniales Y Translocalizaciones Narrativas de 'lo Latinoamericano.’’Pp. 155-82 in Enfoques sobre Posmodernidad en América Latina. Caracas: Editorial Sentido.

Castro-Gomez, S. e Grosfoguel. R. (2007). El Giro Decolonial:Reflexiones Para Una Diversidad Epistémica Más Alla Del Capitalismo Global. Siglo del Hobre Editores.

Castro-Gómez, S. et al. (2008). La Colonialidad Del Saber. edited by Edgardo Lander. CLACSO. Retrieved October 26, 2013.

Cecchini, C. (2011) Programas de transferencias condicionadas. Cepal.

Ceceña, A. E. (2004). Hegemonías Y Emancipaciones En El Siglo XXI. CLACSO. 
Ceceña, A. E. (2006). "Subjetivando El Objeto de Estudio, O de La Subversión Epistemológica Como Emancipación.” in Los Desafios de las Emancipaciones en un Contexto Militarizado. CLACSO.

Chandra, B., Muhkerjee M., e Muhkerjee, A (1999) India After Independence. Penguin Books India.

Chandrassekhar e Ghosh, 2002

Chatterjee, P. (2008) La nación en tiempo heterogéneo y otros estudios subalternos. Buenos Aires: Siglo XXI (CLACSO), 2008.

Chattterjee, P. (1997). Our Modernity. Codesria.

Chen, S e Ravallion, T (2008) The Developing World Is Poorer Than We Thought, But No Less Successful in the Fight against Poverty. World Bank

Cohn, A (1995) Políticas Sociais E Pobreza No Brasil. Planejamento de Políticas Públicas. Número 12 Jun/Dez

Cole, Julio H., (2008). "Milton Friedman on Income Inequality." Journal of Markets \& Morality 11(2):239-53.

Comaroff, J. e Comaroff, J. (2001). Millennial Capitalism and the Culture of Neoliberalism. Duke University Press.

Cotta, R e Machado, J (2013). Programa Bolsa Família e segurança alimentar e nutricional no Brasil: revisão crítica da literatura. Rev Panam Salud Publica 33(1), 2013

Cunha, R S/D. Programa Bolsa Família como estratégia para redução da pobreza e os processos de cooperação e coordenação intergovernamental para sua implementação. (Texto Interno do Ministério do Desenvolvimento Social e Combate a Fome).

Currie, Mark. (2007). About Time: Narrative, Fiction and Philosophy of Time. Edimburgh University Press.

D’Allonnes, M. R., e Azouvi, F. (2004). Paul Ricoeur. Editions de l'Herne.

D’Éntrèves, M. P, e Benhabib, S. (1996). Habermas and the Unfinished Project of Modernity. MIT Press.

DAFF. (2011) The Framework For The Zero Hunger Programme 
De La O, A. L. (2013). "Do Conditional Cash Transfers Affect Electoral Behavior? Evidence from a Randomized Experiment in Mexico." American Journal of Political Science 57(1):1-14.

Dean, M. (1994). Critical and Effective Histories: Foucault's Methods and Historical Sociology. Routledge.

Delanty, G. (2000). Modernity and Postmodernity. Sage.

Delanty, G. (2006). Handbook of Contemporary European Social Theory. Routledge.

Delanty, G. e Rumford, C. (2005). Rethinking Europe: Social Theory and the Implications of Europeanization. Routledge.

Domingues, J. M. (1998). “Desenvolvimento, Modernidade E Subjetividade.” Revista Brasileira de Ciências Sociais 14(40):83-91.

Domingues, J. M. (1998). Sociologia e Modernidade: para entender a sociedade contemporânea. Rio de Janeiro: Civilização Brasileira, 1999.

Domingues, José Mauricio. (2008). Latin America and Contemporary Modernity. Routledge.

Dreze, J. e Sen, A. (2007) The Political Economy of Hunger. Oxford University Press

Driusso, M. (2010). "Estudo Comparado Entre Os Programas de Transferência Condicionada de Renda No Brasil E México São Paulo.”

Dussel, E. (1996). The Underside of Modernity. Humanities Press..

Dussel, E. (2001) Eurocentrismo e Modernidad. In: Mignolo, W. (org) (2001) Capitalismo e Geopolítica do Conhecimento. Buenos Aires, Ediciones del Signo, 2001.

Edelman, M e Haugerud A. (Eds.) (2008) Anthopology of Development and Globalization. Blackwell Publishing, Maldin.

Escobar, A. (1991). "Anthropology and the Development Encounter: The Making and Marketing of Development Anthropology.” American Ethnologist 18(4):658-82.

Escobar, A. (1992) "Imagining a Post-Development Era? Critical Thought, Development and Social Movements.” Social Text 31-32, 1992

Escobar, Arturo. (2007). La Invension Del Tercer Mundo: Construcción Y Deconstruccion Del Desarrollo. Fundación Editorial el Perro y la Rana. 
Esteva, G. (2010) “Development.” In: SACHS, W. The Development Dictionary: A Guide to Knowledge as Power. Zed Books, New York, 2010

Fabian, J. (2002). Time and the Other: How Anthropology Makes Its Object. Columbia University Press.

Fernandes, F. (1968) Sociedade de Classes e Subdesenvolvimento. Rio de Janeiro: Zahar Editores.

Fried, B. J. (2012). "Distributive Politics and Conditional Cash Transfers: The Case of Brazil's Bolsa Família.” World Development 40(5):1042-53.

George, S. e Sabelli, F. (1994) Faith and Credit: The World Bank's Secular Empire. London: Penguin Books.

Geras, Norman, and Robert Wokler. (1999). The Enlightenment and Modernity. Palgrave Macmillan.

Ghosh J. e Chandrakkar, K. (2011) The Market that Failed. Left Word.

Ghosh, J. (2011) Cash Transfers as the Silver Bullet for Poverty Reduction: A Sceptical Note. Economic \& Political Weekly EPW may 21, 2011 vol xlvi no 21

Gillespie, M. (2008). The Theological Origins of Modernity. University of Chicago Press.

Gilman, J (2003) The Mandarins of the Future. The Johns Hopkins University Press

Giugliano, R. (2013). Brazil and India CCT programs: a view of poverty and policy from the south. Presented in Santiago de Chile September 2013.

Goonewardena, Kanishka, Stefan Kipfer, Richard Milgrom, and Chistian Schmid. (2008). Space, Difference, Everyday Life: Reading Henri Lefebvre. Routledge.

Grethlein, J. (2010). “The Narrative Reconfiguration of Time beyond Ricoeur.” Poetics Today 31(2):313-29.

Grosfoguel, R. e Cervantes-Rodrígues, J. eds. (2002). The Modern/ Colonial/ Capitalist World-System in the Twentieth Century. Greenwood Press.

Gross, David. (1992). The Past in Ruins: Tradition and the Critique of Modernity. University of Massachusetts Press.

Guignon, C. B. (1993). The Cambridge Companion to Heidegger. Cambridge University Press. 
Habermas, Jürgen. (1981). "Modernity versus Postmodernity." New German Critique (22):3-14.

Habermas, Jürgen. (1987). The Philosophical Discorse of Modernity. Polity Press.

HAGEN, E. O Processo de Mudança. Rio de Janeiro, Zahar: 1967. In: DURAND, José. Sociologia do Desenvolvimento. Rio de Janeiro, Zahar Editores: 1967.

Hammer, E. (2011) Philosophy And Temporality From Kant To Critical Theory

Hanlon, J Barrientos, A e Mulme, D (2010) Just Give Money to the Poor. Kumarian Press

Heeks, (2013) Actor-Network Theory for Development. Development Studies Research and Actor-Network Theory. Paper 1. http://www.cdi.manchester.ac.uk/resources/ant4d Heidegger, M. (1975). "Introduction.” in The Basic Problems of Phenomenology. Indiana University Press.

Heidegger, M. (n.d). "Martin Heidegger Rectoral Address." Review of Metaphysics (38):467-502.

Hetherington, K. (1997). No The Badlands of Modernity: Heterotopia and Social Ordering. Routledge.

Hettne, B. (2008) Development theory and the three worlds: towards an international political economy of development. Longman Scientific \& Technical

Hobbs, C. L. (2002). Rhetoric on the Margins of Modernity: Vico, Condillac, Monboddo. Southern Illinois University Press.

Hoff, K. e Stiglitz. J. (2001). “Modern Economic Theory and Development.” Frontiers of development economics 389-459.

Holub, R. (1992). Antonio Gramsci: Beyond Marxism and Postmodernism. Routledge.

Hopper, D. (1991) Technology, Teology and the Idea of Progress. Louisville: Westminster and John Knox press, 1991.

Howson, R. e Smith. K. (2008). Hegemony: Studies in Consensus and Coercion. Routledge.

Hughes, D. O., e Trautmann. T. R. (1995). Time: Histories and Ethnologies. edited by Diane Owen Hughes and Thomas Trautmann..

Hughes, P. (1977). "Restructuring Literary History: Implications for the Eighteenth Century." New Literary History 8(2):257-77. 
IPC. (2011) Interim Report of the Task Force on Direct Transfer of Subsidies on Kerosene, LPG and Fertiliser

IPC. (2012) Report on the Expert group Comission to Recomend Detailed Methodology for Identification of Poor Families.

Ipea (2010) Bolsa Família 2003-2010: avanços e desafios Vol 1. Série Desenvolvimento IPEA, (2012) A Década Inclusiva. Série Desenvolvimento

Jha, P. (2011). Progressive Fiscal Policy in India. Sage.

Jones, S. P. (2004) An End to Poverty? A Historical Debate. New York: Columbia University Press, 1998.

Joseph, C. A. B., e Wilson, J. (2006). Global Fissures: Postcolonial Fusions. Rodopi. Retrieved November 22, 2013.

Kant, I. 1784. "What Is Enlightenment?" On History. Retrieved February 10, 2014 (http://fairbanksonline.net/Fairbanks_Online/Reading_Assignments_files/Sherman Ch 8 The Enlightenment.pdf).

Kaplan, D. (2003). Ricoeur's Critical Theory. State University of New York Press.

Kapur, D. (2011) The Shift to Cash Transfers: Running Better But on the Wrong Road? may 21, 2011 vol xlvi no 21 EPW Economic \& Political Weekly

Kapur, D. Lewis. J. e Webb. R (1997) The World Bank: The First Half Century. New York Brookings Press.

Kiggundu, M. N. (2012). “Anti-Poverty and Progressive Social Change in Brazil: Lessons for Other Emerging Economies." International Review of Administrative Sciences 78(4):733-56.

Kohli, A. (1987) The State and Poverty in India Cambridge University Press.

Koselleck, R. (2000). Critique and Crisis: Enlightenment and the Pathogenesis of Modern Society Studies. MIT Press.

Koselleck, R. (2002). The Practice of Conceptual History: Timing History , Spacing Concepts. Stanford University Press.

Kosseleck, R. (2004) Past Futures. Columbia University Press

Kotwall et all, 2011 
Kotzé, H., e Schulein, S. (2013). "Linking Values and Development: An Empirical Analysis.” Pp. 133-58 in Values and Development in Southerns Africa. Codesria.

Krishna, S. (2009). Globalization and Postcolonialism: Hegemony and Resistance in the Twenty-First Century Globalization. Rowman \& Littlefield Publishers.

Kumara, A. S., e Pfau. W. D. (2011). "Impact of Cash Transfer Programmes on School Attendance and Child Poverty: An Ex Ante Simulation for Sri Lanka." Journal of Development Studies 47(11):1699-1720..

LATOUR, B. (2005) Reassembling the Social. Oxford University Press, Oxford, 2005.

Latour, B. (2007). "The Recall of Modernity: Anthropological Approaches." Cultural studies review.).

Law, J. (1991). A Sociology of Monsters: Essays on Power, Technology and Domination. Routledge.

Law, J. (2004) After Method: Mess in social science research. Routledge, London.

Layes, C. (1996) “The Rise and Fall of Development Theory”. Indiana University Press, Bloomington.

Levin, D. M. (1993). Modernity and the Hegemony of Vision. University of California Press.

Levine, JM. (1991). "Giambattista Vico and the Quarrel between the Ancients and the Moderns.” Journal of the History of Ideas 52(1):55-79.

Leyes, (1998) Rise and Fall of Development Theory. Indiana University Press

MacAuslan, I., e Riemenschneider, N. (2011). "Richer but Resented: What Do Cash Transfers Do to Social Relations?” IDS Bulletin 42(6):60-66.

Machado, L. (1999). “A Teoria Da Dependência Na América Latina.” Estudos avançados 13(35):199-215.

Mahtaney, P. (2007). India, China and Globalization. Palgrave Macmillan.

Mali, J. (1992). The Rehabilitation of Myth: Vico's New Science. Cambridge University Press.

Mallick, S. (2009). Macroeconomic Policy and Poverty Reduction in India. 
Mandelbrote, S. (1996). "History, Narrative, and Time." History of European ideas 22(5):337-50.

Mas, E. De, e Houck. J. K. (1971). "On the New Method of A New Science: A Study of Giambattista Vico Author.” Journal of the History of Ideas 32(1):85-94).

Mclure, R. (1994). The Philosophy of Time. edited by Michael Goldman.

Melville, Herman. 1851. Moby Dick.

Mignolo, W. (2003a) Historias locales/ diseños globales. Colonialidad, conocimientos subalternos y pensamiento fronterizo. Madrid: Akal 2003.

MIGNOLO, W. (2003b) The Darker Side of the Renaissance: literacy, territoriality ando colonization. Michigan: University of Michigan Press, 2003.

Mignolo, W. (org) (2001) Capitalismo e Geopolítica do Conhecimento. Buenos Aires, Ediciones del Signo.

Mignolo, W. D. (1996). "Espacios Geograficos Y Localizaciones Epistemologica: La Ratio Subalternización de Conocimientos.” Pensar (Mignolo).

Miner, R. C. (1998). “"Verum-Factum' and Practical Wisdom in the Early Writings of Giambattista Vico.” Journal of the History of Ideas 59(1):53-73

Monte, P. (2008) Exploração do Trabalho Infantil no Brasil: Consequências e Reflexões. Revista EconomiaA. v.9, n.3, p. 625-650, set/dez 2008

Murphy, J (2008) The World Bank and Global Managerialism. Routledge, London.

Narayanan, S. (2011) A Case for Reframing the Cash Transfer Debate in India. may 21, 2011 vol xlvi no 21 EPW Economic \& Political Weekly

NISBET 1982

Paine, T. (1974). AGRARIAN JUSTICE. Retrieved August 31, 2013 (http://schalkenbach.org/library/henry-george/grundskyld/pdf/p_agrarian-justice.pdf).

Panigrahi, D. N. 2004. India's Partition. Routledge.

Parfitt, T. e Sterling. L. 2002. The End of Development? Modernity, Post-Modernity and Development. Pluto Press.

Patnaik, P. (2014) The End of the Comission? Vol - XLIX No. 29, July 19, 2014 
Patnaik, U. (2006) Poverty and Neo-Liberalism In India. Based on Rao Bahadur Kale Memorial Lecture delivered at Gokhale Insitute of Politics and Economics, Pune, February 03, 2006. This version revised and expanded, December 2006.

Patnaik, U. e Moyo, S. (2011) The Agrarian Question in Neoliberal Era: Primitive Accumulation and the Peasentry. London, Pambazuka Press: 2011

Peet, R. e Hartwick, E. (2009) Theories of Development. New York: Gilford Press, 2009.

Penha, A. (2011) Relações Brasil-África e a Geopolítica do Altântico Sul. Salvador, EDUFBA: 2011.

Pereira, J. (2010) O Banco Mundial e a construção político-intelectual do "combate à pobreza”. Topoi, v. 11, n. 21, jul.-dez. 2010, p. 260-282

Piazzini S. C.E. (2003) "El tiempo situado: las temporalidades después del giro espacial", en Diego Herrera Gómez y Carlo Emilio Piazzini S. (edits.), (Des)territorialidades y (No)lugares. Procesos de configuración y transformación social del espacio. Medellín: Universidad de Antioquia, 2003.

Pieterse, J. N. (1998). "My Paradigm or Yours? Alternative Development, PostDevelopment, Reflexive Development." Development and Change 29(1998):343-73.

Pieterse, J. N. (2010). Development Theory. Sage.

Portes, A. (1997) Neoliberalism and the sociology of development. Population and Development Review, Vol. 23, No. 2 (June 1997), 229-259.

Portes, A. (2010). Economic Sociology: A Systematic Inquiry. Princeton University Press. Portes, Alejandro. (1997). "Neoliberalism and the Sociology of Development: Emerging Trends and Unanticipated Facts." Population and development review 23:229-59.

Portes, Alejandro. (2004). El Desarrollo Futuro de América Latina: Neoliberalismo, Clases Sociales Y Transnacionalismo. Edciciones Antropos.).

Quijano, A. (2000). “Colonialidad Del Poder Y Clasificación Social.” Journal of WorldSystems Research 2(6):342-82).

Quijano, A. (2006) Dom Quixote e os Moínhos de Vento na América Latina. Dossiê América Latina. Revista Estudos Avançados da USP. vol. 19 no. 55. São Paulo, 2006.

Quijano, A. (2007). "Des/colonialidad Del Poder: El Horizonte Alternativo." ... Democracia en la diversidad, Abya-Yala, ... 13(29):1-5. 
Ray, Christopher. (1991). Time, Space and Philosophy. Routledge. Retrieved October 26, 2013

Reid, B. (2013). "Exporting Social Policy from Latin America to the Philippines: Securitisation, Neoliberalism and Multilateral.” iippe.org.

Restrepo, E. e Rojas, A. (2010) Inflexión decolonial: fuentes, conceptos y cuestionamientos. Editorial Universidad del Cauca.

Ribeiro, G., Silva, K. e Barros, F. (2012) Global Flows Of Development Models. Laboratory for the Study of Globalization and Development. Final Report.

Ricoeur, P. (2000). "Narratividad, Fenomenología Y Hermenéutica." Anàlisi: quaderns de comunicació i cultura.

Ricoeur, P. (2004). Memory, History, Forgetting. University of Chicago Press. Retrieved November 18, 2013.

Ricoeur, Paul. (1984). Time and Narrative. University of Chicago Press.

Ricoeur, Paul. (1995). Tiempo E Narracion II. Siglo XXI Editores.

Ricoeur, Paul. (1996). Tiempo Y Narración III. Siglo XXI Editores.

Ricoeur, Paul. (2004). Tiempo Y Narración I. Siglo XXI Editores.

Rodrigues, D. F. (2010). "Cooperação Horizontal Sul-Sul: Arranjos de Concertação Política Entre a Índia , O Brasil E a África Do Sul.” Revista Brasileira de Política Internacional 53(1):45-66.

Rodrigues, R. (2008) Motivações Sociais Na Recontextualização Do Discurso Do Programa Bolsa Família. Dissertação de Mestrado. UFJF.

Rosa, M. (2014) Theories of the South: Limits and perspectives of an emergent movement in social sciences. Current Sociology 1-17

Sachs, W. (2010) The Development Dictionary: A Guide to Knowledge as Power. Zed Books, New York, 2010.

Samson, (2009) Social Cash Transfers and Pro-Poor Growth. OECD.

Santos, B. (1997) Pela Mão de Alice São Paulo: Cortez.

Santos, B. (2006). Conocer Desde El Sur: Para Una Cultura Política Emancipatoria. Fondo Editorial de la Facultad de Ciências Sociales. 
Santos, B. (2006a). Renovar La Teoría Crítica Y Reinventar La Emancipación Social: Encuentros En Buenos Aires. CLACSO.

Santos, B. (2006b) Conocer desde el Sur. Para una cultura política emancipadora. Parte Primera: En busca de un nuevo paradigma crítico. Lima: CIDES, 2006.

Santos, B. (2009a) Una Epistemología del Sur: La reinvención del conocimiento y la emancipación social. México: Siglo XXI Editores/ Clacso.

Santos, B. e Meneses, M. P. (Orgs.). (2009b) Epistemologia do Sul. Coimbra: Edições Almedina.

Santos, M. (1988). Metamorfoses Do Espaço Habitado. Hucitec, São Paulo.

Santos, M. (2006). A Natureza Do Espaço. Edusp, São Paulo.

Santos, T. Teoria da Dependência: Um Balanço Histórico. Texto publicado na página pessoal do autor. http://theotoniodossantos.blogspot.com.ar Acessado 12 de junho de 2012.

SCHLESENER, A. H. Hegemonia e Cultura: Gramsci. Curitiba: Editora UFPR, 1992.

Sen, A. (2005) Argumentative India. Penquin Books India.

Sen. A. (2010) Desenvolvimento como Liberdade. Companhia das Letras, São Paulo.

Sentos, M. (2008) Técnica, Espaço, tempo. Editora Usp, São Paulo.

SEWA. (2013) An experimental Cash Transfer Programme in Delhi. 2003

Sidney, K. Vishal, D. e El-Kathio, Z. E Costa, A. (2012) India's JSY cash transfer program for maternal health. Reproductive Health 2012, 9:2

Silva, J. G. Grossi, M e França, C. (2010) FOME ZERO A Experiência Brasileira. MDS.

Silveira, M. (2011) Desenvolvimento X Buen Vivir: Concepções De Natureza E Tensões Territoriais No Equador Plurinacional. Revista Geográfica de América Central Número Especial EGAL, 2011- Costa Rica II Semestre 2011 pp. 1-17

Sklair, L. (2005) Sociology of Progress. London: Routledge.

Soares, F. (2010) in: Ipea (2010) Bolsa Família 2003-2010: avanços e desafios Vol 1. Série Desenvolvimento

Soares, F. (2011) Brazil's Bolsa Família: A Review. Economic \& Political Weekly. May 21, 2011 vol xlvi no 21 
Soares, S. (2007) Programas de Transferência Condicionada de Renda no Brasil, Chile E México: Impactos Sobre a Desigualdade. Ipea.

Spence, T, King, J. e Marangos. J, (2006). "TWO ARGUMENTS FOR BASIC INCOME : THOMAS PAINE ( 1737-1809 ) AND THOMAS SPENCE ( 1750-1814 ) J. E. King.” 3086.

Spicker, P et alli. (2009) Pobreza: Un Glosario Internacional. Buenos Aires: Clacso, 2009.

Srivastan, R. (2012) History of Development Thought. Routledge India

SSC-UNDP. Framework of operational guidelines on United Nations support to SouthSouth and triangular cooperation. 2012

Standing, G. (2011) Cash Transfers: A Review Of The Issues In India. Unicef.

Stein, B. (2010) A History of India. London Blackwell.

Stokes, S. (2004). Mandates and Democracy: Neoliberalism by Surprise in Latin America. Cambridge University Press.

Sugiyama, N. B. (2011). "The Diffusion of Conditional Cash Transfer Programs in the Americas." Global Social Policy 11(2-3):250-78.

Suplicy, E. M. (2008) Renda de Cidadania: a saída é pela porta. São Paulo: Cortez, 2008. 5a ed. 390 p.

Swaminathan, (2008) Programmes to Protect the Hungry: Lessons from India. DESA Working Paper No. 70

Tarassiouk, A. (2007) Estado y desarrollo: Discurso del Banco Mundial y una visión alternativa. In: Repensar la teoría del desarrollo en un contexto de globalización. Homenaje a Celso Furtado. Vidal, Gregorio; Guillén R., Arturo.(comp). Enero 2007

Tessarolo, (2004) A Passagem Do Programa Comunidade Solidária Para O Programa Bolsa Família: Continuidades E Rupturas. CAOS - Revista Eletrônica de Ciências Sociais Número 16 - Março de 2011 Pág. 74 - 92.

TFDTS, 2011

Tripathi, A. (2012). "India-Brazil Strategic Engagement - Possibilities for the Future." Indian Foreign Affairs Journal 7(2):206-17.

Turner, B. S. (1990). Theories of Modernity and Postmodernity. Sage. 
Turner, S. e Risjord, M. (2007). Philosophy of Anthropology and Sociology. Elsevier.

UNDP. (2008). Poverty Reduction That Works: Experience of Scaling Up Development Success. UNDP.

UNRISD. (2009). Financing Social Policy: Mobilizing Resources for Social Development. Vaidyanathan, (1983). The Cambridge Economic History of India Vol. 2. Cambridge University Press.

Vico, Giambattista. 1948. The New Science. Cornell University Press.

VIEIRA, M. Relações Brasil - India. Porto Alegre, Editora UFRGS: 2009.

Wallerstein, I. (1983). Historical Capitalism. Verso.

Wallerstein, I. (1984). The Politics of the World-Economy. Cambridge University Press.

Wallerstein, I. (1996). Abrir Las Ciencias Sociales. Siglo XXI Editores.

Wallerstein, I. (2006). European Universalism: Rhetoric of Power. The New Press.

Wallerstein, I. (2011). The Modern World-System I: Capitalist Agriculture and the Origins of the European World-Economy in the Sixteenth Century. Academic Press.

Wan, G. (2008). Understanding Inequality and Poverty in China: Methods and Applications. Palgrave Macmillan.

White, H. (1975). Metahistory: The Historical Imagination in Nineteenth-Century Europe. The John Hopkins University Press.

Williamson, J. (2001) The Washington Consensus as Policy Prescription for Development. A lecture in the series "Practitioners of Development" delivered at the World Bank on January 13, 2004

Wood, R. E. (1986) From Marshall Plan to Debt Crisis. University of California Press

World Bank. (1991) Social Security Reforms and Social Safety Nets.

World Bank. (1991) World Development Report. 1991.

World Bank. (2001) World Development Report: Attacking Poverty: Opportunity, Empowerment, and Security. 2001

World Bank. (2003) World Bank Social Protection Strategy Paper: From Safety Net to Springboard.

World Bank. (2004) World Development Report: Making Services Work For Poor People. 
World Bank. (2006) Poverty and social impact analysis of reforms: lessons and examples from implementation. 2006

World Bank. (2006) World Development Report: Equity and Development.

World Bank. (2007) The Nuts and Bolts of Brazil’s Bolsa Família Program.

World Bank. (2009) Conditional Cash Transfers.

World Bank. (2011)Social Safety Nets: An Evaluation of World Bank Support, 20002010.

Yasbek, M. (2004) O Programa Fome Zero No Contexto Das Políticas Sociais Brasileiras São Paulo em Perspectiva,18(2):210044-112, 